\author{
UNIVERSIDADE DE SÃO PAULO \\ ESCOLA DE COMUNICAÇÕES E ARTES \\ PROGRAMA DE PÓS-GRADUAÇÃO EM CIÊNCIAS DA COMUNICAÇÃO
}

TISSIANA NOGUEIRA PEREIRA

\title{
NAVEGANDO COM A TELENOVELA? \\ Mediações, recepção e ficção televisiva em tempos transmídia
}




\author{
UNIVERSIDADE DE SÃO PAULO \\ ESCOLA DE COMUNICAÇÕES E ARTES \\ PROGRAMA DE PÓS-GRADUAÇÃO EM CIÊNCIAS DA COMUNICAÇÃO
}

TISSIANA NOGUEIRA PEREIRA

\title{
NAVEGANDO COM A TELENOVELA?
}

Mediações, recepção e ficção televisiva em tempos transmídia

Tese apresentada ao Programa de Pós-Graduação em Ciências da Comunicação, Área de Concentração Ciências da Comunicação, Linha de Pesquisa Comunicação, redes e linguagens: objetos teóricos e empíricos, da Escola de Comunicações e Artes da Universidade de São Paulo, como exigência para a obtenção do Título de Doutora em Ciências da Comunicação.

Orientação: Profa. Dra. Maria Immacolata Vassallo de Lopes 
Autorizo a reprodução e divulgação total ou parcial deste trabalho, por qualquer meio convencional ou eletrônico, para fins de estudo e pesquisa, desde que citada a fonte.

Catalogação na Publicação

Serviço de Biblioteca e Documentação

Escola de Comunicações e Artes da Universidade de São Paulo

Dados inseridos pelo(a) autor(a)

Pereira, Tissiana Nogueira

Navegando com a telenovela? Mediações, recepção e ficção

televisiva em tempos transmídia / Tissiana Nogueira Pereira

; orientadora, Maria Immacolata Vassallo de Lopes. -- São

Paulo, 2020 .

$312 \mathrm{p}$.

Tese (Doutorado) - Programa de Pós-Graduação em Ciências da Comunicação - Escola de Comunicações e Artes / Universidade

de São Paulo.

Bibliografia

Versão original

1. Telenovela 2. Recepção 3. Mapa das Mediações 4.

Transmídia 5. Classe Social I. de Lopes, Maria Immacolata

Vassallo II. Título.

CDD 21.ed. - 302.2

Elaborado por Alessandra Vieira Canholi Maldonado - CRB-8/6194 


\section{Tissiana Nogueira Pereira}

Navegando com a telenovela? Mediações, recepção e ficção televisiva em tempos transmídia

Banca examinadora

Presidente:

Profa. Dra. Maria Immacolata Vassallo de Lopes

Membros:

São Paulo,

de

de 2020 . 
Dedico esta tese a todos que, assim como eu, resistem e ainda acreditam que a Educação $e$ Ciência podem mudar o Brasil. 


\section{AGRADECIMENTOS}

À minha mãe, por tudo o que ela representa. Por ter me feito respirar pesquisa desde muito cedo. Por estar sempre presente, por ser meu exemplo, meu incentivo, meu alicerce e a razão pela qual eu tento ser uma pessoa melhor a cada dia;

ao GZ, pelo lugar importante que ocupa em minha vida, o teu apoio e dedicação foram, são e sempre serão fundamentais;

a toda minha família, pelo suporte e incentivo que permitiram com que eu me dedicasse, com tranquilidade e de forma exclusiva, ao Doutorado;

ao Yaasin, que aterrizou em São Paulo no meio dessa “ longa viagem” que é o Doutorado e que, sabendo como as turbulências me fazem mal, segurou forte na minha mão até que esta "viagem" acabasse. Seguimos ao próximo destino.

aos meus informantes, por terem aberto as portas de suas casas e me recebido em seus sofás. Se isso não tivesse acontecido, esta pesquisa não existiria;

à Professora Immacolata, pela oportunidade de ser sua orientanda e por todos os ensinamentos ao longo desses quatro anos de convivência intensa;

aos colegas do CETVN, pela amizade, pela parceria, pela solidariedade e por me surpreenderem positivamente, mostrando-me, no dia a dia, que, sim, existe amor em São Paulo. Rafa Crema, Anézio, Eduardo, Vital, Letícia, Alisson, Gustavo e todos os outros bolsistas que passaram pelo Centro ao longo desses quatro anos, Clarice, Fernanda, Lígia, Larissa, Dani, Andreza, Lucas e Mari;

à Mari, mais uma vez, minha amiga e companheira. Que, em meio a Martín-Barbero, mapas, Maxdqa, esfirras, chocolates, cafés, choros e risos aqui em casa e incontáveis áudios pelo WhatsApp, tornou esse processo menos solitário e muito mais leve;

ao Lucas, meu Xidieh querido, quantas risadas, memes, desabafos, ensinamentos... te ter por perto me faz tão bem;

aos meus amigos e ex-colegas de UFSM, os "Lindos da Pesquisa," que, mesmo de longe, sempre estiveram presentes;

aos funcionários e professores do Programa de Pós-Graduação de Comunicação da ECA/USP, pela paciência, pela gentileza e pelos ensinamentos fundamentais ao longo desse processo de produção de conhecimento;

à CAPES, pelo auxílio financeiro por meio da bolsa de estudo para a realização da pesquisa;

aos Professores da banca, por aceitarem participar da comissão examinadora deste trabalho. 
"Ver con los otros, entender con los otros, exige dejarse tocar por los otros; cuando nuestra visión ha cambiado, significa nunca más ver lo mismo" (MARTÍN-BARBERO e CORONA, 2017, p. 140). 


\section{RESUMO:}

Esta tese é uma releitura e atualização teórico- metodológica do clássico livro de recepção Vivendo com a telenovela- mediações, recepção, teleficcionalidade, publicado por Lopes, Borelli e Resende, em 2002. Investigamos como a recepção da telenovela tem sido reconfigurada devido ao contexto comunicacional atual das novas mídias em que as tecnologias estão criando um ambiente transmídia já incorporado no cotidiano comum das pessoas e nas mídias sociais. Isto foi feito a partir de um estudo de recepção com amostra qualitativa composta por duas familias de diferentes classes sociais (uma de classe média baixa e uma de classe média alta). O corpus da tese é composto por todos os capítulos da telenovela $O$ Sétimo Guardião (Globo, 21h), de Aguinaldo Silva, disponibilizados e acessados na plataforma Globoplay. É um tempo diferente daquele em que o livro foi escrito e publicado, com 18 anos de distância. Por isso, o tema é relevante por ser contemporâneo e problematizar um possível empoderamento do receptor dentro da nova ecologia comunicacional. A pesquisa de releitura tem como eixo teórico e metodológico a Teoria Barberiana da Comunicação de Martín-Barbero $(1987,2017)$ e de classe social a partir de Pierre Bourdieu (2007), como no livro, acrescida pelos estudos sobre transmídia (JENKINS, 2006, 2009) para problematizar a nova ambiência comunicativa possibilitada pelas novas mídias, fluxos e plataformas. A tese tem na exploração multimetodológica e na adequação dos Mapas das Mediações (MARTÍN-BARBERO, 1987, 2009, 2016, 2017) os dois eixos a partir dos quais se investiga a recepção de dentro do contexto transmídia caracterizado por mutações na produção e na recepção de conteúdos comunicacionais na contemporaneidade. Entre os principais resultados, estão o fato de que a classe social continua sendo mediação estruturante na recepção da telenovela mesmo que com algumas resignificações geradas pelas novas tecnologias e pelo novo ecossistema digital da contemporaneidade. Além do que a recepção da telenovela foi reconfigurada desde o estudo de 2002, justamente devido à presença das novas mídias no espaço doméstico. A intensidade dos usos e apropriações destas novas telas varia de acordo com a geração dos informantes.

Palavras-chave: Telenovela. Recepção. Mapa das mediações. Transmídia. Classe social 


\section{ABSTRACT:}

This thesis is a re-reading and theoretical-methodological update of the classic reception book, Vivendo com a telenovela- mediações, recepção, teleficcionalidade, published by Lopes, Borelli, and Resende in 2002. We investigated how the reception of the telenovela has been reconfigured due to the current communicational context of new media, in which technologies create a transmedia environment already incorporated into people's everyday lives and social media. For this, we did a reception study with a qualitative sample composed of two families from different social classes (one from the lower-middle class and another from the upper-middle class). The thesis corpus consists of all the chapters of the telenovela $O$ Sétimo Guardião (Globo, 21h) by Aguinaldo Silva, available and accessed on the Globoplay platform. We highlight that now is a different time, if we consider that of the book was written and published 18 years ago. Therefore, the subject of this thesis is relevant and contemporary, problematizing the possible receptor empowerment within the new communicational ecology. The rereading research has as its theoretical and methodological axis the Barberian Theory of Communication by Martín-Barbero $(1987,2017)$ and the social class by Pierre Bourdieu (2007), as in the book, added by studies on transmedia (JENKINS, 2006, 2009) to problematize the new communicative environment made possible by new media, flows, and platforms. The two axes of this thesis are the multimethodological exploration and the adequacy of the Mediation Maps (MARTÍN-BARBERO, 1987, 2009, 2016, 2017) from which it is investigated the reception within the transmedia context, characterized by mutations in the production and the reception of contemporary communicational content. Among the main results, the social class continues to be a structuring mediation in the reception of the telenovela, even with some reframes generated by the new technologies and the new digital ecosystem of contemporary times. In addition, the telenovela reception has been reconfigured since the 2002 study due to the presence of new media in the domestic space. The intensity of the uses and appropriations of these new screens varies according to the generation of the informants.

Keywords: Telenovela. Reception. Mediation maps. Transmedia. Social class 


\section{LISTA DE FIGURAS}

Figura 1: Modelo Metodológico de Pesquisa

Figura 2: Primeiro Mapa das Mediações Culturais da Comunicação - 1987

Figura 3: Segundo Mapa Teórico-Metodológico das Mediações Comunicativas da Cultura - 1998

Figura 4: Terceiro Mapa Teórico-Metodológico das Mediações: Mutações 71 Comunicativas e Culturais - 2010

Figura 5: Quarto Mapa Teórico-Metodológico - Mutações Culturais e Comunicativas 77 Contemporâneas - 2017

$\begin{array}{ll}\text { Figura 6: Fusão de todos os Mapas de Martín-Barbero } & 78\end{array}$

Figura 7: Posse de smartphone no Brasil ao longo dos anos $\quad 85$

Figura 8: Formas de acesso à internet no Brasil $\quad 86$

Figura 9: Consumo médio de televisão entre os telespectadores brasileiros $\quad 87$

$\begin{array}{ll}\text { Figura 10: Tipologia de fãs } & 97\end{array}$

Figura 11: Estratégias e Conteúdos Transmídia 99

Figura 12: Gráfico de Índice de Gini da distribuição do rendimento domiciliar per capita - 121 Brasil: 2012-2018

Figura 13: Evolução das classes em porcentagem da população 135

Figura 14: Evolução das classes emmilhões de pessoas 135

Figura 15: Capa do livro Vivendo com a telenovela: mediações, recepção, 145 teleficcionalidade (LOPES, BORELLI e RESENDE, 2002)

Figura 16: Diagrama da mobilização dos mapas na pesquisa empírica 152

Figura 17: Protocolo Multimetodológico da pesquisa empírica 154

Figura 18: Foto da interface do software Maxda Analytics Pro 2018 com nossa pesquisa 164

Figura 19: Diagrama da Família $1 \quad 176$

Figura 20: Sala com a principal televisão da casa da Família $1 \quad 178$

Figura 21: Diagrama da Família $2 \quad 186$

Figura 22: Sala com a principal televisão da cas a da Família $2 \quad 189$

Figura 23: Cidade cenográfica de Serro Azul- O Sétimo Guardião 194

Figura 24: Fonte cenográfica - O Sétimo Guardião 194

$\begin{array}{ll}\text { Figura 25: Frame da cena em que Milú aparece para Mirtes } & 203\end{array}$

$\begin{array}{ll}\text { Figura 26: Frame da cena da morte de Gabriel } & 204\end{array}$

$\begin{array}{ll}\text { Figura 27: Frame com a cena da morte de Egídio } & 205\end{array}$ 
Figura 28: Frame da cena da morte de Feliciano 206

Figura 29: Frame da cena da morte do Delegado $\quad 207$

Figura 30: Frame da cena em que Luz aceita ser guardiã $\quad 208$

Figura 31: Frame da cena do acidente de Gabriel 209

Figura 32: Nuvem de palavras TVN-R Família 1

Figura 33: Frame de León se transformando em homem - sequência 1

Figura 34: Frame de León se transformando em homem - sequência $2 \quad 213$

Figura 35: Frame de Mirtes destratando alguém $\quad 214$

Figura 36: Frame de Bebeto dançando afrontando Nicolau $\quad 216$

Figura 37: Frame de Rivalda tendo "ataques de machis mo" $\quad 217$

Figura 38: Frame de Adamastor no bordel/pensão 19

Figura 39: Frame sobre mistério assassinatos -início de tudo 220

$\begin{array}{ll}\text { Figura 40: Frame sobre assassinatos - morte do Delegado } & 221\end{array}$

Figura 41: Frame sobre mistérios sobre assassinatos - morte do Aranha 222

Figura 42: Nuvem de palavras TVN-R Família $2 \quad 223$

Figura 43: Assistência de capítulos telenovela no telefone celular 239

Figura 44: Assistência da telenovela na televisão $\quad 244$

Figura 45: Exemplo de atividades nas redes sociais - Ana 252

Figura 46: Exemplo de atividades nas redes sociais - Pâmela $\quad 252$

Figura 47: Exemplo de atividades nas redes sociais - Vinícius 253

Figura 48: Retrato do documento sobre a telenovela - Ana $\quad 254$

Figura 49: Retrato do documento sobre a telenovela - Pâmela 255

Figura 50: Retrato do documento sobre a telenovela - Vinícius $\quad 255$

Figura 51: Exemplo de atividades nas redes sociais - Marina $\quad 260$

Figura 52: Exemplo de atividades nas redes sociais - Edna $\quad 260$

Figura 53: Exemplo de atividades nas redes sociais - Edna $\quad 261$

Figura 54: Retrato do documento sobre a telenovela - Marina 262

Figura 55: Retrato do documento sobre a telenovela - Edna 262 


\section{LISTA DE QUADROS}

Quadro 1- Teses e dissertações defendidas sobre recepção de telenovela e 110 internet/convergência/transmídia a partir de 2010

Quadro 2: Perfil dos integrantes da Família 1 175

Quadro 3: Perfil dos integrantes da Família 2 186 


\section{LISTA DE ANEXOS}

Anexo A - Clipping com notícias e conteúdos sobre $O$ Sétimo Guardião 293

Anexo B - Instrumento de entrevista de Gênero Ficcional 301

$\begin{array}{ll}\text { Anexo C - Instrumento de entrevista de História de Vida } & 304\end{array}$

Anexo D - Instrumento de entrevista de História de Vida Cultural 306

Anexo E - Questionário do consumo 307 


\section{SUMÁRIO}

INTRODUÇÃO

PARTE I: A CONSTRUÇÃO TEÓRICO-METODOLÓGICA DA PESQUISA 26

Capítulo 1: O objeto de pesquisa: a telenovela brasileira 27

1.1 A televisão: conceito e contínua relevância 27

1.2. A telenovela brasileira: apontamentos e especificidades da narrativa da 30 nação

Capítulo 2: A Teoria Barberiana da Comunicação $\quad 47$

2.1. Jesús Martín-Barbero: notas sobre o cartógrafo da complexidade 47

2.2 Os Mapas das Mediações: do calafrio epistemológico às mutações 56 culturais

2.2.1 Os mapas teórico-metodológicos das mediações $\quad 60$

Capítulo 3: A era transmídia e a convergência midiática na ficção televisiva 80

$\begin{array}{lr}\text { 3.1. A Cultura da Convergência } & 80\end{array}$

$\begin{array}{ll}3.1 .1 \text { A convergência e a ficção televisiva } & 81\end{array}$

$\begin{array}{ll}3.2 \text { A transmídia e a ficção televisiva } & 88\end{array}$

3.3 A recepção transmídia de telenovela. 95

Capítulo 4: A classe social como mediação estruturante 118

$\begin{array}{lr}\text { 4.1. A importância do conceito } & 118\end{array}$

4.2 A classe social a partir de Pierre Bourdieu $\quad 126$

4.2.1 A distinção entre as classes sociais $\quad 130$

4.3 As classes médias no Brasil: sobre quem estamos falando? 134

4.3. 1 Nova classe média? Não, nova classe trabalhadora 138

Capítulo 5: A metodologia na pesquisa empírica 144

$\begin{array}{ll}\text { 5.1. Vivendo com a telenovela: o livro inspiração } & 144\end{array}$

5.2 Premissas multimetodológicas $\quad 150$

5.3 Protocolo metodológico da pesquisa 152

$\begin{array}{ll}\text { 5.3.1 Composição da amostra } & 164\end{array}$

$\begin{array}{ll}\text { 5.3.2 O corpus da pesquisa } & 167\end{array}$

5.4 Os percursos e percalços da pesquisa empírica: uma reflexão 167

PARTE II: NAVEGANDO COM A TELENOVELA $\quad 174$

$\begin{array}{ll}\text { Capítulo 6: Nosso universo de pesquisa } & 175\end{array}$

$\begin{array}{ll}\text { 6.1. A realidade das famílias } & 175\end{array}$

6.2. A telenovela O Sétimo Guardião 192

$\begin{array}{ll}\text { 6.3. A telenovela reeditada (TVN-R) } & 201\end{array}$

Capítulo 7: As mediações na recepção da telenovela 224

7.1. Temporalidades: a socialidade no cotidiano familiar 224

7.2. Espacialidades: a ritualidade na assistência da telenovela 234

7.3. Sensorialidades: as identidades e cidadanias e os receptores de 244 telenovela

7.4. Tecnicidades: narrativas, redes e o gênero ficcional 250

CONSIDERAÇÕES FINAIS $\quad 266$

REFERÊNCIAS $\quad 274$

ANEXOS 293 


\section{'INTRODUÇÃO}

Esta tese é uma pesquisa empírica, de caráter qualitativo e transdisciplinar, ou seja, uma reconstrução da realidade que, para se tornar objeto científico, precisa ser constituída por operações de caráter teórico em função do fenômeno comunicativo que pretendemos estudar (LOPES, 2014). Nossa concepção de investigação segue a percepção de Lopes (Ibdem) de que a pesquisa é um campo dinâmico múltiplo composto por níveis e fases que se articulam dialeticamente e que se configura como estrutura (apresenta articulação vertical entre níveis epistemológicos, teóricos e metódicos) e como processo (realizada mediante uma articulação horizontal entre fases da investigação como a definição do objeto, a observação, a descrição e, por fim, a interpretação). Como estrutura, a pesquisa está situada em um eixo paradigmático do discurso científico e, como processo, localizada no eixo sintagmático. Isto está explicitado no Modelo Metodológico elaborado pela autora:

\section{Figura 1: Modelo Metodológico de Pesquisa}

PARADIGMA

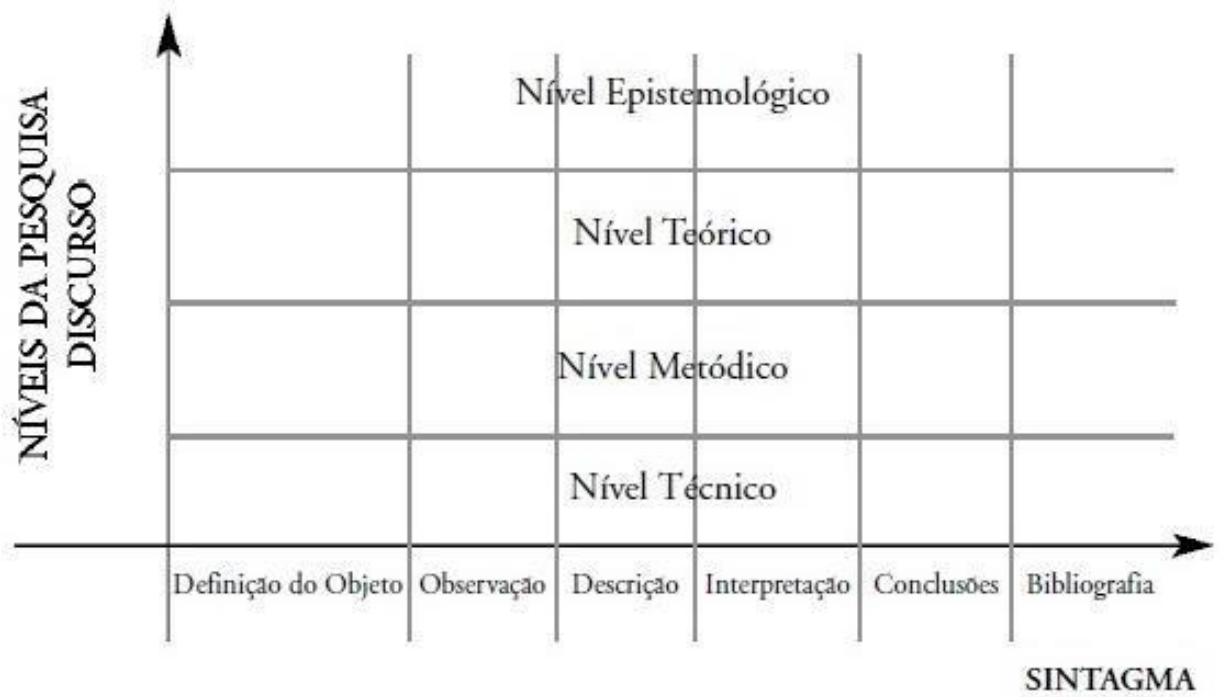

FASES DA PESQUISA

PRÁTICA

Fonte: Lopes (2014, p. 156)

O Modelo é calcado em condições concretas da prática científica em Comunicação e está baseado em dois princípios fundamentais: o primeiro deles é que não se faz uma reflexão metodológica de maneira abstrata, já que o saber de uma 
disciplina não pode ser deslocado de sua implementação na pesquisa; o segundo é de que esta reflexão é necessária para criar "uma atitude consciente e crítica" (LOPES, 2014, p. 92, grifos da autora) do investigador quanto ao que realiza na sua pesquisa. Desta forma, "o campo de pesquisa não é redutível a uma sequência de operações, de procedimentos necessários e imutáveis de normas rigidamente codificadas" (Ibdem, p. 98), o que converteria a metodologia em um receituário, em algo burocrático.

Por isso, durante toda nossa pesquisa, procuramos não perder a reflexividade epistemológica, principalmente na fase de observação. E tampouco tentamos naturalizar os métodos e as técnicas de observação. Desta forma, a pesquisa empírica constitui-se no rompimento epistemológico entre o senso comum e a ciência (BACHELARD, 1972), sendo que o princípio epistemológico fundamental para o ajustamento entre o sujeito e o objeto de pesquisa é a explicitação do lugar de fala do pesquisador (LOPES, 2004), pois, desta maneira, suas opções epistemológicas, metodológicas, teóricas e operacionais podem ser compreendidas com maior clareza. As escolhas feitas durante o percurso de uma pesquisa não são neutras e por isso devem ser justificadas:

a justificativa já deveria trazer a marca do compromisso do investigador com os problemas que necessitam ser pesquisados, com as perguntas importantes a ser feitas hoje, aqui e agora. São as opções sobre quais temas pesquisar que devem ser as mais conscientes possíveis, declaradamente assumidas (LOPES e ROMANCINI, 2014, p. 137).

Dito isto, esta tese é uma releitura e atualização teórico- metodológica do clássico livro de recepção: Vivendo com a telenovela- mediações, recepção, teleficcionalidade, publicado por Lopes, Borelli e Resende, em 2002. Tal pesquisa foi sobre a recepção da telenovela por quatro familias de diferentes classes sociais por meio de uma proposta de exploração multimetodológica e utilizando a perspectiva das mediações de Martín-Barbero (1987). E, segundo o autor, a pesquisa contribuiu:

[...] como nenhuma outra anteriormente fez, para desenvolver e concretizar esta perspectiva teórica: no esforço para traduzi-la em linguagem metodológica, aprofunda e esclarece tanto o desafio epistemológico quanto seu sentido e alcance políticos (MARTÍNBARBERO, 2002b, p. 18, grifo do autor). 
A intenção não foi reproduzir a pesquisa de 18 anos atrás, mas avançar, especialmente com as questões transmídia, visto que investigamos como a recepção da telenovela tem sido reconfigurada devido ao contexto comunicacional atual das novas mídias em que as tecnologias estão criando um ambiente transmídia já incorporado no cotidiano comum das pessoas e nas mídias sociais. Afinal:

[...] torna-se imprescindível ajustar o foco dos "television studies" com o presente da "sociedade de rede" (CASTELLS) e sua "ecologia dos meios" (POSTMAN). Nela, é possível destacar, em princípio, dois momentos nas relações da audiência com a televisão: antes e após a entrada da participação do receptor nos processos que incentivam a transmidiação e a interatividade (LOPES e OROZCO GÓMEZ, 2014b, p.13, grifos da autora).

Filiamo-nos aos estudos de Comunicação que consideram a correlação entre a cultura e a sociedade contemporânea, sendo a cultura entendida como "significados e práticas que move e constitui a vida social" (ESCOSTEGUY, 2010, p.26). Reconhecemos ainda a relação recíproca entre a cultura e a comunicação, aqui entendida como um processo complexo e intermitente que envolve a produção, a mensagem, a recepção e o consumo. Tais estudos dessencializaram a cultura e têm preocupação com a ação social, produzindo "uma teoria engajada nas diferenças culturais" (Ibdem, p. 39). O principal interesse é ver e investigar os cruzamentos entre as estruturas sociais e as formas e práticas culturais, por isso, a análise dos meios de comunicação é feita problematizando o poder e a hegemonia e sua relação com a cultura e os processos políticos. Nesta perspectiva, pesquisar a interação entre comunicação e cultura exige uma aproximação antropológica, "pois o cotidiano tem valor histórico para compreender a sociedade" (JACKS e ESCOSTEGUY, 2005, p. 66).

Então, a pesquisa tem como eixo teórico principal os estudos de cultura latinoamericanos, partindo especialmente do Paradigma da Comunicação de Jesús MartínBarbero que, por sua completude, complexidade e contemporaneidade, foi denominado por Lopes (2018) de Teoria Barberiana da Comunicação. A partir disto, trabalhamos com os Mapas das Mediações elaborados por Martín- Barbero (1987,1998, 2010, 2017) como subsídio teórico, metodológico e epistemológico para observar a recepção da telenovela na atualidade. Propusemo-nos a mobilizar os mapas conforme a demanda exigida pela nossa pesquisa, visto que eles são abertos e permitem essa articulação. Além do mais, trabalhar com eles em sua totalidade nos pareceu demasiado $\mathrm{e}$ 
desnecessário, tendo em vista que esta pesquisa tem limites de tempo e espaço que devem ser respeitados.

O pensamento do autor "[...] espanhol que se fez latino-americano -, ao qual a pesquisa em comunicação no Brasil, particularmente, é tão devedora" (LOPES e KUNSCH et al., 8) é adequado para a nossa pesquisa, porque supre a demanda da nova ecologia comunicacional. Faz refletir sobre todo o processo comunicativo, já que leva em consideração todos os aspectos e fluxos que envolvem toda a cadeia comunicacional, tanto na produção quanto na recepção e os espaços dialéticos que os envolvem:

Como é possível compreender de modo alternativo as complexidades de nossas vidas em meio a redes sociais e digitais? Como já insistia Martín-Barbero no ano de 1987, antecipando em três décadas nossas necessidades atuais (quando todos os investigadores estão buscando novos recursos para analisar uma realidade caprichosamente mutável): "não se trata de 'carnavalizar' a teoria [...] mas aceitar que os tempos não favorecem a síntese, que a razão nos permite apenas sentir [...] que existem zonas na realidade mais próxima que ainda estão inexploradas" (MARTÍN-BARBERO, 1987, p. 246, grifo meu). Nas palavras do grande filósofo e pensador francês Henri Lefebvre, Martín-Barbero nos ofereceu em seu livro um novo mapa para "tornar estranho o familiar" e nos facilitar a sua compreensão a partir de uma nova perspectiva (COULDRY, 2018, p. 37-38).

Aliado ao pensamento barberiano e de todos os outros autores que estudam a Comunicação a partir de sua concepção, apoiamo-nos ainda nos estudos sobre transmídia e cultura da convergência (JENKINS, 2009), uma vez que refletem sobre a nova ambiência comunicativa possibilitada pelas novas mídias, fluxos e plataformas e as novas mídias causaram e ainda causam enormes transformações na sociedade (Ibdem). Além do mais, versam sobre a ampliação das sociabilidades, já que as mudanças tecnológicas e culturais de circulação da mídia na contemporaneidade proporcionam a construção de sociabilidades também midiáticas. Estas sociabilidades são relacionadas aos artefatos culturais que fazem as pessoas estarem/viverem cada vez mais conectadas às redes, afetando, assim, as relações sociais e impondo outros sentidos ao consumo e à recepção midiática.

Estudamos a recepção da telenovela em tempos de transmídia e convergência, atentando para o fato de que essa nova ambiência mudou as lógicas produtivas, 
proporcionando uma dinâmica mais fluida e veloz na propagação de informações e conteúdos (DEPEXE, 2015) e empoderando o receptor com diversas possibilidades de produção, distribuição, fruição, apropriação e (re) elaboração de sentido dos conteúdos midiáticos.

A demanda imposta por essa nova configuração do ecossistema midiático fez com que, no Brasil, alguns pesquisadores voltassem o olhar para o tensionamento da recepção de telenovela e internet/convergência/transmídia. Mas, ainda sim, estas pesquisas são recentes e escassas no país, pois a maioria das investigações são acerca deste ambiente, mas sobre séries, e, essencialmente as estrangeiras, como as americanas. De 2010 até agora, das 254 teses e dissertações defendidas em programas de PósGraduação brasileiros sobre ficção televisiva, apenas 13 são sobre o nosso objeto, a recepção da telenovela em tempos de internet/convergência/transmídia. Fora isso, as investigações acerca do tema são majoritariamente desenvolvidas por algumas equipes da rede Obitel Brasil, na Coleção Teledramaturgia, ou então, em pesquisas individuais ou coletivas de pesquisadores membros da rede. Portanto, acreditamos que, por ser um tema contemporâneo e pouco estudado, tem relevância e deve ser olhado com mais atenção pelos acadêmicos.

Indispensável esclarecer que, mesmo com o aumento do consumo da internet e com a possibilidade de diferentes usos e apropriações por parte dos brasileiros, acrescentado a toda a diversidade ofertada pelos novos produtos como os canais a cabo e plataformas digitais on demand, a televisão divide sim espaço, mas continua soberana perante todas as outras mídias no país. E, na programação televisiva, cerca de $80 \%$ da produção ficcional brasileira é do formato telenovela, em sua maioria produzida e exibida pela Globo, líder de audiência no segmento (LOPES e MUNGIOLI et al., 2014) e reconhecidas mundialmente pelo seu "padrão de qualidade". A telenovela brasileira é também um dos produtos comunicacionais que melhor possibilitam a análise da relação cultura, hegemonia e política, pois "é dos raros textos consumidos por cidadãos pertencentes às mais diversas classes sociais, um repertório privilegiado para medir diferenças" (HAMBURGUER, 2005, p.73). Também atua como "narrativa da nação" e "recurso comunicativo" capaz de problematizar temáticas amplas em tramas pontuais, sugerindo a fusão dos domínios do público e do privado (LOPES, 2009). Estudamos a telenovela das 21 horas, antigamente chamada de telenovela das 20 horas (ia ao ar nesse horário) porque é a mais assistida até hoje: "a novela das oito é o programa que por 
maior período de tempo na história da televisão no Brasil mantém o mais alto índice de audiência e a maior dispersão de audiência entre as diferentes classes sociais" (LEAL, 1986, p. 12-13).

Investigamos a recepção da telenovela na atualidade sob a luz da classe social porque acreditamos que esta contribui para como os sujeitos vão ler, ver, usar, se apropriar e interpretar as mensagens midiáticas. Os estudos que situem a classe social dos receptores contribuem para a compreensão destas diferentes leituras midiáticas (MORLEY, 1996). Entendemos a classe social a partir de Bourdieu (2007) em que a visão de mundo que os agentes têm depende da sua posição no espaço social e do volume global de capital que possuem, determinando, assim, o seu estilo de vida.

Mas, na Comunicação há um certo desdém perante as desigualdades objetivas na vida dos sujeitos (FREIRE FILHO, 2007). Além disso, Grohmann (2016, p. 321, grifo do autor), em sua pesquisa de doutorado sobre o modo como o conceito é trabalhado no campo comunicacional no país, constatou que

[...] alguns trabalhos, a 'classe' aparece de maneira somente lateral, como ilustração. Foi também comum encontrar uma falta de reflexividade teórica, metodológica e conceitual em relação ao conceito, que podemos considerar, em certa medida, banalizado ou pouco aprofundado, como adorno, como dizendo para não-dizer.

Ainda sobre a necessidade das reflexões acerca de classe social, Sodré (2012) afirma que o prestígio do campo da Comunicação não advém da objetividade do conhecimento que é gerado, e sim da produção de valores sociais, políticos e culturais. Afinal, não é "só porque os presidentes de empresa hoje podem usar tênis, ouvir Rage Against the Machine e implorar a seus empregados para os chamarem de "fofos"" (EAGLETON, 2012, p. 134, grifo do autor), ou então porque, em algum momento, as classes trabalhadoras têm maior poder de compra que a classe social e, principalmente, as distinções de classe, desapareceram. Ademais, em uma pesquisa, classificar os agentes conforme sua classe social não é hierarquizar, muito menos colocar em voga a qualidade e os valores dos sujeitos, mas refletir sobre a posição que eles ocupam em uma estrutura social capitalista (SIFUENTES, 2014). E sobretudo, em uma sociedade como a brasileira, que "[...] se caracteriza pela extrema concentração da riqueza e pela desigualdade na distribuição de renda" (RONSINI, 2007, p.23).

Isto posto, em nossa pesquisa, examinamos se a classe social à qual pertencem 
continua estruturante nos usos e apropriações que os receptores fazem da telenovela em tempos de transmídia. No livro inspiração, a classe social também foi observada para investigar a recepção da telenovela, mas, aqui, o que pretendemos fazer foi avançar, não só pelo fato de que estamos analisando a recepção frente a um novo ecossistema comunicacional, mas também porque vimos a necessidade de expandir a classificação de classe feita na pesquisa de 2002, em que, em termos empíricos, era o bairro o determinante para colocar os receptores como pertencentes a uma classe. Concordamos que o local onde vivem diz muito sobre o estilo de vida e, por conseguinte, sobre sua classe, mas quisemos aqui problematizar outras questões que fazem um agente pertencer ou não a uma classe social. Além disso, trouxemos uma discussão sobre a nova classe média, denominação que ainda não existia quando foi realizada a pesquisa de Lopes, Borelli e Resende (2002).

Para isto, nossa pesquisa é de exploração multimetodológica que, além de transpor, readapta e atualiza o que foi realizado na pesquisa de 2002 de acordo com a contemporaneidade e com o nosso olhar. Portanto, nossa proposta atravessa todos os níveis da pesquisa: do epistemológico -teórico - através da Teoria Barberiana da Comunicação, por meio dos Mapas das Mediações (investigaremos a recepção analisando as mediações: temporalidades, narrativas, tecnicidades, redes, espacialidades, cidadanias, sensorialidades, identidades, sendo a classe social mediação estruturante), passando pelos paradigmas de classe social e da cultura da convergência chegando até o nível técnico-empírico através do modelo multimetodológico das mediações em que elaboramos um protocolo multimetodológico da pesquisa empírica que combina variadas técnicas de coleta e análise. Avançamos também em relação à pesquisa inspiração no uso de um software para auxiliar na tabulação dos dados coletados, pois utilizamos o programa Maxqda Analytics Pro 2018 com o intuito de explorar as inúmeras possibilidades proporcionadas por ele na nossa investigação e ainda contribuir para investigações futuras que queiram o auxilio de um programa de computador em suas pesquisas qualitativas.

A amostra da pesquisa é composta por duas famílias de diferentes classes sociais, uma de classe popular (classe média baixa) e outra de classe alta (classe média alta), classificadas empiricamente a partir dos critérios de Quadros, Gimenez e Antunes (2013). A importância de investigarmos a recepção sob a ótica da família se justifica porque ela é a unidade básica, espaço social, cultural e de mediação do que é visto nas 
telenovelas. E ainda, porque a telenovela é uma história de familias e relações familiares, assistida, comentada e (re) interpretadada, majoritariamente, no núcleo familiar, no universo doméstico dos receptores (LEAL, 1986).

O corpus é composto por todos os 161 capítulos da telenovela das 21 horas $O$ Sétimo Guardião (Globo, 2018-2019) e por um corpus menor composto pelas cenas escolhidas pelos receptores como as mais marcantes da telenovela, o que nós chamamos de telenovela reeditada (TVN-R). Além disso, também faz parte do corpus da pesquisa a sinopse da telenovela disponibilizada pelo Gshow do site Globo.com e um clipping com notícias e conteúdos sobre a trama coletados pela autora com o objetivo de complementar a análise acerca das questões de produção da telenovela.

Não podemos deixar de ressaltar que a televisão, sempre fez parte da vida da pesquisadora. No âmbito pessoal, durante as assistências dos mais variados programas em familia desde a infância, e, principalmente a telenovela tem lugar importante, pois, para além do gosto pelo formato, tem um valor afetivo despertado pela memória, quando, por exemplo, remete a uma das avós da pesquisadora, noveleira de plantão, que falava das personagens das tramas que estavam no ar como se fossem reais, incluindo-as nas conversações do dia a dia. $\mathrm{O}$ que, ironicamente, causava indignação ao avô, que não entendia como a esposa trazia essas personagens para as nossas rodas de conversa, especialmente, no momento da refeição. $\mathrm{Na}$ esfera profissional, a televisão também sempre esteve presente, na faculdade e na carreira como jornalista, e por isso, a opção por estudar este meio de comunicação como pesquisadora. Ser pesquisadora do Centro de Estudos de Telenovela (CETVN) da Escola de Comunicações e Artes da Universidade de São Paulo e do Observatório Iberoamericano de Ficção Televisiva (Obitel) influenciou também na escolha deste objeto. Estudar o cotidiano das pessoas e o modo como são representadas e abordadas pela telenovela, além de entender a sua construção de mundo e de si a partir da relação com a mídia, especialmente em tempos transmídia, é a principal razão da escolha desse objeto de estudo. Assim, a pesquisadora é uma aca-fã (JENKINS, 2011), ou seja, uma acadêmica que estuda um produto do qual ela é fã, neste caso, a telenovela.

A partir do que foi exposto, o nosso problema pesquisa está expresso nas seguintes perguntas-chave: Como acontece a recepção da telenovela em época de transmídia e convergência? Quais as mediações que melhor incidem nessa recepção? Como elas se 
mostram estratégicas no processo receptivo? Quais as modificações mais significativas que ocorreram na assistência de telenovela desde o estudo de 2002?

Daí decorre o seguinte conjunto de hipóteses:

\section{Hipóteses teóricas:}

1) O inequívoco caráter transdisciplinar do campo da Comunicação e o caráter histórico da globalização e da tecnicidade exigem reconfigurações prementes da pesquisa de comunicação, em geral, e da pesquisa de recepção, em particular.

2) A transdisciplinaridade da Comunicação demanda estudos de cunho complexo e o uso de estratégia multimetodológica na pesquisa de recepção.

3) A classe social continua a mediação estruturante na recepção da telenovela no ambiente transmídia.

\section{Hipóteses empíricas:}

1) A proposta das mediações de Jesús Martín-Barbero atualiza-se no mapa das mediações como recurso teórico e metodológico essencial para a pesquisa empírica de recepção da telenovela.

2) A recepção tradicional de telenovela sofreu reconfigurações em função do ambiente transmídia e de convergência.

3) A assistência familiar da telenovela está em declínio e outras ritualidades assomam.

4) A sociabilidade virtual nas mídias sociais é a atual responsável pela continuidade das conversações sobre a telenovela, do repertório compartilhado e da nação imaginada.

\section{Objetivos gerais}

Os objetivos teóricos desta pesquisa são contribuir para o avanço teórico e metodológico de estudos de recepção de ficção televisiva relacionada à transmídia e convergência. Também pretendem colaborar para o resgate do caráter político das pesquisas de comunicação, principalmente aquelas que discutem as questões de empoderamento do receptor frente à perspectiva contemporânea da comunicação dentro do ecossistema transmidiático e convergente.

Outro objetivo, este de caráter mais epistemológico, é explorar e readequar teórica e metodologicamente a recepção de uma telenovela no atual ambiente transmídia 
e de convergência, a partir da releitura do estudo clássico de recepção Vivendo com a telenovela - mediações, recepção, teleficcionalidade (LOPES, BORELLI e RESENDE, 2002), realizado há 18 anos quando não existia tal realidade.

Como objetivos práticos, analisamos como a recepção da telenovela, basicamente de assistência coletiva familiar, foi reconfigurada pela transmidiação e convergência. Mais especificamente, propomo-nos a desvendar de que maneira isso acontece em duas famílias de diferentes classes sociais.

\section{Objetivos específicos}

1) Explorar teórica e metodologicamente a recepção da telenovela em tempos de transmídia e convergência.

2) Transpor, atualizar e readequar o protocolo metodológico de pesquisa utilizado no livro Vivendo com a Telenovela - mediações, recepção, teleficcionalidade, observando a recepção da telenovela $O$ Sétimo Guardião, em duas famílias, uma de classe popular (classe média baixa) e outra de classe alta (classe média alta).

3) Analisar como se dá a assistência da telenovela pelas duas familias, se a assistência em familia ainda é o principal local de recepção e se dispositivos transmídia estão presentes nesta recepção.

4) Verificar se a recepção das diferentes gerações acontece de maneira diferenciada devido às novas tecnologias.

5) Examinar se a classe social continua estruturante nos usos e apropriações que os receptores fazem da telenovela, mesmo com o ambiente transmídia e de convergência.

Para alcançar o que nos propomos, a tese tem a seguinte estrutura: a primeira parte é sobre a construção teórico-metodológica da pesquisa e contém os capítulos um, dois, três, quatro e cinco. No primeiro capítulo, situamos o nosso objeto de pesquisa, a telenovela brasileira, explicitando suas especificidades como produto cultural mais importante do país. Apontamos ainda questões relacionadas ao seu contexto histórico a fim de caracterizar e demarcar o movimento dialético entre a produção e a recepção do formato com a realidade do país. O capítulo dois é sobre o paradigma norteador da tese, 
o pensamento de Jesús Martín-Barbero acerca da Comunicação, denominada recentemente por Lopes (2018) de Teoria Barberiana da Comunicação. Demarcamos e refletimos sobre esta teoria acerca de como o autor estuda a comunicação e quais suas principais filiações teóricas. Além do que apresentamos e discutimos os Mapas das Mediações elaborado pelo autor e seus variados desdobramentos, pois eles são utilizados em nossa pesquisa como perspectiva teórico -metodológica e epistemológica. No capítulo três, trazemos uma análise sobre os avanços tecnológicos da atualidade e a demanda que causam nos meios de comunicação. Pontuamos, assim, questões relevantes sobre a evolução e as implicações do novo ecossistema comunicacional na contemporaneidade, com discussões sobre a cultura da convergência e as questões transmídia já consolidadas nessa nova forma organizacional dos meios e da sociedade. Por último, fazemos um estado da arte concernente à recepção transmidiática e à telenovela. O capítulo quatro da tese é sobre o nosso entendimento acerca de classe social, visto que é responsável pela visão de mundo pela qual os sujeitos fazem parte. Problematizamos a concepção de que a posição de classe influencia no modo como os receptores veem, leem e interpretam a telenovela. Discorremos, assim, sobre a importância e emergência do conceito nos estudos de comunicação do Brasil, país tão desigual. Discutimos ainda o aparecimento do termo "nova classe média" e nos posicionamos em relação a isso. No capítulo cinco, explicitamos e justificamos todo o percurso e as estratégias metodológicas utilizadas para construção e execução da pesquisa de campo com as duas famílias informantes. Além de relatarmos este percurso iniciando pelo livro inspiração da tese, pontuamos questões relacionadas às premissas multimetodológicas que guiam e norteiam a investigação. Apresentamos também, o protocolo multimetodológico da pesquisa empírica e explanamos como ele foi construído.

A segunda parte da tese diz respeito à pesquisa empírica e está organizada em dois capítulos: sendo assim, o capítulo seis apresenta o nosso universo de pesquisa, contendo a realidade das famílias informantes, a história da telenovela $O$ Sétimo Guardião e alguns aspectos sobre ela e ainda a telenovela reeditada conforme as escolhas das familias acerca das cenas mais marcantes da trama e suas impressões sobre tais cenas. O último capítulo, o número sete, trata sobre a análise das mediações na recepção da telenovela, em que pontuamos e articulamos tais mediações com o que foi apreendido durante a pesquisa de campo. Por fim, estão as considerações finais, em que 
fazemos um apanhado de tudo o que foi investigado a fim de cumprir nossos objetivos, comprovar ou refutar nossas hipóteses e responder a nosso problema de pesquisa. Porém, elas proporcionam verdadeiros insights para um ponto de partida, mais do que serem um ponto de chegada. 


\section{PARTE I:}

\section{A CONSTRUÇÃO TEÓRICO- METODOLÓGICA DA PESQUISA}




\section{Capítulo 1: O objeto de pesquisa: a telenovela brasileira}

À procura de situar o objeto de pesquisa da tese no contexto no qual é inserido, bem como explicitar e refletir sobre as suas características específicas, neste primeiro capítulo discorremos sobre a telenovela brasileira. O objetivo não é fazer um relato histórico e, sim, apontar momentos importantes dentro do contexto histórico em que aconteceram com suas principais especificidades, visto que existe um movimento dialético e de retroalimentação entre a produção, a circulação e a recepção da telenovela brasileira e a realidade do Brasil. Ainda buscamos conceituar este formato complexo e tão importante produto cultural do nosso país.

\subsection{A televisão: conceito e contínua relevância}

A televisão ocupa um lugar importante "nas dinâmicas da cultura cotidiana das maiorias, na transformação das sensibilidades, nos modos de construir imaginários e identidades" (MARTÍN-BARBERO e REY, 2004, p. 26) e possibilita uma experiência compartilhada por milhões de espectadores, fazendo com que eles criem um repertório cultural comum. É uma tecnologia e uma forma cultural (WILLIAMS, 2016) porque é um aparato doméstico que se tornou disponível como um meio ou elemento "em um processo de mudança que já está ocorrendo ou está prestes a ocorrer” (p. 26), sofreu modificações ao longo do tempo e continua se atualizando (passou do analógico para o digital, por exemplo) conforme as demandas sociais que ocorreram com o passar dos anos. Assim, a visão de Williams sobre a televisão rechaça o determinismo tecnológico, pois há a necessidade de se considerar como a tecnologia é articulada com grupos específicos de interesse e dentro de uma determinada ordem social. Qualquer tecnologia específica é um subproduto de um processo social e só adquire status efetivo quando é utilizada para fins que já estão contidos nesse determinado processo social (WILLIAMS, 2016, p. 27). O autor aborda a televisão como uma experiência cultural, ou seja, "engendrada pela articulação complexa entre práticas produtivas, determinantes tecnológicos e econômicos e a função social da televisão dentro do lar- assim como as estruturas formais dos gêneros televisivos individuais" (TURNER, 2016, p. 8).

Diferente de todos os outros sistemas de comunicação anteriores à radiofusão em que todos os elementos essenciais estavam separados, na televisão, esses estão dispostos em sequência ou em um conjunto de sequências alternativas disponíveis em uma única 
operação ou dimensão (quando o telespectador liga o aparelho de TV). É essa noção de fluxo que contribui para esta importante definição de Williams (2016) sobre a televisão como forma cultural e tecnologia:

Em todos os sistemas de radiofusão desenvolvidos, a organização característica - e, portanto, a experiência característica- é a de sequência ou fluxo. Esse fenômeno de um fluxo planejado talvez seja, então, a característica que define a radiofusão simultaneamente como uma tecnologia e uma forma cultural (WILLIAMS, 2016, p. 97).

A televisão "alterou o nosso mundo" (WILLIAMS, 2016, p. 26) consolidando-se como uma "forma social popular" (Ibdem, p. 129), sendo importante para o lar de milhões de pessoas ao propiciar acesso comum a telespectadores das mais variadas classes sociais. Por mais que não seja o objetivo deste capítulo recuperar a história da televisão, é importante ressaltar algumas especificidades e pontos relevantes com relação à sua evolução no Brasil. O país foi o segundo da América Latina a ter uma emissora de televisão e o sexto do mundo com a primeira transmissão em 1950, com a extinta TV Tupi Difusora de São Paulo. Ela teve forte influência do rádio, pois adaptava os programas radiofônicos para a tela, tinha o mesmo formato de programação e utilizava os mesmos técnicos e artistas (MATTOS, 2010; SODRÉ, 2001). Porém o fator econômico era limitante para o acesso e expansão da TV nos primeiros anos, pois era um equipamento caro em que apenas as elites tinham recursos para comprar:

Ter TV dava status, e não faltou quem convidasse as amigas para um chá com os artistas: elas na sala e eles na tela. A telinha se transformava, como bem diz Barbosa, 'no mais fascinante brinquedo do século XX'(PRIORE, 2019, p. 256).

Foi durante o regime militar (1964-1985) em que houve um investimento maciço do Estado no Brasil, na televisão, não só por ser o principal anunciante, mas também porque investiu em infraestrutura, estimulando o modelo comercial de televisão e possibilitando a formação de redes nacionais. Influenciou não só para o crescimento e consolidação deste meio, mas o utilizou como um elemento estratégico na política desenvolvimentista, de integração e como uma forma de garantir a segurança nacional do regime. Intervinha na programação por meio de regulamentações, severa censura e políticas normativas. Assim, em 1969, através do Ministério das Comunicações e da 
Embratel, foi inaugurada a Rede Básica de Microondas que viabilizava a transmissão ao vivo, interligando várias, mas não todas as regiões do país.

Até o final dos anos 70, a TV não suplantava os jornais e revistas em receita publicitária, não tinha um público de massa. A partir do Plano Nacional de Desenvolvimento I e II, o governo fez uma recomendação expressa de estímulo ao consumo. Isso significava formar novos consumidores, substituir o armazém pelo supermercado. Boa parte dos espectadores era de periferias urbanas e migrantes nordestinos. Para agradar este público, a TV adotou uma programação que misturava a incitação ao consumo de massa com conteúdos culturais nordestinos. O grotesco é uma designação estética para esse programa hîbrido que articula cidade e interior. É a papagaiada do circo no circuito eletrônico da TV ( SODRÉ apud PRIORE, 2019, p. 256).

Foi justamente ao longo dos anos 1970 que, com todos estes avanços e investimentos, a Rede Globo se tornou a TV aberta hegemônica com uma cobertura nacional e "constituiu-se como a síntese da cultura nacional, pois monopolizava a audiência, especialmente após a implementação do Padrão Globo de Qualidade" (PRIORE, 2019. p. 263). Mas foi apenas na década de 1980 que houve redução do preço dos aparelhos de TV e, aliado a isso, a ampliação do crediário no país que o equipamento passou a ser acessível a grande parte da população, crescendo, assim, o número de televisores no Brasil. Para Priore (2019, p. 257, 271), consumir se tornou uma nova forma de lazer e "cada vez mais pessoas preferiam se instalar no conforto de uma poltrona em casa a estar diante de uma tela exclusiva”.

Em 1985, com a tecnologia dos satélites Brasilsat foi possível avançar nas reproduções ao vivo e assim todas as regiões brasileiras puderam ser alcançadas pela televisão. Estavam então implantadas as redes nacionais e os sistemas de filiação das redes regionais a essas grandes emissoras, entretanto a concentração delas estava na Região Sudeste do país, pois detinha capital econômico e maior poder político, formando os conglomerados midiáticos nos quais a Rede Globo é, até hoje, o maior expoente. Sodré (1984, p.99) afirma que "a modernização tecnológica da comunicação, conjugada com a reconcentração da renda e a uma maior diversificação dos bens de luxo, favoreceu diretamente a expansão da TV”.

A televisão então passou a fazer parte do cotidiano dos brasileiros, tornando-se uma verdadeira companheira e ocupando um lugar de destaque nos lares, o que ocasionou mudanças na sociedade e nas sociabilidades: 
Enquanto o cinema catalisava a experiência da multidão, pois era em multidão que os cidadãos exerciam seus direitos sobre a cidade, o que agora a televisão catalisa é, ao contrário, a experiência doméstica, pois é na casa que as pessoas exercem agora cotidianamente sua participação na cidade (MARTÍNBARBERO, 2004, p. 298).

Conforme Lynn Spigel (1992, p. 7), a TV tem a habilidade de trazer "um outro mundo para dentro de casa" e por isso simboliza o progresso e as "afirmações utópicas sobre a capacidade humana de conquistar e domesticar o espaço".

Atualmente, apesar da grande oferta das novas tecnologias, a televisão ainda é o veículo de comunicação mais utilizado pelos brasileiros, ocupando posição dominante em relação aos outros meios. De acordo com o Mídia Dados $2018^{1}$ e com a Kantar Ibope Media $^{2}$, no país, o share ${ }^{3}$ total da TV é de $65 \%$, sendo que a TV aberta ultrapassa os 58\%. Há uma concentração de audiência em três grandes redes, sendo estas, respectivamente, Globo, Record TV e SBT. A penetração ${ }^{4}$ da TV aberta no Brasil é a maior entre todas as mídias, com números de $86,16 \%$.

\subsection{A telenovela brasileira: apontamentos e especificidades da narrativa da nação}

Ainda segundo a Kantar Ibope Media, a telenovela, nosso objeto de pesquisa, continua sendo um dos formatos televisivos mais assistidos diariamente pelos brasileiros 5 .

Por ter grande audiência e ser preferência nacional, a telenovela tem grande repercussão no cenário do país, sendo assim a "narrativa da nação" (LOPES, 2003), e ainda possui uma intensa penetração na sociedade porque tem uma "capacidade peculiar de alimentar um repertório comum por meio do qual pessoas de classes sociais,

\footnotetext{
${ }^{1}$ Disponível em: https://www.gm.org.br/midia-dados-2019. Acesso dezembro de 2019.

${ }^{2}$ Dis ponível em: https://www.kantaribopemedia.com/

3 Conforme o Kantar Ibope Media significa: a parcela de participação de determinado site, marca ou produto diante do total medido. Disponível em: https://www.kantaribopemedia.com/glossario/. Acesso em dezembro de 2019.

${ }^{4}$ Conforme o Kantar Ibope Media significa: a incidência de consumo de determinado produto, serviço ou mídia nos diferentes targets, isto é, nos diferentes agrupamentos da sociedade. Essa avaliação permite verificar em qual target o produto, serviço ou mídia em questão é mais consumido em relação à média geral da população e em relação a outros targets. Disponível em: https://www.kantaribopemedia.com/glossario/. Acesso em dezembro de 2019.

5 Disponível em: https://www.kantaribopemedia.com/dados-de-audiencia-nas-15-pracas-regulares-combase-no-ranking-consolidado-2503-a-03032019-3-2-2-3-2-2-2-2-2-2-2-2-2-2-2-2-2-2-2-2-2-2-2-2-2-2-2-

2-2-2-2-2-2-2/
} 
gerações, sexo, raça e regiões diferentes se posicionam e se reconhecem umas às outras" (LOPES, 2003, p. 18). Tal repertório comum compartilhado "está na base das representações de uma comunidade nacional imaginada que a TV capta, expressa e constantemente atualiza" (Ibdem) por oferecer a propagação de informações acessíveis e compreendidas em todas as camadas sociais e regiões do país, criando, assim, uma noção de pertencimento dessa nação imaginada. A telenovela aciona e mobiliza mecanismos de compartilhamento, participação e conversação entre os telespectadores e faz parte do cotidiano destes, pois ela "é tão vista quanto falada e seus significados são o produto tanto da narrativa audiovisual, produzida pela televisão, quanto da interminável narrativa oral produzida pelas pessoas" (LOPES, 2003, p. 30). Esta força e repercussão das telenovelas no Brasil hoje extrapola as conversas face a face e chega na internet através das redes sociais e blogs especializados no assunto.

Ao assistir as ficções, os telespectadores são levados a mundos e lugares conhecidos e desconhecidos contidos nas mais diferentes narrativas, por isso o consumo desse produto cultural também "inspira a formação de identidades" (LOPES, 2003, p. 18). Além disso, ao assistir a telenovela os receptores criam vínculos com o enredo e com as personagens das tramas, afinal "a longa extensão da narrativa possibilita que a telenovela seja confundida com a vida, o que estreita o vínculo do público com as personagens" ( LOPES e LEMOS et al., 2019, p. 20). Assim, a telenovela brasileira é definida

como um construto que ativa na audiência uma competência cultural e técnica em função da construção de um repertório comum, que passa a ser um repertório compartilhado de representações identitárias, seja sobre a realidade social, seja sobre o próprio indivíduo (LOPES, BORELLI e RESENDE, 2002, p. 23).

A ficção no Brasil possui características específicas que a diferencia das produções de outros países, não só pela sua qualidade, mas por retratar o país e, como já citado, por agendar e pautar inúmeras conversações. É o nosso produto cultural mais importante e "combina a forma do documentário e do melodrama televiso por promover em sua narrativa amplo espaço para problematizar questões da intimidade privada à vida social vigentes no país" (DEPEXE, 2015, p. 78). A telenovela tem a capacidade de fazer o deslocamento de assuntos pertencentes à esfera privada para o domínio público e "ao domesticar conteúdos afetos ao domínio público, operam também o movimento inverso, saturam o espaço público com temas e tratamentos 
convencionalmente restritos à intimidade" (HAMBURGUER, 2005, p. 169-170). Para Lopes (2003, p. 17), a telenovela é "um dos fenômenos mais representativos da modernidade brasileira, por combinar o arcaico e o moderno, por fundir dispositivos narrativos anacrônicos e imaginários modernos e por ter a sua história fortemente marcada pela dialética nacionalização-massmediação".

É sabido que há a filiação da telenovela ao romance - folhetim:

Colado no cotidiano, o folhetim se estrutura a partir de uma continuidade - não de uma coincidência - temporal entre o universo diegético e o extradiegético, abarcando telespectadores e autores. Os capítulos sucessivos fazem parte da rotina do público, que já sabe mais ou menos o que esperar daquele encontro diário com a vida de personagens que existem para compartilhar seus dramas cotidianos. O telespectador acompanha o desenrolar lento e repetitivo e os saltos repentinos sem necessariamente assistir a todos os capítulos" (HAMBURGUER, 2005, p. 44).

Para Ortiz, Borelli e Ramos (1989, p. 11), o romance folhetinesco é uma "espécie de "arquétipo da telenovela", porém os autores apontam que, para além da continuidade que existe entre o gênero folhetinesco e a telenovela há também rupturas, já que precisou percorrer um "movimento não-linear que, para se aclimatar em solo brasileiro, teve que passar por outros continentes, desde a soap-opera americana até a radionovela latino-americana" (Ibdem) e, ainda para os autores, é o contraste entre essas duas formas (a soap opera americana e a radionovela latino-americana) que permite enxergarmos com mais clareza o desenvolvimento da telenovela no continente latino-americano e, mais precisamente, no Brasil. As radionovelas proporcionaram o acúmulo de "um know-how sobre a literatura melodramática, que será posteriormente transferido para televisão" (ORTIZ, BORELLI e RAMOS, 1989, p. 28). Martín-Barbero (1992, p. 5, tradução nossa) afirma que a telenovela é "essa modalidade de melodrama em que as mais velhas narrativas se mesclam e fazem mestiçagem com as transformações tecnoperceptivas das massas urbanas, cuja 'oralidade secundária'(W. Ong) incorporou as gramáticas do audiovisual"6.

Para além de ser um produto midiático, o formato faz parte de uma indústria que é pautada pela lógica do mercado, pois movimenta uma grande variedade de profissionais

\footnotetext{
${ }^{6}$ esa modalidad de melodrama en la que las más viejas narrativas se mezclan y hacen mestizaje con las transformaciones tecnoperceptivas de las masas urbanas, cuya "oralidad secundaria" (W. Ong) ha incorporado las gramáticas de lo audiovisual.
} 
e gera lucros para as emissoras desde a década de 1950. Ele teve suas fases periodizadas em: sentimental (1950 a 1967), realista (1968 a 1990) e naturalista (desde 1990) ${ }^{7}$.

A primeira telenovela veiculada na televisão brasileira foi Sua vida me pertence, de Walter Foster, transmitida pela TV Tupi, em 1951, numa época em que, conforme Ortiz, Borelli e Ramos (1989), por a TV ser algo recente no país ainda não havia um total conhecimento de como explorar este novo meio. Por isso, os críticos da época consideravam que telenovela nada mais era do que uma radionovela com imagens marcada pela improvisação:

O pessoal do rádio, 'acostumado a utilizar só a voz em seu trabalho, não tinha uma expressão corporal adequada quando se encontrava diante das câmeras. O resultado é que a locução saía perfeitamente, mas a postura do corpo ficava em total desacordo com as necessidades da cena que estava sendo interpretada. Além disso havia a dificuldade de decorar o scripts. Habituados a ler diante do microfone, os atores tinham sérios problemas em memorizar o texto'(PORTO e SILVA apud ORTIZ, BORELLI e RAMOS 1989, p. 28, grifos do autor).

As ficções tinham forte influência do gênero melodramático bem como do cinema americano, visto que eram feitas inúmeras adaptações de filmes nesse início da telenovela no Brasil (ORTIZ, BORELLI e RAMOS, 1989). Além do que as obras eram marcadas por dicotomias sociais e individuais como:

[...] justiça/injustiça, fidelidade/infidelidade, amor/ódio. É como se universo se estruturasse por antinomias, que nos lembram o sistema de 'pensamento selvagem' dos povos primitivos. O herói é sempre o redentor ou mártir, por isso convive com o sofrimento e os obstáculos que a vida the coloca no caminho (ORTIZ, BORELLI e RAMOS, 1989, p. 30).

No início da década de 1960, a telenovela é "marcada pelo desprestígio, mas também com uma certa presença, pois consegue atravessar mais de uma década no vídeo" (ORTIZ, BORELLI e RAMOS, 1989, p. 54). E é justamente nessa época, como mencionado no início deste texto, que a televisão começa a se popularizar e a telenovela

\footnotetext{
7 Tais periodizações da telenovela brasileira são encontradas em diversos estudos como: Ortiz, Borelli e Ramos (1989), Mattelart e Mattelart (1989), Campedelli (1987) e Fernandes (1994).
} 
a ganhar a preferência dos brasileiros em detrimento de outros programas culturais como o teleteatro, por exemplo.

Em 1960, é fundada a TV Excelsior com o objetivo de "desenvolver um projeto brasileiro para televisão" (ORTIZ, BORELLI e RAMOS, 1989, p. 50) com a valorização de autores que escreviam textos nacionais em vez de adaptações. Foi na emissora que, viabilizada pela introdução do videoteipe, foi ao ar, em 1963, a primeira telenovela diária brasileira, a 2-5499 Ocupado, de Dulce Santucci. A obra foi também a primeira a receber patrocínio de uma grande marca de higiene pessoal, prática que se tornou comum a partir de então, visto que inúmeras marcas, principalmente as de higiene pessoal e de produtos de limpeza, viram no formato um filão para investir e atrair os consumidores que assistiam às telenovelas. A 2-5499 Ocupado marcou a história da ficção no país também porque, devido ao patrocínio que recebeu de ColgatePalmolive, foi possível a "contratação de vários profissionais: cenógrafos, maquiadores, cameramen, diretores de TV'(ORTIZ, BORELLI e RAMOS, 1989, p. 60). Criava-se então, no público, o hábito de assistir telenovela diariamente a partir dos horários fixados, administrados e organizados nas grades de programações das grandes redes de televisão do país.

Nessa década, as produções priorizavam as adaptações de romances e continham forte presença do melodrama clássico com temáticas dramáticas e dicotômicas do folhetim. No ano de 1964, o formato ganhou o horário nobre da televisão após o sucesso de $O$ Direito de Nascer, de Thalma de Oliveira e Teixeira Filho, veiculada pelas TVs Tupi e Rio. O formato telenovela então se transformou em uma nova "mania nacional" em que "famílias inteiras se postam diante do televisor e acompanham, do neto ao avô, aqueles episódios de folhetim eletrônico" (ORTIZ, BORELLI e RAMOS, 1989, p. 6162):

Diante do sucesso de Direito de Nascer os artigos de jornais apontam para mesma euforia: 'as crianças passaram a nascer com o nome de Albertinho Limonta; nas cidades o grau de utilização da rede sanitária caiu sensivelmente na hora da novela; e os encontros nacionais, desde sessões do Senado até ofícios religiosos, foram habilmente deslocados para não perturbar o drama da paternidade desconhecida' Exagero? Certamente, mas essas descrições impressionistas captam uma mudança de hábito que se enraíza nas diversas camadas da sociedade brasileira (ibidem). 
Em 1967, a TV Tupi tirou do ar o TV de Vanguarda, "encerrando definitivamente o ciclo do teleteatro, e iniciando a era da hegemonia da telenovela" (ORTIZ, BORELLI e RAMOS, 1989, p. 63). Com isso, as produções eram indispensáveis e obrigatórias nas grades das emissoras, sendo fundamentais na distribuição dos custos e horários, uma vez que a novela se tornou responsável pelo aumento dos índices de audiência.

$\mathrm{Na}$ mesma época, começaram a demarcar-se ainda mais as diferenças entre a dramaturgia latino-americana e a brasileira, sendo a principal delas o fato de que as tramas produzidas aqui, de certa forma, correspondiam a o que acontece na vida real. Eram histórias que se passavam no Brasil com temas urbanos e que faziam parte do cotidiano dos brasileiros, sempre com situações plausíveis de acontecer com qualquer telespectador, causando, assim, uma melhor identificação destes com os personagens das telenovelas (ORTIZ, BORELLI e RAMOS, 1989). Isto representou um rompimento com as características até então apresentadas pelas telenovelas no país e teve como principal expoente Beto Rockfeller, de Bráulio Pedroso, exibida pela TV Tupi, em 1968. A trama é considerada com um dos marcos da história da telenovela brasileira porque a narrativa abandonava os padrões até então estabelecidos nas produções anteriores, como as atitudes extremamente dramáticas e artificiais na interpretação dos atores:

Uma novela que rompe com os diálogos formais, propondo uma narrativa de cunho coloquial, repleta de gírias e de expressões populares. Reproduzindo fatos e fofocas retiradas de notícias de revistas e jornais da época, o enredo procurava reproduzir o ritmo dos acontecimentos no interior da própria narrativa. A preocupação de Bráulio Pedroso era trazer o cotidiano vivido para o vídeo, o que significava 'escrever uma novela com uma proposta realista', trabalhando inclusive a representação dos atores o mais próximo possível da realidade. Beto Rockfeller se distancia também do melodrama, na medida em que a figura principal é um anti-herói” (ORTIZ, BORELLI e RAMOS, 1989, p. 78).

Surgiu, então, pela primeira vez em uma telenovela brasileira, a figura do antiherói como protagonista com o intuito de aproximar o personagem das pessoas comuns, capazes de serem "boas" ou "más" conforme as situações enfrentadas no dia a dia. Segundo o próprio autor, “"era a primeira vez que numa novela aparecia um herói que não era impoluto, corajoso, maravilhoso. Ao contrário, o Beto era um mentiroso, um arrivista, um carreirista"” (Braúlio Pedroso apud ORTIZ, BORELLI e RAMOS, 1989, p. 79). Tais características para buscar aproximação com o público e contar a história de 
pessoas mais próximas da realidade na telenovela faziam com que ela estivesse conectada com o ambiente cultural do momento. Isto porque, depois de 1964, com o Cinema Novo também houve a busca por uma maior aproximação com o público com o filme Macunaíma, de Joaquim Pedro de Andrade, em 1969, que "recorre ao 'herói sem nenhum caráter' de Mário de Andrade para conseguir identificação num filme que abandona posturas intelectualizadas, colocando no lugar uma colorida diversão" (ORTIZ, BORELLI e RAMOS, 1989, p.79-80). Os movimentos Jovem Guarda e Tropicalista, no cenário musical, também mostravam a figura de "um trágico anti-herói" (Ibdem) inserido no cotidiano urbano de uma sociedade em transformação.

É ainda nesse final da década 1960, devido às perdas nas constantes lutas por audiência para a Globo, que as tevês Tupi e Excelsior ficaram para trás e estavam prestes a fechar. De acordo com Ortiz, Borelli e Ramos (1989), como não havia concorrência do mesmo porte, a Globo passou então a obter a hegemonia do espaço ficcional da televisão no país.

Na década de 1970, a novela dominava a programação nacional da Globo e competia com a produção importada de filmes, sendo um formato fundamental, superando, inclusive, a audiência dos shows de auditórios e noticiários (ORTIZ, BORELLI e RAMOS, 1989, p. 91) e se tornando o programa mais assistido de acordo com os índices do IBOPE (HAMBURGUER, 2000, p. 25).

Para Lopes (2009), foi a partir dos anos 1970 que a telenovela no país começou a ser também "recurso comunicativo", pois é uma narrativa que conjuga ações pedagógicas implícitas e deliberadas, age como componente de políticas de comunicação e cultura para o desenvolvimento da cidadania e dos direitos humanos na sociedade. Tem "capacidade de junção da matriz melodramática com o tratamento naturalista como fundamento da verossimilhança de suas narrativas e do efeito de credibilidade que alcançou" (LOPES, 2009, p. 32).

No mesmo período (1970), a novela Irmãos Coragem, de Janete Clair (Globo, 1970/1971) fez com que fosse afastada a noção de que telenovela é "coisa de mulher". Isto se deu devido a um maior interesse do público masculino pelo formato (ORTIZ, BORELLI e RAMOS, 1989). A explicação pode estar no fato de que foi inspirada em westerns norte-americanos, sendo inclusive chamada por uma revista especializada da época de "western brasileiro" ( HAMBURGUER, 2005, p. 65). 
Em 1973, a emissora carioca exibiu a primeira telenovela a cores da televisão brasileira: $O$ Bem-Amado, de Dias Gomes, trazendo, assim, mudanças consideradas "revolucionárias na televisão" do país (ORTIZ, BORELLI e RAMOS, 1989, p. 123):

Uma transformação tecnológica como a cor teve que ser absorvida aos poucos, exigindo um esforço do pessoal técnico e artístico, os quais tiveram que ser reciclados através de cursos para enfrentar os novos equipamentos. A novela colorida vai ainda ocasionar cuidados adicionais com a maquiagem $\mathrm{e}$ os figurinos, pois deslizes $\mathrm{e}$ imperfeições são notados com maior facilidade. Ela exige também maiores precauções com a iluminação, já que câmera a cores não capta grandes contrastes. Enfim, todo um know-how vai sendo absorvido na feitura da telenovela nos anos 70, e um novo padrão tecnológico vai se cristalizando.

Dois anos depois, em 1975, a Globo fixou os horários das telenovelas na grade de programação às $18 \mathrm{~h}, 19 \mathrm{~h}$ e $20 \mathrm{~h}$ e esta organização é mantida até os dias de hoje, com uma pequena variação em que a telenovela das $20 \mathrm{~h}$ agora é veiculada as $21 \mathrm{~h}$. Ortiz, Borelli e Ramos (1989, p. 93) ressaltam que, nesse momento, era o modelo realista que estava em voga e todo este processo de sedimentação das telenovelas da Globo aconteceu em paralelo "à cristalização de uma dramaturgia diversificada. Um primeiro ponto a destacar é o definitivo abrasileiramento do gênero; as histórias atravessam um período de nacionalização do texto, das temáticas e mesmo de procedimento de linguagem televisiva”. Houve então a exclusão dos textos melodramáticos importados bem como as adaptações acabaram sendo restringidas apenas aos romances nacionais e estrangeiros. No mesmo ano, para “[...] encontrar soluções que agradassem ao governo, a Globo iniciou uma série de novelas inspiradas em obras literárias, no horário menos nobre das $18 \mathrm{~h}$, de acordo com a preocupação nacionalista e educacional dos militares" (HAMBURGUER, 2005, p. 35).

Consolidava-se também, principalmente no horário das 19h, na Globo, as novelascomédia que desafiavam as narrativas tradicionais da produções, eram ousadas e continham críticas sociais nas entrelinhas do humor apresentado. Ortiz, Borelli e Ramos (1989, p. 99) afirmam que "essas estórias se caracterizam pela farsa, a paródia, o apelo constante ao riso. Elas cruzam a tematizam constantemente outros segmentos da indústria cultural, como as histórias -em -quadrinho, o cinema e a própria televisão". As telenovelas Super plá, (Tupi, 1969-1970), O cafona (Globo, 1971), A volta de Beto Rockfeller (Tupi, 1973), Feijão maravilha (Globo, 1979), de Braúlio Pedroso e Cuca 
legal (Globo, 1975), de Marcos Rey são exemplos destas tramas. Este gênero fez tanto sucesso, que reorientou e virou marca registrada da faixa horária até os dias de hoje. $\mathrm{Na}$ década de 80, a Globo produziu as novelas- comédia: Jogo da vida (1981), Guerra dos sexos (1983), Cambalacho (1986), Sassaricando (1988), de Silvio de Abreu; Transas e caretas (1984), de Lauro César Muniz; Amor com amor se paga (1984), A gata comeu (1985), de Ivani Ribeiro; Vereda Tropical (1984) e Bebê a bordo (1988), de Carlos Lombardi; Um sonho a mais (1985), de Daniel Más; Ti-ti-ti (1985) e Brega e chique (1987), de Cassiano Gabus Mendes.

Em 1976, houve um outro marco para a história da televisão no país com a exportação da primeira telenovela para a América Latina, "superando os problemas da língua e do domínio mexicano" (ORTIZ, BORELLI e RAMOS, 1989, p. 118). O Bem Amado foi dublada no México e vendida pela Globo primeiramente para a Telemontecarlo do Uruguai, e posteriormente, para outros países latino-americanos. O processo de exportação prosseguiu com a venda de Pecado capital (1975-1976), de Janete Clair, Dona Xepa (1977) e Escrava Isaura (1976-1977), de Gilberto Braga. Em seguida, houve a penetração das produções brasileiras no mercado europeu.

Ainda nesta década, a temática do coronelismo com intuito de fazer uma crítica ao momento político vivido no país foi explorada pelas tramas, mesmo ainda sob efeito de censura no país. Exemplos disso são as telenovelas da Globo Saramandaia (1976) e $O$ Bem Amado (1973), ambas de Dias Gomes, que tratavam do assunto, fazendo alusão ao realismo fantástico com seus personagens voadores e que explodiam. Segundo Hamburguer (2005, p. 91), Gabriela (1975), de Walter Durst, uma adaptação do romance de Jorge Amado e considerada por muitos a melhor novela da história, também "constituiu um bom exemplo do tratamento crítico, mas sempre ambivalente, que o coronel merece".

Mesmo assim, as temáticas femininas continuavam se impondo nas telenovelas porém, de uma maneira rearranjada para se ajustar ao mundo que estava se modernizando. E o grande sucesso Dancin' Days (Globo, 1978-1979) demonstrava isto com clareza como afirmou o próprio autor da trama na época:

é uma estória sobre a posição confusa da mulher nos dias de hoje', isto é, num momento em que transformações importantes ocorreram no papel da mulher dentro da sociedade, e que inclusive se encontravam aguçadas nas discussões dos movimentos feministas da época (Gilberto Braga para ORTIZ, BORELLI e RAMOS, 1989, p. 106). 
Foi a telenovela a primeira a influenciar a moda no Brasil com as roupas de cetim e as meias listradas e de lurex da personagem Júlia Matos interpretada por Sônia Braga. Dancin'Days também popularizou e projetou nacionalmente a disco music no Brasil (PRIORE, 2019, p. 262). Para Straubhaar (2007), a trama foi a primeira a consolidar no imaginário dos brasileiros a possibilidade de ascensão social quando "passa a (se) retroalimentar (d)o desejo das classes mais baixas de ascender à classe média retratada na televisão" (LOPES e LEMOS et al, 2019, p. 31).

Outras telenovelas da época apresentavam este "folhetim modernizado", ou seja, os “[...] temas folhetinescos são readaptados à realidade brasileira" (ORTIZ, BORELLI e RAMOS, 1989,p. 106), como é o caso de Selva de pedra, de Janete Clair ( Globo, 1972-1973), Plumas e paetês de Cassiano Gabus Mendes (Globo, 1980-1981) e Baila comigo de Manoel Carlos.

Simultaneamente a este processo de modernização, conforme Ortiz, Borelli e Ramos (1989, p. 106), permanecia uma grande variedade de telenovelas que ainda se aproximavam do folhetim melodramático "tradicional" para mobilizar o telespectador. Isto era um recurso utilizado por emissoras de TV que tinham dificuldade de produzir continuamente telenovelas, como Record, Tupi e Manchete. O SBT também investiu na década de 1980 e continua investindo até hoje, no melodrama tradicional para reaquecer a indústria televisiva e "praticamente a maioria das novelas são 'dramalhões' da escritora mexicana Marisa Garrido" (p. 107).

Assim, é possível afirmar que, a partir das décadas de 1970 e 1980, foi que "a novela se consolidou como repertório compartilhado entre os segmentos mais diversos do público" (HAMBURGUER, 2005, p. 38).

No final da década de 1980, as telenovelas Roque Santeiro (Globo, 1985-1986), de Dias Gomes, que teve sua primeira versão censura em 1975, e Roda de Fogo (Globo, 1986-1987), de Lauro César Muniz, eram tramas que "procuram se apresentar, para o público e para a sociedade, como narrativas legitimadas pelos temas políticos que abordam, assim como pela forma em que são realizadas" (ORTIZ, BORELLI e RAMOS, 1989, p. 96).

Em 1988, a nova Constituição aprovou a abolição de qualquer tipo de censura no Brasil, acabando, assim, com as censuras às telenovelas. Um marco dessa redemocratização do país na ficção foi a telenovela Vale Tudo (Globo, 1988-1989), de 
Gilberto Braga. Da mesma forma que em Roque Santeiro, foram usadas nas vinhetas de abertura as cores nacionais que tornavam "explícitas as referências ao imaginário nacional, bem como a eventos da época" (HAMBURGUER, 2004, p. 105). Ainda conforme Hamburguer (2005), tais obras compartilhavam a mesma estrutura narrativa, tinham personagens arquétipos e o mesmo apelo de representar o contemporâneo fazendo referência clara à corrupção que caracterizava a ordem social e política do país naquele momento. O Salvador da Pátria (Globo, 1989), de Lauro César Muniz também fazia referência a símbolos nacionais e ao contexto atual da época.

Assim, "a década de 1990 inaugurou um período, ainda em curso, de diversificação da estrutura e da programação televisiva, redemocratizado" (HAMBURGUER, 2005, p. 36). É ainda nessa década que se inicia a fase já citada acima, naturalista, que perdura até os dias de hoje.

Também em 1990, a Manchete apresentou uma telenovela que é exemplo de trama alternativa para a época por reinterpretar o Brasil, valorizando aspectos renegados no modelo "país do futuro" (HAMBURGUER, 2005, 117). Pantanal, de Benedito Ruy Barbosa, foi ao ar na tevê concorrente e teve boa repercussão com a audiência, embora não competisse diretamente com a Globo, já que era exibida em horário mais tarde, às 21h30:

\begin{abstract}
A novela alternativa teve êxito ao inovar através de uma linguagem diferenciada: com ritmo diferente, mais lento que o convencional, foi gravada em cenários exóticos da região do Pantanal mato-grossense e fez da exibição quase turística da paisagem local - incrementada por uma sensualidade ousada, que incluía a nudez feminina - um dos seus atrativos (HAMBURGUER, 2005, p. 37).
\end{abstract}

Na segunda metade dos anos 1990, com a diversificação da estrutura da televisão, como a implantação do cabo e a consequente migração das classes altas para esse novo sistema disponível, a introdução do videocassete e o crescimento da concorrência com as novelas do SBT e Manchete (Pantanal), a Globo, apesar de continuar líder, teve queda de audiência. Mesmo assim, a telenovela deslocou-se, colocando em pauta novas representações sociais que questionavam as anteriores (LOPES, 2009), e ainda:

[...] continuou a captar e expressar noções contraditórias sobre as relações entre domínios como masculino e feminino, público e privado, política e intimidade, notícia e ficção, mas a segmentação de 
audiências, de produtores e programação colocou em questão a possibilidade de uma representação nacional" (HAMBURGUER, 1989, p. 38)

As tramas que traziam como tema principal a discussão do Brasil como nação continuaram a ser apresentadas ao longo da década. Deus nos Acuda (Globo, 1992), de Silvio de Abreu, Maria Adelaide Amaral e Alcides Nogueira "explorou até o limite esse aspecto de interpretação da nacionalidade com base na crônica dos acontecimentos políticos" (HAMBURGUER, 2005, p. 130). A obra, veiculada no horário das 19h, característico por exibir comédia, acabou sendo uma sátira política do Brasil e teve repercussão nacional e internacional. Dois anos depois, o país continuava pautando as telenovelas, com mais uma ficção em que a palavra "pátria" fazia parte do título, estreava Pátria Minha (Globo, 1994), de Gilberto Braga.

Desta forma, todas estas telenovelas citadas marcaram fortemente essa capacidade que o formato tem de pautar, aglutinar e discutir dialeticamente o cotidiano conforme o contexto vivido no momento de sua veiculação. Hamburguer (2005) afirma que o horário nobre da TV tornou-se local privilegiado de problematizar a nacionalidade:

\begin{abstract}
A referência explícita às cores nacionais nas vinhetas de abertura, juntamente com a alusão a eventos ou a práticas políticas conhecidas, situam as oposições convencionais entre rural e urbano, homem e mulher, pais e filhos, ricos e poderosos, pobres e desprovidos de poder, em termos da nação ( HAMBURGUER, 2005, p. 105).
\end{abstract}

Após a renúncia de Fernando Collor à presidência da República, em 1992, tiveram destaque as chamadas "novelas de intervenção", prestadoras de serviço "[...] na medida em que se propõem a intervir diretamente em determinados assuntos pontuais, escolhidos pelos autores, de acordo com as finalidades de seus respectivos estilos" ( HAMBURGUER, 2005, p. 131). Os maiores exemplos desse tipo de narrativa são Renascer (Globo, 1993), O Rei do Gado (Globo, 1996-1997) e Terra Nostra (Globo, 1999-2000), todas de Benedito Ruy Barbosa, tramas que para Hamburguer (2005), tinham o estilo de Pantanal, mas de forma diluída. A autora ainda sustenta que a telenovela então passou a ser reconhecida como um espaço legítimo para mobilizar diversos modelos de interpretação e reinterpretação da nacionalidade, bem como os modelos de estrutura familiar e de relações de gênero no país. $O$ Rei do Gado foi 
marcada por dar uma visibilidade inédita ao MST (Movimento dos Trabalhadores Rurais Sem Terra), pois "incorporou a luta contemporânea pela reforma agrária" (HAMBURGUER, 2005, p. 135). Com exceção de Terra Nostra, que foi dirigida por Jayme Monjardim, as outras duas (Renascer e $O$ Rei do Gado) tiveram a direção de Luiz Fernando Carvalho, que trabalhou o distanciamento no tempo e/ ou no espaço e "busca forjar uma linguagem cinematográfica para as novelas, usando planos longos e experimentando com pouca ou nenhuma luz artificial" (HAMBURGUER, 2005, p. 127). Porém, apesar de serem consideradas as telenovelas mais populares da década, os índices de audiência diminuíram.

$\mathrm{Na}$ década de 2000, a telenovela brasileira continuou realizando mudanças em suas características narrativas, que foram se tornando cada vez mais complexas, principalmente no que diz respeito à hibridização de gêneros e às formas de serialidade. Para Mittell (2006), que analisa essa complexificação na televisão americana, ocorre a hibridização das duas formas de serialidade: a serial (forma contínua, dividida em capítulos em que o arco dramático perpassa toda a narrativa) e a série (forma episódica, dividida em episódios em que os arcos são fechados, não ultrapassando a unidade do episódio). Quanto à categorização de tais formatos, Lopes e Greco et al. (2016, p. 171) afirmam que "um grave problema com que nos deparamos no Brasil é a falta de distinção entre esses dois formatos, tanto do lado de quem produz como de quem consome". Apesar de existirem exemplos pontuais do decorrer da história da telenovela sobre esta hibridização de formas de serialidade que se unem ao folhetim, foi a partir de 2003 que a prática se tornou mais comum nas tramas brasileiras. Exemplos são as telenovelas Mulheres Apaixonadas (2003), de Manoel Carlos e Kubanacan (2003), de Carlos Lombardi, ambas da Globo, por apresentarem diversos plots ${ }^{8}$ na mesma trama dando agilidade e dinamismo ao enredo (LOPES e GRECO et al., 2016, p. 171).

Tais características de hibridização entre gêneros e formatos, presentes na maioria das telenovelas do país na atualidade, têm sido observadas ao longo dos anos pelo Obitel. O Observatório destaca A Favorita, escrita por João Emanuel Carneiro e exibida pela Globo, em 2008, por ter apresentado inúmeras inovações no formato e por ter uma "narrativa de ritmo intenso, o que ocasionou diversas viradas na história antes mesmo do final do folhetim" (LOPES e GRECO et al., 2016, p. 173). Em 2011, O Astro

\footnotetext{
${ }^{8}$ Para Campedelli (1987, 45-46) plot é: "um acontecimento em torno do qual gravitarão os personagens". A autora considera a telenovela multiplot devido à grande quantidade de acontecimentos demandada pela duração do formato.
} 
(Globo, 2011), de Alcides Nogueira e Geraldo Carneiro, remake baseado na trama de Janete Clair de 1977, foi a primeira telenovela exibida no horário das $23 \mathrm{~h}$ "destinado principalmente a remakes e adaptações de novelas famosas, em formato de mais curta duração (média de 70 capítulos)" (Ibdem, p. 172 ). A sua narrativa se deu de forma episódica em que cada capítulo da trama possuía um plot, em que seu desenvolvimento central afetava os protagonistas centrais e as personagens de outros núcleos, sendo tudo solucionado no fim do mesmo capítulo com gancho para o capítulo seguinte. A telenovela recebeu o Emmy Internacional de melhor telenovela em 2012.

Outra ficção de destaque que exemplifica esta maneira de se fazer novela no país foi Avenida Brasil, também de João Emanuel Carneiro, exibida em 2012 pela Globo. Considerada um fenômeno midiático (media event), "marcou a história da televisão brasileira no que se refere a índices de engajamento da audiência com a trama ficcional do horário nobre" (LOPES e MUNGIOLI et al., 2013, p. 151) ${ }^{9}$, além de registrar uma média de $41,51 \%$ da audiência nacional com um share de $66,5 \%{ }^{10}$. A novela trabalhou o clássico enredo da vingança com a convergência dos gêneros drama, suspense e comédia e sua "agilidade nas ações e nos diálogos uniu-se a uma técnica comum às telenovelas das décadas de 1970-1980, a dos ganchos dramáticos ao final de cada capítulo" (LOPES e GRECO et al., 2016, p. 173):

[...] o sucesso e o impacto de Avenida Brasil decorrem de um conjunto de fatores que, em nosso entender, elevou o grau de exigência do público e da crítica a um novo patamar. Esse patamar se caracteriza pela adoção de recursos narrativos e estéticos que colocam Avenida Brasil como uma espécie de divisor de águas em termos de telenovela. Como ocorreu com Beto Rockfeller (Tupi, 1968) - telenovela considerada responsável pela criação de um novo paradigma de telenovela pela adoção de um modo de narrar (Lopes, 2009) e de representar os brasileiros (em teledramaturgia) na TV -, Avenida Brasil abordou temas e problemas já vistos em outras telenovelas, mas o fez incorporando e traduzindo de maneira magistral o esprit $d u$ temps de um país no qual ocorrem grandes mudanças sociais que criam espaços simbólicos nos quais Brasil - A telenovela como fenômeno midiático reverberam os discursos de novos protagonistas. Entre as mudanças sociais está a ascensão de milhões de brasileiros à "nova classe C" (LOPES e MUNGIOLI et al., 2013, 156-157).

\footnotetext{
${ }^{9}$ Sobre essa repercussão de audiência e consumo em múltiplas plataformas promovido por Avenida Brasil, iremos tratar no Capítulo 3 dessa tese.

10 Ver: http://especial.globouniversidade.redeglobo.globo.com/livros/Obitel2013 portugues.pdf. Acesso setembro 2019.
} 
A reprise da telenovela iniciada em 2019, no Vale a Pena Ver de Novo, já conquistou a melhor audiência da faixa horária nos últimos dez anos ${ }^{11}$.

Amor à Vida (Globo, 2013-2014) de Walcyr Carrasco também teve repercussão positiva da audiência, conforme o Obitel, e exibiu o primeiro beijo entre dois homens em telenovelas da Globo. Em 2015, houve uma resposta conservadora da Record TV com o sucesso Os Dez Mandamentos, de Vivian de Oliveira, consagrando, assim, o nicho de novelas bíblicas desenvolvidas pela emissora ${ }^{12}$.

Ao longo da década, a telenovela no país continuou acompanhando e se inserindo no contexto de novas tecnologias, especialmente digitais, bem como dos fenômenos de globalização e cultura. Por isso, as experiências já citadas de confluência entre gêneros e formatos seguiram e seguem sendo realizadas. O equilibrio entre as formas serial e série aparece, mais uma vez, em uma trama de João Emanuel Carneiro com A Regra do Jogo (Globo, 2015), que 'trouxe uma tensão explícita entre capítulo e episódio: cada capítulo foi numerado e recebeu um título que aludia aos acontecimentos do dia, ligados ao núcleo central" (LOPES e GRECO et al., 2016, p. 173). O mesmo aconteceu com a telenovela das 23h Verdades Secretas (Globo, 2015), de Walcyr Carrasco:

[...] soube se aproveitar muito bem tanto do formato telenovela - na elaboração de ganchos fortes aos finais dos capítulos - como do formato série - relacionado ao encadeamento das ações dramáticas de cada núcleo. Também foi apontada a agilidade da trama em sua duração mais curta, além da qualidade estética obtida pela direção (LOPES e GRECO et al., 2016, p. 173).

Em 2016, Velho Chico marca a volta de Benedito Ruy Barbosa e do diretor Luiz Fernando Carvalho ao prime time da Globo, rompendo o cânone estético e retratando a volta do Brasil rural no horário das 21h. (LOPES e GRECO et al.,2017). Com uma narrativa mais contemplativa em relação às tramas de viés realista e centradas em favelas e comunidades de grandes centros urbanos apresentadas na faixa horária, o autor pretendeu resgatar o "amor e a emoção" do gênero melodrama para tratar os elementos fundadores do país, opondo tradição e modernidade (NÉIA, 2016).

\footnotetext{
11 Ver em: https://portalovertube.com/noticias-da-tv/avenida-brasil-e-a-novela-de-maior-audiencia-dovale-a-pena-ver-de-novo-em-10-anos/ Acesso em janeiro 2020.

12 Ver Anuário Obitel 2016 e 2017 disponível em: https://blogdoobitel.wordpress.com/anuario/ Acesso em agosto 2019.
} 
Um ano depois, este "Brasil profundo" (LOPES e GRECO et al., 2018, p.125) deslocado do eixo Rio São Paulo, e instaurado com Velho Chico, continua sendo apresentado no horário das $21 \mathrm{~h}$ com os títulos O Outro Lado do Paraíso (Globo, 20172018), de Walcyr Carrasco e Força do Querer (Globo, 2017), de Glória Perez. Esta última trouxe temáticas fortes como questões de identidade e políticas de gênero e o tráfico de drogas sem a dicotomia favela/ classe média urbana carioca, além de ter marcado "a volta do sucesso de audiência no horário nobre. O último capítulo obteve média de 50 pontos, a maior desde Avenida Brasil (Globo, 2012), cujo final marcou 56 pontos" (Ibidem, p. 126).

A hibridização de gêneros e formatos e a diversificação audiovisual continua sendo marcante nas telenovelas produzidas na atualidade, bem como "o desenvolvimento de expressões transmídias ${ }^{13}$, em 2018, tem se mostrado proveitoso para as ficções tanto na televisão aberta e paga quanto nas empresas de VoD (LOPES e LEMOS et al. 2019, p. 96). Uma das razões apresentadas para o sucesso destas narrativas dinâmicas e hibridizadas pode estar no sucesso das séries no panorama internacional, já que "a estrutura de múltiplos enredos permite identificações flexivas e variáveis de espectadores, pertencentes a segmentos variados da população, personagens, temas e lugares que cada série problematiza" (HAMBURGUER e GOZZI, 2019, p. 8).

Outra característica marcante nas telenovelas do país, percebida com mais força a partir dos anos 2000 e cada vez mais consolidada, é a introdução nas tramas de merchandising social e ações socioeducativas. Tal especificidade é definida pela “inserção de cenas que, de modo explícito e pedagógico, expõem problemas sociais do país é marca distintiva da telenovela brasileira" (LOPES e MUNGIOLI et al., 2013 p. 134).

A fusão dos domínios do público e do privado realizada pelas novelas lhes permite sintetizar problemáticas amplas em figuras e tramas pontuais e, ao mesmo tempo, sugerir que dramas pessoais e pontuais podem vir a ter significado amplo. Nesse sentido, são exemplares os casos da novela Barriga de Aluguel (1990) que conta a história de uma inseminação artificial; de transplante de coração em De Corpo e Alma (1992); a destruição do meio ambiente em Mulheres de Areia (1993); a chegada da internet em Explode Coração (1995); a violência urbana em A Próxima Vítima (1995) e Torre de Babel (1998); a

\footnotetext{
${ }^{13}$ Como já citado tal assunto será desenvolvido no Capítulo 3 dessa tese.
} 
violência contra a mulher e os idosos em Mulheres Apaixonadas (2003); a clonagem humana e as drogas em $O$ Clone (2001); a deficiência visual em América (2005); a síndrome de Down em Páginas da Vida (2006); a diversidade racial e sexual em Duas Caras (2008); a saúde mental e a diversidade cultural em Caminho das Índias (2009) (LOPES, 2009, p. 27-28, grifo nosso).

Diversos temas foram abordados como homossexualidade, abuso sexual, direitos dos trabalhadores domésticos, HIV/AIDS, Síndrome de Down, tráfico de pessoas, e, recentemente, um assunto que teve enorme repercussão no país - a questão dos transgêneros pautada pela telenovela já citada, Força do Querer (Globo, 2017) e também discutida em A Dona do Pedaço (Globo, 2019), de Walcyr Carrasco, bem como as discussões acerca do machismo, homofobia, preconceito religioso e racismo em Segundo Sol, de João Emanuel Carneiro (Globo, 2018) (LOPES e LEMOS et al., 2019, p. 97). A telenovela no ar atualmente, Amor de Mãe (Globo 2019), de Manuela Dias também traz o merchandising social, debatendo questões ambientais, abandono, tráfico e adoção de crianças.

Desta forma, por suas especificidades de produção e de repercussão na audiência, entendemos que a telenovela é, então, um locus estratégico para os estudos de comunicação no país, tanto nos aspectos de sua produção quanto de sua recepção. Ademais, ela continua sendo muito assistida pelos brasileiros até em tempos de novas mídias. 


\section{Capítulo 2: A Teoria Barberiana da Comunicação}

Neste segundo capítulo, trazemos o paradigma norteador deste trabalho, o consolidado e atual pensamento acerca da Comunicação de Jesús Martín-Barbero. Esta concepção completa e complexa que o autor tem do campo comunicacional foi denominada recentemente por Lopes (2018) de Teoria Barberiana da Comunicação. Relatamos e refletimos sobre essa Teoria, apontando, primeiramente, algumas questões que fizeram e fazem parte do entendimento do autor acerca do que é a comunicação, suas inspirações, especificidades e principais filiações teóricas. Em segundo lugar, apresentamos e discutimos um dos legados mais importantes de Martín-Barbero, os Mapas das Mediações, utilizados e problematizados nesta tese como perspectiva teórico -metodológica e epistemológica.

\subsection{Jesús Martín-Barbero: notas sobre o cartógrafo da complexidade}

O filósofo, antropólogo e semiólogo espanhol naturalizado colombiano tem papel fundamental tanto na constituição quanto na atualidade do campo da Comunicação no continente latino-americano, pois, "poucos autores possuem obra tão influente e significativa" (LOPES e KUNSCH et. al., 2018, p. 7) devido à sua contribuição de mais de quatro décadas com "produção intelectual cujos desdobramentos são potentes e até agora inesgotáveis na compreensão do que significa a comunicação na América Latina" (JACKS, SCHIMITZ e WOTTRICH, 2019, p. 25, tradução nossa) ${ }^{14}$. Couldry (2018, p. 35) acrescenta que, "[...] esse autor e sua obra devem ser devidamente inseridos na história global dos estudos de comunicação".

A riqueza da vasta contribuição do autor está justamente na amplitude do seu pensamento complexo e transdisciplinar. O próprio autor "[...] nega que seu pensamento pertença a um escopo disciplinar uno" (JACKS, ESCOSTEGUY e RONSINI, 2018. p. 11), especialmente porque pensa o campo da comunicação como hỉbrido, transdisciplinar, que se articula com outros campos teóricos. Esta visão contemporânea sempre esteve presente em suas reflexões sobre a comunicação, tendo como ponto de partida a cultura, compreendendo a cultura popular como forma de enfrentamento à

\footnotetext{
${ }^{14}$ No original: "producción intelectual cuyos desdoblamientos son potentes y hasta ahora inagotables en la comprensión de lo que significa la comunicación en América Latina".
} 
cultura hegemônica e ocasionando o entendimento das relações entre o massivo e o popular. Para ele, as combinações interdisciplinares são essenciais para que seja possível pensar os meios de comunicação e sua relação direta com a cultura, a economia e a política. Assim:

Transdisciplinaridade que em modo algum significa a dissolução dos problemas-objeto do campo da comunicação nos das outras disciplinas sociais, se não a construção das articulações e intertextualidades que possibilitam pensar os meios e as demais indústrias culturais como matrizes de desorganização e reorganização da experiência social e da nova trama de atores e estratégias de poder (MARTÍN-BARBERO, 1996, p. 62, tradução nossa) ${ }^{15}$.

Mas a inquietação sobre a transdisciplinaridade surgiu desde o lugar que chama de “incômodo" da filosofia (MARTÍN-BARBERO, 2018, p. 89), quando ministrava aulas de filosofia em uma escola colombiana. Segundo ele, os ensinamentos filosóficos eram feitos a partir de relatos de experiências de vida.

Em entrevista dada Lopes sobre esta interdisciplinaridade da comunicação, o autor chegou a afirmar que esta questão coloca os pesquisadores do campo diante de uma "epistemologia que coloca em crise o próprio objeto de estudo" (MARTÍN-BARBERO, 2009, p. 153). Desta maneira, o campo comunicacional possibilita investigações que se apropriam dos mais variados conceitos, como por exemplo, os oriundos de campos da antropologia, sociologia, psicologia, letras, etc. Isto porque, há uma diversidade de objetos/problemas de pesquisa, principalmente por ser um campo complexo e estar em constante desenvolvimento e atualização ocasionados pela globalização, pelas novas tecnologias e abarca o cotidiano da sociedade, em constante luta de poder e hegemonia. Assim, o pensamento inter, extra e transdisciplinar de Martín-Barbero corrobora com o Paradigma da Complexidade de Morin (2005), que propõe um olhar extradisciplinar e em direção a uma abertura contrária da hiperespecialização do pesquisador. Portanto,

\footnotetext{
${ }^{15}$ No original: "Trans-displinariedad que en modo alguno significa la disolución de los problemas-objeto del campo de la comunicación en los de otras disciplinas sociales, sino la construcción de las articulaciones e intertextualidades que hacen posible pensar los medios y las demás industrias culturales como matrices de desorganización y reorganización de la experiencia social y de la nueva trama de actores y estrategias de poder".
} 
para ter o pensamento não limitado acerca da comunicação na América Latina, MartínBarbero se inspirou em vários autores provenientes de diferentes campos teóricos:

[...] bebi das fontes, porque foi quando recebi, para pensar a comunicação, uma série de insumos de tipo filosófico, antropológico, inclusive a partir de uma certa concepção da crítica literária que coloca a comunicação como fenômeno muito forte em termos antropológicos e filosóficos, e muito antes que Habermas se dedicasse a fazer sua obra da comunicação (MARTÍN-BARBERO, 2018, p. 106).

Tal deslocamento disciplinar do autor foi algo natural que aconteceu ao longo do seu itinerário intelectual, afirmando que "vinha da filosofia e, pelos caminhos da linguagem, encontrei a aventura da comunicação. E da morada heideggeriana do ser cheguei assim, com meus ossos, na casa de favela dos homens, construída com barro e hastes de bambu, mas com radiotransmissores e antenas de televisão" (MARTÍNBARBERO, 1997, p. 15). Entre os muitos autores que influenciaram o espanholcolombiano estão diversos latino-americanos, e especialmente, brasileiros. Longe de reduzirmos a vasta bagagem teórica, epistemológica e metodológica do autor, apontaremos aqui alguns dos pensadores que, no nosso ponto de vista, foram significativos para construção da teoria comunicacional de Martín-Barbero.

O brasileiro Paulo Freire se sobressai e foi utilizado na tese em filosofia defendida por Martín-Barbero em 1972, na Universidade de Lovaina, na Bélgica. A pedagogia libertária e a complexa teoria da linguagem foram determinantes para Martín-Barbero pensar a filosofia da linguagem com o olhar na comunicação. A tese é "um manifesto que coloca a agenda de suas futuras reflexões, uma rota que, como lição inaugural, constrói os itinerários e as apostas que viriam posteriormente" (MARROQUÍN, 2018, p. 194, tradução nossa) ${ }^{16}$. Seu pensamento estava dividido em três partes, e, como ele mesmo afirma (MARTÍN-BARBERO, 2018, p. 97), Paulo Freire foi fundamental para a estruturação da tese: "os três passos estavam em Paulo Freire: a linguagem como objetivação da experiência humana, de opressão, de

\footnotetext{
${ }^{16}$ No original: "un manifiesto que coloca la agenda de sus futuras reflexiones, una ruta que, como una lección inaugural, construye las itinerancias y las apuestas que vendrán posteriormente."
} 
alienação, mas também de todas as possibilidades que havia de se reapropriar da linguagem e transformá-la em um espaço de emancipação e libertação”. A comunicação e a linguagem são capazes de libertar os sujeitos, sendo a linguagem: "a textura dialógica da comunicação" (Ibdem).

Inúmeros outros pensadores de diferentes origens e campos do saber foram influências para compor o pensamento complexo de Martín-Barbero. A partir do francês Paul Ricoueur, por exemplo, refletiu sobre a memória e a promessa, abordando como Ricouer "trata essa mediação e como estavam as chaves do reconhecimento no contexto simbólico que é sua crítica a Lévi- Strauss: já que o estruturalismo achata a linguagem sobre a significação e o símbolo" (MARTÍN-BARBERO, 2018, p. 98). Foi proveniente dessa primeira reflexão o que posteriormente o autor espanhol- colombiano pensaria sobre o "drama do reconhecimento" de Peter Brooks como chave para compreender o melodrama, rechaçando a noção de Althusser de que o reconhecimento se esgotava no ideológico.

Foram inúmeras as contribuições de Walter Benjamin, entre elas as concernentes à indústria cultural e ao popular na cultura. Martín-Barbero exalta o autor alemão em comparação à negatividade presente nas reflexões dos outros pertencentes da Escola Crítica relacionadas à indústria cultural, pois, "para Benjamin, pelo contrário, pensar a experiência é o modo de alcançar o que irrompe na história com as massas e a técnica. Não se pode entender o que se passa culturalmente com as massas sem considerar sua experiência" (MARTÍN-BARBERO, 2009b, p. 80, grifo do autor). Ademais, "Benjamin não investiga a partir de um lugar fixo, pois toma a realidade como algo descontínuo" (Ibdem). O autor serviu ainda de cerne para o estudo das relações de transformação das formas de produção e as mudanças que ocasionam no espaço da cultura, sendo o primeiro a falar da noção de mudanças de sensibilidade, do sensorium, trabalhado por Martín-Barbero como mediação. Desta mediação, falaremos com maior profundidade no próximo tópico deste capítulo. A provocação de pensar as mudanças que configuram a modernidade a partir do espaço da percepção e a visão qualitativa do tempo também partiram das leituras de Walter Benjamin. O alemão e o francês Michel de Certeau fizeram Martín-Barbero estudar o espaço ocupado na cidade moderna fragilizada do nacional devido às lógicas globalizadoras produzidas. "A centralidade da noção de prática nesta dimensão da espacialidade que aponta JMB, remete necessariamente a Michel de Certeau e estabelece uma íntima conexão com o habitar'(FELIPPI,VILLELA 
e SILVEIRA, 2019, p. 106, tradução nossa) ${ }^{17}$. Sobre a espacialidade, também discutiremos no próximo tópico deste trabalho.

Ressaltamos ainda as influências de Pierre Bourdieu e suas noções de habitus, ação social, ator social, distinção, reprodução e classe social para discutir massa e cultura popular. Isto porque, "pensar na reprodução é para Bourdieu a forma de tornar compatível no marxismo uma análise da cultura que ultrapasse sua sujeição à superestrutura, mas que o tempo todo desvele seu caráter de classe" (MARTÍNBARBERO, 2009b, p. 118). A perspectiva de classe social a partir de Bourdieu também é seguida nesta tese, portanto, o Capítulo 4 será destinado à classe social e às reflexões do autor francês. Articulado com os conceitos de Bourdieu, Martín-Barbero também recorreu ao italiano Antonio Gramsci para compor sua concepção de popular na cultura massiva. Ressalta a importância do "[...] papel jogado pelo pensamento de Gramsci no desbloqueamento, a partir do marxismo, da questão cultural e da dimensão de classe na cultura popular" (Ibdem, p. 112). De Gramsci tomou os conceitos de hegemonia, ou seja, a cumplicidade dos oprimidos nas condições de opressão, assim:

[...] possibilitando pensar o processo de dominação social já não como imposição a partir de um exterior e sem sujeitos, mas como um processo no qual uma classe hegemoniza, na medida em que representa interesses que também reconhecem de alguma maneira como seus as classes subalternas (Ibdem, p. 112)

Martín-Barbero, então, com base nessa multiplicidade de autores, concebe seu pensamento comunicacional [...] no marco do processo das culturas" (COGO, 2007, p. 3) e sua noção de cultura parte de Raymond Williams, “[...] que ao longo da história do conceito o reconstrói com o objetivo de operacionalizá-lo a partir da cultura comum, da cultura da classe trabalhadora e de suas práticas " (JACKS, SCHMITZ e WOTTRICH, 2019 , p. 51 $)^{18}$. Ao longo de toda a sua obra, Martín-Barbero sempre esteve comprometido com essa específica forma de estudar e olhar para a cultura com uma

\footnotetext{
${ }^{17}$ No original: “ La centralidad de la noción de práctica en esta dimensión de la espacialidad que señala JMB, remite necesariamente a Michel de Certeau y establece una íntima conexión con el habitar.

18 No original: "[...] que en el recorrido histórico del concepto lo reconstruye con vistas a operacionalizarlo desde la cultura común, la cultura de la clase trabajadora y sus prácticas”.
} 
lente que leve em consideração o contexto e a conjuntura do que está analisando, reconhecendo assim as diferenças culturais que, inevitavelmente, são atravessadas pelas relações de poder. Para o autor:

[...] o importante é assumir um posicionamento, situado num campo interdisciplinar, que busque compreender, evidenciar e intervir, a partir de um enfoque contextual, sobre determinadas articulações entre o cultural e o político, tornando explícito que sua problemática está constituída nos cruzamentos entre cultura e poder (ESCOSTEGUY, 2018, p. 110).

Apesar de ter essa posição sobre cultura que dialoga com os Estudos Culturais provenientes da Escola de Birmingham e desenvolvidos, essencialmente, por E.P.Thompson, Richard Hoggart, Raymond Williams e Stuart Hall, Martín-Barbero rejeita a afirmação de que pertence aos "estudos culturais latino-americanos". O autor afirma: "nós fazíamos estudos culturais muito antes que essa etiqueta aparecesse" (MARTÍN-BARBERO in SPIELMANN, 1996, p. 47, tradução nossa) ${ }^{19}$. Porém, confirma que os autores da escola inglesa serviram de base para suas pesquisas:

Meu vínculo com a análise cultural emerge em torno de dois conjuntos de autores que seguem duas vertentes distintas. A primeira é marcada por Gramsci e Benjamin. [...] A segunda inicia, no final dos anos 70, com a descoberta de E. P. Thompson, Raymond Williams e Richard Hoggart. [...] Nos anos 80, as perspectivas que se gestam no Centro de Birmingham tiveram profunda influência no meu pensamento. (MARTÍN-BARBERO in BEASLEY MURRAY, 2001, p. 223, tradução nossa $)^{20}$.

O autor prefere ser situado dentro dos estudos de cultura na América Latina ou então nos estudos sobre comunicação e cultura (ESCOSTEGUY, 2018. p. 109). O mal estar causado ao autor quando é colocado dentro dos limites de apenas uma escola de pensamento, para Escosteguy (Ibdem, p. 108), é justificado pelo fato de que Martín-

\footnotetext{
19 No original: "nosostros habíamos hecho estudios culturales mucho antes de que esta etiqueta apareciera".

${ }^{20}$ No original: " My acquaintance with cultural analysis emerges around two sets of authors and follows two distinct paths. The first is marked by Gramsci and Benjamin. [...] The second path starts, towards the end of the 1970s, with my discovery of the historian E. P. Thompson, Raymond Williams and Richard Hoggart. [...] During the 1980s, the perspectives emerging from the Birmingham Centre were to have a profound influence on me".
} 
Barbero reivindica investigar a partir de teorias "que não tenham origem em contextos forâneos" e, além disso, tem receio de adotar determinados modelos teóricos oriundos dos Estudos Culturais, ou seja do Norte, sem a cautela de reconstruí-los e ressignificálos para o contexto latino-americano, no Sul. A observação da cultural feita pelo autor é abrangente e leva em consideração a produção, a circulação e a recepção/consumo cultural sem deixar de inserir nessas reflexões a política e a economia. E,

Ao mesmo tempo, propicia espaço e revela sensibilidade para objetos e problemáticas que, tradicionalmente desqualificados, adquirem estatuto científico: a telenovela, as mestiçagens entre cultura popular e cultura de massa, o reconhecimento do prazer e do ócio na vida social. Tudo isso resguardando as particularidades da realidade sociocultural da América Latina" (ESCOSTEGUY, 2018, p. 108).

Isto posto, Martín-Barbero é considerado um cartógrafo por Lopes (2018) e Marroquín (2019), condição que o próprio autor já tinha declarado no seu livro Ofício de Cartógrafo (2004), em que, logo na introdução, "faz uma reflexão sobre seus trabalhos chamando-os de cartografias e de mapas e expressando seu interesse pela condição de cartógrafo naquilo em que esse ofício possa the dizer respeito" (LOPES, 2018, p. 40). Além do que se auto declara um "cartógrafo mestiço". A justificativa para esta denominação está na maneira como o autor organizou e apresentou seu pensamento ao longo dos anos:

JMB teve a particularidade de ser um cartógrafo de seu tempo, não porque pretendia, mas porque foi o que encontrou, naquela mistura de arte e ciência, para nomear uma experiência que atravessava todas as coordenadas das quais o mundo habitou. Com lápis na mão mudou-se da Europa para a América, da filosofia para a comunicação, da modernidade para o barraco da favela pré-moderna, oral e camponesa, por um lado, mas também pós-moderna e habitada pela televisão, em constante transformação e fuga até chegar à centralidade o celular, as redes sociais e o mercado que baniram para sempre de nossas vidas a solidão, o descanso e o silêncio (MARROQUín, 2019, p. 14, tradução nossa $)^{21}$.

\footnotetext{
${ }^{21}$ No original: "JMB tuvo la particularidad de ser un cartógrafo de su tiempo, no porque se lo propusiera, sino porque fue la manera como encontró, en esa mezcla de arte y ciencia, para nombrar una experiencia que atravesaba todas las coordenadas desde las que ha habitado el mundo. Lápiz en mano se desplazó de Europa hasta América, de la filosofía a la comunicación, de la modernidad hasta la choza favela premoderna, oral, campesina por una parte, pero también postmoderna y habitada por la televisión, en
} 
O espanhol-colombiano cartografou a comunicação na América Latina considerando a mobilidade, a volatilidade e as transformações da região. Utiliza de categorias para refletir sobre a realidade em movimento, e não como algo fixo (MARROQUín, 2019). Segundo Lopes (2018, p. 40), o autor usa como estratégia teórico-metodológica a cartografia cognitiva, "própria para tempos instáveis, ambíguos, fluidos, por proporcionar a exploração e a descoberta de novos itinerários em seus permanentes riscos". Martín-Barbero usa a cartografia para representar e construir imagens sobre relações, entrelaçamentos e caminhos complexos proporcionados pela comunicação, principalmente, isso se dá por meio dos mapas. A utilização da cartografia "como instrumento para prover mapas cognitivos que orientam a percepção de um espaço de pesquisa, é uma ferramenta epistemológica usada por JMB ao longo de forma permanente, mas difusa e intersticial" (LOPES, 2018, p. 42).

A cartografia é considerada um método rizomático por Deleuze e Guattari (1995 [1980]), sendo o rizoma:

[...] um modelo descritivo de uma formação que se opõe a construções lineares e hierárquicas. É o esquema de uma proliferação, ou de uma conectividade nômade, que não tem centro e se irradia em todas as direções; cada elemento pode cruzar-se com outro, influenciando ou modificando-o. Caracteriza-se pela multiplicidade, pela heterogeneidade e por delinear-se como resistência às tradicionais árvores do conhecimento (GOMES, 2014, p. 381).

Deleuze e Gattari (1995 [1980], p. 11) afirmam que "um rizoma pode ser rompido, quebrado em um lugar qualquer, e também retoma segundo uma ou outra de suas linhas e segundo outras linhas" e que as multiplicidades também são rizomáticas. Para eles, o mapa faz parte de um rizoma:

O mapa não reproduz um inconsciente fechado sobre ele mesmo, ele o constrói. Ele contribui para a conexão dos campos, para o desbloqueio dos corpos sem órgãos, para sua abertura máxima sobre um plano de consistência. Ele faz parte do rizoma. O mapa é aberto, é conectável em todas as suas dimensões, desmontável, reversível, suscetível de receber modificações constantemente. Ele pode ser rasgado, revertido, adaptar-se a montagens de qualquer natureza, ser preparado por um indivíduo, um grupo, uma formação social. Pode-se desenhá-lo numa

constante transformación y fuga hasta llegar a tener al centro el celular, las redes sociales y el mercado que desterraron por siempre de nuestras vidas la soledad, el descanso y el silencio". 
parede, concebê-lo como obra de arte, construí-lo como uma ação política ou como uma meditação. Uma das características mais importantes do rizoma talvez seja a de ter sempre múltiplas entradas; [...]. (DELEUZE e GATTARI (1995 [1980], p. 15).

Por conseguinte, a cartografia tem a característica de ser aberta, tornando-se adequada à pesquisa de Martín-Barbero, devido à geração de:

[...] um contexto propício ao cruzamento de autores e conceitos provindos de diferentes áreas do conhecimento, configurando um interessante campo de experimentações da transdisciplinaridade em seu sentido mais amplo, ou seja, em termos de um entrecruzamento entre referências e formas de pensar de diferentes domínios disciplinares, e não apenas da justaposição de resultados ou práticas metodológicas de diversos cientistas (LOPES, 2018, p. 46).

Ainda segundo Lopes (2018, p. 41), o autor espanhol-colombiano recorreu à pesquisa cartográfica ao longo de todo o seu complexo estudo de comunicação na América Latina, repleto de movimentos que avançam e recuam, "o que torna cada vez mais difícil desentranhar dado os diferentes níveis de análise que entrelaça (filosófico, comunicacional, cultural, histórico etc.) e os inúmeros objetos que vai incluindo (telenovela, jovens, educação, cidade, políticas culturais, mídias, entre muitos outros).

Esta diversidade de fonte de saberes e objetos investigados por Martín-Barbero faz com que a Comunicação seja pensada de uma maneira peculiar e ampla pelo autor. Em uma entrevista a Huergo e Morawicki (2018, p .141), o próprio afirmou quando se deu conta da completude de sua obra: "[...] houve dois professores jovens, acredito que um boliviano e um chileno, que fizeram uma palestra dizendo que 'a teoria latinoamericana de comunicação é a 'teoria da mediação', pois era a que lhes permitia pensarem-se como atores e não como comentaristas". Lopes estabelece uma nominação para a concepção do autor sobre a Comunicação:

[...] o pensamento comunicacional de Martín-Barbero não se conforma a uma teoria da recepção nem a uma teoria das mediações, mas constitui uma teoria da comunicação específica, caracterizada por uma epistemologia, metodologia e conceitos próprios, a que denominamos teoria barberiana da comunicação (LOPES, 2018, p. 39). 
É a partir desse pensamento, de que Martín -Barbero instaurou um conceito complexo e completo, denominado por Lopes (2018) de Teoria Barberiana de Comunicação que, elaboramos esta tese.

\subsection{Os Mapas das Mediações: do calafrio epistemológico às mutações culturais}

Publicado há mais de 30 anos, o livro Dos meios às mediações - Comunicação, cultura e hegemonia (MARTÍN-BARBERO, 1987) continua atual e amplamente utilizado pelos pesquisadores da Comunicação. Para Rincón (2018, p. 72), a obra “[...] nos obrigou a "abandonar" o midiacentrismo, o norte-americanismo e os dualismos morais de direita e esquerda. Inventou-se o termo mediações para articular o popular com o industrial e com o político". Couldry (2018, p. 37) cita a unicidade do livro:

Na história das investigações sobre os meios de comunicação existem poucas obras que se aproximam da riqueza de pensamento oferecida pelo mencionado livro de Jesús Martín-Barbero. E absolutamente nenhum deles demonstra, do mesmo modo, seu sensível reconhecimento das realidades do poder social.

Conforme Martín-Barbero o livro originou-se do que ele chama de "calafrio epistemológico", experiência causada quando ele e um grupo de seus estudantes estavam assistindo a um "dramalhão mexicano" em um cinema de um bairro popular de Cali, na Colômbia. O filme intitulado La ley del monte estava sendo assistido, numa sessão no final da tarde, e a plateia era majoritariamente composta por homens. Enquanto eles "choravam de emoção" e soluçavam, Martín-Barbero e seus estudantes achavam o filme de péssimo gosto e davam gargalhadas. Quase foram expulsos do cinema pelos espectadores. Assim o descreve:

Saí do cinema traumatizado, completamente traumatizado. Foi aí que nasceu Dos meios às mediações. O verdadeiro calafrio epistemológico veio ao perceber que havia visto outro filme, e o que precisava era aprender a analisar o que eles, os outros, viam. Insultar as pessoas comuns por sua ignorância não ajudava em nada a transformar a sociedade. E isso foi o que me levou a ver com as pessoas o que elas gostam. Que é a única maneira de sair de nosso mundinho e nos aproximarmos de seus mundos de vida (MARTÍN-BARBERO, 2018, p. 150-151). 
A partir daí, o autor começou a "ver com os outros" (MARTÍN-BARBERO e CORONA BERKIN, 2017), ou seja, "pensar a imagem a partir de uma perspectiva mais inclusiva, pensada para que ninguém fique de fora" (PEREIRA, 2018, p. 208). Segundo Rincón (2018), o calafrio epistemológico fez Martín-Barbero mudar o lugar das perguntas e dos olhares para fazê-los também a partir do ponto de vista do outro. Desta maneira, "mirar a partir do outro lado: desde o que as pessoas fazem com o que leem, com o que veem, com o que escutam" (LAVERDE TOSCANO E ARANGUREN DÍAZ, 1997, p. 154). Lopes (2018, p. 43) acrescenta que o calafrio epistemológico ainda "permitiu descobrir uma estética no popular, isto é, uma experiência estética não redutível ao mero reflexo, ou à resistência e a percepção de estéticas do popular muito diversas do massivo ou do culto".

Logo, "a comunicação se tornou questão de mediações mais do que de meios, questão de cultura e, portanto, não só de conhecimentos, senão de re-conhecimento" (MARTIN-BARBERO, 2009b, p. 28). Esta mudança de eixo de debate foi “" [...] para as articulações entre as práticas de comunicação e movimentos sociais, para as diferentes temporalidades e para a pluralidade de matrizes culturais" (Ibdem, p. 261). Com isso, o autor também propôs o abandono do mediacentrismo, isto é, a descentralização da análise dos meios de comunicação apenas como mero aparatos técnicos. Era preciso expandir o olhar para a experiência da vida cotidiana:

Assim, surge uma comunicação liberada dos meios de comunicação e de seus efeitos, no qual o importante é o processo no qual as comunidades produzem, circulam, questionam, mantêm e transformam significados; uma comunicação feita mais de gente do que de tecnologias ou meios (RINCÓN, 2018, p. 67).

Portanto, em Dos meios às mediações - comunicação, cultura e hegemonia (1987), Martín- Barbero aprimorou as observações acerca da mídia e ainda "conseguiu encontrar uma palavra que realmente resume seu pensamento revolucionário: “mediações" (COULDRY, 2018, p. 37). A comunicação, para o autor, é entendida então como um conjunto de práticas sociais, sendo a mediação o elo de ligação entre a comunicação e a cultura. Mas "o conceito de mediações é tão complexo que Martín- 
Barbero não oferece uma definição clara" (SIFUENTES, 2010, p. 20), o que é explicitado por ele:

Mediações remete, então, mais ao traço que conecta em rede os pontos e linhas dispersos, distintos e distantes que tecem um mapa que a uma realidade que se constata ou a um conceito que se têm e se manipula. Daí, minha tenaz resistência a definir mediações, e minha aposta por ir desdobrando-as e delimitando-as à medida que os processos de comunicação, as práticas culturais e os movimentos sociais iam se tornando aproximando, por meio da densa relação do mundo da produção midiática nas indústrias culturais com os mundos do consumo massivo, sim, mas diferenciado, ativo e cidadão (MARTÍNBARBERO, 2010, p. 29, tradução nossa $)^{22}$.

Apesar disso, Martín- Barbero (2009b) afirma que estuda as mediações a partir do conceito de mediação proposto por Martín- Serrano (1977), em que é definida por ser a atividade de controle social que impõe limites, por meio de um sistema de ordem, na produção do real frente à audiência dos meios de comunicação. Dessarte, para o autor espanhol-colombiano, as mediações são uma instância cultural que se articulam entre diferentes matrizes culturais, podendo ser os meios, os atores sociais, os espaços e os gêneros comunicacionais. E, com base nelas, os receptores produzem sentido e se apropriam do processo comunicativo. Para Jacks e Escosteguy (2005), as mediações existem para que se escape do dualismo e seja superada a simples dicotomia entre produção e recepção/consumo.

As medições, então, estão inseridas nas práticas sociais cotidianas dos sujeitos e são os lugares que estão entre a produção e a recepção:

As mediações são esse lugar de onde é possível compreender: o que se produz na televisão não responde unicamente a requisitos do sistema industrial e a estratégias comerciais, se não também a exigências que

\footnotetext{
${ }^{22}$ No original: "Mediaciones remite entonces más al trazo que pone en red los dispersos, distintos y alejados, puntos y líneas que tejen un mapa que a una realidad que se constata o a un concepto que se tiene y se maneja. De ahí mi tenaz resistencia a definir mediaciones, y mi apuesta por irlas des-plegando y acotando a medida que los procesos de comunicación, las prácticas culturales y los movimientos sociales iban haciéndose cercanos mediante la puesta en relación densa del mundo de la producción mediática en las industrias culturales con los mundos del consu mo,masivo sí pero diferenciado, activo y ciudadano".
} 
vêm da trama cultural e dos modos de ver (MARTÍN-BARBERO, 1992. p.20) $)^{23}$.

Lopes (2018, p. 51), após fazer um acompanhamento temporal do conceito, afirma que:

- as mediações são inicialmente vistas como uma perspectiva de investigação sobre e a partir da recepção;

- se afirma progressivamente a importância das mediações para uma teoria da comunicação;

- não há uma definição única de mediação;

- mediação é uma noção plural: Mediações.

Por conseguinte, toda a investigação que segue a premissa comunicacional de Martín-Barbero, assim como nós seguimos, toma como ponto de partida a cultura, as mediações e os sujeitos a partir da pluralidade das práticas de comunicação e matrizes culturais (COGO, 2007, p.2). O autor espanhol-colombiano indica como o sincretismo, a mestiçagem e a hibridação elucidam os "processos de apropriação, adaptação e vocalização culturais na mediação entre prática cultural, cultura popular, meios de comunicação democráticos e política" (GOLDING; FERGUSON, 1997, p. xvii apud ESCOSTEGUY, 2010, p. 57).

Estudar a comunicação sob a perspectiva das mediações significa entender que, entre a produção e a recepção, existe um espaço em que a cultura cotidiana se concretiza (PEREIRA, 2015, p. 43). E, conforme já afirmamos, o nosso trabalho versa sobre a recepção de telenovela e pactuamos da mesma ideia de Martín-Barbero (2002, p. 54) de que o estudo de recepção "quer resgatar a vida, a iniciativa, a criatividade dos sujeitos, quer resgatar a complexidade da vida cotidiana como espaço de produção de sentido, o caráter lúdico e libidinal na relação com os meios". A recepção não deve ser

\footnotetext{
${ }^{23}$ No original: "Las mediaciones son ese lugar desde donde es posible compree: ló que se produce en la televisión no responde unicamente a requerimientos del sistema industrial y a estratagemas comerciales sino tambíen a exigencias que vienen de la trama cultural y los modos de ver".
} 
compreendida como análise fragmentária de um dos polos do sistema comunicativo (produção, mensagem, meio, audiência), e sim como um processo complexo (LOPES, BORELLI e RESENDE, 2002). Mesmo que se tenha escolhido um recorte para ser enfocado, como é o nosso caso com a recepção, deve-se levar em consideração toda a cadeia no momento da análise. Nesse sentido, “a recepção é parte tanto de processos subjetivos quanto objetivos, de processos micro, controlados pelo sujeito, e macro, relativos a estruturas sociais e relações de poder que fogem ao seu controle" (MARTÍNBARBERO, 2002b, p.14, grifos do autor).

Portanto, o processo de recepção deve ser estudado a partir da problematização do contexto social e cultural em que está inserido, e a cultura não pode ser pensada separada das suas relações com a sociedade. Conforme já dito por mim em outro lugar (PEREIRA, 2015), Martín-Barbero concebe que a recepção não acontece apenas o momento em que se está assistindo à televisão, e sim é um processo que ocorre antes e depois dessa ação, por isso, deve ser analisada dentro de um espaço mediado. Além do mais, cada ator social lê e interpreta as mensagens dos meios de comunicação de acordo com o seu modo de viver na sociedade e "os diferentes modos de ler as mensagens estão muito ligados às tradições, preocupações e expectativas da vida prática de cada um" (LOPES, 1997. p. 166).

\subsubsection{Os mapas teórico-metodológicos das mediações}

Martín-Barbero propôs quatro mapas ao longo da sua obra, que evoluem e se complementam com o passar dos anos. Segundo Lopes (2014), é de suma importância que sejam acompanhadas tais modificações realizadas nestes mapas, já que são abertos e estão o tempo todo em movimento e seguem as permanentes transformações da comunicação e da sociedade.

Desse modo, o primeiro mapa de Martín-Barbero (1987) possibilitava enxergar as relações e a lógica do poder que sustentam o funcionamento dos meios de comunicação, que, naquele momento, para o autor, era a televisão (LOPES, 2018). Nesse primeiro mapa, Martín-Barbero (1987) sugere três lugares de mediação que interferem e alteram a maneira como os receptores recebem e interpretam os conteúdos midiáticos, que são a cotidianidade familiar, a temporalidade social e a competência cultural. A cotidianidade é definida como o espaço em que as pessoas mostram verdadeiramente como são, onde se confrontam através das relações sociais e da interação com as instituições. É uma das 
mais importantes mediações, já que a família, mesmo com as constantes mudanças propiciadas pela acessibilidade móvel e remota, ainda é a unidade básica de audiência. Representa também um lugar de conflitos e tensões que, reproduzindo as relações de poder da sociedade, faz com que os indivíduos manifestem seus anseios e inquietações mais sinceros (PEREIRA, 2015, p. 43). Ademais, tal mediação pode ser relacionada às instâncias de produção quando são "[...] capazes de simular presença e proximidade, uma relação de contato e distância [...]" (GIRARDI JÚNIOR, 2018, p. 161), percebida, por exemplo, pela verossimilhança e realismo apresentados na telenovela.

A temporalidade social é a mediação que contrapõe o tempo do cotidiano (tempo repetitivo) ao tempo produtivo (tempo valorizado pelo capital, que se pode medir) bem como a televisão, que também é organizada pelo tempo da repetição e do fragmento (por meio da grade de programação), incorporando-se assim ao cotidiano e à rotina dos receptores. Já a mediação competência cultural é como se fosse um letramento audiovisual proporcionado pelos meios através de suas narrativas (GIRARDI JÚNIOR, 2018) e ainda "[...] se refere a toda vivência cultural que o indivíduo adquire ao longo da vida, não apenas através da educação formal, mas por meio das experiências adquiridas em seu cotidiano" (PEREIRA, 2015, p. 43). Lopes, Borelli e Resende (2002, p. 40), afirmam que no processo de recepção de telenovela, a mediação "deve ser entendida como processo estruturante que configura e reconfigura tanto a interação dos membros da audiência com os meios, como a criação por parte deles dos sentidos dessa interação".

Então, as primeiras mediações estavam inseridas no primeiro mapa elaborado pelo autor, em todos os espaços compreendidos entre as Lógicas de Produção, os Formatos Industriais, as Matrizes Culturais e as Competências de Recepção. Por ser um processo que ocorre tanto no eixo diacrônico (Matrizes Culturais e Formatos Industriais) quanto sincrônico (Lógicas de Produção e Competências da Recepção), tais mediações não têm lugar fixo para serem localizadas. Importante salientar que a comunicação, a cultura e a política aparecem como central e constitutivas, não podendo ser deslocadas uma das outras por estarem inter-relacionadas. Elas estão presentes em todos os Mapas. Segue o primeiro mapa elaborado pelo autor. 
Figura 2: Primeiro Mapa das Mediações Culturais da Comunicação - 1987

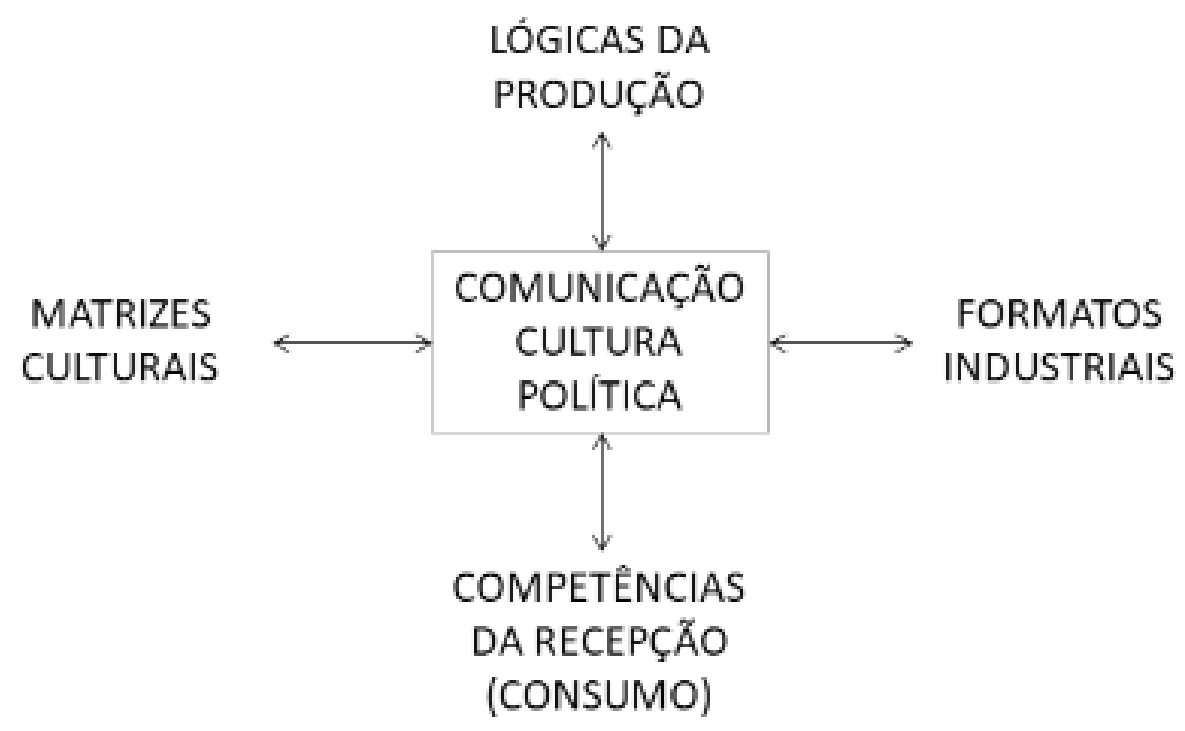

Fonte: Martín- Barbero (1987)

Poucos anos depois do primeiro mapa, em De los medios a las practicas (1990), Martín-Barbero sugere que esses três lugares de mediação citados acima (cotidianidade familiar, temporalidade social e competência cultural) sejam convertidos em quatro diferentes dimensões: socialidade, ritualidade, institucionalidade e tecnicidade. No entanto, o autor não relacionou os termos cotidianidade familiar, temporalidade social e competência cultural com essas novas mediações propostas (RONSINI,2011). Segundo Lopes (2018), foi nessa etapa em que a complexa teoria das mediações do autor ultrapassou a configuração de uma teoria apenas da recepção. Houve o deslocamento do estudo das mediações culturais da comunicação para o estudo das mediações comunicativas da cultura, e Martín-Barbero, então, repensou a comunicação dando a ela maior densidade teórica (LOPES, 2018). Portanto:

A presença dos meios na vida social, não em termos puramente ideológicos, mas como uma capacidade de ver além dos costumes, ajudando o país a se movimentar. Isso me leva a dar mais um passo, junto com a aparição massiva, em meados de 1990, do computador e do que veio rapidamente com ele. Inverto meu primeiro mapa e proponho as "mediações comunicativas da cultura", que são: a "tecnicidade"; a "institucionalidade" crescente dos meios como instituições sociais e não apenas aparatos, instituições de peso econômico, político, cultural; a "socialidade" - como o laço social está se transformando para os jovens, como as relações entre pais e 
filhos, e entre casais, estão mudando [...]. E, finalmente, as novas "ritualidades" que acontecem em relação aos novos formatos industriais possibilitados pela tecnicidade (MARTÍN-BARBERO, 2009, p. 151-152).

A mediação socialidade é o espaço onde se estabelecem as relações sociais bem como as subjetividades compostas por estas relações que interferem no contato dos atores com o mundo social e, também, com a mídia. Tal mediação é um lugar:

de ancoragem da práxis comunicativa e resulta dos modos e usos coletivos de comunicação, isto é, de interpelação/constituição dos atores sociais e de suas relações (hegemonia/contra hegemonia) com o poder (MARTÍNBARBERO, 2009b, p. 17).

A socialidade contribui para a constituição das identidades e das formas de interação dos sujeitos (RONSINI; SILVA; WOTTRICH, 2009) e seus "referentes individuais, de gênero, etnia e geração que são estruturados a partir de uma posição de classe" (RONSINI, 2011, p. 91). É o contexto social e histórico que faz com que os sujeitos definam suas posições, atitudes e comportamentos no âmbito da recepção midiática. Isto é explicado através da Sociologia de Reprodução de Bourdieu:

[...] as relações sociais são pensadas a partir da noção de 'campo' bourdiana, e o papel do analista da recepção é compreender os vínculos entre a estrutura de poder que regula o processo singular de dar sentido aos formatos industriais (discursos, gêneros, programas e/ou grades de programação) e suas matrizes culturais (RONSINI, 2011, p. 92).

Porém, Martín-Barbero (2018, p. 176) revela que atualmente a socialidade deve ser mais trabalhada, na verdade, retrabalhada, visto que é preciso:“[...] saber como o que entendíamos por laço social está mudando". Em outras palavras, as maneiras de estarmos juntos em sociedade estão em constante mudança e as formas de sentir e estar estão sendo ressignificadas. Há novos espaços onde se faz política, como por exemplo, nas redes sociais, e novos espaços públicos são criados, tanto em nível micro quanto macro, o perto e o longe também ganham novos sentidos.

A mediação ritualidade "se refere aos diferentes usos sociais dos meios e aos diferentes trajetos de leitura" (RONSINI, 2010, p. 9) feitos pelos receptores, ou seja, são 
os modos de ver e ler os textos dos produtos midiáticos. As múltiplas trajetórias de leitura estão

[...] ligadas às condições sociais do gosto, marcadas por níveis e qualidade de educação, por posses e saberes constituídos na memória étnica, de classe, ou de gênero, e por hábitos familiares de convivência com a cultura letrada, oral ou audiovisual, que carregam a experiência do ver sobre a do ler ou vice-versa (MARTÍN-BARBERO, 2009b, p. 19).

Esses modos de ler e de ver a mídia constituem "gramáticas de ação" (MARTÍNBARBERO, 2009b, p. 19) e regulam o modo como a cotidianidade dos sujeitos interage com o tempo e o espaço dos meios de comunicação. Dessa maneira, a ritualidade "remete-nos ao nexo simbólico que sustenta toda a comunicação: à sua ancoragem na memória, aos seus ritmos e formas, seus cenários de interação e repetição" (Ibdem). Esta mediação

[...] permite pensar a modelagem dos ritmos que imprimimos ao viver cotidiano. Essa ritualidade, a que nós todos nos submetemos e ajudamos a criar, está vinculada ao triunfo da apresentação sobre a significação de modo que a simbolização do espaço (o lugar), a importância imediata dele em nossas vidas, é atravessada pela fantasia da apresentação e, assim a ritualidade instituída pela técnica dificulta a interlocução ao nos oferecer a trama agendada para discussão e suas resoluções prévias (RONSINI, 2011, p. 91).

De modo empírico, a mediação ritualidade é verificada no momento do encontro do receptor com a mídia, ou, neste caso, no momento da assistência da telenovela que se configura em um ritual em que os telespectadores, através de seus valores incorporados, colocam constantemente em jogo a significação de bens simbólicos e materiais (PEREIRA, 2015, p. 45). Martín-Barbero (2018, p. 178) reflete que na contemporaneidade, a ritualidade está passando por mudanças, por isso, deve-se pensar: "[...] como a relação com os meios e as tecnologias nos estão mudando. E como isso desloca os professores e os pais de família".

A institucionalidade é carregada de interesses e poderes, públicos e privados, que se contrapõem, afetando constantemente a regulação de discursos (PIENIZ, 2013; LOPES, 2018). Esta mediação é uma característica da sociedade midiática porque estabelece as fronteiras entre os diferentes espaços sociais, o que pode ser discutido 
tendo em vista que, na contemporaneidade comunicacional, há uma certa descrença no papel das instituições sociais (PIENIZ, 2013).

De acordo com Zanini e Sifuentes (2019, p. 248), a mediação institucionalidade diz respeito à "envergadura econômico-jurídica dos meios" de comunicação, ou seja, é "os meios e outras formas de comunicação que adquirem caráter de instituições" (MARTÍN-BARBERO, 2018, p. 174). Sob o viés desta mediação, a comunicação pode ser convertida "em questão de meios, isto é, de produção de discursos públicos cuja hegemonia se encontra hoje paradoxalmente do lado dos interesses privados" (MARTÍN-BARBERO, 2009b, p. 18, grifos do autor).

A tecnicidade não se relaciona à noção pura e simples de aparato tecnológico, mas "aponta para os modos como a tecnologia vai moldar a cultura e as práticas sociais" (RONSINI, 2011, p. 88). Remete-se à construção de novas práticas através das diferentes linguagens dos meios, traduzindo em formato industrial a competitividade tecnológica das empresas de comunicação e também sua competência comunicativa (RONSINI, 2012, p. 69). A problematização da tecnicidade indica a atenção que o autor dá para a convergência midiática (PIENIZ, 2013), já que ele declara: "a estratégica mediação da tecnicidade se delineia atualmente em um novo cenário, o da globalização, [...] não só no espaço das redes informáticas como também na conversão dos meios televisão e telefone - com o computador" (MARTÍN-BARBERO, 2009, p. 19).

A simultaneidade das tarefas exigida atualmente pelos meios de comunicação como "aparatos tecnoperceptivos" (RONSINI, 2012) acaba por mobilizar uma necessidade de produção e consumo voraz, instantâneo e multitela. A consequência disso, é também uma "vivência fragmentada e heterogênea tal como o ritmo das imagens nas telas da televisão e do computador" (Ibdem).

[...] o que a política perdeu de densidade simbólica - em termos do conceito de Ricoeur, essa capacidade de convocar e de fazer sentir-se juntos, a tecnologia ganhou. Isso é uma ideia minha. A tecnologia, que era vista como puro instrumento, se encheu de densidade cultural e simbólica (MARTÍN-BARBERO, 2018, p. 176).

Tal mediação é definida também como o estatuto social da técnica, a competência de linguagem (MARTÍN-BARBERO, 2004). É a materialidade no discurso remetendo à constituição de gramáticas que dão origem aos formatos midiáticos, recuperando assim 
o sentido original do termo grego techné (que significa saber fazer, habilidade de expressar através de formas materiais). Simboliza outras dimensões do espaço na medida em que na contemporaneidade, a sociedade globalizada adotou um modelo técnico unificado que supre a demanda da recepção/consumo, mas também busca o lucro para as empresas de comunicação.

Assim, o segundo e também mais utilizado mapa de Martín-Barbero pelos pesquisadores de comunicação ficou configurado da seguinte maneira:

\section{Figura 3 - Segundo Mapa Teórico-Metodológico das Mediações Comunicativas da Cultura - 1998}

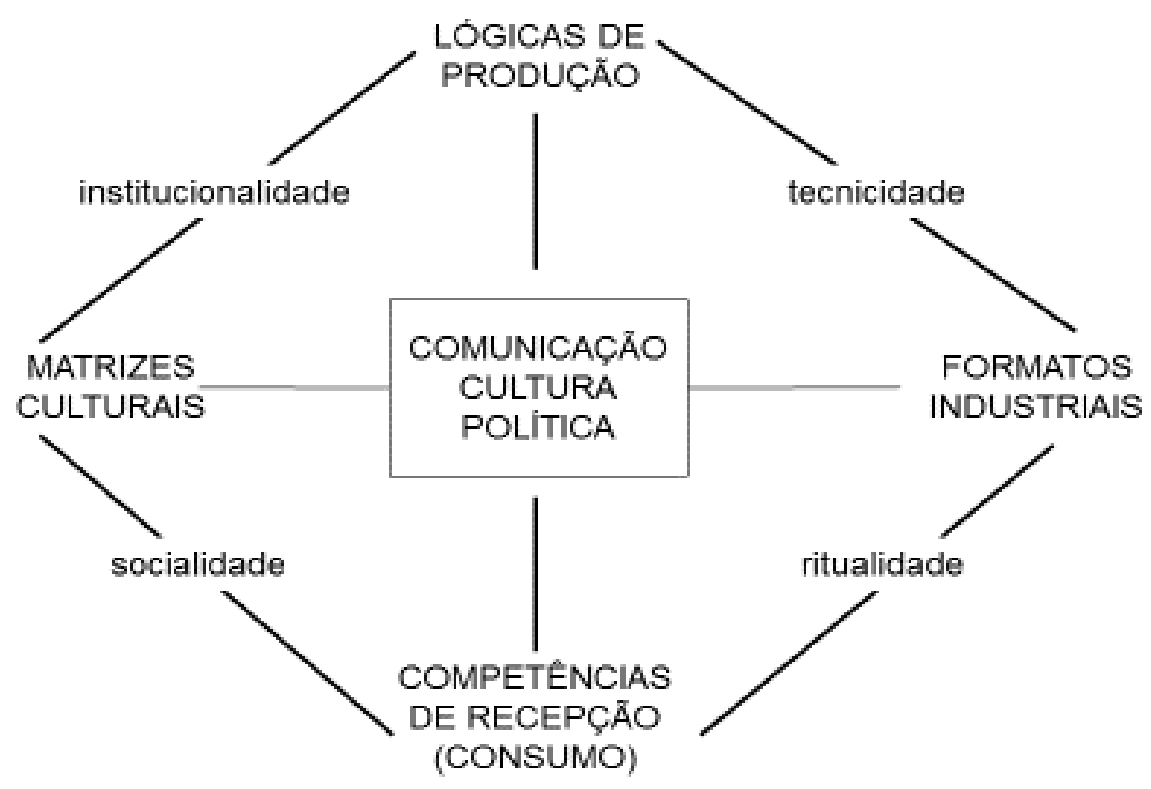

Fonte: Martín-Barbero (2009b)

Com este segundo mapa, "é possível operacionalizar a análise de qualquer fenômeno social que relaciona comunicação, cultura e política, impondo-se como uma dimensão da articulação entre produtores, mídia, mensagens, receptores e cultura" (LOPES, 2018, p. 54). Assim, a comunicação é a mediadora das mais variadas formas da vida cultural e política.

Martín-Barbero retoma a discussão acerca das mediações com o intuito de ampliar e redefinir a abrangência teórica do conceito face ao contexto contemporâneo e globalizado de comunicação. Propõe, então, a substituição das mediações 
institucionalidade e socialidade por identidade e cognitividade, respectivamente. Isto porque, entende que nossa sociedade atual, com a "mutação tecnológica passou a configurar um novo ecossistema comunicativo" (MARTÍN-BARBERO, 2010, p. 222). De tal forma que o autor vincula esse novo mapa de investigação das mutações culturais contemporâneas em que os eixos são a temporalidadelformas de espaço e mobilidadelfluxos. Martín-Barbero retoma e atualiza a temporalidade proposta no primeiro mapa. Para Lopes (2014, p. 72), a temporalidade contemporânea:

configura a crise da experiência moderna do tempo, que se manifesta na transformação profunda da estrutura da temporalidade, no culto ao presente, no debilitamento da relação histórica com o passado e na confusão dos tempos que nos prende à simultaneidade do atual.

As temporalidades vividas por cada sociedade são heterogêneas, pois é possível conviver tanto com formações culturais arcaicas, quanto residuais e até emergentes (MARTÍN-BARBERO, 2002). O autor reflete, então, sobre múltiplas temporalidades:

Múltiplas temporalidades, entendidas como mediações das ações que os meios de comunicação, e que se articulam com diferentes espacialidades - o bairro, a cotidianidade familiar, as culturas populares urbanas e massivas, etc - contribuem a esse processo de reconfiguração ao evidenciar o processo de apropriação dos textos a partir dos usos, do consumo e das práticas nas quais os sujeitos estão envolvidos (ROCHA e ROCHE, 2019, p. 72, tradução nossa) ${ }^{24}$.

Ainda de acordo com Rocha e Roche (2019), neste novo mapa, a temporalidade deixou de ser uma mediação específica, mas é considerada como uma categoria transversal que acaba por atravessar todas as outras. A partir disso, Martín-Barbero (2009b) argumenta a favor da importância de se analisar a relação histórica que marca o trânsito entre os formatos industriais e as matrizes culturais, assumindo a investigação do que muda historicamente na articulação entre os discursos públicos e os movimentos sociais e os modos de produção do público.

O tempo na contemporaneidade faz com que o passado e o futuro sejam reconfigurados, e são a conectividade, o fluxo e a informação que preenchem esse

\footnotetext{
${ }^{24}$ No original: "Múltiples temporalidades, entendidas como mediaciones de la acción de los medios de comunicación, y que se articulan con distintas espacialidades - el barrio, la cotidianidad familiar, las culturas populares urbanas y masivas, etc-contribuyen a ese proceso de reconfiguración al evidenciar el proceso de apropiación de los textos a partir de los usos, del consumo y de las prácticas en las cuales los sujetos están involucrados."
} 
chamado "tempo-agora" (ROCHA e ROCHE, 2019). Nele, "a memória que assume o comando da tradição não é a que nos move para um tempo imóvel e sim a que faz visíveis os destempos, ou seja, a que faz presente um passado que nos desestabiliza" (MARTÍN-BARBERO, 2017b, p. 26, tradução nossa) ${ }^{25}$. Martín-Barbero (2018, p. 26, grifos do autor) ainda associa à temporalidade atual o que chama de "culto ao presente", que faz com que a simultaneidade acabe por confundir os tempos, alimentando-se "especialmente do enfraquecimento do passado e da bricolage dos tempos que nos familiarizam com qualquer outro tempo sem esforço, arrancando as complexidades e ambiguidades de seu tempo".

Já a espacialidade, como o nome mesmo já remete, significa estar presente nos mais variados espaços, sendo eles:

[...] o espaço habitado do território feito de proximidade e pertencimento, o espaço comunicacional que as redes eletrônicas tecem, o espaço imaginado da nação e de sua identidade, o espaço da cidade moderna com a subjetividade que emerge da nova relação com a cidade, dos modos de sua apropriação" (LOPES, 2014, p. 73).

Assim, os espaços e territórios são pensados no plural, pois eles entram em contato uns com os outros nessa nova configuração de mundo globalizado em que vivemos. É a espacialidade um dos eixos centrais da nossa contemporaneidade, já que o tempo está cada vez mais veloz e dinâmico com as novas tecnologias. A espacialidade associada à temporalidade é considerada por Felippi, Villela e Silveira (2019), mediação central para a compreensão do novo e atual "entorno comunicativo".

A mobilidade é definida pelo trânsito ininterrupto das migrações populacionais, mas também dessas migrações entendidas como deslocamentos que ocorrem a partir do contato das pessoas com a internet, causando, assim, "[...] o aparecimento das novas figuras de sensibilidade" (LOPES, 2018, p. 57). Por isso essa mediação tem estreita relação com a mediação que Martín-Barbero (2010) denominou de fluxos, sendo esses de imagens, virtuais, de informação e de pessoas. O autor "reforça o sentido de um ecossistema, um entorno em que transitam estes fluxos de imagens e de informação numa relação direta com sentidos demográficos” (GOMES et al. 2017/2018, p. 141).

\footnotetext{
${ }^{25}$ No original: "la memoria que se hace cargo de la tradición no es la que nos traslada a un tiempo inmóvil sino la que hace visibles los des tiempos, o sea la que hace presente un pasado que nos desestabiliza".
} 
Para Lopes (2014), tais fluxos migratórios acabam por ocasionar desordens sociais e políticas na cidade, e os de mídia, uma desestabilidade na cultura escolar e letrada devido ao fato de que a tecnologia digital desloca os saberes e altera os estatutos cognitivo e institucional, fazendo com que desapareçam gradualmente as fronteiras "entre razão e imaginação, saber e informação, arte e ciência, saber especializado e conhecimento comum” (LOPES, 2014, p. 73).

A identidade sempre foi relevante nas discussões de Martín-Barbero, pois foi uma mediação presente desde o princípio (SIFUENTES e ZANINI, 2019). Mas foi apenas neste penúltimo mapa que o autor de fato inseriu a identidade como mediação:

Quando a sociedade não tem centro, as identidades que eram o centro do sujeito também deixam de sê-lo. Até Habermas admite que já não é possível falar de apenas uma identidade do indivíduo porque seus referentes das identidades também explodem. Era preciso acompanhar como estavam se transformando as maneiras de sentir, o laço social que religa uns a outros, porque esta é a dimensão que fala na identidade (Martín-Barbero, 2009, p. 153).

Martín-Barbero (2003b, p. 38) afirma que uma das consequências desse novo contexto das mutações tecnológicas são as "explosões e implosões das identidades", já que elas estão se transformando. $\mathrm{O}$ autor também relaciona a identidade com a tecnologia, sendo ambas dependentes entre si e complementa: "dois processos estão transformando radicalmente o lugar da cultura nas nossas sociedades: a revitalização das identidades e a revolução das tecnicidades" (Ibdem, p. 54). Ele menciona três eixos de investigação para pensar as identidades na contemporaneidade: as contradições entre identidades e fluxos de globalização, as mudanças de profundidade na percepção e no sentido das identidades e o caráter constitutivo que têm as narrativas identitárias (SIFUENTES e ZANINI, 2019).

É importante ressaltar que, para Martín-Barbero (2006), a identidade é a expressão daquilo que dá sentido e valor à vida de um indivíduo. E, na atualidade, as identidades culturais (étnicas, raciais, locais e regionais) são protagonistas de inúmeros e complexos conflitos (SIFUENTES e ZANINI, 2019, p. 250, tradução nossa), porém, "assim como a busca por reconhecimento de identidade gera divisão e embate, proporciona também laços sociais notáveis, muitos firmados para além das fronteiras 
nacionais - como os de gênero e idade-, reconfigurados em tempos de redes"26. Portanto, para compreender as questões de identidade no cenário atual, é necessário problematizar essas tensões entre ruptura e aproximação. Assim:

Até pouco tempo, falar de identidade era falar de raízes, isto é, de costumes e território, de tempo longo e de memória simbolicamente densa. Disso e somente disso estava feita a identidade. Mas falar de identidade hoje implica também - se não quisermos condená-la ao limbo de uma tradição desconectada das mutações perceptivas e expressivas do presente - falar das migrações e mobilidades, de redes e de fluxos, de instantaneidade e de fluidez (MARTÍN-BARBERO, 2006, p. 61).

Há, na contemporaneidade, além de novas identidades, também novas cognitividades e estas estão imersas tanto na mediação socialidade quanto na ritualidade (RONSINI, 2010). Além do que a identidade e a cognitividade têm estreita relação:

[...] dificilmente o conjunto de fatores, como valores, crenças e emoções que influem no processo de aquisição de conhecimentos ou informações pode ser visto separadamente da noção de identidade, assim como a noção de subjetividade entendida como o processo de constituição do eu. (RONSINI, 2010, p. 8).

Segue então, este terceiro mapa proposto pelo investigador:

\footnotetext{
${ }^{26}$ No original: “ así como la búsqueda de reconocimiento de identidad genera división y embate, propicia también lazos sociales notables, muchos afirmados más allá de las fronteras nacionales -como los de género y edad-, reconfigurados en tiempos de redes".
} 
Figura 4: Terceiro Mapa Teórico-Metodológico das Mediações: Mutações Comunicativas e Culturais - 2010

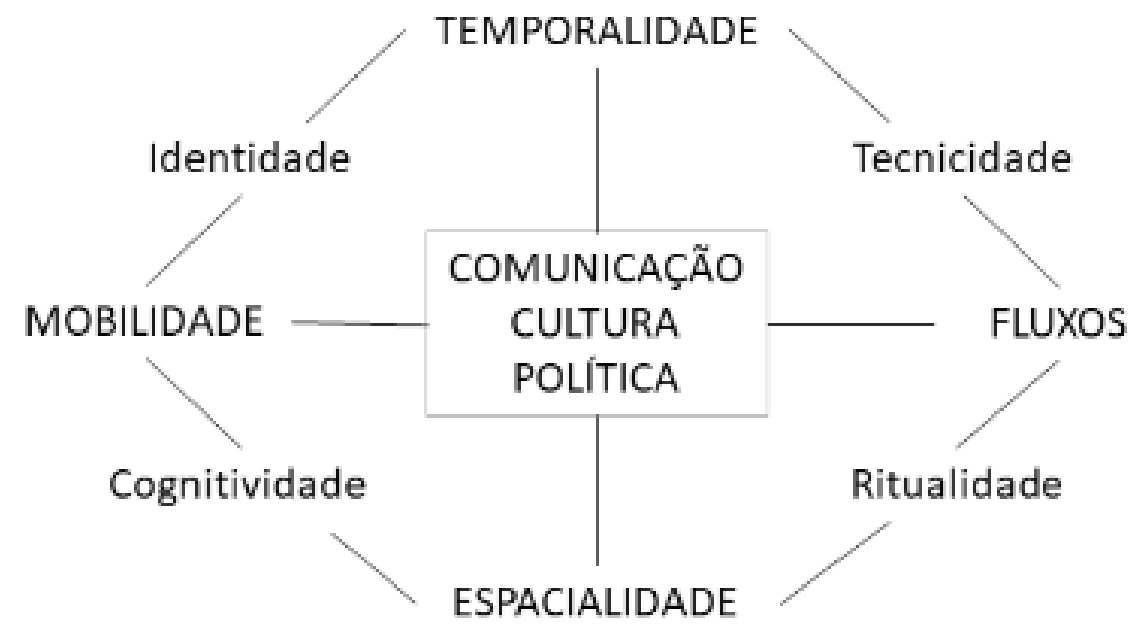

Fonte: Martín-Barbero (2010)

Recentemente, em julho de 2017, durante uma entrevista a Omar Rincón, MartínBarbero apresentou um quarto mapa, ainda pouco discutido no cenário acadêmico latino-americano. Esse novo mapa tem o objetivo de "investigar el sensorium contemporáneo" (MARTÍN-BARBERO, 2017), em que o autor propõe novas mediações e reposiciona no mapa algumas das antigas já discutidas por ele. Os novos eixos são tecnicidades/sensorialidades e as mediações adicionadas são narrativas, redes e cidadanias. Lopes (2018, p. 59) afirma que este novo mapa é "rizomático em que essas mediações se tornaram básicas e se despregam podendo ser relacionadas em formas de direções e densidades diferentes". O que fica claro é que elas foram organizadas de maneira que o processo comunicativo continue suprindo as demandas exigidas pelo novo ecossistema pautado em grande parte pelas tecnologias digitais. Desta forma:

Esse novo mapa para investigar a mutação cultural, expressa os modos como JMB é um criador de teorias, de olhares, de compreensões sobre a realidade política e cultural que no habita. Sua obsessão para sair de posturas maniqueístas, dando densidade cultural, social e política à cultura e à comunicação, mudar o olhar acadêmico para o ver com e a partir dos outros. Se o mundo muda, os olhares à esse mundo também. 
Nessa nova cartografia que propõem, Martín-Barbero usa duas figuras como chaves para pensar nossa atualidade: sensorium e mutação cultural. (RINCÓN, 2018, p. 263, grifo do autor, tradução nossa) ${ }^{27}$.

O autor aponta para discussão sobre o contexto vivido e sua relação com os meios de comunicação, visto que para ele, os meios devem ser repensados conforme a realidade contemporânea. Afinal, não existe apenas o rádio ou a televisão que são ligados e desligados no momento em que o receptor quer, pois tudo está em circulação o tempo inteiro, inclusive com apuradas informações de audiência, por exemplo:

“ [...] entre as lógicas de produção e formatos industriais, está a mutação tecnológica: aqui estamos diante de uma mudança radical[...] Quando Castells começou a trabalhar no campo das tecnologias, em sua primeira pesquisa [...] apontou, com uma visão muito clara, que uma das transformações que se precisava ter em conta é que os meios já não eram pontuais, mas transversais. Uma coisa é quando desligas e ligas o rádio e pronto, e outra coisa é quando tu passas informação de teu filho pequeno, que colocaste no jardim infância para que as professoras saibam de sua saúde, de seus traços de caráter. Essa informação fica em um computador e vai te perseguir toda a tua vida, e vai para a polícia, para os bancos... Castells está falando do início disso" (MARTÍN-BARBERO, 2018, p. 175).

Martín-Barbero discute a mediação sensorialidades a partir do conceito de sensorium proposto por Benjamin, que:

"[...] foi o pioneiro a vislumbrar a mediação fundamental que permite pensar historicamente a relação da transformação nas condições de produção com as mudanças no espaço da cultura, isto é, as transformações do sensorium dos modos de percepção, da experiência social" (MARTÍN- BARBERO, 2009b, p. 80).

\footnotetext{
${ }^{27}$ No original: "Este nuevo mapa para investigar la mutación cultural, expresa los modos como JMB es un creador de teorías, de miradas, de comprensiones sobre la realidad política y cultural que nos habita. Su obsesión para salir de posturas maniqueas, ganarle densidad cultural, social y política a la cultura y la comunicación, mover la mirada académica hacia el ver con y desde los otros. Si el mundo cambia, las miradas a ese mundo también. En esta nueva cartografía que propone, Martín-Barbero usa dos figuras como claves para pensar nuestra actualidad: sensorium y mutación cultural.
} 
O conceito de sensorium é relacionado à subjetividade, com os modos de sentir, de ver, de viver e de comunicar a partir de estímulos sonoros, imagéticos, visuais e cognitivos proporcionados pelo contexto comunicativo atual. É atribuir, por meio dos sentidos, sentido a algo que faz parte do sistema sensorial na interação com o mundo externo (JOHN, RIBEIRO e SILVA, 2019). São sensações compartilhadas, por meio da mediação, que implicam "nesses outros usos do massivo e nessas outras presenças sociais do corpo e das sensações (RINCÓN, 2018, p. 72). Rincón (2018) também afirma que a sensibilidade, atualmente, é transformada e amplificada proporcionando novos modos de percepção, novas sensações, mudando, inclusive, os modos de consumir narrativas antigas e novas, pois tudo é permeado pela sensorialidade.

Conforme John, Ribeiro e Silva (2019), o desafio proposto por Martín-Barbero no que diz respeito à sensorialidade é pensá-la como uma mediação central para a compreensão não só das relações estabelecidas pelos sujeitos com as narrativas midiáticas, mas também com o mundo em que vivem. Ou seja, refletir sobre as relações políticas e socioculturais na atualidade. Por isso o conceito não é fechado, é amplo e aberto (JOHN, RIBEIRO e SILVA, 2019) e também é relacionado ao tempo e ao espaço.

A sensorialidade está associada à tecnicidade (JOHN, RIBEIRO e SILVA, 2019), apesar de as duas serem interdependentes. Por isso, Martín-Barbero deu maior densidade teórica a essas duas mediações nesse quarto mapa (LOPES, 2018). Este último mapa demonstra com maior clareza o interesse do autor espanhol-colombiano pela teoria da sensibilidade, pois "o leva a dialogar com Rancière e a partilha do sensível" (LOPES, 2018, p. 59), além do que, assim como o francês, rechaça a redução da estética a uma reflexão especulativa porque defende "alargá-la a uma reflexão vinculada aos muito distintos regimes de sensibilidade que coexistem numa sociedade, e que o leva ao encontro de um regime que não havia sido considerado tradicionalmente estético, o do melodrama" (Ibdem).

A outra mediação recém acrescentada por Martín-Barbero é chamada de narrativas. Segundo Silva e Baseio (2019), esta mediação está relacionada com o ritual, ou seja, ao conjunto das experiências cotidianas dos atores sociais. $\mathrm{O}$ ato de pensar as narrativas requer aproximar daquilo que se repete como rotina, ritual, conflitos, surpresas, desejo, caos, um sobreposto ao outro (SILVA e BASEIO, 2019). 
Para o autor que se fez latino-americano, os recursos técnicos não remetem apenas aos formatos industriais, mas também a outros modos de narrar (SILVA e BASEIO, 2019). Assim, "o outro lado da indústria de narrativas é o que possibilita o acesso ao processo de circulação cultural materializado na literatura [...]” (Ibdem, p. 174). Martín- Barbero (2003b, p. 170) relaciona a estrutura do melodrama com a da narração, situando o melodrama como "escrito para os que não sabem ler", sendo espetáculo para o povo em um processo de (re)conhecimento. Desta forma, "[...] uma história dos modos de narrar e da encenação da cultura de massa é, em grande parte, uma história do melodrama" (MARTÍN-BARBERO, 2009b, 172).

As narrativas, neste novo contexto, têm sido recriadas por meio das novas tecnologias, passando a ser cada vez mais complexas, híbridas e componentes do fluxo comunicacional em constante atualização.

Essas transformações nas sociedades contemporâneas estão vinculadas a outra nova mediação proposta por Martín-Barbero nesse quarto mapa, as redes. Elas estão sendo continuamente incorporadas nos estudos de comunicação e cultura, incrustradas nas formas dominantes de informação, mudando as relações sociais, as sensibilidades, as narrativas culturais, enfim, criando novas maneiras de ver o mundo (BRIGNOL, COGO e MARTÍNEZ, 2019, p. 193). As redes possibilitam a comunicação em tempo real e comprimem as noções de tempo e espaço, pois, hoje, é possível comunicar-nos de um ponto a outro do mundo apenas através de um click. Com isso, '[...] as identidades e papéis sociais que estavam estritamente relacionados ao lugar físico passam a redefinirse gradualmente" (BRIGNOL, COGO e MARTÍNEZ, 2019, p. 195, tradução nossa) ${ }^{28}$ por meio da lógica dos fluxos.

É nas redes digitais que surgem novas esferas públicas e privadas, e esses espaços, muitas vezes, misturam-se sem que seja possível saber o que é de domínio público e o que é do privado, pois há um intercâmbio constante e veloz. Elas se tornam também um espaço de disputas, ocupando um lugar central na vida social e política (BRIGNOL, COGO e MARTÍNEZ, 2019).

A mediação rede demonstra a preocupação de Martín-Barbero com o papel das redes na configuração das novas relações do tempo e do espaço na atualidade:

\footnotetext{
${ }^{28}$ No original: “[...] las identidades y roles sociales que estaban estrechamente relacionados al lugar físico pasan a redefinirse paulatinamente".
} 
Como estão se transformanando as percepções do espaço? O espaço habitado ou mátria, o espaço imaginado ou pátria, o espaço produzido ou fátria - que é tudo o que tem a ver com comunicação e meios-, e o espaço praticado entre "urbanias" e cidadanias. [...] E, depois, as duas grandes perturbações: a instantânea, essa instantânea mundial, o que significam as instantâneas hoje: o mundo inteiro olhando uma imagem (MARTÍN-BARBERO, 2018, p. 178).

A convergência digital introduz esse modelo de rede, de fluxo constante, de conectividade não linear e de interações jamais vistas, proporcionando um modo eletrônico de proximidade por meio de interface (tanto pelas telas do computador quanto pelas telas dos telefones celulares). Transformam-se, assim, as dinâmicas dos espaços comunicacionais:

Nesse novo espaço comunicacional, tecido menos de encontros e multidões que de conexões, fluxos e redes, surgem novos 'modos de estar juntos' e outros dispositivos de percepção mediados pela acelerada aliança entre velocidades audiovisuais e informacionais (MARTÍN- BARBERO, 2011, p.118, tradução nossa) ${ }^{29}$.

A mediação cidadanias se faz presente no que diz respeito à problematização da ação dos meios de comunicação no campo cultural (BONIN e MORIGI, 2019). Tal mediação dá conta dos impactos e mudanças sociais causados pelo novo ecossistema comunicacional que estamos vivenciando, uma sociedade global e veloz. E mesmo que a sociedade em rede tenha trazido novas formas de abordar a cidadania, a visão tradicional não foi abandonada, e sim, ampliada por causa das interações entre máquinas e seres humanos (BONIN e MORIGI, 2019, p. 223, tradução nossa), pois esta é "um conjunto de direitos e deveres dos cidadãos". ${ }^{30}$

Martín-Barbero discute as cidadanias quando discorre sobre as relações entre os campos da comunicação e cultura, e especialmente a mediação tecnológica é convertida em componente estrutural na sociedade com a tecnicidade (BONIN e MORIGI, 2019).

\footnotetext{
${ }^{29}$ No original: “ En ese nuevo espacio comunicacional, tejido menos de encuentros y muchedumbres que de conexiones, flujos y redes, surgen nuevos 'modos de estar juntos' y otros dispositivos de percepción mediados por la acelerada alianza entre velocidades audiovisuales e informacionales".

${ }^{30}$ No original: "un conjunto de derechos y deberes de los ciudadanos".
} 
Afinal, o autor investiga a constituição de novos cidadãos vinculados ao campo cultural e ao papel dos meios digitais nesta nova constituição:

\begin{abstract}
Assim, ao mesmo tempo em que enfrentamos uma crescente onda de fatalismo tecnológico combinado com o mais radical pessimismo político, encontramo-nos ante uma mutação tecnológica que passou a configurar um novo ecossistema comunicativo. Ecossistema em que a experiência audiovisual afetada pela revolução digital aponta para a constituição de uma visibilidade cultural, cenário estratégico hoje de uma batalha política decisiva contra o velho e excludente poder da letra que ao longo de um século e meio ignorou a diferença e a riqueza das oralidades e visualidades culturais, estas que entrelaçam agora suas memórias nos imaginários da virtualidade para dar sentido novo e forma nova às tradições culturais (MARTÍN-BARBERO, 2014, p. 25).
\end{abstract}

No âmbito latino-americano, as comunidades culturais estão se reconstruindo, reinventando suas identidades, renovando seus usos e memórias, reconfigurando e articulando o global e o local. E isto tudo é observado por Martín-Barbero quando propõe a mediação cidadanias (BONIN e MORIGI, 2019), já que tais comunidades representam a emergência de novas formas de cidadania.

Isto posto, o mais recente mapa para investigar as mutações culturais coloca em voga as preocupações do autor com todo o novo ecossistema comunicacional atual, problematizando, especialmente,“ [...] o tema-chave entre a tecnologia e política; os sentidos da técnica e as figuras do sensível; visibilidades estéticas e narrativas intermidiáticas" (MARTÍN- BARBERO, 2018, p. 179). Demonstra assim, as inquietações do pensador provocadas por essa nova e complexa configuração:

Hoje, minhas preocupações reencontram as tensões entre meios e medos como um dos mais profundos traumas que atravessam nossas sociedades: no confronto dos meios com os facebooks assistimos a uma das complexidades e perversões sociopolíticas mais difíceis de analisar culturalmente (Ibdem, p. 9, tradução nossa) ${ }^{31}$.

\footnotetext{
${ }^{31}$ No original: "Hoy mis preocupaciones reencuntran las tensiones entre medios y miedos como uma de los más profundos traumas que atraviesan nuestras sociedades: en el entrechoque de los medios com los facebooks asistimos a uma de las complejidades y pervenciones sociolopolíticas más dificiles analizar culturalmente".
} 
Apresentamos, então, o quarto mapa elaborado por Martín-Barbero (2017):

\section{Figura 5 - Quarto Mapa Teórico-Metodológico - Mutações Culturais e Comunicativas Contemporâneas - 2017}

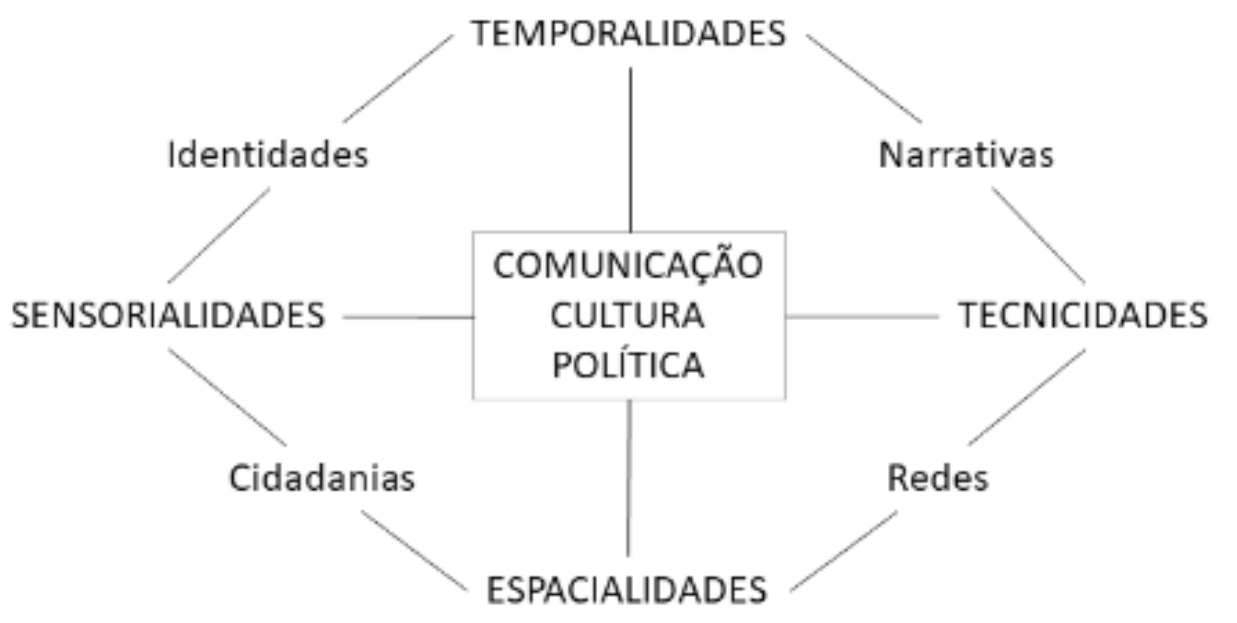

Fonte: Lopes (2018)

Assim, após a apresentação e discussão de todos os mapas elaborados por MartínBarbero, ajustamo-nos à ideia de Lopes (2018, p. 60) de que a construção cartográfica barberiana é essencialmente dialética, tendo em vista que um mapa dialoga com o outro, "portanto, um mapa não substitui o anterior, mas se apropria, o reinterpreta e o acrescenta, em um processo que exige um pensamento de maior complexidade. [...] para dar conta de uma realidade mutável e suscetível de intervenção". A autora ressalta ainda que a apropriação dos mapas pelos pesquisadores deve depender da estratégica metodológica que este resolver adotar. Com isso, é possível que se mobilize mais de um mapa, dando maior ou menor destaque a determinadas mediações e deixando de fora da pesquisa outras. Seguindo essa lógica, Silva e Baseio (2019) propuseram uma figura que ilustra com clareza essa fusão de todos os mapas e suas possíveis mobilidades: 
Figura 6: Fusão de todos os Mapas de Martín-Barbero

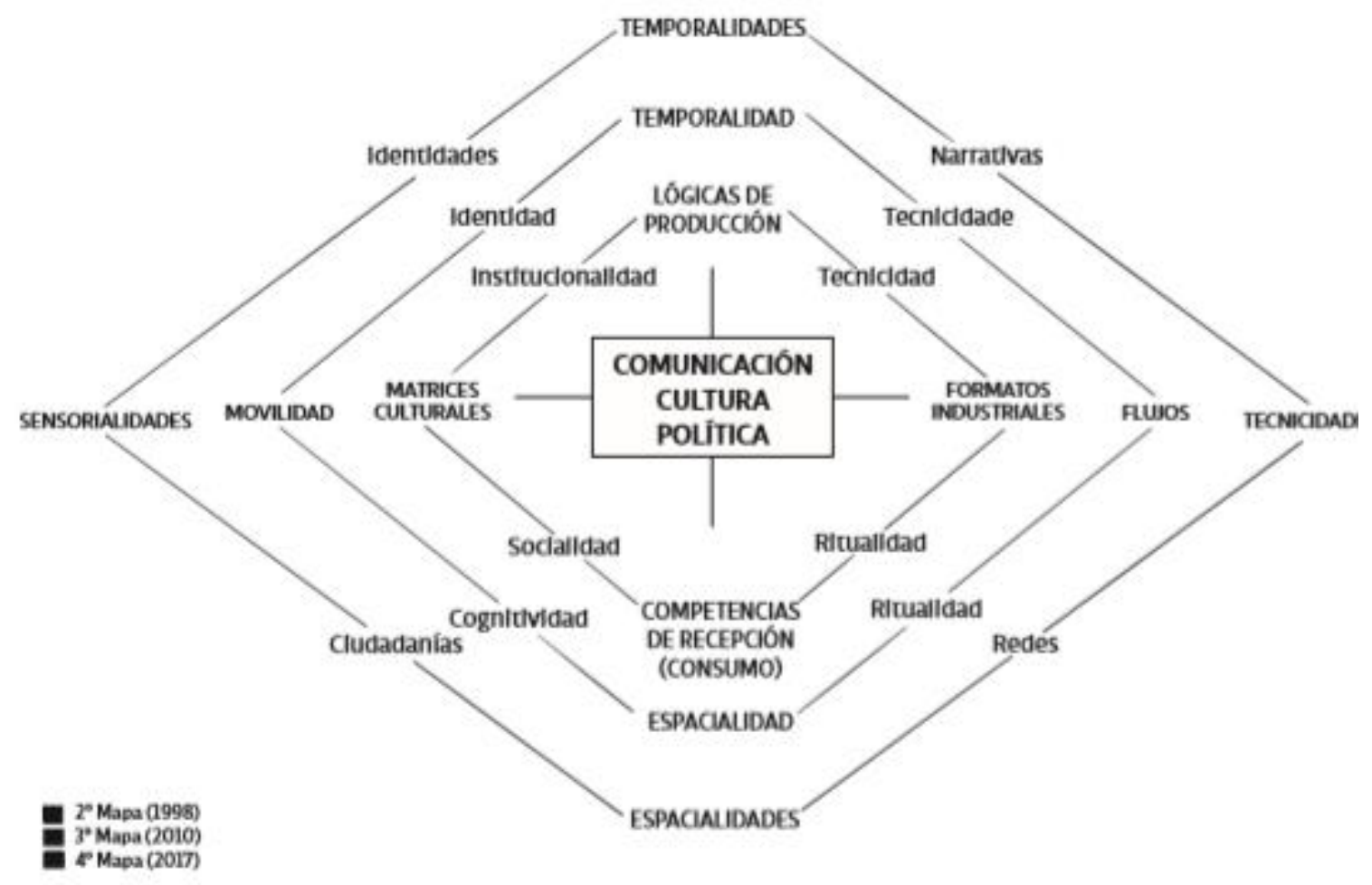

Fonte: Silva e Baseio (2019)

É com base nesse pensamento que desenvolvemos esta tese, pois mobilizamos os mapas de Martín-Barbero para dar conta de investigar a recepção da telenovela no novo cenário comunicacional em que estamos vivendo. Contexto de realidade mutável, complexo em meio ao apelo das redes sociais digitais e a novas possibilidades de empoderamento do receptor. 


\section{Capítulo 3: A era transmídia e a convergência midiática na ficção televisiva}

Neste terceiro capítulo da tese, discorremos sobre os avanços tecnológicos da atualidade e da demanda impositiva que causam nos meios de comunicação, tanto no que diz respeito às suas estruturas produtivas do fazer comunicacional quanto no modo de recepção e consumo. Desta maneira, apontamos algumas questões relevantes para evolução desse cenário atual contemporâneo, seus desdobramentos e as implicações desse novo ecossistema comunicacional. Discutimos pontos importantes sobre a cultura da convergência para entender como se formou esse novo paradigma. Após, tratamos das questões transmídia já consolidada nessa nova forma organizacional dos meios e da sociedade. Por último, adentramos especificamente na recepção transmidiática, já que este é um dos pontos empíricos de análise deste trabalho, portanto entendemos que o estado da arte, aliado a conceitos-chave sobre o assunto, são fundamentais para iluminar nossa pesquisa.

\subsection{A Cultura da Convergência}

Já é consolidada a noção de que o avanço das tecnologias, de alguma forma, impõe às estruturas produtivas dos meios de comunicação novos formatos e desafios para o fazer comunicacional. Como foi o caso da imprensa, do rádio e da televisão, que, a partir da sua concepção e, ao longo da história, trouxe avanços e rumores sobre o futuro, bem como a expansão das potencialidades de produção e circulação de conteúdos e mensagens.

Como identificou Castells (2004), vivemos em uma nova forma organizacional da sociedade, a Era da Informação, a qual tem, em sua base as ferramentas tecnológicas como os computadores e a internet, que exercem papel fundamental no desenvolvimento social. Conforme o mesmo autor, a estrutura social desta Era é formada por redes de produção, experiência e poder que constituem a cultura do virtual nos fluxos globais e que transcendem o espaço e o tempo (CASTELLS, 2003, p.476). Estamos em uma “[...] sociedade em rede multiconectada que traz, especialmente por meio do uso do computador e do celular, o acesso às novas mídias digitais que, na ficção televisiva, se materializam na TV digital, na TV pela internet, na convergência midiática [...]"' (LOPES, 2014, p. 13).

Assim, as novas mídias causaram e estão causando constantes transformações na 
sociedade (JENKINS, 2009; LÉVY, 1996), pois criam um "ecossistema midiático" envolvendo produtores e receptores, amplificam e facilitam encontros e visibilidades de comunidades virtuais, fortalecem relações, difundem opiniões. Enfim, criam, inevitavelmente, novas sociabilidades para os sujeitos que acessam as novas tecnologias, especialmente a internet. Esta não é um meio de comunicação, mas "assume tal status como uma plataforma multimodal que suporta diversos serviços de informação, armazenamento e comunicação, e que tem afetado tanto as lógicas dos ditos meios tradicionais como as práticas sociais dos sujeitos" (DEPEXE, 2015, p. 87). As sociabilidades contemporâneas, especialmente essas atreladas às práticas de consumo cultural das novas tecnologias comunicacionais, "só podem ser pensadas com base em uma dada mediação midiática" (SILVA; ANDRADE, 2006, p.142). Ou seja, a vida em sociedade nos dias atuais é atravessada pelo consumo das mídias, causando, assim, uma forma de sociabilidade que podemos chamar de midiática, sendo essas hibridas (DEPEXE, 2015) conforme o modo com que nos apropriamos e usamos os artefatos culturais que fazem parte da comunicação mediada tecnologicamente (jornais, televisores, películas, rádios, internet) em nosso cotidiano e como estas colaboram com a construção das relações sociais e estabelecem espaços sociais e temporais. Há, então, uma multiplicidade de formas com que a mídia e os sujeitos interagem, "construindo uma teia de sociabilidade complexa que conserva determinadas práticas sociais, revoluciona outras, ao mesmo tempo que atualiza alguns elementos particulares de incorporações anteriores" (SILVA; ANDRADE, 2006, p.143).

A convergência corresponde ao fluxo de conteúdos por meio de diversos suportes e plataformas midiáticas e à cooperação entre mercados e o comportamento dos receptores frente aos produtos midiáticos e as suas interações sociais. Conforme Jenkins (2009, p. 377), a cultura da convergência engloba as "mudanças tecnológicas, industriais, culturais e sociais no modo como as mídias circulam em nossa cultura". O autor classifica como cultura da convergência o momento atual que vivenciamos, pois as novas e as velhas mídias colidem, os medias corporativos e alternativos se entrecruzam, os poderes do produtor e do consumidor interagem de maneiras imprevisíveis e com diferentes interesses (JENKINS, 2009). Na mesma linha de pensamento, McQuail (2003, p. 120) afirma que "a consequência potencial mais 
amplamente notada para a instituição dos media é a convergência entre todas as formas existentes de media em termos da sua organização, distribuição, recepção e regulação".

Porém, a convergência midiática extrapola as questões técnicas, vai além do que apenas uma mudança tecnológica:

A convergência altera a relação entre tecnologias existentes, indústrias, mercados, gêneros e públicos. A convergência altera a lógica pela qual a indústria midiática opera e pela qual os consumidores processam a notícia e o entretenimento. Lembrem-se disto: a convergência refere-se a um processo, não a um ponto final. Não haverá uma caixa preta que controlará o fluxo midiático para dentro de nossas casas (JENKINS, 2009, p. 44).

Então, a convergência representa também uma mudança cultural, já que os sujeitos são constantemente incentivados a buscar novas informações, unir e interagir com conteúdos e mensagens midiáticas dispersos. É por meio dos computadores e das redes que as mais diversas pessoas podem entrar em contato umas com as outras, e mais do que se construir em torno da identidade de sentido, o novo universal é provado por imersão, um verdadeiro movimento social (LÉVY, 1997).

\subsubsection{A convergência e a ficção televisiva}

A cultura da convergência pode ser observada, especialmente, no campo televisivo com a expansão das plataformas de distribuição das telenovelas ou das séries para outras telas, fazendo com que o fluxo do conteúdo em uma mídia diferente ocasione também uma mudança na relação do espectador com o produtor midiático:

Dentro do âmbito da ficção latino-americana, observou-se que o fenômeno intermedial (televisão- internet) começa a dar seus primeiros passos ao situar as telenovelas em plataformas tecnológicas que ameaçam em reconfigurar os processos de recepção e consumo da ficção, pois ao estarem na rede, as telenovelas podem ser vistas a qualquer hora e de diversos lugares, alterando também seus usos e apropriações (OROZCO GÓMEZ, 2011, p.395, tradução nossa) $)^{32}$.

\footnotetext{
32 No original: "Dentro del ámbito de la ficción latinoamericana, se ha observado que el fenómeno intermedial (televisión-internet) comienza a dar sus primeros pasos al situar a las telenovelas en plataformas tecnológicas que amenazan con reconfigurar los procesos de recepción y consumo de la
} 
Assim, é possível perceber o notável impacto das tecnologias da informação à comunicação na adoção de novas estratégias de produção e distribuição de conteúdos convergentes, "pois atualmente quase todos os programas de ficção televisiva experimentam o online, produzindo variados tipos de brand extensions, atraindo os leitores para estes paratextos infinitos (LACALLE, 2010, p. 98)".

A cultura da convergência não transformou e transforma somente a produção midiática, mas também a recepção de tais conteúdos, por meio do fluxo que a própria recepção põe em circulação na rede (FAUSTO NETO, 2009). A partir dessa perspectiva, a convergência "é tanto um processo corporativo, de cima para baixo, quanto um processo de consumidor, de baixo para cima" (JENKINS, 2009, p. 46). Na esfera corporativa, estão os "materiais e serviços produzidos comercialmente, circulando por circuitos regulados e previsíveis" (Ibdem, p. 45) e, no outro âmbito, estão os "consumidores estão aprendendo a utilizar as diferentes tecnologias para ter um controle mais completo sobre o fluxo da mídia e para interagir com outros consumidores" (Ibdem, p.46). E ambas as esferas (corporativa e do consumo) coexistem, por vezes se fortalecendo mutualmente e por outras gerando "repulsa e conflito por um desajuste entre a estratégia e o controle do mercado frente ao comportamento migratório e contestador dos consumidores" (DEPEXE, 2015, p. 89).

Portanto, dois aspectos podem ser apontados como favorecedores dessa expansão de conteúdos que extrapolam a televisão e são as possibilidades de convergência de mídia e a cultura participativa (FREIRE, 2015, p. 63). A participação ativa dos consumidores como uma cultura participativa opõe-se à já superada noção de espectador passivo, pois, "Em vez de falar sobre produtores e consumidores de mídia como ocupantes de papéis separados, podemos agora considerá-los como participantes interagindo de acordo com um novo conjunto de regras, que nenhum de nós entende por completo." (JENKINS, 2009, p. 30). Esta participação é justificada pelo fato de que existe uma crescente alfabetização digital dos usuários, principalmente dos jovens, que possibilita a criação de diferentes comunidades de consumidores (LÉVY, 1994;

ficción, pues al estar montadas en la red, las telenovelas pueden ser vistas a cualquier hora y desde diversos lugares, alterándose también sus usos y apropiaciones”. 
VILCHES, 2003; JENKINS, 2009). Lévy (1994) assegura que os mundos virtuais como instrumentos de autodefinição e autoconhecimento de grupos humanos e construídos em internos coletivos autônomos são denominados de "inteligência coletiva"(Ibdem, p. 129). Seguindo o autor, Jenkins (2009) acrescenta que esta inteligência refere-se à habilidade que as comunidades virtuais têm de formarem conhecimentos combinados e os compartilharem entre seus membros, já que "o que não podemos saber ou fazer sozinhos, agora podemos fazer coletivamente" (Ibdem, p. 56).

Segundo Jenkins (2006, 2009) e Hartley (2005), a convergência de conteúdos ficcionais acontece tanto a partir de iniciativas de indústrias criativas ${ }^{33}$ que visam acelerar os fluxos de conteúdos de mídia e ampliar suas receitas, quanto por meio de atividades dos fãs que usam as tecnologias para interagir, usufruir e compartilhar conteúdos. Porém é preciso destacar que estes consumidores usam e se apropriam de maneiras diferentes dos conteúdos de mídia, dependendo de suas habilidades e engajamento. O público, então, é agora detentor de poder propiciado pelas novas tecnologias e ocupa um espaço no cruzamento entre os novos e os tradicionais meios de comunicação, exigindo, assim, o direito de participar ativa e intimamente da cultura. E os produtores que não derem conta dessa nova cultura participativa terão que enfrentar um declínio de sua clientela e, por consequência, uma diminuição de seus lucros (JENKINS, 2009). Por isso, cada vez mais os veículos de comunicação investem na criação de conteúdos para diferentes mídias, como é o caso da televisão, com as ficções, como conclui Evans (2008, p. 25): "Com o desenvolvimento das novas tecnologias midiáticas, ficções televisivas passaram a ser produzidas para envolver múltiplas formas audiovisuais de entretenimento, oferecendo diferentes maneiras de interatividade[...]”.

A convergência e sua influência com relação aos receptores é um fenômeno simultâneo mediado pelos dispositivos tecnológicos de mídia de massa e dispositivos comunicacionais interpessoais no trânsito de seus conteúdos veiculados (CARR et. al., 2008). Tal fenômeno pode ser observado quando o receptor assiste à telenovela $\mathrm{e}$,

\footnotetext{
33 São os grandes conglomerados de mídia, dispostos em sistema de atividades "organizadas e coordenadas sob fluxos de valor através da empresa que cria produtos e do consumo como fruto de um bem social pelas trocas, principalmente de conteúdos em sites de redes sociais" (POTTS et. al. ,2008, p. 170). "Isto inclui publicidade, arquitetura, mercado de arte e antiguidades, artesanato, design, mercado fashion, cinema e vídeo, software interativo de entretenimento, música, artes cênicas, edição, software e jogos de computador, televisão e rádio (DEUZE, 2007, p. 248)”.
} 
ao mesmo tempo, posta comentários sobre a trama em alguma rede social, como Twitter, por exemplo. Diversos autores descrevem essa prática simultânea da audiência de customização de conteúdo como individuated mass media (CARR et. al., 2008); mass-personal communication (CASTELLS, 2009); personal broadcasting (LASICA, 2005).

Desta interação receptor-ficção televisiva surge o termo segunda tela, que é justamente a convergência entre TV e as redes sociais, caracterizada pela oferta de uma experiência personalizada para a audiência. Esta segunda tela funciona "como um espaço comunicativo e de recepção de conteúdos relacionado a uma outra tela geralmente a da televisão[...]” (JUNIOR, 2014, p. 2). A TV continua sendo a tela principal de uso, consumo e apropriação por partes dos receptores, pois ainda é o principal divulgador de conteúdos de mídia expandindo sua grade de programação (JENKINS, FORD e GREEN, 2013). O que acontece é que é acrescentada a ela, essa outra tela, que pode ser a do computador ou a do telefone celular. Alguns autores já identificam o celular como "terceira tela" (DELLER, 2011; MARTIN, 2011; DOUGHTY, ROWLAND e LAWSON, 2012). Isto é possibilitado pelo crescimento do acesso à banda larga e smartphones no mundo, e o Brasil segue essa crescente tendência. Segundo a Kantar IBOPE Media ${ }^{34}$, desde 2013, há um crescimento veloz e cada vez mais consistente do alcance de banda larga no país que hoje está disponível para $82,66 \%$ dos brasileiros. O mesmo crescimento acontece com a posse de smartphones no país, pois até 2017, 70\% dos brasileiros já possuiam o dispositivo. Segue a figura:

\footnotetext{
34 Disponível em: https://br.kantar.com/m\%C3\%ADdia/\%C3\%A1udio,-texto,-tv-ev\%C3\%ADdeo/2017/ultimos-10-anos-tv-transformacao-quem-te-viu-quem-tv/ Acesso em junho de 2018.
} 


\section{Figura 7: Posse de smartphone no Brasil ao longo dos anos}

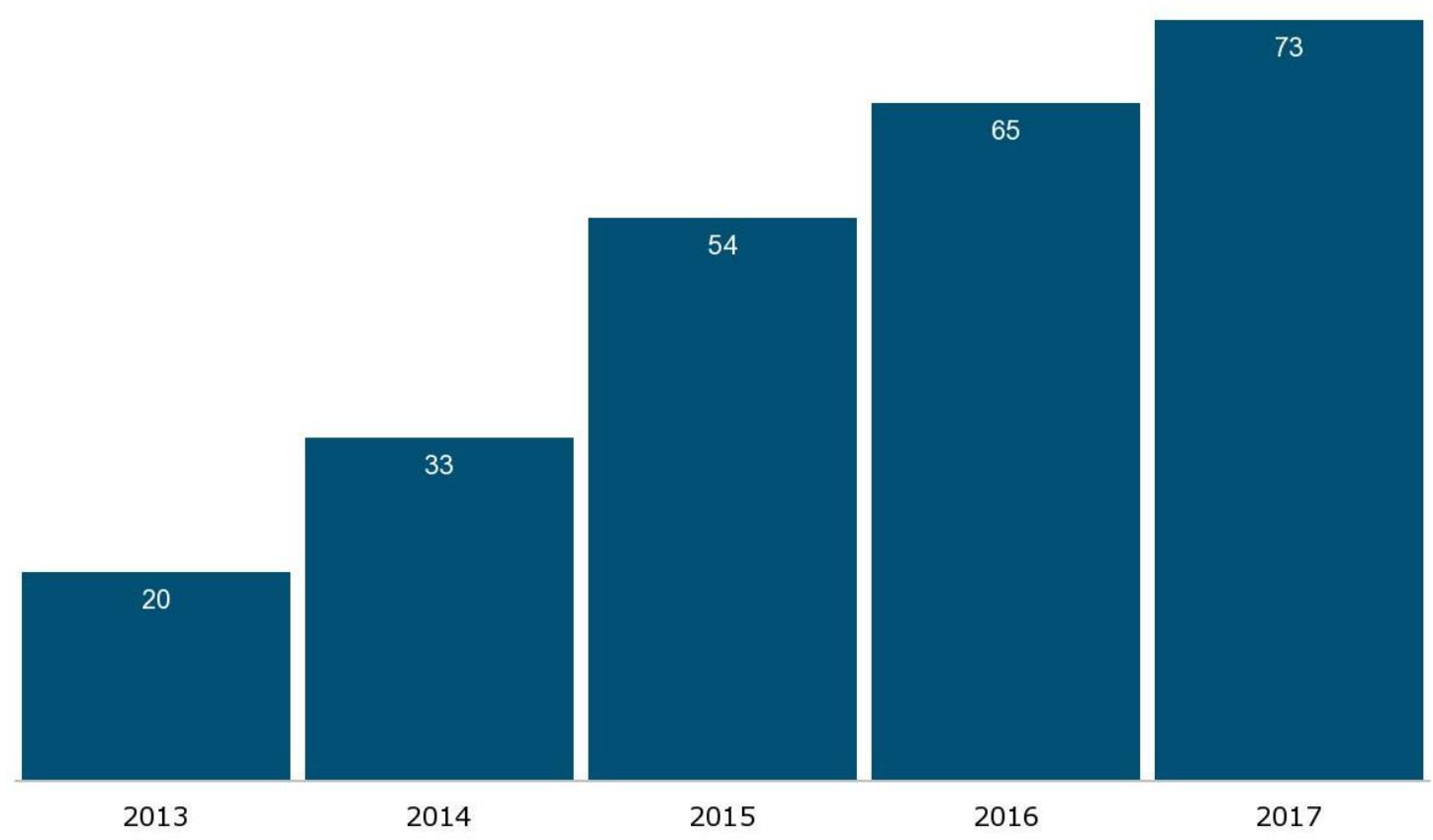

Fonte: Kantar Ibope Media

Conforme uma pesquisa da Fundação Getúlio Vargas de São Paulo ${ }^{35}$, em 2019, o Brasil já tinha dois dispositivos móveis (smartphones, computadores, notebooks e tablets) por habitante, sendo que o número de smartphones destaca-se, são 235 milhões de telefones celulares ativos no país.

As formas de acesso à internet também estão mudando no país, em crescente ascensão. Hoje o acesso via telefone celular é maior do que por meio de computador, como também afirma a Kantar IBOPE Media na mesma pesquisa acima e o IBGE ${ }^{36}$. Hoje, 94,6\% dos brasileiros acessam a web pelo telefone celular. O gráfico abaixo ilustra tal crescimento nos últimos anos:

\footnotetext{
35 Disponível em: https://eaesp.fgv.br/sites/eaesp.fgv.br/files/pesti2019fgvciappt_2019.pdf Acesso em janeiro de 2020.

36 Disponível em: https://agenciadenoticias.ibge.gov.br/agencia-sala-de-imprensa/2013-agencia-denoticias/releases/20073-pnad-continua-tic-2016-94-2-das-pes soas-que-utilizaram-a-internet-o-fizerampara-trocar-mensagens Acesso janeiro de 2020.
} 
Figura 8: Formas de acesso à internet no Brasil

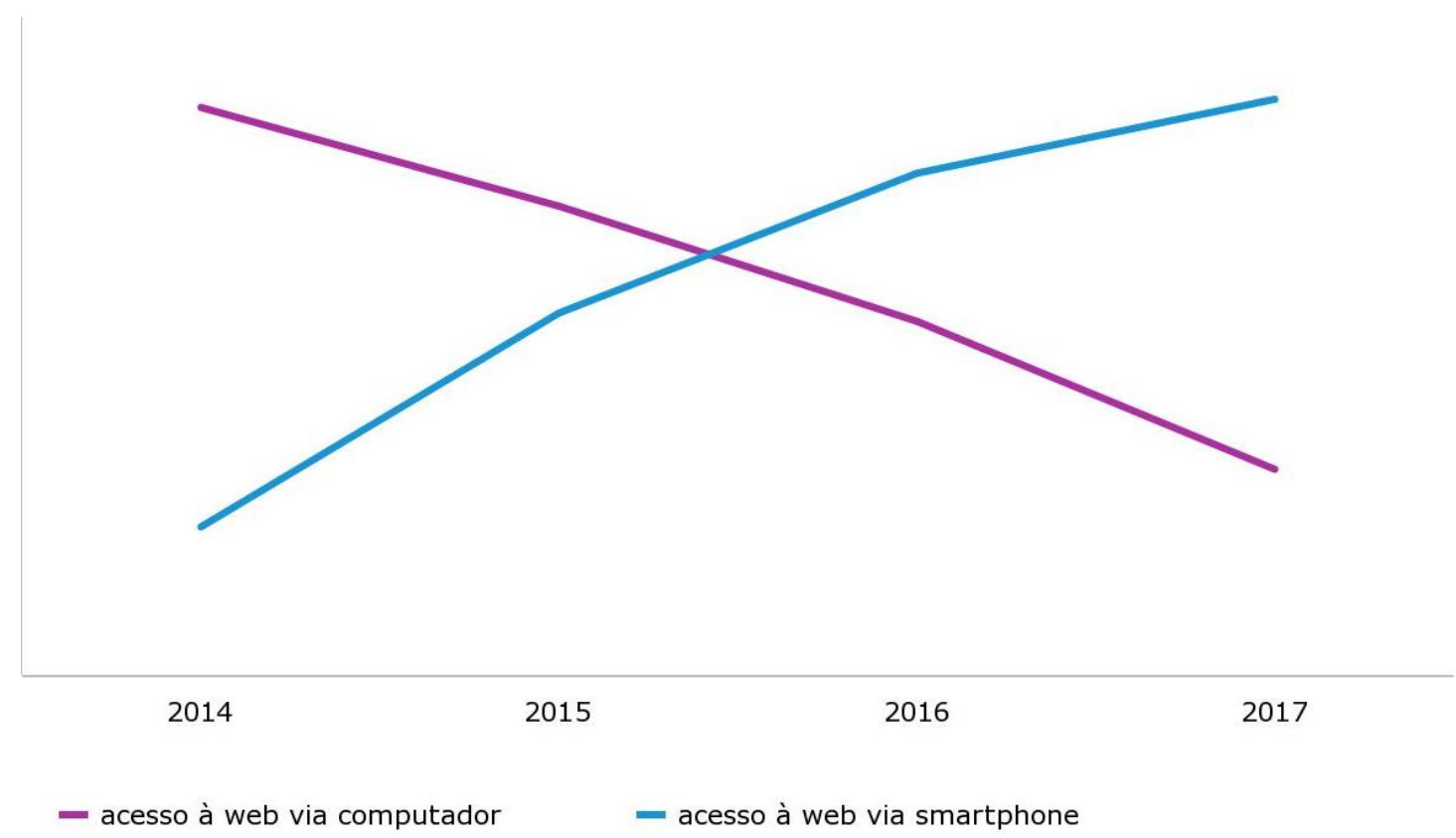

Fonte: Kantar Ibope Media

Outra pesquisa sobre os hábitos de consumo de vídeo, TV e banda larga realizada em 13 países, incluindo o Brasil, desenvolvida pelo ConsumerLab ${ }^{37}$, da empresa Ericsson, revela que a quantidade de pessoas que assiste a vídeos pelo telefone celular aumenta cada vez mais. Atualmente, quase $70 \%$ dos usuários entrevistados (cerca de 20 mil) assistem regularmente a conteúdos de vídeo por meio do smartphone. A mesma pesquisa aponta que, até o final de 2020, metade dos acessos a filmes, séries e programas de TV será feito via dispositivos móveis, como smartphones, tablets e notebooks.

Mesmo com esses novos comportamentos de consumo não linear por parte da audiência, é preciso ressaltar que o consumo médio de TV se manteve em contínuo crescimento no Brasil, na última década, como apontam o OBITEL (Observatório Ibero-americano de Ficção Televisiva) e a Kantar IBOPE Media.

\footnotetext{
37 Disponível em: https://www.ericsson.com/en/trends-and-insights/consumerlab/consumerinsights/reports/10-hot-consumer-trends-2017 Acesso em maio de 2018.
} 
Figura 9: Consumo médio de televisão entre os telespectadores brasileiros

\section{Consumo médio individual de TV entre telespectadores}

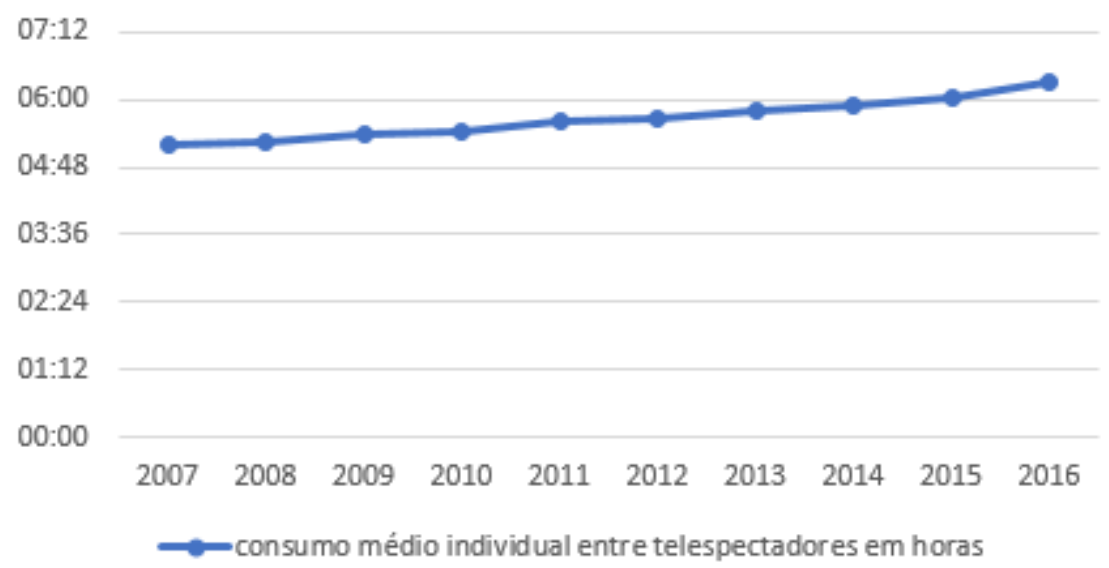

Fonte: Kantar IBOPE Media

O uso e as apropriações dessas outras múltiplas telas exige do receptor "a necessidade de uma capacitação afetiva e social para coordenar diversas conversas" (ALMEIDA, 2014, p. 7) ao mesmo tempo em que assiste ao conteúdo nesses variados espaços e os publica, transitando não só o olhar, mas o corpo entre diferentes teclados e telas. De acordo com Jenkins, Ford e Green (2014), os temas de romance, amizade e comunidade são comuns nas criações de fãs na internet, assim existe uma espécie de "fantasia compartilhada" que assume o tom da estratégia de produção do conteúdo, configurando, assim:
A experiência social na televisão multiplataforma inclui formas novas de relação entre os telespectadores por meio das diferentes interações realizadas nas redes sociais. Os dispositivos digitais permitem, por exemplo, que ao assistir a um conteúdo interessante os telespectadores acessem e enviem o material por e-mail ou WhatsApp a um amigo ou o disponibilize em seu perfil no Facebook [...] (ALMEIDA, 2014, p. 7).

$\mathrm{Na}$ web, a temporalidade da exibição dos conteúdos fica a critério do receptor, pois é ele que define se, quando, onde e como irá acessar um determinado conteúdo, não precisando ficar à mercê da grade de programação televisiva ou radiofônica, por exemplo. O que é consumido agora fica a critério do espectador. Esta flexibilidade e mobilidade de assistência é possibilitada principalmente pelas plataformas streaming - 
como Globo Play (Globo), TV SBT (SBT), Now (NET), Vivo Play (Vivo) e Record TV no Youtube - e pelos vídeos on demand (VoD). Tendências estas cada vez mais consolidadas (OBITEL, 2017) não só no Brasil, mas também mundialmente. Essa capacidade "de romper com o tempo pré-determinado pela indústria televisiva ameaça diretamente uma de suas características essenciais: o que Raymond Williams (2016) nomeou de fluxo" (ALMEIDA, 2018, p. 1306). O autor britânico utiliza o termo fluxo para analisar a televisão como tecnologia e forma cultural, em oposição ao conceito de distribuição, que, para ele, é limitado e estático. O fluxo é a chave fundamental para entender a programação televisiva, descrevendo sua natureza estável por meio do próprio aparelho e da forma com que a narrativa e as constantes interrupções comerciais são combinadas.

Então, ainda conforme Williams (2016), a TV não seria apenas uma disposição de diversas unidades audiovisuais individuais sucedidas, e sim um fluxo constante e planejado: uma sequência que se transforma por meio da inclusão de outro tipo de sequência, e assim por diante, então é o conjunto de tais sequências que constitui o verdadeiro broadcasting. E são os termos "convergência midiática" (JENKINS, 2008) ou "luta intermídias" (JOST, 2011) que objetivam dar conta de um cenário contemporâneo de coexistência e disputa entre as diferentes mídias que provocam rupturas no fluxo dos meios massivos. Porém, entendemos que, apesar desse novo cenário tecnológico romper com o fluxo televisivo tradicional, há a criação de um novo fluxo onde circulam as narrativas dos diferentes meios de comunicação, os conteúdos gerados por eles e a interação dos receptores bem como também os conteúdos gerados por usuários.

Assim, a cultura da convergência, a experiência e as mudanças que esta proporciona têm relação direta com outro conceito fundamental para essa nova Era da Informação que estamos vivenciando, o conceito de transmídia.

\subsection{A transmídia e a ficção televisiva}

A expansão em múltiplas plataformas dos textos midiáticos possibilitados, conforme citamos acima, pela convergência, demonstra o que Jenkins (2006, p. 98) afirmou ser "transmídia", pois disponibiliza "novas formas de experimentação, ao

mesmo tempo em que sustenta a lealdade de fãs aos conteúdos midiáticos". Para o 
autor, a audiência cada vez mais conectada socialmente interage com as indústrias criativas e entre si através das "narrativas transmídia" ou "transmedia storelling", (JENKINS, 2003). Assim, uma narrativa passa a ser expandida para outras mídias e produtos e seu universo é explorado em outras plataformas, como jogos, brinquedos ou produtos de uma rede social. É considerada uma história transmidiática aquela que se desdobra por meio de múltiplas plataformas de mídia, mas que cada qual possui um novo texto, fazendo uma colaboração distinta e valiosa para o todo. Dessa maneira:

na forma ideal de narrativa transmidiática, cada meio faz o que faz de melhor a fim de que uma história possa ser introduzida num filme, ser expandida pela televisão, em romances e quadrinhos, seu universo possa ser explorado em games ou experimentado como atração de um parque de diversões (JENKINS, 2008, p. 135).

Conceito semelhante foi utilizado por Kinder (1991) para descrever os "sistemas comerciais transmídia" na expansão de conteúdos relativos a personagens, pois, desde a década de 1990 as indústrias criativas já apontavam para o interesse de diversificar e incentivar o consumo de seus produtos ficcionais. Mittel (2015) também pontua que o conceito de narrativa transmídia não remete a algo tão novo, já que, para o autor, a estratégia de expandir narrativas para outros meios é tão antiga quanto as próprias mídias em si. O pesquisador cita Frankenstein e Sherlock Holmes, cujos universos extrapolam uma mídia única. Evans (2011) afirma que a expressão "narrativa transmídia" é imprecisa e exige um maior refinamento do conceito por parte dos teóricos do campo. Ela recorre a Pearson (2009), outra autora que questiona os limites do conceito de transmídia para justificar sua afirmação. Tal pesquisadora sugere que as histórias bíblicas também poderiam ser consideradas como multiplataformas e transmidiáticas já que estão presentes em pinturas, livros e filmes, por exemplo.

Com essas afirmações, é possível observar que o termo já se tornou amplo, abrindo brechas para se considerar que toda manifestação de uma mesma narrativa em dispositivos midiáticos diversos já poderia ser classificada como transmídia (ALMEIDA, 2018, p. 1507-1513). O próprio Jenkins, precursor responsável pela popularização do conceito, escreveu que o termo pode variar, ora fazendo referência a um esforço da produção em disponibilizar de forma articulada os conteúdos narrativos considerados canônicos como o filme Matrix, ora incluindo também a produção e a performance de consumidores realizada no ambiente da cultura de fãs, como as fan 
fictions (narrativas ficcionais escritas por fãs, apropriando-se do texto de referência), as discussões em fóruns, blogs, e a atuação engajada em redes sociais.

A transmidiação é definida como uma ação estratégica de comunicação que necessariamente acontece a partir de um produtor, usualmente filiado à indústria midiática, que será responsável pela produção e disponibilização dos conteúdos transmidiáticos. Há exceções, ainda que com menos frequência, em que o produtor pode ser um agente independente de grandes conglomerados. E, apesar da integração entre meios ser a base dos fenômenos transmídias, há uma regência de uma determinada mídia na articulação que se promove entre as diferentes mídias. É nessa mídia caracterizada como regente que se desenvolve o texto de referência, ou seja, um conteúdo narrativo principal a partir do qual se darão os desdobramentos e articulações (FECHINE et al., 2013, p. 28-29).

A crescente disponibilização de conteúdos não só atende demandas de empresas de televisão, como também proporciona a imersão das audiências em universos ficcionais complexos e interativos. A criação de um ambiente de histórias para multiplataformas dissolve as barreiras convencionais entre arte, comunicação e o entretenimento, pois requer parâmetros de análise que contemplem obras ramificadas por extensões narrativas e que, por isso, não podem ser considerados como "obras únicas", tais como: filmes, jogos, séries de TV e HQs, entre outras. (MASSAROLO; MESQUITA, 2014, p. 2).

Mas foi a digitalização da contemporaneidade que permitiu ao conteúdo das mais variadas mídias circular com maior facilidade entre um formato e outro. Portanto, há a necessidade também de se problematizar as ações transmídia sob os aspectos narrativos:

$\mathrm{Na}$ noção de uma estratégia transmídia, a proliferação e simultaneidade de subtramas cumprem os mesmos objetivos. Só que, agora, as extensões da telenovela ocorrem em direção a outros meios - Internet, de modo mais frequente -, assumindo, geralmente, a forma de "suplementos" ou de conteúdos adicionais exclusivos [...] Essas extensões, geralmente, não possuem uma implicação direta na trama principal, mas possuem uma função catalisadora na narrativa: caracterizam e detalham o mundo imaginário criado pelo autor, constroem a "atmosfera" e o ambiente ficcional no qual o espectador se projeta. (FECHINE; FIGUEIRÔA, 2011, p. 36).

Conforme Scolari (2009), a narrativa transmídia é uma estrutura que se expande 
tanto em termos de linguagens (verbais, icônicas, textuais) quanto em termos de mídias (televisão, rádio, celular, internet, jogos, quadrinhos). E tem como característica a complementação das histórias quando são passadas de uma mídia para outras e não apenas a repetição de uma mídia para a outra. Assim, as histórias devem ter sentido também se analisadas isoladamente. Jenkins (2009) define como narrativas transmídia o relato das histórias distribuído em diversas plataformas midiáticas onde cada texto contribui de maneira diferente para o todo. A narrativa é concebida de forma sinergicamente ampla, tendo a capacidade de extrapolar os limites de um único meio de comunicação e migrar para outros:

Uma história transmídia representa a integração de experiências de entretenimento em uma variedade de plataformas de mídia diferentes. Uma história como Heroes ou Lost pode se espalhar da televisão para quadrinhos, web, computador ou jogos alternativos de realidade, brinquedos e outras mercadorias, e assim por diante, conquistando novos consumidores e permitindo que os fãs mais dedicados se aprofundem mais. Os fãs, por sua vez, podem traduzir seus interesses na franquia em concordâncias e entradas da Wikipedia, ficção de fãs, vídeos, filmes de fãs, cosplay, mods de jogos e uma série de outras práticas participativas que ampliam ainda mais o mundo da história em novas direções. A expansão comercial e popular dos universos narrativos contribui para um novo modo de contar histórias, baseado em uma expansão enciclopédica de informações reunidas de maneira diferente por cada consumidor individual e processadas coletivamente por redes sociais e comunidades de conhecimento on-line (JENKINS, 2010, p. 448 , tradução nossa) ${ }^{38}$.

O conceito transmedia storytelling é usualmente empregado para designar a possibilidade de acesso do mesmo conteúdo em múltiplas telas, mas Lopes e Mungioli (2011, p. 253) afirmam que o conceito propõe um '[...] desdobramento da história principal que ganha elementos diferentes (personagens, ambientes, conflitos) conforme as características e qualidades que cada meio oferece para desenvolver a narrativa. Existem três características para o desenvolvimento eletrônico das

\footnotetext{
${ }^{38}$ No original: " A transmedia story represents the integration of entertainment experiences across a range of different media platforms. A story like Heroes or Lost might spread from television into comics, the web, computer or alternate reality games, toys and other commodities, and so forth, picking up new consumers as it goes and allowing the most dedicated fans to drill deeper. The fans, in turn, may translate their interests in the franchise into concordances and wikipedia entries, fan fiction, vids, fan films, cosplay, game mods, and a range of other participatory practices that further extend the story world in new directions. Both the commercial and grassroots expansion of narrative universes contribute to a new mode of storytelling, one which is based on an encyclopedic expanse of information which gets put together differently by each individual consumer as well as processed collectively by social networks and online knowledge communities".
} 
narrativas transmídias: a imersão, o sentido de agenciamento e a transformação (MURRAY, 1997). A autora acredita que o computador satisfaz as fantasias ficcionais dos usuários de uma forma mais incisiva através da imersão e transporta esses usuários para lugares imaginários por meio de simulação:

A experiência de ser transportado para um local elaboradamente simulado é prazerosa em si mesma, independentemente do conteúdo da fantasia. Nós nos referimos a essa experiência como imersão. Imersão é um termo metafórico derivado da experiência física de estar submerso na água. Buscamos o mesmo sentimento de uma experiência psicologicamente imersiva que fazemos de um mergulho no oceano ou piscina: a sensação de estar cercado por uma realidade completamente diferente, tão diferente quanto a água do ar, que toma toda a nossa atenção, todo o nosso aparato perceptivo (MURRAY, 1997, p. 98, tradução nossa) ${ }^{39}$.

O agenciamento, conforme a mesma autora, é o poder de decisão sobre os conteúdos e o domínio superior ao da participação e da interatividade, observado nos ambientes de intensa interatividade como videogames, pois estes podem reformular a estrutura das narrativas. Assim, a transformação de conteúdo é uma consequência do processo.

A imersão diz respeito ao envolvimento dos usuários com o drama e está intimamente ligada ao sucesso ou fracasso dos projetos transmídia. Evans (2011) analisou que os níveis de engajamento com o drama variam de acordo com as plataformas de distribuição das narrativas. Em sua pesquisa de 2011, os jovens entrevistados apontaram os videogames como uma experiência potencialmente catártica, onde conseguem permanecer submersos por semanas (EVANS, 2011, p. 176-177). Mas, apesar da facilidade de transporte, a assistência nos telefones celulares é uma experiência menos envolvente devido ao tamanho das telas e ao contexto de visualização. Mesmo sendo importante para o sucesso das narrativas transmídia de forma geral, a imersão tem sido vista como um dos principais elementos responsáveis pela alienação dos usuários. Pois, segundo os teóricos mais

\footnotetext{
${ }^{39}$ No original: "The experience of being transported to an elaborately simulated place is pleasurable in itself, regardless of the fantasy content. We refer to this experience as immersion. Immersion is a metaphorical term derived from the physical experience of being submerged in water. We seek the same feeling from a psychologically immersive experience that we do from a plunge in the ocean or swimming pool: the sensation of being surrounded by a completely other reality, as different as water is from air, that takes over all of our attention, our whole perceptual apparatus".
} 
críticos, quanto maior a proximidade com a ficção por parte dos usuários, menor o interesse pela realidade. Por exemplo, Toffoletti (2008) argumenta que o supersistema (KINDER, 1991) causado pelo universo transmídia resulta em produtos alienantes característicos da sociedade do espetáculo (DEBORD, 1972). De acordo com esta perspectiva, o potencial imersivo das narrativas transmídia pode ocasionar problemas, principalmente com relação aos jovens pois eles tendem a abdicarem de outras atividades importantes do dia a dia pelos momentos de entretenimento e lazer frente aos computadores e telefones celulares. Em contraponto, Evans (2011) afirma que as ficções americanas de qualidade, como por exemplo Spooks (BBC, desde 2002) e 24 (Fox, desde 2001), disponibilizam uma experiência imersiva em que os receptores sentem-se envolvidos com o mundo ficcional de maneira positiva.

Scolari (2013, p. 26) afirma que há um crescimento de uma galáxia semântica em torno do conceito de transmedia storytelling, já que há

um planeta dentro de uma imensa galáxia conceitual, formada por termos que procuram nomear uma só experiência: a prática de produção de sentido e interpretação, baseada em histórias que se expressam através da combinação de linguagens, meios e plataformas.

Para Evans (2011), é indispensável que se aponte as diferenças demarcadas entre as narrativas transmídia e as produções tradicionais de ficção, pois, para a autora, a materialização das narrativas sempre ocorreu em plataformas diferentes.

Gray (2010, p. 23) classifica os elementos de expansão do universo ficcional a partir do conceito de paratextos de Genette (2011, p. 1, tradução nossa ${ }^{40}$ ), em que "[...] o paratexto é o que permite que um texto se torne um livro e seja oferecido como tal a seus leitores e, em geral, ao público". Portanto, o paratexto é um prolongamento da obra original que depende das formas de mediação, afinal, antes de serem publicados, os textos não possuem elementos paratextuais como título, subtítulos, intertítulos, prefácios, preâmbulos, apresentação e outras informações adicionais que influenciam o consumo dos leitores, se utilizarmos o exemplo de um livro. Desta maneira, se as narrativas podem concretizar-se em diversos suportes expressivos - verbais, icônicos ou verbo-icônicos (REIS e LOPES 2007), por assim

\footnotetext{
${ }^{40}$ No original: "the paratext is what enables a text to become a book and to be offered as such to its readers and, more generally, to the public".
} 
dizer, a narrativa transmídia não seria algo inteiramente novo, apesar das suas qualidades experimentais e inovadoras (JENKINS, 2009) ocasionadas pelas novas tecnologias.

Em se tratando de combinação narrativa, a forma ideal de transmidiação deve ser pressuposta pela alteração dinâmica de conteúdo e sua interligação com os meios onde cada diferente plataforma oferece distintas oportunidades de fruição e fluxo da história (JENKINS, 2009). Ainda, conforme o autor, o universo narrativo é, então, explorado conforme as potencialidades de cada meio, evitando a sobreposição por redundância e oferecendo novos níveis de revelação e experiência, pois, na era em que tudo é fluído e rápido, a repetição pode aborrecer os usuários. A transmidiação, assim,

“[...] enfatiza os processos de criação e veiculação dos produtos midiáticos, sejam eles de informação ou de entretenimento, regidos não pelo princípio da adaptação ou da tradução intersemiótica (JAKOBSON, 2003), mas, sobretudo, pelo princípio da convergência." (LOPES e MUNGIOLI, 2011, p. 250).

Para Müller (2009), os sites de compartilhamento de vídeos como o YouTube são exemplos de como as indústrias midiáticas investem nas novas tecnologias digitais para redefinir a relação entre as esferas da produção e do consumo.

Assim:

a reconfiguração das relações entre produtores e consumidores adquire protagonismo na discussão sobre os ambientes transmediados de ficção, na medida em que a diluição de fronteiras entre texto e leitor configura-se como elemento fundamental da transmediação (CASTILHO, 2014, p. 104).

O processo de transmidiação faz com que os olhares dos pesquisadores se voltem para as investigações sobre a recepção nesse novo ambiente, a então recepção transmídia. 


\subsection{A recepção transmídia de telenovela}

O processo comunicativo deve ser considerado como um todo, já que "a recepção não é algo aberto e perfeitamente transparente, que acontece na outra ponta da cadeia de comunicação" (HALL, 2006, p. 334). Esse processo comunicativo é composto pela produção, circulação, distribuição, consumo, recepção e reprodução, e nos ateremos neste tópico à reflexão sobre a recepção da telenovela no contexto das novas mídias. Seguimos a concepção de que “[..] o processo de recepção é, ao mesmo tempo, território compartilhado por produtores e consumidores, e cenário de luta pela interpretação mais legítima do sentido" (MARTÍN-BARBERO, 2002, p. 15).

Os estudos de recepção no país demonstram a complexa realidade brasileira, principalmente porque partem da ótica do cotidiano dos receptores em seus mais diversos contextos sociais e culturais. Isto porque atentam para os mais variados processos que envolvem os mais diversos espaços, como a cultura nacional, as culturas regionais e os mais diferentes nichos de receptores (mulheres, idosos, homens, crianças, jovens, educadores, etc.). $\mathrm{O}$ processo de recepção é estudado a partir da problematização do contexto social e cultural em que está inserido, e a comunicação não pode ser pensada separada das suas relações com a sociedade.

Devido às inúmeras demandas ocasionadas pelo atual ecossistema midiático, caracterizado por fluxos, velocidade e constantes mudanças, as ficções devem se adaptar e readequar também de forma constante. Por isso, um formato tão tradicional no país como a telenovela, para continuar sendo um produto midiático que possibilita um ritual compartilhado de assistência também passa por tais readaptações, principalmente para também se fazer presente nas múltiplas telas. Por meio do compartilhamento de gostos e opiniões, são construídas outras ritualidades no consumo das duas telas e se reforçam, assim, a cultura participativa e a inteligência coletiva, elementos essenciais à cultura da convergência (JENKINS, 2009).

Como já discutido acima, "a introdução da internet como mediação contribui para desestruturação dos limites entre texto e leitor, resultando em profundas alterações nos processos de produção e recepção de conteúdos de ficção" (BOOTH, 2010). O estudo da recepção desses conteúdos multiplataformas e de múltiplas telas proporcionados pelas novas tecnologias cunhou um novo campo de investigação na comunicação dentro dos estudos de novas mídias, que é a pesquisa de recepção 
transmídia. Ou seja, é a observação dos conteúdos e textos de mídia gerados e/ou postos em circulação pelas audiências, assim como a interatividade ou não com ações ou estratégias transmídia apresentadas pelos produtores.

Lopes et. al. (2009) identificaram uma das primeiras iniciativas em estratégias ou ações transmídia na telenovela brasileira em Caminho das Índias (Globo, 2009), ao investigar as perspectivas interativas propostas pelo site oficial da telenovela. Lopes at. al. (2009) utilizam as noções de Lévy ${ }^{41}$, Orozco Gómez e Primo para observar as três formas de interatividade a serem observadas na homepage. A interatividade passiva diz respeito à navegação na página, ou seja, ao consumo do conteúdo sem um feedback do receptor; a interatividade ativa corresponde às ações em que o usuário responde, de forma limitada, a um estímulo do emissor; e, a interatividade criativa é a que o receptor é estimulado e lhe é permitido produzir algo novo, como ocorre ao comentar uma publicação na página. Portanto, há proximidade conceitual entre a proposta de Lopes e a de Lévy, uma vez que ambas levam em conta as mensagens (ou conteúdo) e o espaço em que se desenvolvem as interações.

Jenkins (2009) diferencia interatividade e participação problematizando sobre a estrutura técnica, das relações sociais e culturais em jogo na constituição desses fenômenos. Segundo o autor, a interatividade é restrita tecnologicamente, com espaços de ação previamente determinados pelo produtor e, dependendo do grau de interatividade planejado, permite aos sujeitos maior ou menor autonomia de fazeres. Já a participação é caracterizada por ser mais ilimitada e regida por protocolos culturais e sociais e, portanto, torna mais livre as possibilidades de atuação. Porém, interatividade e participação muitas vezes se confundem, mas provocam relações de diferentes níveis com os conteúdos de mídia, porque "permitir aos consumidores interagir com as mídias sob circunstâncias controladas é uma coisa; permitir que participem na produção e distribuição de bens culturais - seguindo as próprias regras é totalmente outra" (JENKINS, 2009, p.190).

\footnotetext{
${ }^{41}$ Lévy (1999) aponta três diferentes níveis de interatividade que se definem a partir da relação com a mensagem: a) mensagem linear não alterável em tempo real (quando não há possibilidade de alterar o conteúdo emitido); b) interrupção e reorientação do fluxo informacional em tempo real (quando é possível a resposta ou trânsito de conteúdo entre emissor e receptor); c) implicação do participante na mensagem (quando o receptor tem controle sobre a mensagem e torna-se, também, emis sor).
} 
Os estudos de fãs contemplam as reflexões sobre essa diversificação e fragmentação das audiências (LOPES e MUNGIOLI et al.,2011) nesse fluxo de conteúdos que perpassam as diferentes mídias. O fã é aquele que participa de uma série de atividades que ultrapassam o ato privado de assistência da ficção (BIELBY, HARRINGTON e BIELBY, 1999) e "passa a se envolver emocionalmente com a trama e a criar laços profundos com a ficção [...]. Esse fã tenderá a explorar ao máximo aquilo que a produção oferece, conhecerá bem os personagens e o rumo de suas histórias (LOPES e MUNGIOLI et al., 2011, p.18).

Portanto existe diferença entre ser fã de ficção televisiva e ser espectador, a qual:

[...] pode ser apontada por meio do engajamento com as narrativas televisivas e, ao mesmo tempo, a produção de conteúdo. Os fãs correspondem à parte do público espectador que não apenas assiste a filmes ou programas de televisão, mas também produz conteúdos relativos à ficção ou assume uma postura crítica e desenvolve sua própria arte, incorporando partes das narrativas televisivas em vídeos, sites, além de seguir outros fãs no seu entusiasmo (Ibdem, p. 246).

Lopes e Mungioli et al. (2011) avançam nessa diferenciação entre o receptor transmídia, elaborando uma tipologia de fãs por meio da investigação da recepção transmidiática da telenovela Passione (Globo, 2011). Esta tipologia foi feita a partir de um levantamento sobre os tipos de usuários brasileiros nas redes sociais, pelo então Ibope/Nielsen On-line, em 2010. Foram então identificados cinco tipos de fãs conforme o engajamento:

Figura 10: Tipologia de fãs

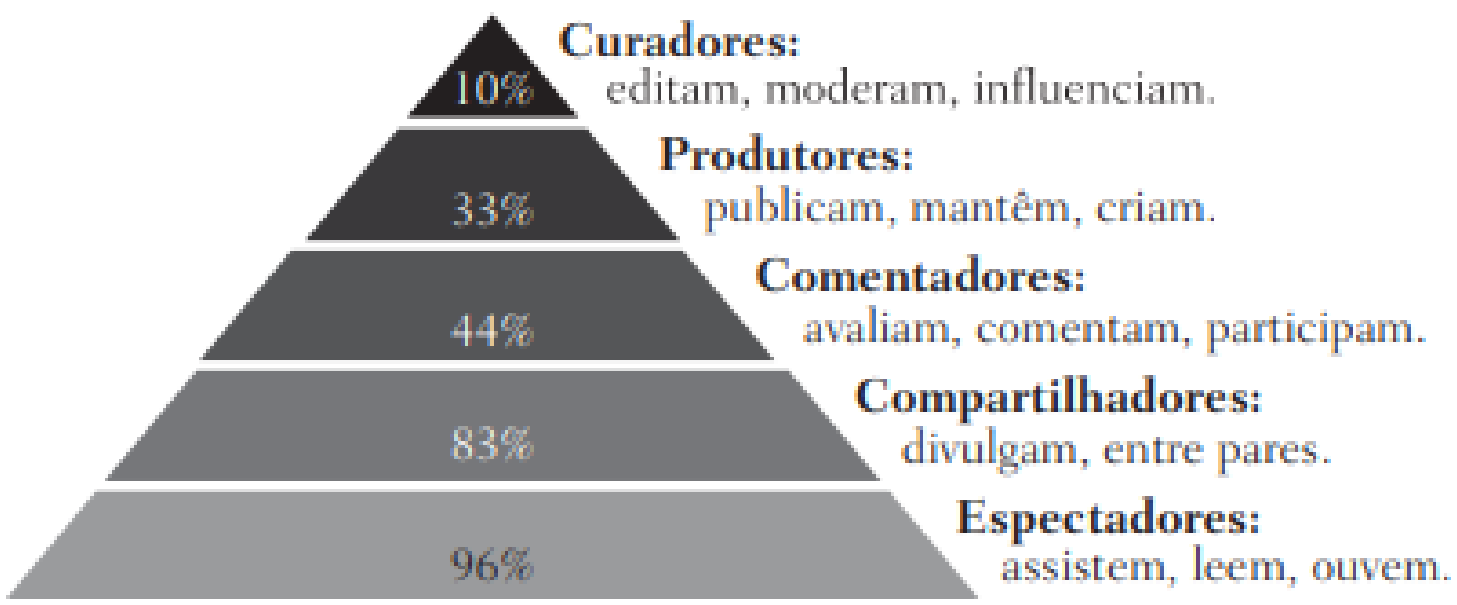

Fonte: LOPES e MUNGIOLI (2011, p. 162) 
Jacks e Ronsini (2011) apontam a participação do receptor diante da circulação de conteúdos sobre a telenovela Passione em produtos midiáticos da Globo e demais veículos de mídia (jornais, revistas, Internet):

Não é arriscado afirmar que, com a perspectiva da transmidiação, o já clássico cruzamento de fronteiras entre o ficcional, o documental, o real e o virtual se atualiza. Em direção similar, a derrocada definitiva da recepção passiva é evidente. Convertido em participante ativo, intervindo efetivamente na construção ampliada da trama, sendo ator decisivo na própria extensão narrativa teleficcional, o espectador deixa de ser mero coadjuvante para assumir um lugar de protagonista essencial na tessitura da transmidiação (JACKS e RONSINI, 2011, p. 342).

Um outro estudo de recepção transmídia foi o estudo de caso sobre as estratégias transmídia de Malhação (Globo, 1995 até os dias de hoje), a única soap opera brasileira em exibição há mais de 20 anos. A ficção recebeu, durante dois anos consecutivos, indicações ao Prêmio Emmy Internacional Digital ${ }^{42}$ :

Entre os destaques em termos de transmídia e expansão da narrativa que contemplaram iniciativas para os hábitos da segunda tela, vivenciados pela audiência da novelinha, está o aplicativo, disponíviel para Androide e iOS, para celular, desktop ou tablet, que começava a funcionar meia hora antes de Malhação ir ao ar e permanecia até pouco depois de sua exibição, repercutindo o capítulo. (LOPES et. al. 2014, p. 155).

A Globo foi a emissora que mais rapidamente seguiu a demanda provocada pelas novas tecnologias digitais, desenvolvendo estratégias transmídia para contemplar os hábitos da audiência e suas novas formas de assistir televisão. Esse movimento começou oficialmente em 2000, com o lançamento do portal globo.com, para conteúdos jornalísticos e de entretenimento (HISTÓRIA GRUPO GLOBO, 2017). A partir de 2003, a emissora elaborou páginas exclusivas para algumas telenovelas, contendo conteúdos simples, como informações de capítulos, galeria de fotos, vídeos, entre outros

\footnotetext{
42 Disponível em: http://g1.globo.com/pop-arte/noticia/2013/02/tv-globo-tem-duas-indicacoes-aopremio-emmy-dig ital- internacional.html Acesso em maio de 2018.
} 
(ALMEIDA, 2018, p. 1428). Desenvolveram e continuam desenvolvendo até a atualidade produtos específicos que possibilitam formas estendidas de interação em horário simultâneo ao período de exibição da ficção ou até mesmo após ele. O empenho da emissora nesse segmento foi se tornando cada vez mais consistente, como com a criação de perfis de personagens de telenovelas em plataformas de redes sociais, como no caso de Ti-Ti-Ti (2008) e a recente Rock Story (2016). Esses perfis fictícios são preenchidos com conteúdo relacionado à trama, mas simulando a performance específica dos personagens.

Voltando ao caso da soap opera Malhação, a emissora também realizou estratégias offline por meio de encontros em capitais brasileiras com "[...] blogueiros, jornalistas e fãs para apresentar novidades transmídia e, ao mesmo tempo, aprender como a cultura jovem no País adota novos hábitos e consumo de mídia. (LOPES, et. al. 2014, p. 158). Em se tratando de estratégias on-line, Passione (Globo, 2010) foi a primeira telenovela a apresentar cenas estendidas exclusivamente para a Internet. Temos ainda os exemplos do blog Sonhos de Luciana da personagem Luciana de Viver a Vida (Globo, 2010), que foi disponibilizado apenas na internet para os receptores da telenovela "em que a personagem da trama interagia com os internautas, provocando, a cada post, centenas de comentários" (LOPES e MUNGIOLI et al., 2014, 152). Devido à demanda configurada pelas novas tecnologias e esse novo ecossistema comunicacional, desde 2012, o Departamento Multiplataforma da Globo investe na produção de conteúdo ficcional original para outras mídias, conteúdos esses que não são extensões ou propagações de suas ficções, na maioria dos casos. Outra estratégia transmídia de grande repercussão foi o clipe musical Vida de Empreguete da telenovela Cheias de Charme (Globo, 2012) que foi disponibilizado no YouTube e "que obteve mais de 10 milhões de visualizações" (Ibdem). A telenovela ainda utilizou o recurso transmídia do lançamento do livro Cida, a empreguete: um diário íntimo, inspirado na personagem de mesmo nome.

Fechine et. al. (2013) categoriza essas estratégias e conteúdos transmídia das telenovelas da Globo como: 
Figura 11: Estratégias e Conteúdos Transmídia

\begin{tabular}{|c|c|c|}
\hline Estratégias & Conteúdos & \\
\hline \multirow[t]{4}{*}{ Propagação } & \multirow{3}{*}{ Conteúdos reformatados } & Antecipação \\
\hline & & Recuperação \\
\hline & & Remixagem \\
\hline & Conteúdos informativos & Contextuais \\
\hline & & Promocionais \\
\hline \multirow{4}{*}{ Expansão } & \multirow{2}{*}{ Conteúdos de extensão textual } & Extensões narrativas \\
\hline & & Extensões diegéticas \\
\hline & \multirow{2}{*}{ Conteúdos de extensão lúdica } & Extensões vivenciais \\
\hline & & Extensões de marca \\
\hline
\end{tabular}

Fonte: FECHINE, et. al. (2013)

Os autores ainda explicam que as estratégias de propagação acontecem por meio de conteúdos reformulados dos capítulos das tramas que são adaptados para outras mídias ou através de conteúdos informativos que oferecem ao receptor informações adicionais sobre a telenovela, por exemplo. As estratégias de expansão, no entanto, “[...] são responsáveis por desdobramentos narrativos. Como o nome sugere, estendem o texto de referência (o programa narrativo principal ou de base) (FECHINE et. al.,2013, p. 44)".

A internet é então colocada como local de integração de ações e linguagens, atua como impulsora para a mudança de hábitos culturais e promotora do consumo cultural, pois "ser internauta aumenta, para milhões de pessoas, a possibilidade de serem leitores e espectadores" (GARCÍA CANCLINI, 2008, p.54). Para Orozco Gómez (2011), o ato de compartilhar um conteúdo na internet ou realizar um simples comentário sobre um programa televisivo, sendo ele ficção ou não, faz com que as audiências, nessa condição comunicacional contemporânea, estejam posicionadas, conforme suas interações com as mais diversas telas, em trânsito, pois de receptivas passam a ser também emissoras. Assim:

[...] Forte impacto da Internet no mercado de mídia tem sido sentido na construção de sistemas alternativos para a circulação de textos da mídia. [...] mudanças fazem alusão a novos modos de produção, gêneros alternativas de conteúdo e novas relações entre produtores e público. (JENKINS, FORD e GREEN, 2013, p. 232). 
Essa liberdade de produção, caracterizada pelo contexto atual de redes e fluxos, faz com que se organizem e publiquem conteúdos por meio das formas socializantes da comunicação. A construção de sentidos realizados por receptores conectados vem ao encontro da tendência contemporânea de trânsito de audiências (OROZCO GÓMEZ, 2011) em que o consumo televisivo é amplificado a outra instância. A recepção toma, algumas vezes, ares produtivos, aproximando-se das lógicas de produção de conteúdo e colocando em xeque a linearidade da emissão midiática. Desta forma:

a sala da casa está amplificada e comentar a telenovela, hábito tão enraizado na cultura brasileira, parece ganhar, cada vez mais, novos adeptos. A ritualidade de ligar a TV se estende à outra tela e as duas não competem, se complementam" (DEPEXE, 2015, p. 208-209).

A rede social Twitter é um dos exemplos sobre esse comportamento migratório das audiências especialmente durante a exibição das ficções, segundo Highfield, Harrington e Bruns (2013). A rede social permite aos fãs descrever e compor suas próprias narrativas sobre eventos transmitidos pela televisão em 140 caracteres, que são mais do que suficientes para expressarem gostos, posições e produzirem sentidos. Church e Oliveira (2013) e Canatta (2014) afirmam que a grade fixa da TV participa e constrói interações de usuários no Twitter, e as discussões entre usuários na rede social acompanham, em diferentes graus, a sequência de programas da grade televisiva:

A conversação em torno de uma atração pode começar horas antes da exibição e seguir por muito tempo depois do término da transmissão. A discussão provocada pela programação da televisão se tornou um processo contínuo, cujo ápice permanece durante a exibição do show. Verifica-se assim a importância da grade de programação na orientação da conversa ao se constatar que a alteração na lista dos assuntos mais comentados acompanha, em menor ou maior grau, a sequência de programas da grade televisiva (CANATTA, 2014, p. 109).

Ainda sobre o Twitter, a rede social permite interação, por vezes indireta, com a telenovela e não uma efetiva participação, no sentido descrito por Jenkins (2009), afinal, 
pode-se comentar sobre a telenovela, estabelecer conversação com outros usuários/receptores, mas não há autonomia para o usuário modificar a trama da ficção. Porém:

ao ver outros usuários comentando o mesmo programa de televisão, a aparência de uma participação - comunhão de sentimentos e opiniões supera a lógica da interação, especialmente se a produção midiática monitorar o que é dito em prol da conquista e manutenção das audiências (DEPEXE, 2015, p. 114).

As possibilidades ofertadas pela transmidiação através dessa rede social foi estudada por Depexe (2015), em que a autora explorou a circulação e o consumo da telenovela Salve Jorge (Globo, 2012) no Twitter para compreender o fenômeno do consumo simultâneo TV-internet e o funcionamento da palavra "periguete" na comunicação e distinção de classe. Como resultados, a pesquisadora destaca que a forma-sujeito "periguete" funciona como uma posição de sujeito cujos sentidos são móveis, mas remetem à liberdade do corpo feminino, seja na maneira como se veste e nos cuidados estéticos, seja no exercício de sua sexualidade. Todas essas questões foram passíveis de serem analisadas nos apenas 140 caracteres disponibilizados pela rede social para que os usuários escrevam na rede social.

Já foi observado, ao longo dos anos, que algumas hashtags criadas pelos usuários podem se tornar muito conhecidas no país inteiro, estarem na pauta de inúmeras conversações que extrapolam a telenovela e perdurar até muito depois da exibição da ficção. Tais indicadores apontam para o comportamento migratório das audiências (JENKINS, 2009; OROZCO GÓMEZ, 2011) e reforçam o caráter ativo do consumo midiático em que os receptores buscam as experiências que desejam, tornam público tanto seus gostos quanto suas contestações (JENKINS, 2009).

Conforme Lopes e Mungioli (2013), a telenovela Avenida Brasil (Globo, 2012) marcou a história da televisão brasileira no que se refere ao engajamento da audiência com a trama, repercutindo de maneira surpreendente no contexto de disseminação das audiências e consumo de conteúdos em multiplataformas. A temática da ficção expandiu por toda a grade da Globo, incluindo programas jornalísticos e debates, além da migração para a grade de outras emissoras. E às vésperas da exibição do último capítulo da telenovela na TV, as hashtags \#avenidabrasil e \#oioioi (+ o número do 
capítulo) foram, ao longo da última semana de exibição da telenovela, Trending Topics mundiais no Twitter (Ibdem, 2013).

Todo esse cenário de convergência, de transmidiação e de globalização cultural motivou, desde 2010, o OBITEL (Observatório Ibero-Americano da Ficção Televisiva) a incluir em seu monitoramento anual as observações sobre a transmidiação em cada país, dependendo das particularidades e diferentes narrativas ficcionais televisivas em distintos meios como cinema, internet, televisão, telefone celular, videogames e DVD, bem como em diversas plataformas, como televisão aberta, fechada (via cabo ou satélite) e streaming. Isto analisado nos diferentes formatos como telenovela, série, minissérie, unitário, docudrama, acompanhado pelo surgimento das práticas de fãs que, a partir do que assistem, criam suas próprias narrativas sobre a ficção que acompanham, rompendo a dualidade receptores/emissores (LOPES e OROZCO GÓMEZ, 2010, p.19). No Anuário de 2010, os autores esclarecem que a transmidiação já acontecia antes dos meios virtuais, mas que esta foi acelerada com a chegada deles.

Assim os novos produtos como sites, blogs, redes sociais e jogos, por exemplo, permitem expandir as narrativas em outras mídias. Essas novas possibilidades narrativas iniciam unidas à esfera da produção e com o objetivo de compreender os movimentos do mercado diacrônicos entre a oferta e o consumo de produtos midiáticos. No caso da telenovela, os estudos se voltam à esfera que detém tanto o controle da ficção quanto dos produtos a ela vinculados. São examinadas, assim, as estratégias das emissoras de televisão e os espaços criados para permitir interação com as suas audiências, e dão início à já mencionada outras vezes neste capítulo, recepção transmidiática. As ações empreendidas pela audiência em outros espaços que não só a televisão, são, ainda que timidamente, identificadas em raras pesquisas, como por exemplo, em Lopes et al. (2009), ao tratar de blogs, comunidades do Orkut e perfis do Twitter.

No Anuário do ano seguinte, o Obitel (LOPES e OROZCO GÓMEZ, 2011) inclui a recepção transmidiática como um tópico a ser investigado, mas ainda de caráter exploratório, para analisar as "novas formas em que as audiências se relacionam e se vinculam com a ficção televisiva que agora assistem e consomem pela internet ou por meio de dispositivos móveis, como celulares, laptops, ipods etc.” (Ibdem, p.17). O conceito de transmidiação é atrelado à esfera produtiva midiática como parte de uma estratégia para envolver o público com uma narrativa ficcional. Então, "uma história 
transmídia desenrola-se através de múltiplas plataformas de mídia, com cada novo texto contribuindo de maneira distinta e valiosa para o todo" (JENKINS, 2009, p.138).

Em 2012, o OBITEL incorporou às práticas metodológicas dos anuários a partir de então, o tópico recepção transmidiática. Naquele ano Lopes e Mungioli (2012) estudaram as interações entre fãs dos dez títulos mais assistidos na internet, principalmente no Facebook, no Twitter e no site oficial das emissoras. O estudo de caso foi a telenovela Cordel Encantado (Globo, 2011):

destaque em termos estéticos e narrativos, Cordel Encantado
consolidou-se pela movimentação gerada na internet. As comunidades
elucidam as estratégias interativas dos fãs, que, apesar da restrição de
práticas no site oficial da telenovela, constroem espaços de sentido e
de agrupamento em que a telenovela pode ser comentada,
compartilhada e elogiada (Ibdem, p. 174).

A partir do que é exposto no Anuário 2013 (LOPES e OROZCO GÓMEZ, 2013), não só os estudos acerca da recepção transmidiática são emergentes, mas também a própria visão das empresas produtoras de ficção televisiva sobre as capacidades criativas das audiências que ainda é pautada pelo interesse mercadológico e de lucro. A recepção transmidiática foi observada a partir do fenômeno, já citado, Avenida Brasil (Globo, 2012), recorde de engajamento e interações nas redes sociais.

No Anuário de 2014, os autores afirmaram que transmidiação, "embora emergente, traz consigo um alto potencial de entendimento da própria produção e das expectativas com a ficção, sua distribuição e consumo pelas empresas e canais de televisão" (LOPES e OROZCO GÓMEZ, 2014, p.17). Os pesquisadores destacaram as mudanças nas estratégias da Globo quanto à divulgação de suas ficções no Facebook com o fim das inúmeras fanpages dedicadas às telenovelas em que o conteúdo foi centralizado em um só fanpage, a Gshow. A emissora utilizou a mesma estratégia com relação às informações sobre as ficções nos seus perfis oficiais (@rede_globo e @Gshow). As principais interações com a audiência aconteceram com a telenovela Amor à Vida (Globo, 2013), tanto nos perfis oficiais e na página da emissora nas redes como também com ao perfil pessoal do autor da ficção. Os investigadores observaram uma grande quantidade de visualizações e interações em uma fanpage criada por um fã no Facebook um dia após a estreia da telenovela, o Félix Bicha Má, em que 
"aproximadamente dois milhões de pessoas falavam sobre o assunto na fanpage" (Ibdem, p. 144).

Em 2015, o Observatório Ibero- americano de Ficção Televisiva, no que concerne à recepção transmídia, continuou apontando para as tendências observadas anteriormente sobre as mudanças e implantação de novas estratégias transmídias por parte das emissoras tanto para a produção quanto na recepção de conteúdos para "provocar/desafiar a participação e a criatividade das audiências. Ganham corpo nesse contexto as interações por meio de redes sociais nas quais os fãs comentam e compartilham conteúdo de televisão, sobretudo em regime de multitarefas (LIVINGSTONE, 2011)" (LOPES e OROZCO GÓMEZ, 2015, p. 141). Segundo os pesquisadores, naquele ano, o destaque foi a prática de shipping por parte dos fãs de ficção:

[...] como nova forma de relacionamento dessas audiências com os personagens ficcionais. $\mathrm{O}$ termo ship, derivado do inglês relationship, teve origem em fóruns de discussão e redes sociais na internet e refere-se à junção parcial dos nomes dos casais de personagens com os quais os fãs mais se identificam (Amaral, 2014, p. 9). Assim, shippar um casal consiste principalmente em criar hashtags com os nomes dos personagens que indexarão todo o conteúdo produzido pelos fãs nas redes (LOPES e OROZCO GÓMEZ, 2015, p. 142).

A shippagem era estimulada pela emissora e praticada pelos fãs principalmente nas ficções Malhação (Globo, 2014) e Império (Globo, 2014).

No Anuário de 2016, o destaque de recepção transmídia foi o Twitter como plataforma preferida pelos fãs de ficção televisiva para interagir, conversar e criar conteúdos acerca de seus temas de interesse e ficção assistida. Foram salientadas a criação de memes, hashtags, fanfics, remixes, ships reforçando que o universo criativo dos fãs ganha cada vez mais força e se consolida em diversas plataformas conforme o panorama digital atual. As ficções mais comentadas e com maior número de hashtags foram Império (Globo, 2015) e Verdades Secretas (Globo, 2015).

Em 2017, o Anuário trouxe como discussão sobre a recepção transmídia no Brasil o desenvolvimento e consolidação cada vez mais sofisticado das ações transmídia. Os pesquisadores afirmaram que as estratégias exitosas junto ao público continuaram a ser implantadas pelas emissoras bem como houve um maior surgimento de expansões das narrativas ficcionais para além da grade televisiva. Foram salientados 
os spin-offs (técnica de extensão da história em outra plataforma que acrescenta pormenores não abordados na trama principal) nas telenovelas Totalmente Demais, Haja Coração e Liberdade, Liberdade, todas da Globo. O OBITEL também observou, no Anuário de 2017, a série Supermax (Globo, 2016), que possibilitou a criação de um game desenvolvido exclusivamente por estudantes e que, após cada episódio ser exibido na TV, os níveis do jogo eram desbloqueados. "O jogo teve 401.145 downloads, tanto no Brasil como em outros países, como Estados Unidos, Angola, Japão, Portugal e Reino Unido (LOPES e GRECO et al., 2017, p.114).

No ano de 2018, o OBITEL detectou que o destaque nas redes sociais foi a telenovela A Força do Querer (Globo, 2017) devido ao espalhamento dos conteúdos acerca da trama. Conforme a Kantar Ibope Media a telenovela teve maior repercussão no Twitter, em 2017, "registrando mais de 829 milhões de impressões por meio de 6 milhões de tweets" (LOPES e GRECO et al., 2018, p. 123). Ainda de acordo com o observatório, o último capítulo da trama esteve oito vezes no trending topics mundiais (assuntos que são tendência na plataforma) e 30 vezes nos assuntos mais comentados do Brasil.

No ano seguinte, o observatório pontuou a grande interação do público através das redes sociais Instagram, YouTube, Twitter e Facebook, com a reprise da telenovela Vale Tudo (Globo, 1988) no Canal Viva. Além disso, houve destaque, como já mencionamos no primeiro capítulo desta tese, sobre a telenovela das 21h Segundo Sol (Globo, 2018). A trama "foi destaque em impressões no Twitter, com aproximadamente 4 milhões de tweets e mais de 646 milhões de impressões (número de vezes que uma postagem foi visualizada) (LOPES e PREZIA et al., 2019, p. 96).

O engajamento e a emotividade, essenciais para as atividades nas redes sociais digitais, levam as audiências a assumirem a internet como espaço de expressão, indiciando os modos pelos quais consomem e se apropriam das telenovelas e séries. É um tipo de circulação de fluxo livre. O engajamento do receptor é fundamental para a concretização do texto transmidiático, pois, sem este engajamento, sem a disponibilidade do espectador para acessar os conteúdos televisivos transmídia:

a estratégia transmídia não consegue efetivar seu processo de produção de sentido. Cada conteúdo complementar permaneceria 
solto, disperso; em vez de formar um todo, com unidade própria e maior do que a soma das partes, que é o objetivo maior dos projetos transmídias (JENKINS, 2008; SCOLARI, 2013 apud ALMEIDA, 2018, p. 1672).

A análise de Aquino e Puhl (2011) sobre a repercussão da reprise da telenovela Vale Tudo (Globo, 1988) indica que o Twitter serviu à interação entre consumidores na internet e à disseminação de conteúdo sobre a ficção. Além dos comentários feitos pelos receptores, as autoras encontraram perfis dos personagens da telenovela, criados e mantidos por usuários da rede social. Desta forma, afirmam que "os comentários feitos no Twitter sobre a telenovela sustentam a hipótese de que a convergência das mídias TV e web potencializam a visibilidade do conteúdo ficcional, além de permitir a construção de novos significados em relação à narrativa" (Ibdem, p.35). Jacks et al. (2012) estudaram os perfis de personagens de Passione (Globo, 2010), páginas e blogs que se declaram oficiais da Globo, mesmo sendo criados e mantidos por telespectadores, e perceberam que, em muitas vezes, acontece que "a narrativa sai do controle do âmbito da produção e passa a circular de maneira imprevisível pelos fluxos criados pelos próprios consumidores nessas plataformas" (Ibdem, 2012, p.205).

Sifuentes, Vilela e Jeffman (2012) fazem uma síntese das apropriações dos receptores de Avenida Brasil (Globo, 2012) nas redes sociais digitais Facebook, Twitter e Tumblr, e enfatizam os perfis e conversações de personagens, bem como o grande volume de citações dos bordões da telenovela, as fotomontagens e a incorporação do efeito "congelado" 43 aos avatares pessoais dos usuários. A mesma telenovela foi objeto de estudo de Bortolon, Regattieri e Malini (2013), que avaliam, através da ARS (Análise de Redes Sociais), quais perfis do Twitter se destacaram na conversação a respeito da trama. Oikawa, John e Avancini (2012) se dedicaram a realizar uma comparação do conteúdo em circulação na internet das telenovelas Passione (Globo, 2010) e Avenida Brasil (Globo, 2012). Segundo as autoras, "a circulação e geração de conteúdos que expandem a narrativa por parte dos receptores via redes sociais online é intensa e muitas vezes obriga a esfera da produção a adotar as estratégias que, originalmente, surgiram entre os receptores" (Ibdem, 2012, p.117). Dentre essas

\footnotetext{
${ }^{43}$ No momento final de cada capítulo de Avenida Brasil, o personagem em cena torna-se uma fotografia em preto e branco, com um fundo desfocado. Através de tutoriais espalhados pela rede, personalidades e anônimos editaram fotos pessoais comessa estética, divulgando pela internet, em seus avatares nas redes sociais digitais, como Twitter, Facebook, entre outros (SIFUENTES, VILELA, JEFFMAN 2012).
} 
estratégias, as autoras citam as fotomontagens e os gifs animados com personagens, frases e cenas da telenovela.

Ao mesmo que redes sociais digitais têm suma importância nos processos de transmidiação e interação da ficção televisiva com suas audiências, é evidente também que, junto a esta possibilidade de marketing gratuito para as emissoras e suas ficções, há também o risco de que essa voz dos receptores carregadas de impressões, opiniões e produção de sentido possa também servir como uma contrapropaganda a um produto de mídia. Almeida (2018, p. 1422) declara que "A convergência seria, então, uma dinâmica constante de tensão e transformação, que envolve indústria e consumidores, levando a decisões estratégicas e resultados por vezes imprevisíveis". Por isso há um crescente esforço das emissoras em produzir conteúdo, experienciar e transformar suas relações com a audiência para minimizar qualquer tipo de opiniões desfavoráveis ou reações polêmicas contra suas ficções.

Assim, seja pela criação de uma agenda, muitas vezes, disfarçada de conversação, seja pela apropriação de práticas dos receptores na rede, as

empresas midiáticas estão aprendendo a acelerar o fluxo de conteúdo midiático pelos canais de distribuição para aumentar as oportunidades de lucros, ampliar mercados e consolidar seus compromissos com o público (JENKINS, 2009, p.46).

O compromisso com o público, aliado à necessidade de lucro das emissoras de TV, deixa evidente a necessidade das empresas em conquistar e manter os elevados índices de audiência além de abrir caminho para as especulações sobre a influência que o receptor tem sobre as narrativas ficcionais. Exemplo dessas manifestações contrárias do público frente a uma ficção televisa foi descrito no trabalho, já citado de Jacks e Ronsini et al. (2011), em que as autoras encontraram opiniões contrárias à personagem Diana, construída como heroína de Passione (Globo, 2010) e favoráveis à vilã Clara, as quais teriam contribuído para alterar o desfecho da trama:

A hipótese é que essa rejeição da personagem por parte da audiência culminou na mudança da narrativa que a levou à morte, enquanto que Clara, apesar de antagonista, foi a mais amada pelo público e teve final feliz (Ibdem, p.332). 
Levando em consideração os cinco volumes da Coleção Teledramaturgia ${ }^{44}$, que reúne trabalhos realizados pelos pesquisadores da Rede Obitel Brasil, constatamos que, entre os 44 artigos publicados, somente onze pesquisas incluíram em suas discussões as atividades dos receptores, sendo que nove artigos (JACKS e OIKAWA et al., 2013; JACKS e RONSINI et al., 2011; BACCEGA e CASTRO, 2017; RONSINI e BRIGNOL, 2017; JACKS e SIFUENTES, 2017; LOPES e PREZIA et al., 2019; SOUZA et al., 2019; BORGES BRANDÃO e FARIA et al., 2019; FECHINE et al., 2019) abordaram as ações dos telespectadores desvinculadas de ambientes digitais controlados pela instância emissora da telenovela.

Em programas de pós-graduação brasileiros, ainda são poucas as pesquisas que tencionam a recepção da transmídia da telenovela. Apresentaremos um apanhado conforme os últimos dez anos de investigações, período em que os estudos de recepção de telenovela e internet/ convergência/transmídia começaram a ser realizados com maior frequência. Apesar de mais da metade dessas pesquisas da última década terem como meio mais estudado somente a televisão (JACKS et al. 2014, p. 31), os trabalhos atuais já se voltam, ainda que em menor volume, para as questões relacionadas à internet, como a convergência midiática. Isso responde à demanda imposta por essa nova configuração do ecossistema midiático em voltar o olhar dos estudiosos para as novas tecnologias, mas também responde à evolução de ferramentas digitais que possibilitam tais pesquisas. Ou seja, "os suportes comunicacionais adotados para o uso das técnicas de coleta de dados ganharam um reforço extremamente útil" (JACKS et al. 2017, p. 133).

Sobre esses estudos realizados pelos pesquisadores que defenderam suas dissertações de Mestrado e teses de Doutorado nos últimos dez anos, no país, desenvolvemos um quadro com as principais informações, como por exemplo, quais são essas pesquisas, seus autores, instituições e ano de defesa dos trabalhos:

\footnotetext{
${ }^{44}$ LOPES, M. I. V. (Org.) Ficção televisiva transmidiática no Brasil: plataformas, convergência, comunidades virtuais. Porto Alegre: Sulina, 2011; _____. Estratégias de transmidiação na ficção televisiva brasileira. Porto Alegre: Sulina, 2013; ______. Por uma teoria de fãs da ficção televisiva. Porto Alegre: Sulina, 2015; ________. Por uma teoria de fãs da ficção televisiva II: práticas de fãs no ambiente da cultura participativa. Porto Alegre: Sulina, 2017; _____________. A construção de mundos na ficção televisiva brasileira. Porto Alegre: Sulina, 2019.
} 
Quadro 1- Teses e dissertações defendidas sobre recepção de tele novela e internet/convergência/trans mídia a partir de $\mathbf{2 0 1 0}$

\begin{tabular}{|c|c|c|c|c|}
\hline TÍTULO & ANO & $\overline{\text { AUTOR }}$ & NIVEL & $\begin{array}{l}\text { INSTITUIÇĀO/ } \\
\text { ESTADO }\end{array}$ \\
\hline $\begin{array}{l}\text { Telenovela } \\
\text { identidade nacional no } \\
\text { ciberespaço: } \\
\text { explorações } \\
\text { metodológicas da } \\
\text { recepção internacional } \\
\text { de Caminho das Índias } \\
\text { em comunidades } \\
\text { virtuais }\end{array}$ & 2010 & $\begin{array}{l}\text { Denise de } \\
\text { Oliveira } \\
\text { Freire }\end{array}$ & Mestrado & USP/SP \\
\hline $\begin{array}{l}\text { A tecnicidade como } \\
\text { mediação empírica: a } \\
\text { reconfiguração da } \\
\text { recepção de telenovela } \\
\text { a partir do Twitter }\end{array}$ & 2013 & $\begin{array}{l}\text { Mônica } \\
\text { Pieniz }\end{array}$ & Doutorado & UFRGS/RS \\
\hline $\begin{array}{lr}\text { O discurso } & \text { sobre } \\
\text { homossexualidade } & \text { em } \\
\text { Insensato } & \text { Coração: } \\
\text { ressonância } & \text { nos } \\
\text { comentários- } & \\
\text { fragmentos } & \\
\text { discursivos- } & \text { de } \\
\text { internautas } & \text { em } \\
\text { websites } & \\
\end{array}$ & 2013 & $\begin{array}{l}\text { Plábio } \\
\text { Marcos } \\
\text { Martins } \\
\text { Desidério }\end{array}$ & Doutorado & $\mathrm{UnB} / \mathrm{DF}$ \\
\hline $\begin{array}{lr}\text { Função educativa da } \\
\text { telenovela brasileira: } \\
\text { do merchandising } \\
\text { social à } & \text { ação } \\
\text { socioeducativa } & \text { em } \\
\text { Salve Jorge } & \\
\end{array}$ & 2013 & $\begin{array}{c}\text { Silvia } \\
\text { Terezinha } \\
\text { Torreglossa } \\
\text { de Jesus }\end{array}$ & Mestrado & USP/SP \\
\hline $\begin{array}{l}\text { Comunicação, } \\
\text { consumo e educação- } \\
\text { os discursos sobre } \\
\text { ciência na telenovela } \\
\text { Morde \& Assopra: } \\
\text { uma aventura } \\
\text { interdisciplinar sobre } \\
\text { aprender, apreender, } \\
\text { ouvir e contar histórias }\end{array}$ & 2013 & $\begin{array}{c}\text { Andrea } \\
\text { Celeste } \\
\text { Montini } \\
\text { Antonacci }\end{array}$ & Mestrado & ESPM/SP \\
\hline $\begin{array}{lrr}\text { Entre } & \text { espaços, } & \text { uma } \\
\text { novela: teletopias } & \text { de } \\
\text { uma \#avenida } & \text { em } \\
\text { trânsito } & & \\
\end{array}$ & 2014 & $\begin{array}{c}\text { Rafael } \\
\text { Fonseca } \\
\text { Drumond }\end{array}$ & Mestrado & $\overline{\mathrm{PUC} / \mathrm{MG}}$ \\
\hline Blogs de personagens & 2014 & José & Mestrado & UFPB/PB \\
\hline
\end{tabular}




\begin{tabular}{|c|c|c|c|c|}
\hline $\begin{array}{l}\text { de telenovelas: } \\
\text { convergências entre o } \\
\text { real e o ficcional }\end{array}$ & & $\begin{array}{l}\text { Glaydson } \\
\text { Pereira de } \\
\text { Souza }\end{array}$ & & \\
\hline $\begin{array}{l}\begin{array}{l}\text { Distinção em } 140 \\
\text { caracteres: } \\
\text { social, telenovela e } \\
\text { Twitter }\end{array}\end{array}$ & 2015 & $\begin{array}{l}\text { Sandra } \\
\text { Depexe }\end{array}$ & Doutorado & UFSM/RS \\
\hline $\begin{array}{l}\text { Da veiculação em } \\
\text { fluxo contínuo para a } \\
\text { disponibilização: } \\
\text { gancho na produção } \\
\text { de sentido da } \\
\text { telenovela Avenida } \\
\text { Brasil }\end{array}$ & 2016 & $\begin{array}{l}\text { Luis } \\
\text { Enrique } \\
\text { Cazani } \\
\text { Júnior }\end{array}$ & Mestrado & UNESP/SP \\
\hline $\begin{array}{l}\text { Audiência transmídia: } \\
\text { uma proposta de } \\
\text { conceituação a partir } \\
\text { das telenovelas da } \\
\text { Rede Globo }\end{array}$ & 2016 & $\begin{array}{c}\text { Marcela } \\
\text { Costa da } \\
\text { Cunha } \\
\text { Chacel }\end{array}$ & Doutorado & UFPE/PE \\
\hline $\begin{array}{lcr}\text { Televisão } & \text { e } & \text { redes } \\
\text { sociais: } & \text { configurações } \\
\text { de TV } & \text { Social } & \text { em } \\
\text { Malhação } & & \end{array}$ & 2016 & $\begin{array}{c}\text { Gêsa Karla } \\
\text { Maria } \\
\text { Cavalcanti }\end{array}$ & Mestrado & UFPE/PE \\
\hline $\begin{array}{l}\text { A memória afetiva e } \\
\text { os telespectadores : } \\
\text { um estudo do Canal } \\
\text { Viva }\end{array}$ & 2017 & $\begin{array}{l}\text { Mario Abel } \\
\text { Bressan } \\
\text { Junior }\end{array}$ & Doutorado & PUC/RS \\
\hline $\begin{array}{l}\text { Telenovela, } \\
\text { comunidade de } \\
\text { recepção e ambientes } \\
\text { de sociabilidade online: } \\
\text { luto e sentimento de } \\
\text { perda como elementos } \\
\text { de evidência e e } \\
\text { fortalecimento de laços } \\
\text { sociais na experiência } \\
\text { televisiva }\end{array}$ & 2017 & $\begin{array}{c}\text { Júnia } \\
\text { Cristina } \\
\text { Ortiz Matos }\end{array}$ & Doutorado & UFBA/BA \\
\hline
\end{tabular}

Fonte: Banco de dados de teses e dissertações do CETVN ${ }^{45}$ e JACKS et al. (2017)

Percebemos, pelo quadro acima, que, nos últimos anos, foram defendidos poucos trabalhos sobre recepção de telenovela e internet/convergência/transmídia. Ao

\footnotetext{
${ }^{4}$ Esse banco de dados do CETVN foi criado em 2007, através do Projeto de Levantamento, classificação $e$ análise de dados referentes a teses e dissertações sobre ficção televisiva nos programas de PósGraduação em Comunicação do brasil.
} 
todo foram 9 trabalhos, sendo destes a maioria dissertações de mestrado. O que só confirma o fato de que é preciso que se investigue ainda mais esse novo cenário imposto pelas tecnologias digitais.

A dissertação de Freire (2010) investigou a telenovela e a identidade nacional no ciberespaço atentando para as explorações metodológicas da recepção internacional de Caminho das Índias (Globo, 2009) em comunidades virtuais. A pesquisadora concluiu que "Agrupados no Brasil territorializado virtualmente em Portugal, uma parcela dos internautas estabelece vínculos afetivos suficientes para o estabelecimento de comunidades virtuais da nação, assim como aqueles que se agrupam em torno da ficção seriada televisiva, nas comunidades de telenovela" (FREIRE, 2010, P. 158). Através do deslocamento dos temas da trama para as discussões no ciberespaço, a pesquisadora verificou que o imaginário brasileiro difundido pela "narrativa da nação" (LOPES, 2003) atua na preservação da identidade e na manutenção tanto das culturas nacionais quanto locais. A tese de Pieniz (2013) busca compreender as motivações dos tweeteiros, e a autora concluiu que "a tecnicidade operacionalizada na ideia de forças de montagem dos meios, vem permitindo a emergência de novas sociabilidades a partir das relações estabelecidas no contexto da convergência midiática" (PIENIZ, 2013, p. 166).

A pesquisa de Desidério (2013) visava compreender o discurso na telenovela Insensato Coração (Globo, 2011) sobre homoafetividade, a partir da prática do merchandising social e da sua ressonância entre os fragmentos discursivos dos internautas em websites, como Orkut e Folha.Uol e Yahoo!. A partir da análise de fragmentos discursivos, o autor concluiu que os sujeitos virtuais usam significados virtuais para escrever sobre homoafetividade na telenovela estudada "e que as representações sociais presentes nas formações discursivas os condicionaram a produzir e reproduzir discursos sobre homoafetividade que circulam no espaço não virtual [...]” (DESIDÉRIO, 2013, p. 221). Jesus (2013) estudou a articulação entre merchandising social e a função educativa na telenovela como geradora de pautas para a imprensa e de temas de conversação nas redes sociais. A autora pesquisou sobre as conversações sobre Salve Jorge (Globo, 2012) no Facebook, e segundo ela, as cenas de merchandising social amplamente utilizadas na telenovela "como forma de orientação para a população a respeito de assuntos polêmicos nem sempre é discutido nas redes sociais com tamanho ênfase como é tratado na mídia 
hegemônica, onde ainda pautam reportagens, debates e até criação de leis e medidas" (JESUS, 2013, p. 108).

A pesquisa de Antonacci (2013) enfocou as narrativas sobre ciência presentes na telenovela Morde \& Assopra (Globo, 2011) e no blog Caçadora de Dinossauros (constituinte da trama) como elementos-chave para a análise do consumo de tais discursos e sua ressignificação pelos estudantes do Ensino Fundamental. Segundo a autora, foi possível perceber a presença das matrizes culturais, tanto na recepção da narrativa da telenovela quanto no blog por parte dos alunos, além do que "As lógicas da produção também foram evidenciadas como mediadoras do processo, orientando a "televidência" e a leitura do blog" (ANTONACCI, 2013, p. 150). A dissertação de mestrado de Drumond (2014) examina tweets coletados sobre Avenida Brasil (Globo, 2012) com a intenção de mapear, através de análise textual, as motivações dos receptores em três fases da telenovela: estreia, centésimo capítulo e desfecho. Afirma que a potência verificada na telenovela residiu na "vinculação, na promoção de formas de estar junto, na valia interativa, enfim, na espacialização de sujeitos e sociedade em torno de uma mesma teletopia (DRUMOND, 2014, p. 175).

Souza (2014) investigou o processo de transmidiação das telenovelas na internet e as convergências entre o ficcional e o real a partir do Blog do Indra de Caminho das Índias (Globo, 2009). A partir das postagens no blog, o autor investigou como eram construídas a identidade do personagem bem como o perfil identitário do público. A conclusão foi que a identidade do personagem se fazia a partir de estratégias discursivas que simulavam a existência de um blogueiro do mundo real bem como o perfil identitário do público internauta projetado em função dessa mesma perspectiva. Além do que o público se identificava com o personagem e criava vínculos com o ficcional compartilhando, assim como o personagem, suas próprias histórias. A tese de doutorado de Depexe (2015) sobre o Twitter e a distinção de classe social a partir dos personagens femininos já foi mencionada nesse capítulo e faz parte dos trabalhos defendidos sobre recepção transmíd ia nestes últimos dez anos.

Cazani Júnior (2016) estudou a utilização do gancho em matrizes de linguagem e seus efeitos de sentido, associando esses a aspectos como a peripécia, o reconhecimento e a catástrofe da tragédia grega, bem como aos golpes teatrais do melodrama, ao corte sistemático do romance-folhetim, ao clímax, à pinça, aos tempos fortes e à instauração de pontos de virada. $\mathrm{O}$ autor afirma que "O que realmente cativou 
a audiência na primeira fase dessa telenovela foi o percurso de Rita, um verdadeiro gancho. Os riscos vividos por uma criança à mercê da própria sorte se destacaram facilmente perante os outros eventos, como denotado pela análise de visualizações" (CAZANI JÚNIOR, 2016, p. 118).

Chacel (2016) desenvolveu a tese com o objetivo de conceituar e descrever a audiência transmídia. Para isso, fez um levantamento bibliográfico sobre o conceito de audiência e os métodos de mensuração desta, pontuando os limites e desafios perante os fenômenos proporcionados pela cultura participativa. A autora realizou uma pesquisa empírica quantitativa com telespectadoras de telenovela em Recife, Pernambuco. Concluiu que "o engajamento é a condição sine qua non para constituição de uma audiência transmídia, o que implica em um investimento de tempo, de atenção e envolvimento emocional em diferentes graus para a realização deste 'trabalho' de finalização da textualização" (CHACEL, 2016, p. 159, grifos da autora). Definiu quatro níveis de engajamento: articulação, participação, colaboração e produção de fã, "que distingue fundamentalmente a audiência transmídia do que se pode considerar apenas como uma audiência multitela ou multiplataforma" (Ibdem).

A pesquisa de Cavalcanti explorou a nova experiência interacional entre os telespectadores e a televisão possibilitada pelas tecnologias digitais, chamada de TV Social. O objetivo da autora foi conceituar este fenômeno e delimitar este tipo de experiência por meio de uma pesquisa exploratória-descritiva em que analisou os diferentes conceitos e significados de TV Social e suas recorrências nos campos da Tecnologia e Comunicação. Foram analisadas três temporadas de Malhação (Globo, 2013,2014,2015) para identificar as estratégias de TV Social utilizadas e encontradas seis diferentes tipos: hashtags diárias, aplicativo Malhação, Malhação no Ar, chats com o elenco e gratificações. A autora ressalta que a TV Social é "claramente uma estratégia de reforço da lógica da programação que sustenta o modelo broadcasting" (CAVALCANTI, 2016, p. 174), além do que "permite ou o uso de espaços próprios ou o estímulo do uso de outras plataformas para permitir tais interações, mas diferente do 'comentar' no YouTube a TV Social está, principalmente, voltada para o 'ao vivo' (Ibdem, p. 175, grifos da autora). A TV Social é parte de um projeto transmídia, mas por possuir características próprias, pode ser identificada como parte específica dentro da cultura participativa. 
Bressan Junior (2017) investigou como é constituída a memória teleafetiva dos telespectadores do Canal Viva, analisando como a audiência é conquistada pelo canal, quem é esta audiência nas redes sociais e que memórias e afetos aparecem em suas publicações. O autor utilizou a análise de conteúdo para a analisar os comentários sobre as telenovelas Cambalacho (1986) e Laços de Família (2000), da Globo, postados pelos telespectadores do canal na rede social Twitter. Como resultado, afirma que "além das afetividades que cada telespectador manifesta ao assistir as telenovelas no Canal Viva, há uma teleafetividade que predomina e justifica a audiência do canal' (BRESSAN JUNIOR, 2017, p. 168). Acrescenta que a televisão recria um laço social e faz com que os receptores se sintam voltando no tempo ao assistir as reprises das telenovelas, mobilizando suas emoções.

A pesquisa de Matos (2017) buscou compreender a relação entre a recepção e o conteúdo televisivo propiciados pela sociabilidade on-line. Para isto, investigou o uso de sites e redes sociais como dispositivos de conversação instantânea e sua ligação com o consumo televisivo a partir de comunidades on-line de fãs/telespectadores. Realizou uma análise etnográfica de grupos formados para discussão da telenovela Velho Chico (Globo, 2016) no WhatsApp e Facebook. A pesquisa evidenciou a importância do contexto comunicativo para a compreensão das práticas interativas em comunidades online, bem como os efeitos da Espiral do Silêncio para a construção de gosto. Evidenciou ainda o fortalecimento dos laços sociais na experiência televisiva com os processos de luto e sentimento de perda em relação à narrativa e também ao grupo em que a sociabilidade on-line possibilita a troca entre pessoas desconhecidas, mas com gostos em comum, portanto, "os produtos audiovisuais/televisivos possuem potencial agregador e motivador na construção de comunidades em torno de seus elementos por oferecem temáticas amplamente compartilhadas" (MATOS, 2017, p. 247).

Pontuamos, assim, que a maioria das pesquisas que conjugam a convergência midiática e a telenovela com vistas à recepção toma como referência a interatividade propiciada pelo emissor, seja em sites oficiais, blogs ou perfis nas redes sociais digitais que se vinculam à noção de uma estratégia transmidiática.

Tal tendência de estudos de recepção transmidiática é observada não só no Brasil, mas no mundo conforme a pesquisa de Evans (2011) citada anteriormente, e também em outros países. Na Espanha, por exemplo, Lacalle (2012) estudou o afastamento dos jovens dos programas de TV, em detrimento do uso de outras mídias, 
que é abordado num estudo de recepção sobre a ficção televisiva e a construção da identidade juvenil e de gênero. A visualização em streaming foi destaque como escolha mais popular, seguido dos sites das emissoras e outras páginas de fãs. Os seguidores mais fiéis optam pela internet para recuperar os episódios da TV, assim como recorrem aos sites à procura de notícias sobre estes assuntos. Além do que, quase metade dos entrevistados comentam frequentemente sobre os programas televisivos nos fóruns e redes sociais, onde se destaca a elevada participação das mulheres. A pesquisa de Voorveld e Van der Goot (2013) demonstra que os receptores assistem televisão realizando outras tarefas, “[...] temos alguns exemplos de participantes da pesquisa usando TV como cenário para desenvolver outras atividades em conjunto" (p. 4).

Conforme Jacks et al. (2014, p. 57, 276-277), é a diversidade dos enfoques dos estudos brasileiros que aponta o vigor desses estudos, pois as pesquisas brasileiras têm muito a contribuir junto à pesquisa latino-americana, sendo importantes neste cenário. A relevância se dá tanto em termos quantitativos, para que - no caso dos estudos de recepção e internet/convergência/transmídia - aumentem, quanto no esforço da qualificação das pesquisas realizadas, principalmente no que diz respeito à experimentação das metodologias e novos enfoques teóricos. É necessário enfrentar a complexa relação dos receptores com os meios de comunicação ainda mais com a emergência do fenômeno da convergência midiática. Ainda que em pouca escala, a autora destaca "um movimento metodológico que resulta da preocupação dos estudos com objetos e questões pautadas pelo contexto digital" (JACKS et al., 2017, 296).

Scolari (2015, p. 17) afirma que as pesquisas devem focar cada vez mais nos consumidores transmídia pois "o conteúdo produzido por fãs ocupa um papel central na expansão do universo ficcional". O autor salienta ainda que Evans (2008) tem demonstrado que nem todos os consumidores são transmidiáticos ou estão interessados em media surfing, ou seja, no ato de navegar pelas diferentes mídias e plataformas. Ao refletir sobre o consumo/recepção transmidiático o pesquisador provoca alguns questionamentos: "Seria, então, o consumo transmídia uma propriedade dos novos usuários? Uma característica de uma geração acostumada com o digital? Ou a prática limitada de um grupo, como os fãs de uma determinada marca?” (SCOLARI, 2015 p. 17-18). 
Apesar da comprovada necessidade do olhar dos pesquisadores se voltar cada vez mais para as experiências receptivas transmidiáticas e convergentes nas mais variadas telas e plataformas, é preciso que não se deixem de lado os estudos clássicos de recepção. Concepção essa endossada por Almeida (2018, p. 6042), em sua recente publicação:

\begin{abstract}
A tese também aponta um caminho para estudos sobre o público que consome televisão, em sua relação com o engajamento nas plataformas de redes sociais. Indica que, apesar de haver uma correlação entre números de audiência e engajamento, as ações transmídia potencializam a participação e engajamento de públicos de nicho. Desse modo, a atuação de fãs e espectadores participativos nas redes sociais online não representa completamente o público, nem deve substituir as pesquisas tradicionais de recepção.
\end{abstract}

Acreditamos, em conformidade com a autora, que os tradicionais estudos de recepção não podem ser deixados de lado pelos investigadores de comunicação. Porém, acrescentamos que o ideal seria que estes fossem combinados com as pesquisas de recepção transmidiática, confrontando o novo com o antigo, como fazemos nesta tese. Desta maneira, é possível termos uma maior clareza sobre o trânsito das audiências explorando de que forma e quais variáveis que podem determinar, no caso da ficção televisiva, a ainda assistência da TV e os usos e as apropriações carregadas de sentido que os receptores fazem das novas tecnologias. 


\section{Capítulo 4: A classe social como mediação estruturante}

Partilhamos da noção de que a classe social é responsável por articular as demais categorias constituidoras do sujeito, como, por exemplo, etnia e gênero. É responsável pela visão e compreensão de mundo do qual estes sujeitos fazem parte. Além do que a posição de classe é determinante para conformar as leituras, as interpretações, os usos e apropriações que estes sujeitos fazem da mídia, e, no caso da nossa pesquisa, da telenovela. Por isso, neste capítulo, discorremos sobre a importância do conceito de classe social ser problematizado em um estudo como o nosso, não só pelo fato da classe social ser essencial no que diz respeito à recepção da telenovela, mas também porque o Brasil é um país em que a desigualdade social é abissal. Ainda no capítulo, explicitamos a partir de quais autores entendemos a classe social bem como faremos uma discussão sobre a classe média no nosso país, tendo em vista que os receptores componentes da amostra da nossa pesquisa fazem parte de diferentes frações da classe média.

\section{1 A importância do conceito}

Partimos da premissa de que a relação estabelecida entre a mídia, a sociedade e a cultura não acontece de maneira análoga entre telespectadores de diferentes classes sociais. Isso porque consideramos a classe social à qual os atores pertencem uma mediação de nível estrutural (LOPES, BORELLI e RESENDE, 2002) para a constituição de suas representações e esta, relevante para a maneira como usam, interpretam, leem e se apropriam da mídia.

$\mathrm{Na}$ atualidade, a ênfase política e a preocupação com a ação social, principalmente o engajamento em teorias atentas às diferenças culturais não só dos estudos de recepção, mas de Comunicação parecem "estar se dissolvendo nos estudos atuais de Comunicação" (FIGARO; GROHMANN, 2013, p. 2). Principalmente no que diz respeito às questões que refletem sobre classe social, pois tem se notado um "esquecimento da classe social" (LOPES; BORELLI; RESENDE, 2002) nas pesquisas. Este esquecimento aconteceu pela equiparação da classe social com outras categorias como gênero, geração, etnia e nação como categorias de "relevância fundamental para a compreensão da sociedade contemporânea" (FONSECA, 2006, p. 13), não considerando que é a classe social que articula as demais categorias. Além disso, há 
uma outra questão, que diversas vezes o conceito não é utilizado com a profundidade necessária que demanda:

As pesquisas, em grande parte, naturalizam ou não discutem (um 'falar para não- falar') o conceito de classe e/ou não há uma relação mais explícita com uma perspectiva comunicacional e/ou não há uma 'vigilância epistemológica' entre as instâncias e fases da pesquisa. Os sentidos teóricos das classes, pois, são banalizados ou pouco aprofundados (GROHMANN, 2016, p. 94-95).

Para Medhurst (2000, p. 29), atualmente, entre as diversas identidades políticas discutidas e trabalhadas por investigadores politicamente motivados, a classe social ficou, em muitos sentidos, como a "identidade perdida". A autora afirma que, por outro lado, há forte investigação de outras questões relacionadas a outras formas de empoderamentos identitários, como os que tratam de feminismo, gays, lésbicas e negros. Munt (2000, p. 8) também aponta o apagamento dos estudos sobre classe em detrimento de outros assuntos: "Enquanto tem havido debate público nos últimos 20 anos sobre imagens positivas das mulheres, pessoas de cor, e gays e lésbicas, não tem havido um clamor equivalente para as representações da classe trabalhadora".

Mesmo com esse abandono das pesquisas que utilizam a categoria classe social, é possível afirmar que "a classe pode ter sido abolida retoricamente em muitos textos, mas uma quantidade impressionante de evidência empírica confirma que ela permanece como uma força essencial para modelar a maneira como vivemos hoje” (MURDOCK, 2009, p. 31). Um dos mais conhecidos estudos sobre a relevância da classe social nas pesquisas sobre a mídia é a obra The Nationwide Audience de autoria de David Morley (1980), um estudo de recepção canônico que explora as relações entre a posição de classe e os modos de interpretação de um programa informativo exibido na televisão inglesa, entre os anos de 1975 a 1979. Apesar das lacunas presentes, a pesquisa (KIM, 2004; RONSINI, 2011b) demonstra que a classe social é importante para conformar as diferentes leituras da mídia feitas pelas audiências, no entanto conclui que a classe não é a única determinante para conformar tais leituras.

Jacks, Sifuentes e Libardi (2017) concluem que, apesar de uma tímida retomada dos estudos de recepção e consumo midiático que refletem sobre classe social ao longo dos anos 2000, ainda existe uma lacuna a ser explorada, tendo em vista que, muitos 
estudos, conforme as autoras, ainda tratam a classe social apenas como uma categoria sociodemográfica e não como uma importante demarcadora de diferença.

Entendemos, portanto, que, numa pesquisa de Comunicação, é essencial considerarmos a classe social à qual os atores pertencem como relevante para a interpretação que fazem das mensagens midiáticas. A categoria permite que esses compreendam o mundo social do qual fazem parte, visto que a classe é considerada “[...] como uma parte intrínseca do seu 'ser social' - e, diria eu, como uma parte decisiva do seu "ser social"” (MILIBAND, 1999, p. 497, grifos do autor). A classe social, utilizada em pesquisas empíricas, é fundamental para desvelar a realidade do contexto social em que vivemos.

Além disso, é inconcebível pensar em não considerar a classe social em um país como o Brasil, onde a distância entre ricos e pobres é abissal, e onde temos "[...] uma das maiores concentrações de renda no mundo" (REGO e PINZANI, 2013, p. 148). Conforme o Relatório de Desenvolvimento Humano $(\mathrm{RDH})$ da Organização das Nações Unidas (ONU) de $2019^{46}$, o Brasil está em segundo lugar no mundo em má distribuição de renda entre sua população, atrás apenas do Catar. No nosso país, o $1 \%$ mais rico concentra 28,3 $\%$ da renda total do país, enquanto no Catar (o primeiro lugar no ranking), tal proporção é de 29\%. O que significa que quase um terço da renda está nas mãos daqueles mais ricos. Os dados ainda demonstram que os $10 \%$ mais ricos no Brasil concentram $41,9 \%$ da renda total Ainda segundo o $\mathrm{IBGE}^{47}$, o índice de desigualdade social (Índice de Gini), que tinha apresentado uma queda entre 2012 e 2015, passou a crescer no país, atingindo um valor de 0,545 (o índice varia entre 0 e 1, sendo 1 o valor que significa a máxima desigualdade) em 2018, maior apresentado desde 2012. Segue o gráfico do Índice de Gini:

\footnotetext{
${ }^{46}$ Disponível em: http://hdr.undp.org/sites/default/files/hdr2019.pdf Acesso em janeiro de 2020.

${ }^{47}$ Disponível em: https://biblioteca.ibge.gov.br/visualizacao/livros/liv 101678.pdf Acesso em janeiro de 2020.
} 


\section{Figura 12: Gráfico de Índice de Gini da distribuição do rendimento domiciliar per capita}

- Brasil: 2012-2018

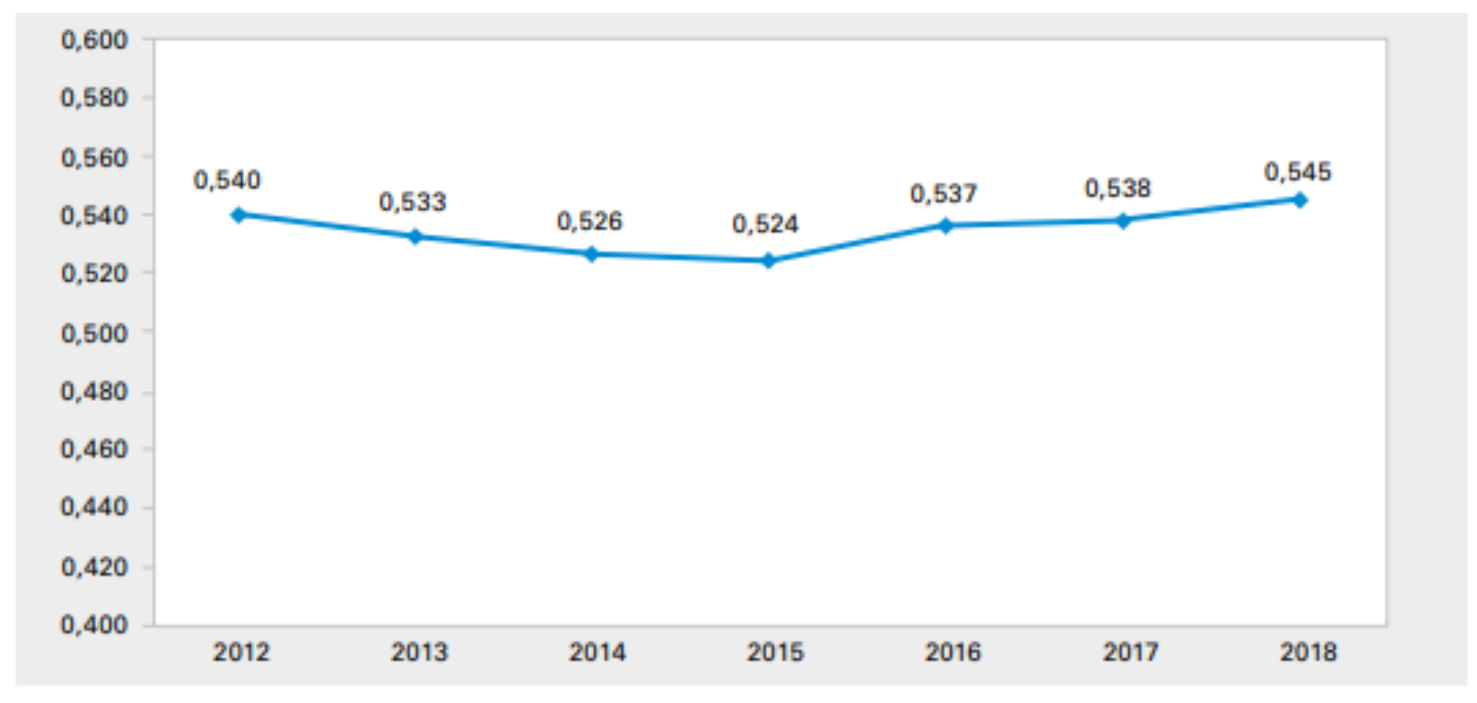

Fonte: IBGE - Pesquisa Nacional por Amostra de Domicílios Contínua 2012-2018.

Este abismo social causado pela desigualdade no Brasil é injusto, severo e comparado por Souza (2018, p. 140) à sociedade escravocrata:

Na realidade, o que acontece é a consolidação de um padrão de desigualdade abissal e cruel que reproduz com outros meios a antiga sociedade escravocrata. Nos dias de hoje, é óbvio, não se segregam desde o berço e em função da cor da pele aquelas pessoas destinadas ao cativeiro. Mas um tipo muito semelhante de segregação ocorre por meio de mecanismos invisíveis, como costumam ser os de classe.

Para Skeggs (2004), não refletir sobre a classe significa desconhecer a desigualdade social, ainda que saibamos que a classe social por si só não explica todos os aspectos que estabelecem tal disparidade. Porém, a categoria é fundamental para a compreensão desta desigualdade, porque

Ainda que as diversas dimensões da desigualdade social não possam ser reduzidas à desigualdade de classe, a premissa subjacente à análise marxista é a de que as relações de classe jogam um papel decisivo na moldagem das outras formas de desigualdade (SANTOS, 2002, p. 44). 
A classe social é determinante para a definição da organização social dos atores e para a estruturação das relações sociais, sendo esta uma das duas grandes doutrinas existentes no âmago da concepção de Marx (EAGLETON, 2012, p.17), um dos principais pensadores sobre o conceito e o qual também seguimos nesta tese. A classe é responsável também pela estruturação de outras categorias constituidoras dos sujeitos, como, por exemplo, o gênero e a etnia, pois “[...] o 'ser social' é na verdade um conjunto múltiplo e complexo de elementos, uma espécie de DNA social. No entanto é a classe que influi mais profundamente sobre todos os outros elementos" (MILIBAND, 1999, p. 498, grifo do autor). Logo, a classe estrutura os modos de vida e a visão de mundo:

\begin{abstract}
Não obstante sua existência objetiva como uma categoria empírica, e sua duradoura existência objetiva como experiência vivida, os efeitos da privação relativa não só afeta as chances de vida (quantificável), mas também estilos de vida, no modo como medimos e diferenciamos nosso status social (qualificável). As gradações desse status social informam e determinam nossa mobilidade no espaço social; elas afetam nossas práticas corporais, circunscrevem nossa realidade ideal, nosso senso de eu (MUNT, 2000, p. 3).
\end{abstract}

A organização social é permeada pela luta de classes sociais, e conforme Marx e Engels (2007 [1845- 46]), isso sempre perpassou a história da sociedade. Eagleton (2012, p. 20-21), afirma que isso não quer dizer que tudo o que acontece ou aconteceu em todas as sociedades seja uma questão de luta de classes, e sim, que esta é a base necessária para todas as outras questões, dando forma a diversos acontecimentos, instituições e vertentes de pensamento. Então declara:

Marx declara no Manifesto Comunista que "a história de toda a sociedade existente anteriormente é a história da luta de classes". Claro que não se deve interpretá-lo ao pé da letra. Se o fato de eu escovar os dentes na quarta-feira passada conta como parte da história, é difícil considerar tal ato como uma questão de luta de classes. Executar determinado arremesso no críquete ou ter obsessão patológica por pinguins não é fundamentalmente relevante para a luta de classes (EAGLETON, 2012, p. 30). 
De acordo com a tradição marxista, a noção de classe "trata-se de um conceito relacional, pois as classes são sempre definidas no âmbito das relações sociais, em particular nas relações das classes entre si” (SANTOS, 2002, p. 41). Em sua obra, Marx (2009 [ 1874]) desenvolve uma divisão quanto à identidade das classes, pois, para ele, existe a "classe em si", que "se dá pelo compartilhamento de condições objetivas ou mesma situação em relação à propriedade dos meios de produção"(GROHMANN, 2016, p. 101) e "classe para si”, que diz respeito à oposição estrutural da sociedade que tem como consequência "a auto-abolição do proletariado e das classes, não sendo somente uma organização política em situação de conflito" (Ibdem). Além de tudo, o conceito de classe social a partir de Marx não pode, de forma alguma, ser objetivado e sim compreendido sob a luz das mudanças que acontecem na sociedade e o que elas podem acarretar. Mas de fato, é o "lugar ocupado no modo capitalista de produção que constitui o ponto mais decisivo" (EAGLETON, 2012, p. 138) quando se investiga classe social sob esta perspectiva. Portanto:

[...] se é o lugar na produção o que define o pertencimento a uma classe em Marx, é, de fato, a dimensão de "luta" o que diferencia os marxismos de outras correntes. O conflito e o embate são centrais para a compreensão das classes. É entender o papel das classes sociais na transformação da sociedade (GROHMANN, 2016, p. 102, grifo do autor).

A origem da luta de classes é o processo de exploração baseado nas relações de produção pelos detentores dos meios de produção e propriedade e aqueles que oferecem a força de trabalho, a mão de obra. Por isso "classe é um conceito intrinsecamente político, já que requer relações de dominação" (SANTOS, 2002, p.42). Desta forma, a classe dominante visa, constantemente e desde sempre, manter e legitimar sua posição social:

[...] a classe dominante procura naturalmente, acima de qualquer outra coisa, defender, manter e fortalecer a ordem social, e o faz (com maior convicção e sinceridade) em nome do interesse nacional, da liberdade, da democracia ou do que quer que seja. Essa classe dominante é o que se pode adequadamente (e de fato literalmente) chamar de a principal classe conservadora da sociedade, o que obviamente não significa que outras classes não podem ser conservadoras ou não podem incluir muitas pessoas devotadas à causa conservadora (MILIBAND, 1999, p. 484). 
Mas tal dominação só acontece porque existe a hegemonia, entendida aqui com base em Gramsci (2002) em que os grupos subalternos sofrem constante investida dos grupos dominantes a fim de manter a subordinação. Ou nas palavras de Souza (2011, p. 408), a hegemonia é o

[...] consenso em benefício das classes dominantes e aceito como legítimo pelas classes inferiores que possibilita que, não na lei, mas na vida nossa de cada dia, algumas pessoas e classes estejam acima da lei e outras pessoas e classes sociais inteiras, abaixo dela.

A efetivação da classe se dá exatamente devido a esta relação entre dominadores e dominados, isto é, a partir das relações sociais estabelecidas por ambos. Salientamos também que o esforço para a manutenção da hegemonia acontece em diversos campos sociais:

Um amplo espectro de pessoas e instituições desempenha um papel nesse processo: os jornais e outras publicações, o rádio, a televisão, o cinema e o teatro, igrejas, partidos, associações e lobbies, escolas, intelectuais e outros 'administradores da aprovação' e, não menos importante, o Estado - em suma, tudo o que no sistema social dá uma contribuição, grande ou pequena, para o fortalecimento da ordem social e contenção ou derrota das forças 'contra hegemônicas' que um sistema de dominação e exploração necessariamente engendra (MILIBAND, 1999, p. 485).

A preservação da hegemonia depende ainda de um processo constante de distinção entre as classes sociais em função do aumento do poder aquisitivo e do acesso à informação das classes populares (PEREIRA, 2015). Então, as classes dominantes precisam, continuamente, através de formas práticas e simbólicas, legitimar seu lugar no espaço social e demarcar sua diferença, especialmente por meio de seu gosto e seu estilo de vida (BOURDIEU, 2007). Trataremos sobre a distinção entre as classes mais adiante neste capítulo.

Acreditamos, assim, que, para uma análise que contemple a complexidade das questões de classe social, devam ser levados em consideração não apenas os fatores econômicos, mas também os culturais apesar de que entendemos que o estilo de vida dos atores pode ser condicionado, majoritariamente, pelas condições econômicas em que vivem. Por esta razão, pactuamos da proposta de Santos (2002), que defende a investigação das questões de classe social por meio de uma análise da posição de classe, 
podendo esta ser detectada pela ocupação profissional dos atores. Ademais, "a classe dominante e a classe trabalhadora representam respectivamente o vértice e a base da pirâmide característicos da estrutura social das sociedades capitalistas avançadas" (MILIBAND, 1999, p. 482).

É pertinente destacar que, nos últimos anos, o aumento do poder de compra das classes populares nos governos PT de Lula (2003-2006 e 2007 - 2011) e Dilma (20112014- 2016) fez com que, equivocadamente, fossem mascaradas as enormes distâncias entre as classes sociais no Brasil (SOUZA, 2012). Acrescentamos ainda que as classes sociais não são estáticas, tampouco homogêneas (MILIBAND, 1999, p. 479) e a mobilidade existente entre as frações de classe são mais horizontais do que de fato verticais, havendo, raramente, uma mudança de uma classe para outra:

[...] as pessoas localizadas em diferentes pontos da pirâmide não são totalmente imóveis: há um certo movimento, muito limitado, para cima, e um certo movimento para baixo, e os diferentes níveis da pirâmide não são separados por linhas divisórias rígidas. Mas nem a mobilidade social nem as fronteiras indistintas mudam o fato de que a pirâmide é uma dura, sólida realidade e de que as diferenças ente a classe situada nos níveis superiores da pirâmide e as classes situadas nos níveis inferiores são de fato muito grandes em termos de riqueza, renda, poder, responsabilidade, estilo e qualidade de vida e tudo o mais que compõe a textura da existência (MILIBAND, 1999, p. 483).

Desta forma, corroboramos com a ideia de que a classe social deve ser observada em um estudo de comunicação, pois tais pesquisas

[...] podem contribuir, ao considerarem as classes sociais como categoria de análise, tendo-as na dimensão de sua complexidade, lugar social de produção de sentido, de pontos de vista. Nunca se distanciando da compreensão de que as classes se definem por oposição e que redundam em relações de poder. A classe dominante, assim o é porque suas ideias dominam. Fato que não invalida a existência de outras ideias, muitas vezes, ainda não organizadas como ideias contra hegemônicas (FIGARO e GROHMANN, 2013, p. 15).

Todavia, de acordo com o nosso entendimento, há necessidade de uma atualização do uso da classe social, especialmente quanto a suas bases ortodoxas, pois existem outras categorias que também são responsáveis pela constituição social dos sujeitos, sendo essas esferas culturais que podem ser afetadas pelos aspectos econômicos que incidem nas práticas de representações dos atores, como a etnia, o gênero, a geração, o 
grau de instrução escolar, etc. (PEREIRA, 2015). Assim, utilizamos a teoria de classe social cunhada por Pierre Bourdieu, uma vez que compreende o conceito para além dos aspectos econômicos, mas a partir da articulação de diversos capitais. Para o sociólogo, estes capitais também são responsáveis pela composição de uma cultura de classe, e, portanto, essencial para a formação social dos atores.

\subsection{A classe social a partir de Pierre Bourdieu}

O filósofo francês Pierre Bourdieu tornou-se um sociólogo de importância mundial e é o segundo intelectual francês mais citado no mundo. Ele desenvolveu uma ciência geral das práticas sociais e da compreensão do mundo social a partir de três principais conceitos elaborados pelo próprio: campo, capital e habitus (LOYOLA, 2002; DUARTE-PLON, 2012). Umas das suas obras mais emblemáticas é A Distinção crítica social do julgamento publicada pela primeira vez em 1979 e considerada pela Associação Internacional de Sociologia "um dos dez trabalhos mais importantes de sociologia produzidos no século XX” (LOYOLA, 2002, p. 89). No livro, o autor elaborou uma teoria geral das classes sociais por meio de uma detalhada descrição das práticas ao "consumo cultural e aos gostos" (LOYOLA, 2002, p. 89), sendo estes últimos manifestados através das práticas de consumo, assim, produtos de condicionamentos associados a uma classe ou fração de classe. Sobre a distinção de classe e gosto, iremos trabalhar no tópico 4.2.1 deste capítulo.

Olhar para as questões de classe social sob a luz de Pierre Bourdieu significa compreendê-las para além dos aspectos econômicos e considerar também as práticas culturais, os aspectos simbólicos e materiais que envolvem a constituição e a identificação social dos atores. Logo, a classe social é importante para a compreensão do mundo em que se vive e é caracterizada por

[...] conjuntos de agentes que ocupam posições semelhantes e que, colocados em condições semelhantes e sujeitos a condicionamentos semelhantes, têm, com toda a probabilidade, atitudes e interesses semelhantes, logo, práticas e tomadas de posição semelhantes (BOURDIEU, 2010, p. 136).

Em conformidade com Bourdieu, consideramos que "a posição ocupada por uma classe no espaço social é definida pela posição que ocupa nos diferentes campos - 
econômico, social e cultural" (RONSINI, 2007, p. 22). O campo espaço social é estruturado e multidimensional, e as diferentes posições ocupadas pelos agentes ou por um grupo, e por conseguinte, as diferentes classes sociais são definidas de acordo com o volume e a composição de um ou mais capitais incorporados ou adquiridos ao longo da trajetória social desses agentes. Já o espaço social é a representação multidimensional, abstrata e relacional da estrutura da sociedade de acordo com volume e a estrutura de capital (PEREIRA, 2015, p. 53). Da mesma forma que Marx, Bourdieu também acredita que, quanto mais acúmulo de capital, maior é o poder que um agente ou instituição tem na sociedade capitalista. Mas, para o francês são necessárias ainda outras formas de capital para assegurar o acesso privilegiado a todos os bens e recursos. Deste modo, os capitais definidos pelo Bourdieu são

o capital econômico, caracterizado como conjunto de recursos patrimoniais como renda, terras, bens imobiliários, etc.; o capital cultural, que é a soma de qualificações intelectuais que um ator possui, seja esse advindo da família ou da escola e, "diferentemente de Bourdieu, que não leva em conta a mídia como capital cultural, pensamos que os meios de comunicação devem ser tomados como instâncias que complementam a educação formal escolar e a educação familiar" (RONSINI, 2012, p. 32); o capital social, ou seja, os contatos, as relações socialmente úteis feitas ao longo da trajetória social e profissional dos atores e o capital simbólico, aquele ligado à honra, ao reconhecimento e ao prestígio, legitimando todos os outros capitais citados (PEREIRA, 2015, p. 53).

O capital econômico, então, é a posse de riquezas financeiras que um ator social possui, seja por meio de propriedades, renda ou salários, e, na maioria das vezes, é transmitido por meio de herança familiar. Skeggs (1997) ressalta que as pessoas nascem com uma determinada quantia de capital econômico e que, quanto mais estas têm tal capital, maior é a facilidade de acumular mais e mais. Bourdieu reconhece que o capital econômico é decisivo para assegurar as vantagens permanentemente em disputa (SOUZA, 2013).

Para Souza (2013), a definição de capital cultural é uma das maiores descobertas de Bourdieu para a ciência social crítica. Acrescentamos que o capital cultural existe em três formas: no estado incorporado como disposições duradouras do corpo e da mente (como por exemplo no domínio de linguagem e facilidade de expressão em público); no estado objetivado ou seja, como bem cultural na posse de livros, quadros, dicionários, 
instrumentos, por exemplo; e no estado institucionalizado, que significa o que é socialmente sancionado por instituições sendo resultado de qualificações educacionais, como por exemplo diplomas e títulos escolares. Skeegs (1997) afirma que este capital não existe de forma isolada e é dependente dos outros capitais, tendo forte relação com o capital econômico. Porém, é necessário relativizar tal ligação destes dois capitais, pois dois atores sociais com o mesmo capital econômico podem ter capitais culturais diferentes, por isso que existem diferentes frações de uma mesma classe social. Conforme explanado claramente por Souza (2011b, p. 1):

Tomemos um professor universitário iniciante que ganhe $\mathrm{R} \$ 6$ mil. Tomemos agora um trabalhador qualificado que monitora os robôs da Fiat, em Minas Gerais, que também ganhe algo em torno de R\$ 6 mil mensais. Todas as escolhas dessas pessoas vão ser, com muita probabilidade, distintas, desde a mulher que se escolhe, os amigos, o tempo de lazer, as roupas que se compram, o padrão de consumo, os livros que se leem etc. Quando muito, essas pessoas vão poder conversar sobre futebol entre si. Qual o sentido de dizer que essas pessoas são da mesma classe porque ganham um salário semelhante? Ajuda a nossa compreensão de alguma delas estabelecer esse tipo de relação? O que esta concepção dominante sobre as classes em todas as ciências hegemônicas e em toda a esfera pública dos jornais e das TVs permite é "esquecer" e relegar às sombras o principal: que as classes sociais são formadas por "culturas de classe" muito diferentes entre si. Não existe "o" brasileiro, nem "a" mulher. É o pertencimento de classe que permite qualificar e compreender as pessoas na sua diferença.

Existe uma dinâmica constante e móvel dentro de cada classe e também entre as classes diferentes que é resultado dos conflitos e da reconversão dos capitais. Isto permite a análise dos campos e subcampos de uma maneira diacrônica, assim as classes são compostas em frações que podem variar de acordo com a relação entre todos os capitais e a posição que eles ocupam na vida dos agentes, podendo ser estáveis, ascendentes ou descendentes (BOURDIEU, 2007).

Sobre o capital social, complementamos que ele pode ser mobilizado pelos agentes ou grupos ao longo da sua trajetória profissional e social, conferindo maior ou menor espessura social em função da qualidade e também da quantidade das conexões estabelecidas. Consequentemente, é resultado das estratégias de investimento social realizadas pelos sujeitos a fim de manter ou criar ligações capazes de gerarem tanto 
lucros materiais quanto simbólicos, pois Barros Filho e Martino (2003) salientam que este pode ser denso e revertido em outros capitais.

O capital simbólico é resultado da mudança de uma relação de força em relação de sentido, ou seja, uma lógica da economia de bens simbólicos. Este capital diz respeito aos métodos usados pelos agentes com a finalidade de reprodução, reconversão ou acumulação das diferentes espécies de capitais para manter ou obter melhor posição no espaço social. É uma "operação fundamental na alquimia social" (BOURDIEU, 2013, p. 114), tendo uma de suas manifestações no estilo de vida em que um ator tem.

Isto posto, a classe social:

[...] não é definida por uma propriedade (mesmo que se tratasse da mais determinante, tal como o volume e a estrutura do capital), nem por uma soma de propriedades (sexo, idade, origem social ou étnica por exemplo, parcela de branco e de negros, de indígenas e de imigrantes, etc.-, remunerações, nível de instrução, etc.), tampouco por uma cadeia de propriedades, todas elas ordenadas a partir de uma propriedade fundamental - a posição das relações de produção-, em uma relação de causa e efeito, de condicionante a condicionado, mas pela estrutura das relações entre todas as propriedades pertinentes que confere seu valor próprio a cada uma delas e aos efeitos que ela exerce sobre as práticas (BOURDIEU, 2007, p. 101).

O volume e a estrutura de todos os capitais "conferem sua forma e seu valor específicos às determinações que os outros fatores - idade, sexo, residência, etc. impõem às práticas" (BOURDIEU, 2007, p. 102), mas é a maneira como esses capitais estão compostos e a quantidade deles que são relevantes para instituir essas determinações. Tais práticas associadas à articulação da classe com as demais categorias constitutivas de um agente são sempre consequência de um habitus. Este é definido como um sistema de disposições duráveis e transponíveis, inconsciente, podendo ainda gerar práticas em esferas alheias àquelas de origem, adquiridas pelo indivíduo ao longo do seu processo de socialização, que elabora e organiza as práticas e as representações de indivíduos e grupos (BOURDIEU, 2007, p. 162-164). O habitus é transponível porque não é fixo e nem irredutível, pode ser reformulado e revertido, por isso é "produto da história, é um sistema de disposições aberto, permanentemente afrontado a experiências novas e permanentemente afetado por elas. É durável, mas não imutável” (BOURDIEU in LOYOLA, 2002, p. 83). Barros e Martino (2003) afirmam que, para formular este conceito de habitus, Bourdieu utilizou como fonte Wittgenstein, que 
pensava em hábito a partir de Aristóletes. Para o filósofo grego, o hábito é uma disposição humana que define como o sujeito age (sendo a ação executada intencionalmente e quando repetida demonstra o comportamento desta pessoa), constituindo-o e qualificando-o para a vida em sociedade (ARISTÓTELES, 2009). Além do mais, segundo o pensador, a educação seria capaz de programar e organizar os hábitos futuros de um agente.

Segundo Souza (2010), o habitus é uma herança imaterial deixada por indivíduos da mesma família de uma determinada classe social:

[...] o habitus compartilhado confere sentido à noção de "habitus de classe" por associar objetivamente, para além de qualquer acordo consciente, pessoas em uma mesma situação de classe. Assim, classe deixa de ser percebida a partir de propriedades ou de coleções de propriedades para ser definida como fundamento de "práticas sociais" similares, que permitem estratégias comuns e consequências compartilhadas mesmo na ausência de acordos conscientes e refletidos. $\mathrm{O}$ pertencimento à classe explica por que os indivíduos não se movem de modo arbitrário no espaço social (SOUZA, 2012, p. 5758 , grifos do autor).

Então, o habitus é o princípio básico e organizador social que predispõe o desenvolvimento dos gostos e dos estilos de vida dos atores, tornando-os, assim, pertencentes a uma classe social. O conjunto de práticas geradas pelo habitus é o estilo de vida, ou seja, o comportamento, as preferências, as ações e os usos materiais através do consumo que os atores de determinada classe social fazem. $\mathrm{O}$ estilo de vida adotado pelas pessoas, majoritariamente, é balizado pelo capital econômico, porém uma mesma fração de classe pode ter inúmeros estilos de vida, mesmo assim, esse possui certa uniformidade.

\subsubsection{A distinção entre as classes sociais}

O habitus é o gerador da distinção de classe social, "pois é a diferença entre o habitus de classe, entre os estilos de vida e gostos que estão na base desta distinção entre as classes e que podem ser observados a partir das práticas culturais, simbólicas e 
materiais dos sujeitos" (PEREIRA, 2015, p. 55). A classe atravessa e articula todas as demais categorias constituidoras de um sujeito e, assim, determina suas práticas e o seu gosto.

Conforme Bourdieu (2007), o gosto é um marcador de classe, um classificador que distingue e é caracterizado pelas preferências manifestadas que "são a afirmação de uma diferença inevitável” (BOURDIEU, 2007, p. 56). É responsável pelo posicionamento e identificação social dos atores, e os diferentes gostos são constituídos por capitais majoritariamente dissonantes

O gosto, propensão e aptidão para a apropriação - material e/ou simbólica - de determinada classe de objetos ou de práticas classificadas e classificantes é a fórmula geradora que se encontra na origem do estilo de vida, conjunto unitário de preferências distintivas que exprimem, na lógica específica de cada um dos subespaços simbólicos - mobiliário, vestuário, linguagem ou hexis corporal - a mesma intenção expressiva (BOURDIEU, 2007, p. 165, grifo do autor).

O gosto é aversão e intolerância visceral às preferências dos outros, sendo capaz de aproximar mas também de afastar aqueles que experimentam os bens culturais. Esta distinção acontece a partir da luta pelo "gosto legítimo", ou seja, o gosto pelas obras legítimas, algo que vem da alma, e normalmente associado às classes dominantes em oposição ao "gosto popular", aquele que é vulgar, vindo do corpo, relacionado às classes populares. Portanto, “a intolerância estética exerce violências terríveis. A aversão pelos estilos de vida diferentes é, sem dúvida, umas das mais fortes barreiras entre as classes" (BOURDIEU,2007, p. 57).

É por meio da distinção entre as classes sociais que a classe dominante exerce a violência simbólica (BOURDIEU, 2007) sobre as classes posicionadas inferiores a ela no espaço social. Isto acontece mesmo que esta violência não seja perceptível enquanto tal, nem mesmo pelas próprias vítimas envolvidas nessa luta de classes. Por conseguinte, "a violência simbólica é aquela que não parece violência, que se vende como convencimento, mas que, na verdade, retira a possibilidade de reflexão, e portanto, de qualquer autonomia da vontade" (SOUZA, 2018, p. 113), pois é esta luta que está por trás desse princípio de reprodução social:

As lutas, cujo pretexto consiste em tudo o que, no mundo social, se refere à crença, ao crédito e ao descrédito, à percepção e à apreciação, 
ao conhecimento e ao reconhecimento - nome, reputação, prestígio, honra, glória e autoridade -, em tudo o que torna o poder simbólico em poder reconhecido, dizem respeito forçosamente aos detentores 'distintos' e aos pretendentes 'pretensiosos' (BOURDIEU, 2007, p. 235 , grifos do autor).

Ortiz (1983) afirma que a luta de classes é velada e envolve relações de poder e de dominação, desenvolvendo-se "pelo controle de capital simbólico, permitindo que as classes dominantes possam impor arbitrariamente os critérios de classificação ou de desclassificação social que legitimam a dominação social” (PEREIRA, 2015, p. 55). Entra em jogo então a luta pelo pertencimento de classe:

é o pertencimento de classe que nos esclarece acerca do acesso positiva ou negativamente privilegiado a qualquer tipo - material ou ideal - de recurso social escasso; e, 2) dado que a sociedade moderna se legitima na medida em que "aparece" como justa e igualitária, são as justificativas para a desigualdade efetiva entre as classes que formam o núcleo da legitimação social e política que permitem que a sociedade moderna possa ser aceita como justa também pelos injustiçados e humilhados por ela (SOUZA, 2013, p. 1).

Esta disputa por legitimação acontece baseada na invisibilidade e opacidade da estrutura de tal ordem social (OLIVEIRA-CRUZ, 2016). Além do mais, o acesso privilegiado proporcionado por uma posição de classe não é limitado apenas aos bens materiais, mas também aos imateriais, como "respeito, autoestima, reconhecimento, 'cultura', prestígio, 'charme"” (SOUZA, 2013, p.1, grifos do autor). O autor acrescenta que são justamente tais recursos que proporcionam empregos com bons salários e prestígios bem como as relações de amizade e amorosas entre pessoas de uma mesma classe social:

[...] quem consome cachaça ou cerveja barata, come bife gorduroso no almoço, veste camiseta regata e bermuda e fala com erros de português, sem demonstrar o menor senso estético, é percebido como sendo 'menos gente' por todos das classes privilegiadas. Isso não exclui o contato social, quando, por exemplo, entram nas casas de classe média para fazer faxina ou consertar algo. Mas com essa gente não se travam amizades reais, não se casam, não se fazem negócios [...] É assim que o pertencimento de classe efetivamente atua em nosso cotidiano (SOUZA, 2018, p. 65).

Apesar dessa dominação ser predominantemente ocasionada pelo capital 
econômico, ele por si só não basta para manifestar a manutenção da posição ocupada no espaço social. O cultural deve ser relacionado e levado em consideração nesse jogo:

Pudemos então afirmar que a dominação essencial de uma determinada classe na sociedade mantém-se não somente, ainda que certamente se for necessário, através do poder, e não somente, ainda que certamente se for necessário, através do propriedade. Ela se mantém também, inevitavelmente, pela cultura do vivido: aquela saturação do hábito, da experiência, dos modos de ver, sendo continuamente renovada em todos as etapas da vida, desde a infância, sob pressões definidas e no interior de significados definidos, de tal forma que o que as pessoas vêm a pensar e a sentir é, em larga medida, uma reprodução de uma ordem social profundamente arraigada a que as pessoas podem até pensar que de algum modo se opõem, e a que, muitos vezes se opõem de fato (WILLIAMS apud CEVASCO, 2001, p. 127).

É importante ressaltar, então, que os valores dominantes não são fixos e muito menos únicos, visto que são tensionados com os valores dos oprimidos (mesmo quando a opressão não é de fato combatida, e sim consentida). Entramos aqui, mais uma vez, no conceito de hegemonia de Gramsci, uma vez que

[...] o processo hegemônico de constituição da vida social funciona por sua atividade e adaptação contínua. Isso significa reconhecer (e, principalmente, acomodar) significados, valores, opiniões e práticas alternativas e opositoras na estruturação da cultura efetiva dominante (OLIVEIRA-CRUZ, 2016, p. 26).

Assim sendo, a luta de classes deve ser analisada a partir dos tensionamentos que perpassam o processo social como um todo, ou seja, perceber a relação entre subordinados e dominantes "em suas formas como consciência prática, como efeito de saturação de todo o processo de vida" (WILLIAMS, 1979, p. 111) que engloba as atividades econômicas, sociais, políticas e até mesmo a construção da identidade dos atores sociais.

Porém, Souza (2018, p. 145) afirma que no Brasil a luta de classes não acontece em sua forma real devido à enorme desigualdade social existente no país:

No Brasil, enfim, nunca tivemos uma luta de classes de verdade, na qual os interesses das classes populares tenham se feito valer como 
direito. O que sempre tivemos aqui foi uma cruel e covarde opressão de classe, na qual qualquer tentativa de diminuir, por pouco que fosse, a abissal distância social redundou em golpes de Estado e em estados de exceção.

Portanto, as classes sociais se relacionam e mantêm sua posição com base em um conflito de interesses que deve ser considerado porque não perceber como este conflito acontece e nem suas dinâmicas é também ser conveniente com ele (CEVASCO, 2001).

\subsection{As classes médias no Brasil: sobre quem estamos falando?}

A discussão acerca da classe média no país é essencial porque a amostra da nossa pesquisa empírica, conforme já apontamos, é composta por receptores de duas frações da classe média. Além de situar contextualmente a nossa amostra, é de suma importância problematizarmos algumas questões que envolvem essa classe social pelo fato de ter sido amplamente comentada em diferentes esferas, nos últimos anos, no Brasil.

Neri (2008, 2010, 2012), diretor da Fundação Getúlio Vargas Social, concebe a classe média como um estrato que ocupa a posição intermediária na sociedade, denominando-a de classe $\mathrm{C}^{48}$. O índice é calculado a partir do seu potencial de consumo, ou seja, no "impacto de bens sobre medidas de acesso a bens duráveis e seu respectivo número (TV, rádio, lava-roupa, geladeira e freezer, videocassete ou DVD), banheiros, empregada doméstica, e nível de instrução do chefe de família" (NERI, 2008, p. 23-24) com base nos dados do IBGE. Para o economista, esta classe é composta por familias com renda mensal de $\mathrm{R} \$ 1.892,65$ a $\mathrm{R} \$ 8.159,37$, e o número de pessoas pertencentes a esta classe diminuiu de 2017 para 2018, passando de 56,3\% para 55,3\% e, em 2018, ano do último levantamento, totalizavam 115,3 milhões de pessoas. ${ }^{49}$ Estes números estão ilustrados nos gráficos abaixo:

\footnotetext{
${ }^{48}$ A estratificação das classes sociais em A, B, C, D e E faz parte das diretrizes estabelecidas pelo Critério Brasil com o parâmetro desenvolvido pela ABEP (Associação Brasileira de Empresas de Pesquisa) e tem como base a Pesquisa de Orçamento Familiar (POF) do IBGE. A classificação é feita a partir da posse de bens e da renda familiar. Disponível em: www.abep.org Acesso em agosto de 2019.

${ }^{49}$ Disponível em: https://cps.fgv.br/home e https://valor.globo.com/brasil/noticia/2019/10/29/classes -a-eb-voltam-a-crescer-e-atingem-144-da-populacao.ghtml Acesso em fevereiro de 2020.
} 
Figura 13: Evolução das classes em porcentagem da população

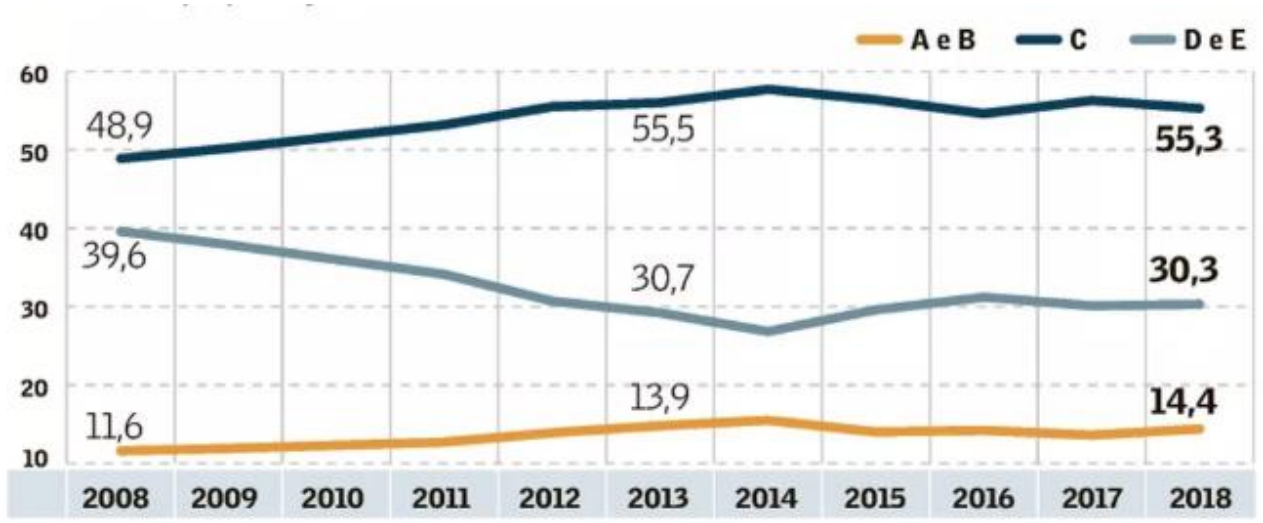

Fonte: Valor Econômico

Figura 14: Evolução das classes em milhões de pessoas

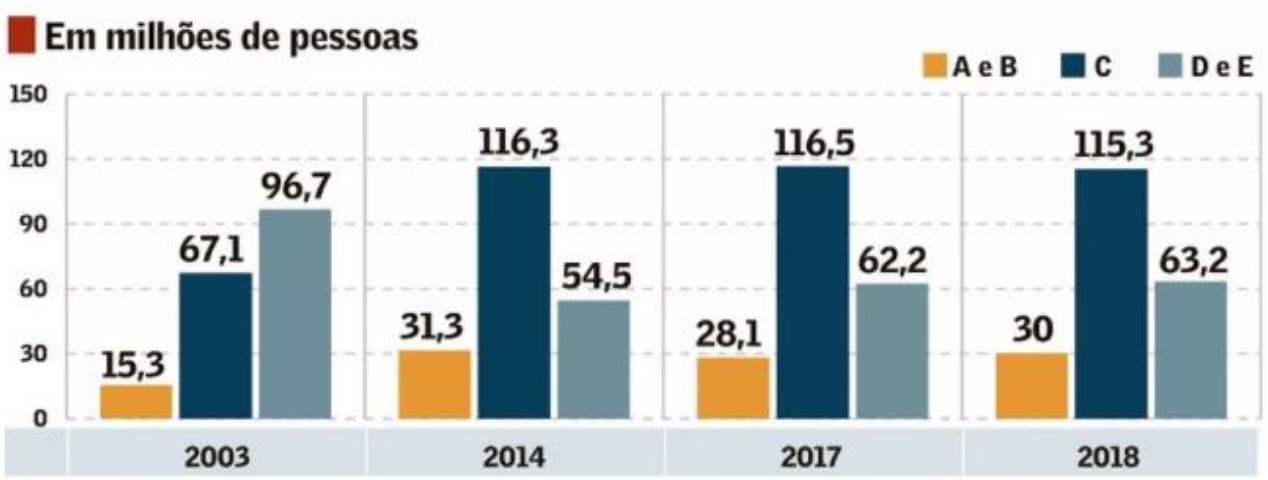

Linhas de cortes

\begin{tabular}{|c|c|c|}
\hline Classe A e B & Classe C & Classe D e E \\
\hline $.159,37$ & De $\mathrm{R} \$ 1.892,65$ até $\mathrm{R} \$ 8.159,37$ & Até $\mathrm{R} \$ 1.892,65$ \\
\hline
\end{tabular}

Fonte: Valor Econômico

Reconhecemos que os dados estatísticos usados por Neri são importantes para fins de operacionalização empírica de uma investigação que leva em conta a classe social, assim como a nossa. Porém, pactuamos da ideia de Souza (2013) de que dados como este são ricos porque fornecem informações significativas para uma análise da estrutura social do país. Porém é preciso dar a esses dados uma reflexão teórica densa para compreender a complexidade da estrutura social brasileira. Isto quer dizer que os números apresentados por Neri atestam o poder de consumo da classe média e focam apenas na renda, ou seja, no capital econômico, mas o economista 
desconsidera o engendramento dos demais capitais (social e cultural) na conformação do habitus de classe desses sujeitos e os reflexos desse conjunto de modo mais contextual - na manutenção da ordem social e da desigualdade (OLIVEIRA-CRUZ, 2016, p. 29).

Portanto, em nossa concepção, a definição de classe média não deve estar atrelada apenas à renda das famílias ou à quantidade de bens que elas possuem, mas também à sua visão de mundo atrelada às suas práticas. Por isso, consideramos a cultura como essencial para refletirmos sobre classe. Para Pochmann (CHAUÍ, 2014, p. 10, grifos da autora):

a ausência de uma análise das classes sociais em sua determinação concreta ou segundo as condições reais de sua base material redunda em 'um voluntarismo teórico inconsciente com a realidade, salvo interesses específicos ou projetos políticos de redução do papel do Estado'.

A classe média é complexa justamente por ocupar uma posição intermediária no espaço social, pois

[...] a classe média não é unívoca, e sim heterogênea, pois sua realidade e seu sentido se modificam quando acompanhamos as mudanças do e no modo de produção capitalista desde a fase do capitalismo da livre concorrência até a do capitalismo monopolista transnacional contemporâneo (CHAUÍ, 2014, p. 10).

Por isso que, trazemos aqui as percepções que mais condizem com a perspectiva adotada nesta tese, que, como já tratamos, versa sobre o paradigma de classe social a partir de Pierre Bourdieu e dos estudos sobre a cultura. Desta forma, a classe média é aquela que detém os capitais cultural, econômico e social em um volume expressivo que possa possibilitar a reprodução dessa classe ao longo de outras gerações familiares. A título de operacionalizar as análises empíricas utilizando os dados estatísticos, pode-se dizer que, fazem parte da classe média todas as pessoas que já conquistaram um nível de renda confortável e, mesmo que não possam usufruir de um padrão de vida da classe alta, têm acesso a um elevado patamar de habitação, lazer e consumo. Significa que seu padrão de consumo e comportamento é distinto (MILLS, 1951; BOURDIEU, 2007), sendo esta distinção constantemente 
reivindicada com a intenção de demarcar a diferença perante as camadas inferiores do espaço social. O interessante, então, é se aproximar do status das camadas superiores e afastar-se das inferiores.

Souza $(2006,2010,2011,2012$, 2013) relata que a principal característica da classe média no Brasil é a posse de capital cultural diferenciado, em que o acúmulo deste inicia na infância. Acrescenta que o tempo dedicado à educação e todas as atividades culturais é fundamental para o acúmulo deste capital cultural. Este tempo de dedicação tem um custo que, para o sociólogo, só as classes mais altas podem arcar por possuírem recursos econômicos. Assim, os filhos das classes média e alta usufruem desse tempo exclusivo ao estudo, e os das classes baixas devem abrir mão dele para trabalhar e ajudar na complementação da renda familiar. Este ciclo reproduz e eterniza o privilégio e a relação de exploração das classes altas perante as baixas, pois os filhos dos que possuem mais dinheiro e bens têm mais chances de melhores posições no mercado de trabalho, reproduzindo, mantendo e, muitas vezes, ascendendo de classe da qual fazem parte:

[...] uma família de classe média, que tem menos capital econômico que a classe alta, só pode assegurar a reprodução de seus privilégios se a família possui algum capital econômico para comprar o tempo livre dos filhos, que não precisam trabalhar cedo como os filhos das classes populares, para o estudo de línguas ou de capital cultural técnico ou literário mais sofisticado. Ao mesmo tempo, a competição social não começa na escola. Para que possamos ter tanto o desejo quanto a capacidade de absorção de conhecimento raro e sofisticado, é necessário ter tido, em casa, na socialização com os pais ou quem ocupe esse lugar, o estímulo afetivo - afinal, nos tornamos seres humanos imitando a quem amamos - para, por exemplo, a concentração nos estudos, ou a percepção da vida como formação contínua onde o que se quer ser no futuro é mais importante que o que se é no presente (SOUZA, 2013, p. 58-59).

Owensby (2004 apud GUERRA et al., 2006) afirma que uma especificidade típica da classe média é que esta tem os valores conservadores nas esferas moral e política. Para o autor, "na classe média, salienta-se a preservação de valores morais e religiosos; a busca pela supressão de um espírito de cooperação e vontade de ascender da classe operária; e o apoio político à conjuntura vigente" (SIFUENTES, 2014, p. 43). A classe média ainda é caracterizada por ser composta, especialmente, 
de administradores e profissionais que, além de possuírem nível de superior de escolaridade e deterem renda elevada, são majoritariamente brancos (SCALON e SALATA, 2012). Souza (2018, p. 130) enfatiza que a alta classe média é como se fosse um prolongamento da elite de proprietários:

[...] Nela conflui a defesa dos privilégios que mantém a dominação social possível e invisível. Enquanto aos proprietários interessa reproduzir e aumentar a riqueza, à alta classe média interessa manter sua posição privilegiada na gerência, supervisão e justificação dos interesses da propriedade em todas as suas dimensões.

O autor também compara duas frações da classe média, justamente as frações que fazem parte da amostra desta pesquisa e que será mais detalhada no capítulo seguinte. São elas: a classe média alta e a classe média baixa. Souza (2018, p. 131) então declara:

Se a alta classe média reverbera o discurso liberal-elitista, ao mesmo tempo pró-mercado e anti-industrial, a massa da classe média é mais complexa e contraditória, pois, espremida entre as classes altas e as classes populares, vai refletir as angústias dessa posição ambígua.

É justamente a nossa concepção sobre o que é a classe média baixa no Brasil que iremos discutir no subtópico seguinte.

\subsubsection{Nova classe média? Não, nova classe trabalhadora}

O termo "nova classe média" tem sido utilizado no Brasil indiscriminadamente desde 2008, quando a Fundação Getúlio Vargas divulgou uma pesquisa que demonstrava o aumento do poder aquisitivo da "classe C" e a migração de mais de 30 milhões de pessoas das classes $\mathrm{D}$ e $\mathrm{E}$ para a $\mathrm{C}$ naqueles últimos dez anos ${ }^{50}$. Conforme Neri (2010), o coordenador da investigação, isto foi ocasionado pelo aumento de renda e acesso maior a crédito, resultado de políticas públicas e da estabilização da economia. A "nova classe média", assim denominada e difundida pela FGV, pôde então comprar bens como, por exemplo, carro, computador e casa. Como já mencionamos

\footnotetext{
${ }^{50}$ Disponível em: http://www.cps.fgv.br/ibrecps/M3/M3_TextoFinal.pdf Acesso em agosto de 2019.
} 
anteriormente neste capítulo, a FGV considera a renda familiar como determinante para realizar a estratificação social no país.

No mesmo dia da divulgação da pesquisa da FGV, o Ipea (Instituto de Pesquisa Econômica Aplicada), presidido na época pelo economista Marcio Pochamann, também apresentou os resultados de um estudo com dados similares, mas enfatizando a diminuição do número de pessoas pobres no Brasil e não a existência de uma "nova classe média" ${ }^{, 51}$. Mas os resultados da investigação da FGV foram mais divulgados pela mídia nos mais diversos veículos. Esta visibilidade midiática dada à expressão (SIFUENTES, 2014; OLIVEIRA-CRUZ, 2016; GROHMANN, 2016) tornou o discurso otimista da existência de uma "nova classe média" senso comum. Ademais, tal “'explosão de classes midiatizadas' capazes de dotar de sentido e significado as interações e as práticas de consumo dos sujeitos" (GROHMANN, 2014, p. 152, grifo do autor) teve como consequência a "mercantilização da expressão" (OLIVERIA-CRUZ, 2016, p. 31). Isto se deve ao fato de que as empresas aproveitam a oportunidade do poder de consumo desta camada para lucrar. Porém, (GROHMANN, 2014, p.156, grifos do autor) analisa que, na maioria dos textos jornalísticos sobre a "nova classe média", “o ethos da 'nova classe média' é diferente do ethos imaginado do receptor", porque as reportagens visam mostrar, desvendar quem são as pessoas que compõem essa classe, quais seus hábitos e o que consomem. Afinal, "a esfera do consumo é vista prioritariamente como um dos grandes responsáveis pela 'mudança de vida' da 'nova classe média'(Ibdem, grifos do autor).

Então, os meios de comunicação hegemônicos tiveram e têm papel fundamental na reprodução desta crença acerca do surgimento de uma "nova classe média" brasileira (SIFUENTES, 2014). Assim, a mídia e diversos intelectuais, majoritariamente neoliberais, semeiam e reforçam a ideia de que parte da população que teve crescimento na renda e saiu da linha da pobreza são pertencentes a

[...] uma nova classe média, que está transformando o Brasil no país moderno e de primeiro mundo que foi e é o maior sonho coletivo de seu povo desde a independência política em 1822. Dizer que os emergentes são a nova classe média é uma forma de dizer, na verdade,

\footnotetext{
${ }^{51}$ Dis ponível em: https://www.ipea.gov.br/portal/index.php?option=com_alphacontent \&view=alphacontent $\&$ Itemid=35 7. Acesso em de 2019. agosto
} 
que o Brasil finalmente, está se tornando uma Alemanha, uma França ou uns Estados Unidos, onde as classes médias, e não os pobres, os trabalhadores e os excluídos, como na periferia do capitalismo, formam o fundamento da estrutura social (SOUZA, 2010, p. 20).

Para Pochmann (2012, p.7), este viés político propagado pelos meios de comunicação acerca desta concepção de que o Brasil possui uma "nova classe média" é nada menos que um "oráculo midiático" que defende o consumismo e nega a estrutura de classe moldada pelo capitalismo. Além do que a utilização desta expressão "resulta, em consequência, no apelo à reorientação das políticas públicas para a perspectiva fundamentalmente mercantil" (Ibdem, p. 11). A expressão cunhada por Neri (2008) também pode ser considerada

[...] como uma marca em seu sentido publicitário e político: publicitário, na medida em que essa marca serve a pesquisas de opinião e marketing, às empresas de comunicação e à própria publicização (Casaqui,2011) nos mais diferentes dispositivos; político, e quase sempre conectado ao sentido publicitário, pois serviu como uma marca de governo relacionada ao período Lula/Dilma (GROHMANN, 2016, p. 158).

O próprio Neri $(2008,2010)$ explica que a terminologia proposta diz respeito à uma classe econômica e não a uma classe social, portanto, é uma "nova classe média" no sentido estatístico e não sociológico. No entanto, tal diferenciação não foi discutida e nem levada em consideração, visto que a mídia hegemônica veiculou a ideia de que sim, o Brasil possui uma "nova classe média" (SIFUENTES, 2014).

Souza (2010) analisa este otimismo acerca da "nova classe média" como um olhar completamente distorcido e deliberado por parte da cultura dominante, sem levar em consideração as contradições, as lutas e os fatos que fizeram com que esta parcela da população ascendesse. Para ele, a omissão desses conflitos ameniza a distinção de classe e não promove reflexões sobre a desigualdade social, e, enaltece a aquisição de bens materiais como solução para mudança de vida destes agentes, resultando, assim, numa violência simbólica

[...] sempre que não se percebem a construção e a dinâmica das classes sociais na realidade temos, em todos os casos, distorção da realidade vivida e violência simbólica, que encobre dominação e opressão 
injusta. A razão para que isso aconteça também é simples. Como é o pertencimento às classes sociais que predetermina todo acesso privilegiado a todos os bens e recursos escassos que são o fulcro da vida de todos nós 24 horas por dia, encobrir a existência das classes é encobrir também o núcleo mesmo que permite a reprodução e legitimação de todo tipo de privilégio injusto (Ibidem, p. 22).

Pochmann (2012, 2014), contrário a esta visão predominante da existência de "nova classe média" brasileira, é categórico ao afirmar

[...] que não se trata da emergência de uma nova classe- muito menos de uma classe média. O que há, de fato, é uma orientação alienante sem fim, orquestrada para o sequestro do debate sobre a natureza e a dinâmica das mudanças econômicas e sociais, incapaz de permitir a politização classista do fenômeno de transformação da estrutura social e sua comparação com outros períodos dinâmicos do Brasil (POCHMANN, 2012, p. 8).

O economista lança mão dos dados econômicos positivos do país nos anos 2000, mas interpreta-os de maneira distinta à visão proposta por Neri $(2008,2010)$. Pochmann $(2012,2014)$ ressalta dois fatos que proporcionaram a renovação atual da pirâmide social do Brasil. O primeiro deles foi em 1994, após a implantação do Plano Real, no governo Itamar Franco, em que houve uma diminuição na participação dos salários na renda nacional (9\% entre 1995 e 2004) e o aumento das rendas da propriedade com lucros, aluguéis, terras, etc. com um crescimento de $12,3 \%$. O segundo foi com o término do governo Lula, em que, ao longo dos anos de 2004 a 2010, houve um aumento da participação dos salários na renda do país, o que significou $10,3 \%$ de crescimento no período. Além disso, houve um decréscimo de $12,8 \%$ no peso relativo da propriedade. As políticas sociais e o apoio ao crédito também foram determinantes nesse período. Com base nos dados, Pochamann (2014, p. 71) ainda afirma que "o Brasil combinou crescimento econômico com distribuição de renda, o que permitiu a retomada da mobilidade social, especialmente aquela associada à base da pirâmide social". Desta forma, uma grande parcela da população pertencente à classe trabalhadora, assim como o que acontece nos países de capitalismo avançado, foi incorporada no consumo de bens duráveis (como carro, televisão, fogão, geladeira, computador, etc.), do que anteriormente estavam à 
margem. $\mathrm{O}$ autor acrescenta que assim foi difundido o consumo de baixo custo, ou seja, "a sociedade low cost ganhou notoriedade, especialmente com o deslocamento da produção manufatureira para os países asiáticos, sobretudo a China" (Ibdem, p. 113).

Com isso, Pochamann $(2012$, 2014) e Souza $(2010,2013)$ propõem de, em vez de denominar esta parcela ascendente da população de "nova classe média", chamála de "nova classe trabalhadora". Isto porque existem "diferenças marcantes entre o habitus desse grupo e aquele reconhecido como classe média" (OLIVEIRA-CRUZ, 2016, p. 29). Podemos dizer ainda que este novo grupo é uma fração ascendente da classe popular. Concordamos com esta concepção, pois acreditamos nesta abordagem que vai para além do econômico e que permite observarmos as mudanças na experiência do cotidiano dos agentes, bem como na conformação de suas identidades. Por isso, nesta tese, é essa perspectiva que adotamos, porém utilizaremos aqui o termo "classe média baixa", pois se faz mais adequado para o nosso contexto de pesquisa e conforme o nosso livro inspiração. Estes aspectos concernentes à composição da nossa amostra de pesquisa empírica será exposto no próximo capítulo (Capítulo 5).

Esta nova classe trabalhadora conseguiu sair do círculo vicioso ao qual pertencia, ou seja, sem incorporação familiar, escolar e social (SOUZA, 2013). O autor destaca que o autocontrole e a disciplina com relação ao trabalho puro, bem como o comportamento e o pensamento que visam enxergar ao longe são os valores que fazem parte das condições para o trabalho útil relacionado à ascensão desta fração de classe. Conforme Sifuentes (2014), estes valores são percebidos por meio das longas jornadas de trabalho em que a remuneração é atrelada à produtividade e de cursos noturnos, sejam eles de ensino superior ou técnico. Além das longas jornadas de trabalho, exigindo cansaço físico e psicológico, muitos destes trabalhadores são vinculados ao trabalho precarizado (FLEURY, 2013).

Souza (2010) identifica que a nova classe trabalhadora (que ele denominou de "batalhadora") ascendeu também como consequência de sua disciplina, empenho pessoal e outras pré-disposições que as diferenciam da fração mais baixa da classe popular, que o autor nomeou de "ralé". Por sua vez, tal fração da classe média (nova classe trabalhadora) "anseia pelo mesmo nível de consumo da alta classe média" (SOUZA, 2018, p. 131). 
Vemos como importante deixar claro que nossa intenção com a discussão sobre a "nova classe média" não está sendo colocada para que se encontre uma melhor nomenclatura para ou mesmo estratificação de um grupo social, pois concordamos com Oliveira-Cruz (2016) no fato de que, quando se tenta localizar uma fração de classe no espaço social, o que estamos fazendo é um esforço para problematizar e tentar compreender a dinâmica deste subcampo com seus conflitos, transformações e relações com os demais grupos da sociedade.

Seguindo Souza (2010), concebemos que a ascensão desta fração de classe significa um fenômeno novo e que esta classe, assim como todas as outras, é complexa e possui características também novas que acabam por a diferenciar da classe trabalhadora que existia em outros períodos. Ou seja, é

[...] uma classe social nova e moderna, produto das transformações recentes do capitalismo mundial, que se situa entre a 'ralé' e as classes média e alta. Ela é uma classe incluída no sistema econômico, como produtora de bens e serviços valorizados, ou como consumidora crescente de bens duráveis e serviços que antes eram privilégio das classes média e alta (Ibdem, p.26).

Por conseguinte, tem relevância a observação de como, na cultura do vivido, há a possibilidade de formação, mesmo que ainda em processo, de uma cultura de classe (OLIVEIRA-CRUZ, 2016), isto é, “um conjunto 'distinto e peculiarmente formado' de 'sentimentos, maneiras de pensar e visões de vida' de sua experiência coletiva, em que membros continuamente se inspiram em suas tentativas de compreender a situação" (MURDOCK, 2009, p. 36, grifos do autor). A cultura de classe é intimamente ligada à noção de identidade de classe, sendo esta a reivindicação de pertencimento a um determinado grupo social, caracterizado por disputas (SALATA, 2015), sendo que as identidades de classe

[...] são compreendidas, portanto, como um processo em eterno movimento, nunca acabado, nunca resolvido, envolvendo o constante entendimento de quem somos e de quem as outras pessoas são, e, reciprocamente, o entendimento de outras pessoas sobre elas mesmas e sobre os outros (Ibdem, p.114).

Assim, a consciência de classe pode diferenciar-se de acordo com a experiência de desigualdade social vivida pelos agentes (MURDOCK e MCCRON, 2003; 
SALATA, 2015).

Apesar dos números positivos e desta certa mobilidade na base da pirâmide social recém discutida, houve um recuo, especialmente nos últimos anos. De acordo com Souza (2018), o crescimento do Brasil com registro de altas taxas anuais durante os governos petistas de Lula e Dilma foi acometido pelo sistema financeiro bancário com a alta abusiva de juros. O sociólogo afirma que, em 2005, a dívida das familias brasileiras equivalia a $18,42 \%$ de sua renda mensal e, em 2013, esse número aumentou para 43,86\%, atingindo $46 \%$ em 2015. E complementa:

Uma vez que a população como um todo estava aumentando seu poder de compra, os bancos decidiram- a partir de seu bunker no Banco Central e com a desculpa de combater a inflação- botar no bolso dos rentistas, elite e alta classe média, a riqueza que era coletiva. A dívida cresce na medida em que tarifas absurdas, como os $5 \%$ de toda compra a crédito no cartão, vão enforcando as famílias até que, em 2018, chegamos a 64 milhões de pessoas no cadastro de inadimplentes (Ibdem, p. 271).

Então, o conceito de classe social é complexo e não pode ser tomado como objetivo, estático e muito menos relacionado apenas às questões econômicas, mas ao conjunto dos capitais e valores simbólicos que são incorporados às culturas de classe e que posicionam socialmente os sujeitos, assim, diferenciando-os. Tendo em vista todas essas questões, o que investigamos nesta tese é se a mediação de classe social continua sendo estruturante na recepção da telenovela mesmo nessa época de transmidiação e convergência em que muitas fronteiras físicas e sociais parecem ser apagadas pelas novas tecnologias. 


\section{Capítulo 5: A metodologia na pesquisa empírica}

Neste capítulo, explicitamos e justificamos as estratégias metodológicas utilizadas para construção e execução da pesquisa de campo com as duas famílias informantes baseadas nas premissas teóricas, epistemológicas e metodológicas já explicitadas nos capítulos anteriores. Relatamos este percurso iniciando pelo livro que serviu de inspiração desta tese, em seguida pontuamos questões relacionadas às premissas multimetodológicas que guiam e norteiam a investigação realizada bem como às mediações escolhidas para o estudo da recepção da telenovela. $\mathrm{Na}$ sequência, apresentamos o protocolo multimetodológico da pesquisa empírica e explanamos como ele foi elaborado. As técnicas de coleta para explorar as mediações no processo receptivo, a composição da nossa amostra e o corpus da pesquisa também estão colocadas nesta parte do texto. O último subtópico do capítulo diz respeito a uma reflexão epistemológica concernente aos percalços enfrentados durante o processo de pesquisa, especialmente na pesquisa empírica com as famílias.

\subsection{Vivendo com a telenovela: o livro inspiração}

Figura 15: Capa do livro Vivendo com a telenovela: mediações, recepção, teleficcionalidade (LOPES, BORELLI e RESENDE, 2002).

Fonte: Divulgação internet

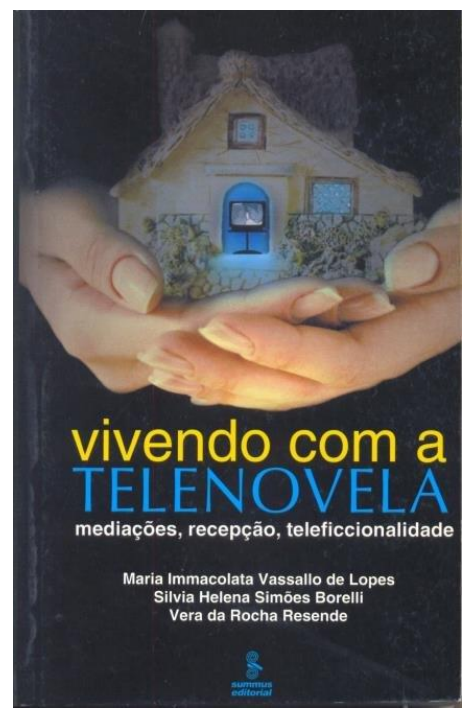


O livro clássico de recepção de telenovela: Vivendo com a telenovelamediações, recepção, teleficcionalidade (LOPES, BORELLI e RESENDE, 2002) ${ }^{52}$, conforme já mencionamos, motivou e inspirou esta tese de doutorado. Tal livro é o resultado de uma pesquisa de recepção da telenovela A Indomada, escrita por Aguinaldo Silva e Ricardo Linhares e exibida em 1997 pela Globo. E é resultado de um projeto integrado e multidisciplinar realizado por Maria Immacolata Vassallo de Lopes (coordenadora), Silvia Simões Borelli e Vera da Rocha Resende e uma equipe de pesquisadores e colaboradores. A investigação foi realizada com uma amostra de quatro familias de diferentes classes sociais moradores de uma favela, de periferia, de bairro de classe média e de condomínio fechado de classe média alta, da cidade de São Paulo, durante o tempo em que a telenovela esteve no ar, de fevereiro a outubro de 1997.

O conceito de classe social foi aplicado como estruturante para investigar a recepção da telenovela nas diferentes famílias. As autoras utilizaram a etnografia no cotidiano familiar para mapear o processo receptivo em pessoas com distintas visões de mundo. A perspectiva das mediações de Martín-Barbero (1987) também foi eixo teórico da pesquisa na análise e articulação de como cada medição incidia no processo receptivo como um todo.

Em Vivendo, é apresentado um rico material empírico que nos faz pensar a recepção e as inúmeras estratégias que este tipo de pesquisa metodológica propicia. Segundo Martín-Barbero (2002b, p. 11), o livro

[...] narra uma rara e apaixonante aventura intelectual. Além da problemática da telenovela, ou da recepção de telenovelas, do que na verdade aqui se fala é de uma longa e sistemática exploração metodológica, com a qual se procura traduzir a proposta teórica das mediações em estratégias de pesquisa.

As autoras investigaram a telenovela tanto no espaço da produção como no "tempo do consumo, ambos articulados pela cotidianidade (usos/consumo/práticas) e pela especificidade dos dispositivos tecnológicos e discursivos (gêneros ficcionais) do meio televisão" (LOPES, BORELLI e RESENDE, 2002, p. 40) ${ }^{53}$. Assim, foram

\footnotetext{
${ }^{52}$ A partir de agora, ao longo do texto, nos referenciaremos à obra apenas como Vivendo a título apenas de simplificar e dar maior fluidez à escrita.

${ }^{53}$ Todas as citações da obra neste tópico serão feitas apenas pelas páginas.
} 
articulados quatro lugares de mediação para realizar a pesquisa: 1) o cotidiano familiar; 2) a subjetividade; 3) o gênero ficcional; 4) a videotécnica. Essas mediações foram selecionadas de acordo com as exigências metodológicas demandadas pelo aporte multidisciplinar presente, tanto no processo comunicativo como um todo quanto na própria teoria das mediações. A classe social aparece como mediação de nível estrutural para analisar o processo de construção de sentido pelas quatro famílias investigadas. A justificativa da estratégia metodológica utilizada para articular quatro mediações é a seguinte:

- Cotidiano e Subjetividade: mediações localizadas na recepção e reapropriadas no gênero e na videotécnica;

- Gênero: mediação localizada no produto e reapropriada no cotidiano, na subjetividade e na videotécnica;

- Videotécnica: mediação localizada na produção e reapropriada no gênero, no cotidiano e na subjetividade. (p. 47-48, grifos das autoras).

Ainda sobre a estratégia multimetodológica, foram combinadas diversas modalidades de técnicas de pesquisa a fim de saturar os dados empíricos através dos mais variados ângulos. Para esse fim, as pesquisadoras lançaram mão de dez técnicas qualitativas: Observação Etnográfica; Entrevista do Cotidiano; Entrevista da Subjetividade; Entrevista do Gênero Ficcional; Entrevista da Videotécnica; História de Vida; Entrevista da Produção; História de Vida Cultural; Grupo de Discussão; Telenovela Reeditada e uma técnica quantitativa: o Questionário de Consumo.

O corpus da pesquisa foi composto pela gravação em vídeo de todos os capítulos da telenovela A Indomada, e a seguir, foi extraído um corpus reduzido constituído pelas sequências da trama escolhidas como mais significativas pelas famílias. Essa reedição da telenovela foi usada em grupo de discussão com os receptores.

Os dados foram tabulados e transcritos através de um programa de computador para pesquisa qualitativa, chamado WinMax. A única mediação que não teve tratamento de análise nesse programa foi a videotécnica, que foi trabalhada a partir de técnicas de decupagem e de digitalização.

Entre as inúmeras contribuições propiciadas por uma pesquisa de recepção integral está que o cotidiano vivido pelas famílias não foi abordado apenas no momento da recepção da telenovela, uma vez que, a aplicação de técnicas, como entrevista 
individual e familiar e o questionário, por exemplo, permitiram extrapolar esse momento para reconstituir os mais diferentes cotidianos das quatro famílias. Outro resultado mostrou que "a telenovela propõe uma agenda temática que, por diferentes mecanismos, insere-se no cotidiano dos telespectadores; ou seja, as questões colocadas pela telenovela passam a ser consideradas de interesse público" (p. 367-368). Desta forma, o uso da novela depende da dimensão simbólica por cada sujeito e cada grupo social bem como as lógicas de usos acabam por

[...] superar os limites de classe social e respondem a demandas próprias do universo psíquico, do gênero, da geração e do perfil ideológico. Entretanto, independentemente do sentido construído por cada grupo ou pessoa, observamos um repertório compartilhado (p. 368 , grifo das autoras).

Foi observado ainda que o alto grau de exposição a telenovelas não significa que os receptores tenham baixos níveis de análise crítica ou de politização. Portanto, a lógica da produção e da recepção acontece "de forma dinâmica e intercambiante" (p. 369) e não de correspondência mecânica. Porém foi detectado que a relação entre os integrantes das famílias e a telenovela acontece de forma mais intensa nas duas famílias de classe popular (classe média baixa e classe baixa). Tal fato foi explicado por "uma forte matriz narrativa melodramática, identificada por meio das histórias de família e das histórias de vida cultural dessas pessoas" (p. 369, grifos das autoras). Nas famílias de classe alta, há um relacionamento com a telenovela mais "racionalizado, latente e contraditório" (p. 369, grifo das autoras). Mesmo assim, ficou claro que todas as familias estudadas relacionam-se, em menor ou maior grau, com o universo da telenovela também por meio dos consumos de rádio, de música, de revistas e de outros programas televisivos. E, se trouxermos para uma conceituação atual, podemos identificar tais consumos como sendo uma recepção transmídia.

A classe social como mediação estrutural é justificada pelas autoras pelo fato de que as diferentes condições de classe e a distinção de consumo cultural acabam por condicionar a intensidade de assistência e as relações com a telenovela. Também, a mediação do cotidiano é determinante e marca profundamente as leituras que os receptores fazem da telenovela. Desta forma,

a pesquisa verificou a existência de matrizes de representação de classe, de gênero e de religião. Ou seja, cada grupo familiar (classe), 
enquanto receptor, cria um 'palimpsesto cotidiano' que depende da competência cultural e de suas características socioeconômicas (p. 370 , grifos das autoras).

No que diz respeito à subjetividade, as pesquisadoras afirmam que a interface dessa mediação com a telenovela deu lugar à regulação de trocas, vigilância, fuga e experiência de controle, permitindo "novo acesso a novos espaços, à realidade mais ampla de produção social da subjetividade" (p. 374). Isso faz com que a recepção reconstitua novos lugares, intercâmbios e novos começos de existência. Acrescentam que vida a dos personagens da trama entrecruza-se com a vida das pessoas, num processo mútuo e dialético.

No âmbito da mediação do gênero ficcional, foi concluído que as distintas leituras de A Indomada são feitas por familias de diferentes características empíricas, definidas a partir da condição de classe social. Foi constatado ainda que há um "certo caráter de universalidade do gênero ficcional, decifrado como tal pelas famílias distintas” (p. 375). As autoras destacaram a capacidade que a ficção tem de elaborar um imaginário coletivo e ainda articular todos os fragmentos que compõem os imaginários dos produtores e dos receptores.

A investigação da mediação videotécnica permitiu que fossem identificados os elementos que compõem a linguagem "que deflagram determinados sentidos e constituem um repertório que é compartilhado entre os sujeitos da produção e do consumo" (p. 377, grifos das autoras). Conforme as autoras, as leituras dos receptores são seletivas e ocorrem de acordo com o contexto de interação e vivência destes telespectadores. Assim, foi possível inferir que os modos de ver os elementos de caracterização dos personagens e composição cênica dialogam com o contexto cultural imediato em que vivem os receptores. A conclusão é de que as pessoas, mesmo sem o conhecimento especializado, reconhecem a gramática e têm a competência de identificar técnicas de produção da ficção em assistência.

A respeito das experiências proporcionadas pela investigação, as autoras afirmam que, através de um trabalho de campo exaustivo, foi possível acompanhar e reconstituir a rotina dos receptores, seu cotidiano e sua relação com a telenovela. Isso foi fundamental para que fosse garantida uma relação de empatia entre pesquisadores e pesquisados. A aplicação de um protocolo multimetodológico mostrou-se fundamental 
para captar todos os movimentos diacrônicos e sincrônicos tanto da vida dos receptores quanto da trama narrativa.

A pesquisa finaliza com uma importante reflexão de caráter epistemológico, de autocrítica, que aponta para a pesquisa de recepção como ponto de vista. Ou seja, um lugar de partida para a reconstituição não apenas do processo receptivo, mas para a integração num único ato de pesquisa de todas as instâncias e aspectos compreendidos no processo comunicativo (produção, circulação e recepção).

\subsection{Premissas multimetodológicas}

O critério metodológico em si faz com que o pesquisador tenha que escolher entre uma variedade de métodos de análise disponíveis em uma ciência interdisciplinar como a Comunicação, exigindo, assim, a opção por múltiplos métodos. Já o critério operacional de uma pesquisa diz respeito "ao domínio de um repertório variado de metodologias, técnicas e instrumentos que enriqueça o momento da opção" (LOPES, 2014, p. 110). Mas este domínio implica um conhecimento de referência e não um conhecimento exaustivo de todas as metodologias possíveis de serem utilizadas. Com base nisto, explicitamos a seguir, os percursos traçados e as escolhas para montar a metodologia na nossa pesquisa.

Compreendemos que a recepção é "uma perspectiva de investigação, e não uma área de pesquisa sobre mais um dos componentes do processo de comunicação, neste caso, o público" (LOPES, BORELLI e RESENDE, 2002, p. 39, grifos das autoras). Para pensar a recepção, é preciso que se chegue à produção, pois o processo comunicativo é dialético entre a produção e a recepção, haja vista que "[..] o processo de recepção é, ao mesmo tempo, território compartilhado por produtores e consumidores, e cenário de luta pela interpretação mais legítima do sentido" (MARTÍNBARBERO, 2002b, p. 15). Assim, apesar de estarmos fazendo um estudo de recepção, não deixamos de considerar o processo comunicativo como um todo, pois "a recepção não é algo aberto e perfeitamente transparente, que acontece na outra ponta da cadeia de comunicação" (HALL, 2006, p. 334).

Deste modo, conforme já explicitamos anteriormente neste texto, e em conformidade com Lopes, Borelli e Resende (2002), concebemos que o processo comunicativo é articulado a partir das mediações: 
Investigar a telenovela exige pensar tanto o espaço da produção como o tempo de consumo, ambos articulados pela cotidianidade (usos/consumo/práticas) e pela especificidade dos dispositivos tecnológicos e discursivos (gêneros ficcionais) do meio televisão (LOPES, BORELLI e RESENDE, 2002, p. 40).

Então, elaboramos, seguindo o livro inspiração, uma multimetodologia para investigar a recepção da telenovela mobilizando os mapas das mediações de MartínBarbero (1987, 1998, 2010, 2017), principalmente os mapas 1,4 e 2 já apresentados no capítulo 2. Desta forma, "as mediações só ganham sentido ao serem relacionadas entre si, dentro de determinado contexto, independentemente do campo específico sobre o qual se esteja trabalhando" (LOPES, BORELLI e RESENDE, 2002, p. 43). Esta decisão não foi tomada de forma aleatória, mas conforme as demandas da nossa pesquisa, visto que

A apropriação dos mapas pelo pesquisador depende da estratégia metodológica que adotar em uma dada pesquisa empírica, de modo que a escolha pode recair em determinadas mediações e não em outras dependendo do destaque que ganham na abordagem analítica (LOPES, 2018, p. 60).

Diante disso, estudamos a recepção da telenovela a partir da articulação de oito principais mediações: temporalidades, narrativas, tecnicidades, redes, espacialidades, cidadanias, sensorialidades e identidades. Reiteramos que todas as mediações são articuladas entre si, mas, a título de operacionalização empírica, subdividimos elas em nossa análise. Portanto, as temporalidades são estudadas em articulação com a sociabilidade no cotidiano familiar dos receptores estudados; as espacialidades observadas com a ritualidade na assistência da telenovela; as sensorialidades associadas às identidades e cidadanias dos receptores e, por fim, as tecnicidades em relação às narrativas, redes e ao gênero ficcional. Acrescentamos que a mediação de classe social perpassa todas estas mediações recém citadas, pois nosso objetivo é averiguar se, na atualidade, ela continua sendo mediação estrutural na recepção da telenovela, como detectado no livro inspiração. Nosso objetivo com isto foi tecer uma verdadeira malha complexa "de interações recíprocas entre produção, o produto e a recepção" (LOPES, BORELLI e RESENDE, 2002, p. 41). 
Optamos por combinar e mobilizar mais de um mapa e todas essas mediações porque apostamos, assim como as autoras do livro inspiração, em uma proposta multimetodológica de pesquisa que atravessa todos os níveis da pesquisa, desde o epistemológico-teórico - por meio da perspectiva multidisciplinar da Teoria Barberiana da Comunicação, passando pelo paradigma de classe social e da cultura da convergência - até o nível técnico-empírico através do modelo multimetodológico das mediações. Tal proposta é adequada também pelo fato de que, por meio dela, podemos explorar de maneira a saturar cada mediação estudada na recepção da telenovela. E ainda porque uma pesquisa multimetodológica se faz necessária para que se possa perfazer a complexidade do objeto comunicativo e sua interdisciplinaridade (LOPES, 2004).

A seguir, apresentamos um diagrama que ilustra esta mobilização dos três mapas:

Figura 16: Diagrama da mobilização dos mapas na pesquisa empírica

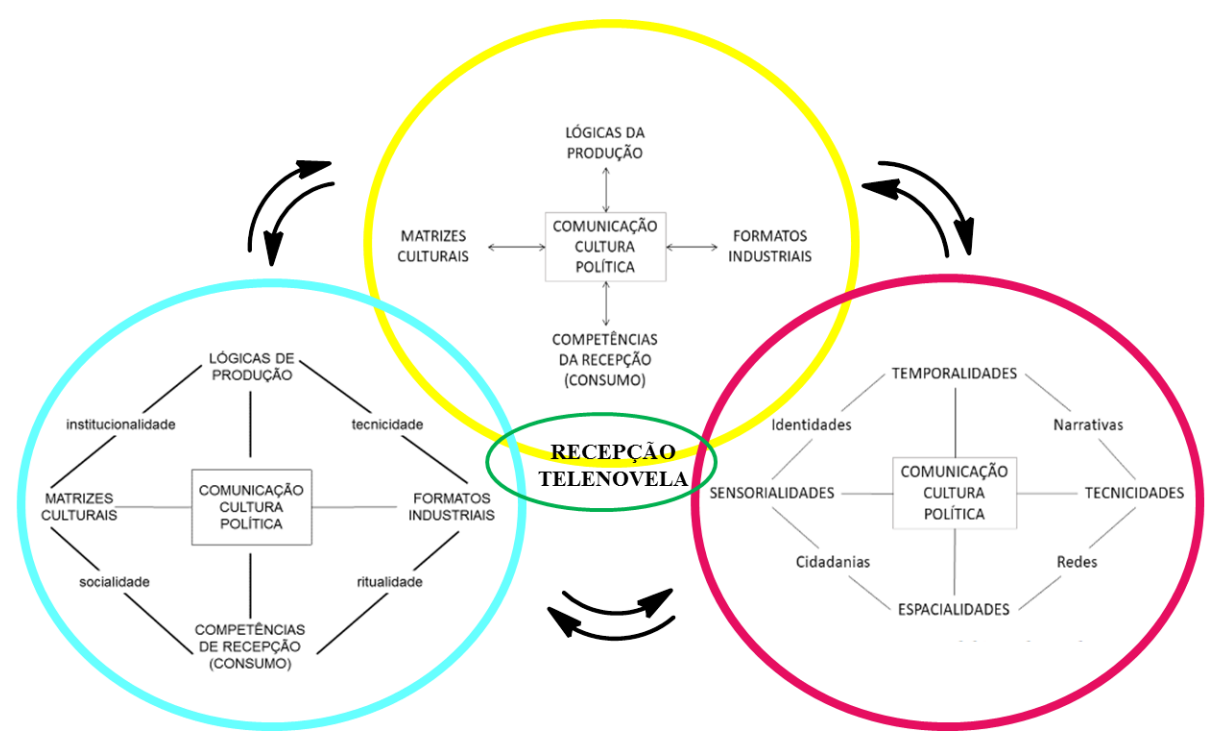

Fonte: Elaboração da autora

\subsection{Protocolo Multimetodológico da pesquisa empírica}

O processo de observação, conforme Lopes (2014), tem por objetivo reconstruir empiricamente a realidade, ou seja, coletar evidências concretas que sejam capazes de 
reproduzir os fenômenos que estão sendo estudados. Esta fase está diretamente relacionada aos pressupostos teóricos da pesquisa "que repercutem na reconstrução empírica dos fenômenos e, por outro, deve desenvolver técnicas de controle do próprio processo de observação" (Ibdem, p. 142). Por isso, a autora alerta para a necessidade de “integração metodológica” (Ibdem) entre o momento da observação (caráter técnico) e o posterior a ela, que é de explanação (caráter lógico), o que exige do pesquisador uma estratégia de pesquisa antes mesmo de ir de fato a campo.

Ainda segundo a autora, a reprodução da realidade vista na fase da observação demanda uma série de atividades intelectuais que são complexas porque "o importante não é o que se vê, mas o que se vê com método, pois o investigador pode ver muito e identificar pouco e pode ver apenas o que confirma suas concepções” (Ibdem, p. 143). Portanto, a observação é o momento da pesquisa em que a ruptura epistemológica acontece na prática. É uma fase regulada por operações dos níveis técnico e metódico e abrange duas operações diferentes, a amostragem e a coleta de dados. Trataremos primeiro da coleta de dados.

Assim como em Vivendo, também utilizamos um protocolo multimetodológico "que pudesse sintetizar os avanços da teoria das mediações numa pesquisa empírica" (LOPES, BORELLI e RESENDE, 2002, p. 48) e a fim de operacionalizar de maneira mais clara a pesquisa de campo. Mesmo baseado no protocolo desenvolvido pelas autoras do livro inspiração, elaboramos o nosso próprio, atualizando-o com as demandas da nossa pesquisa.

Foram combinadas 8 técnicas de pesquisa para estudar a recepção da telenovela a partir das mediações. Tais técnicas foram utilizadas porque são adequadas à teoria, ao problema e ao objeto de pesquisa. Mas temos a consciência de que o esforço feito aqui tem o objetivo de reconstruir empiricamente a realidade, ou seja, coletar evidências concretas que sejam capazes de reproduzir os fenômenos que estão sendo estudados (LOPES, 2014). Por esta razão, as técnicas não são neutras, seja no momento da sua opção ou na sua construção. Além do mais, não podem ser vistas como regras, ou "receituários" que apenas explicitam "como fazer", já que são "teorias em ato" (BACHELARD apud LOPES, 2014, p. 133).

Logo, as técnicas foram organizadas e articuladas com cada mediação conforme o quadro a seguir: 


\section{Figura 17: Protocolo Multimetodológico da pesquisa empírica}

\begin{tabular}{|c|c|c|c|c|c|c|c|c|}
\hline Mediacōes & Temporalidades & Narrativas. & Tecnicidades & Redes & Espacialidades & Cidadanias & Sensorialidades & Identidades \\
\hline \multicolumn{9}{|c|}{$\begin{array}{l}\text { Coleta de Dados } \\
\text { 1. Trabalho de campo com duas familias }\end{array}$} \\
\hline $\begin{array}{c}\text { Técnica } \\
\text { Quantitativa }\end{array}$ & QC & $Q C$ & $Q C$ & QC & $Q \mathrm{C}$ & QC & QC & QC \\
\hline \multirow{4}{*}{$\begin{array}{l}\text { Técnica } \\
\text { Qualitativa }\end{array}$} & $\mathrm{OE}$ & $\mathrm{OE}$ & $\mathrm{OE}$ & $\mathrm{OE}$ & $\mathrm{OE}$ & $\mathrm{OE}$ & $\mathrm{OE}$ & $\mathrm{OE}$ \\
\hline & EG & EG & EG & & HV & HV & HV & HV \\
\hline & 00 & oo & 00 & oo & oo & oo & o० & 00 \\
\hline & GD & GD & GD & GD & GD & GD & GD & GD \\
\hline \multicolumn{9}{|c|}{ 2. Corpus: TVN todos os caoítulos. } \\
\hline & TVN-R & TVN-R & TVN-R & TVN-R & TVN-R & TVN-R & TVN-R & TVN-R \\
\hline & Sinoose & Sinoose & Sinoose & & & & Sinoose & \\
\hline & Clipping & Clipping & Clipping & & & & Clipping & \\
\hline \multicolumn{9}{|c|}{ Tratamento dos Dados } \\
\hline $\begin{array}{l}\text { Transcricão } \\
\text { instrumentos }\end{array}$ & Todos & Todos & Todos & Todos & Todos & Todos & Todos & Todos \\
\hline $\begin{array}{l}\text { Tabulacão por } \\
\text { mediacảo }\end{array}$ & Maxada & Maxqda & Maxqda & Maxqda & Maxqda & Maxqda & Maxqda & Maxqda \\
\hline Análise & Estudo de caso & $\begin{array}{l}\text { Análise } \\
\text { gênero } \\
\text { ficcional }\end{array}$ & $\begin{array}{c}\text { Análise gênero } \\
\text { ficcional; Estudo } \\
\text { de caso }\end{array}$ & $\begin{array}{l}\text { Análise de } \\
\text { conteúdo }\end{array}$ & $\begin{array}{l}\text { Análise de } \\
\text { conteúdo }\end{array}$ & $\begin{array}{l}\text { Estudo de } \\
\text { caso }\end{array}$ & Estudo de caso & Estudo de caso \\
\hline
\end{tabular}

Fonte: Elaborado pela autora

\section{Legenda:}

QC: Questionário de consumo

OE: Observação etnográfica

HV: História de vida

HC: História de vida cultural

EG: Entrevista de gênero ficcional

OO: Observação on-line

GD: Grupo de discussão

TVN-R: Telenovela reeditada

Utilizamos, então, 7 técnicas qualitativas e 1 quantitativa para apurar as mediações no âmbito da recepção da telenovela. A união destas múltiplas técnicas de observação/coleta das mediações, como já mencionamos, tem por finalidade a saturação de sentido, visto que uma das formas de uma metodologia qualitativa lidar com a subjetividade implícita nos dados é tentar objetivá-los, através do processo de saturação de sentido de um fato, no nosso caso, a saturação do sentido da recepção da telenovela em cada família estudada (LOPES, BORELLI e RESENDE, 2002).

Deste modo, apresentamos a nossa concepção e como foram pensadas cada uma das técnicas em nossa pesquisa. Seguem: 
Questionário de Consumo (QC)

Nosso único instrumento quantitativo, o questionário é uma técnica de observação indireta (LOPES, 2014). Esclarecemos que, apesar de ser uma técnica quantitativa, os dados obtidos por meio dela não foram tratados de forma estatística, pois nossa pesquisa é, em sua essência, qualitativa. O que foi respondido no QC serviu para que se pudesse traçar o perfil socioeconômico dos informantes, bem como oferece os indicadores quantitativos acerca do consumo de mídia e da organização e sentido que dão a este consumo. O questionário é mais objetivo se comparado com as outras técnicas que empregamos. Ele foi elaborado a partir da premissa de que "a lógica dos usos em que o consumo e os usos dos meios são vistos como processos sociais de apropriação de bens materiais e simbólicos que contribuem para a estruturação das características subjetivas e coletivas das pessoas" (BOURDIEU, 1991; CERTEAU, 1994; GARCÍA CANCLINI, 1995 apud LOPES, BORELLI e RESENDE, 2002, p. 55, grifos das autoras).

$\mathrm{O}$ QC foi o primeiro instrumento a ser aplicado na pesquisa, pois, por ser uma das "técnicas mais frias" (LOPES, BORELLI e RESENDE, 2002, p. 57), não exigiu neste primeiro contato que os receptores tivessem que dar nenhum testemunho concernentes à sua vida, o que surgiu ao longo das outras técnicas de coleta e das conversas durante a observação participante. Isto possibilitou também que pesquisadora e pesquisados pudessem se conhecer aos poucos, estabelecendo uma aproximação e compreensão mútua gradativa.

Entrevista de gênero ficcional (EG)

A entrevista é a técnica mais usual na investigação qualitativa nas Ciências Sociais (OROZCO e GONZÁLEZ, 2011; POUPART et al., 2008) e consiste em uma série de perguntas feitas aos informantes (entrevistados). Para Poupart et al. (2008, p. 247), a entrevista ultrapassa a dimensão técnica, pois envolve questionamentos de ordem epistemológica, teórica e metodológica. Isto porque não há neutralidade do pesquisador, já que é "uma co-construção da qual tomam parte tanto o entrevistador quanto o entrevistado". 
Nossa entrevista de gênero ficcional realizada foi semiaberta, ou seja, com roteiro fechado, composto por questões-guia e aberto, que também possibilita ao entrevistado falar sobre questões que não estão neste roteiro (THIOLLENT, 1980; DUARTE, 2009). Duarte (2009) ainda acrescenta que este tipo de entrevista reúne a flexibilidade das questões não estruturadas com um roteiro controle, que exige poucas questões, mas que são amplas e podem ser discutidas em profundidade.

Elaboramos essa entrevista com o intuito de captar dos receptores as suas percepções sobre a telenovela estudada, suas interpretações sobre os personagens da telenovela e suas tramas, a "competência textual narrativa capaz de articular a narrativa do melodrama e dos diferentes territórios de ficcionalidade com as narrativas dos receptores" (LOPES, BORELLI e RESENDE, 2002, p. 58, grifos das autoras). Ainda para detectar nas falas dos informantes as "marcas de reconhecimento da matriz popular da telenovela" (Ibdem, p. 58), incluímos nessa entrevista perguntas que permitissem a observação daquilo que envolve o conhecimento dos elementos da linguagem audiovisual e seus aspectos técnicos, a fim de se ter uma noção da competência técnica dos receptores. E, por último, para identificarmos algumas pistas sobre a construção do "repertório compartilhado" (Ibdem, p. 58) entre a produção e a recepção.

Esta entrevista foi realizada com alguns receptores no mês anterior ao final da telenovela e com outros dias após o final (de acordo com as disponibilidades deles) porque assim, foi possível que eles tivessem uma ideia mais global sobre a trama para poder responder a todas as perguntas, mais do que se fosse aplicada no início.

História de vida (HV)

A técnica consiste em uma entrevista em profundidade não estruturada, aberta e permite que o entrevistado descreva e conte sua história de vida. Porém, montamos o roteiro com temas guias para nortear o relato dos informantes e garantir que as questões pertinentes à pesquisa não fossem excluídas do relato (como o que envolve família atual, infância, trabalho, relações interpessoais, escola, lazer). Tais temas foram introduzidos e os entrevistados tiveram a liberdade de discorrer sobre eles. A entrevista foi realizada de forma que os informantes contassem sua história de forma cronológica.

Com a HV foi possível ter um retrato das experiências vividas pelos informantes e detectar questões relativas à subjetividade de cada um e de todos como unidade familiar. Ficaram claros, então, diversos aspectos concernentes à dinâmica e às relações 
familiares, reflexo da dimensão coletiva familiar a partir da visão individual de cada membro da família, pois é um testemunho que, "bem mais que um documento unilinear, a narrativa da testemunha mostra a complexidade do real. Oferece uma via privilegiada para compreender a articulação dos movimentos da história com a cotidianidade" (BOSI, 2012, 2013, p. 197).

Além do mais, o tom confidencial desse tipo de técnica faz com que o informante expresse pensamentos muitas vezes reprimidos, pontuando também "marcas e marcos de sua vida" (LOPES, BORELLI e RESENDE, 2002, p. 59).

História de vida cultural (HC)

A técnica de história de vida cultural também é uma entrevista não estruturada e aberta que permite maior liberdade ao entrevistado ao responder. E assim como na entrevista de $\mathrm{HV}$, nesta também elaboramos temas guias para orientar sobre o que gostaríamos que os informantes respondessem. Propusemos então que discorressem sobre aspectos da sua história com as culturas letrada, oral, musical, artística, midiática, tecnológica e de lazer.

Esta técnica foi proposta por Martín-Barbero em um colóquio em que discutiu com as autoras do livro inspiração o projeto de pesquisa Vivendo. Para a nossa pesquisa, também foi importante para recuperar a história dos informantes com os diferentes meios e porque a prática do consumo é uma experiência cultural que perpassa também o cotidiano por meio dos hábitos e usos que cada receptor faz dos produtos culturais. Então, a história de vida cultural permitiu que identificássemos "os lugares de onde procedem as inscrições do 'palimpsesto do receptor'. E mais, permite pensar esse emaranhado de meios que se replicam e reenviam uns aos outros, ao longo dos tempos vividos pelos sujeitos [...]" (LOPES, BORELLI e RESENDE, 2002, p. 60, grifo das autoras).

Isto posto, as quatro técnicas foram utilizadas com todos os cinco membros das duas familias informantes e foram todas gravadas por meio de um aplicativo de gravação do telefone celular da pesquisadora. Elas serviram para complementar as técnicas de observação etnográfica $(\mathrm{OE})$, observação on-line $(\mathrm{OO})$ e grupo de discussão (GD), apesar de ressaltarmos que todas as técnicas, de certa forma, se auto complementaram. 
Observação etnográfica (OE)

A observação etnográfica foi utilizada para observarmos a assistência da telenovela com os receptores em seu ambiente doméstico e ainda todas as práticas que envolvem tal recepção aliadas à observação do cotidiano familiar dos informantes. $\mathrm{O}$ que fizemos então foi uma "etnografia crítica da recepção", proposta por Ronsini (2010, p. 2), que é:

a) o conhecimento construído a partir da descrição do contexto espacial e temporal que determina a apropriação dos meios de comunicação, isto é, a apreensão do sentido possível que os atores sociais dão às práticas sociais e culturais produzidas na relação com os meios de comunicação tecnológicos; b) a etnografia é crítica porque visa revelar e compreender a reprodução social e não apenas a capacidade criativa das audiências em resistir à dominação.

A etnografia é advinda da Antropologia e consiste em "uma concepção e prática de conhecimento que busca compreender os fenômenos sociais da perspectiva de seus membros (entendidos como 'atores', 'agentes', 'sujeitos sociais')" (GUBER, 2001, p. 12, grifos da autora, tradução nossa) ${ }^{54}$. Assim, estivemos no universo dos investigados, no espaço doméstico, ou seja, no contexto onde as coisas acontecem para poder apreender com maior profundidade o que estudamos. Foi possível captar os rituais domésticos e principalmente os sentidos que esses rituais têm para os informantes. Porém, com essa técnica, não se deve captar apenas o conteúdo das mensagens que são vistas pelos receptores, mas também os esquemas que permeiam a leitura dessas mensagens, a maneira como a rotina das pessoas se integra ao que está sendo mostrado pela mídia, nesse caso, pela telenovela. No momento da OE, os aspectos relevantes para a pesquisa são as reações dos informantes, o que os faz rir, chorar e até ficar brabos (LINDLOF; TAYLOR, 2011; SIFUENTES, 2014). Analisamos também as rotinas familiares, a infraestrutura da moradia, a distribuição dos objetos e meios de comunicação nas casas.

Utilizamos, nesse momento da pesquisa, a principal ferramenta de coleta de dados da etnografia, o diário de campo. Nele foi anotado tudo o que nos pareceu pertinente com relação à vivência no campo, pois o diário é o local onde "o investigador consigna

\footnotetext{
${ }^{54}$ No original: "una concepción y prática de conocimiento que busca compreender los fenómenos sociales desde la perspectiva de sus membros (entendidos como 'actores', 'agentes', o 'sujetos sociales')".
} 
minuciosamente cada detalhe observado, para assim poder dar conta dos detalhes importantes e as mudanças de significados que vai percebendo, sem perder o fio dos feitos" (OROZCO; GONZÁLEZ, 2011, p. 151, tradução nossa) ${ }^{55}$.

As mediações socialidade e ritualidade foram analisadas durante a OE, pois dizem respeito exatamente às relações sociais estabelecidas no cotidiano e práticas e rituais de assistência da telenovela.

A observação etnográfica foi organizada da seguinte maneira: a pesquisadora assistia com cada família um capítulo da telenovela por semana, em um sistema de revezamento. Isto aconteceu ao longo dos 6 meses em que a telenovela corpus da pesquisa foi ao ar. $\mathrm{O}$ esquema de visitas semanais só não era cumprido devido à eventuais falta de disponibilidade dos receptores. O revezamento também aconteceu para que fosse possível acompanhar dois capítulos essenciais da trama com as duas famílias estudadas, assim, o primeiro capítulo foi assistido com a Família 1 e o último com a Familia $2^{56}$. Na maioria das vezes, a observação iniciava antes do começo do capítulo da telenovela, visto que a pesquisadora chegava mais cedo, quando os informantes podiam recebê-la para fazer as entrevistas. Nos finais de semana, em outros horários que a telenovela não estivesse ao ar, foram feitas visitas, não só para complementar as observações feitas durante a etnografia, mas também para estreitar a relação entre pesquisador-pesquisado.

Observação on-line (OO)

Diferente de todas as outras técnicas aplicadas na pesquisa e que também estavam no Vivendo, a de observação on-line foi acrescentada para suprir a demanda proposta pela transmidiação. Esta técnica complementou o que vimos com a observação etnográfica. Por meio dela, averiguamos se os receptores iam ao ambiente transmídia enquanto assistiam a telenovela (isto foi percebido com melhor clareza na OE, pois, quando estávamos com os informantes, podíamos apreender a assistência como um todo), o que faziam nele e ainda se continuavam repercutindo e interagindo com a trama em suas redes sociais na internet em outros momentos. Ainda analisamos, mais uma

\footnotetext{
55 No original: "el investigador consigna minuciosamente cada detalle observado, para de este modo poder dar cuenta de los detalles importantes y los câmbios de significados que va percibiendo, sin perder el hilo de los hechos".

${ }^{56}$ É assim que iremos nos referir às famílias informantes desta pesquisa.
} 
vez, as mediações socialidade e ritualidade também no que diz respeito à importância e ao espaço que o digital (por meio das redes sociais, especialmente) tem durante a assistência da telenovela.

A nova especificidade e possibilidade de pesquisa também no espaço virtual dá margem para uma série de reflexões acerca da melhor maneira de estudar essa complexidade composta por espaços múltiplos e fragmentados. A tentativa foi de ver o que está entre os polos de comunicação (PRIMO, 2013). Lopes (2010, p. 420) ressalta 10 pistas que devem ser levadas em consideração em uma investigação que contemple essa nova ambiência:

\begin{abstract}
a pesquisa virtual supõe problematizar o uso da internet como objeto inserido na vida das pessoas e como lugar de estabelecimento de comunidades; 2) os meios interativos como a internet devem ser entendidos simultaneamente como cultura e como artefato cultural; 3 ) pensar a pesquisa na rede como fluida, dinâmica e móvel; 4) reconsiderar a noção de campo de estudo para não centrar os fluxos e conexões em nenhum lugar localizado ou limitado; 5) o desafio da pesquisa virtual está em examinar como se configuram os limites e as conexões entre o "virtual" e o "real"; 6) devido ao deslocamento temporal, a imersão no contexto se dá de forma intermitente; 7) a pesquisa virtual é parcial, não é totalizante; 8) a reflexividade metodológica outorga protagonismo à relação entre pesquisador e tecnologia; 9) a validade de todas as formas de interação mediadas pela tecnologia para constituir o objeto de estudo; 10) adaptabilidade permanente aos objetivos da pesquisa.
\end{abstract}

Para tornar possível a observação on-line todas as redes sociais de todos os informantes foram adicionadas às redes sociais da pesquisadora, sendo elas: Facebook, Instagram, Twitter e WhatsApp. A única rede social utilizada por parte dos informantes (duas da Família 1) que não pôde ser observada, mas que também não teria razão para ser, foi a rede de relacionamento Tinder. Não eram feitas interações com os perfis dos informantes, estas aconteciam apenas pela rede WhatsApp para agendar as visitas. A opção por não interagir se deu pelo fato que de, a pesquisadora não tinha a intenção de constranger os receptores em suas redes ou deixá-los com a sensação de que estavam sendo "vigiados" o tempo inteiro. Então, observar de forma quase que invisível possibilitou que os informantes pudessem agir da maneira mais natural possível em suas redes, mesmo sabendo que, por ter a pesquisa adicionada, poderiam sentir-se observados. Assim, foi realizado um acompanhamento das postagens e interações a fim de detectar as atividades relativas à telenovela no ambiente digital e ainda analisar 
aspectos das suas socialidades e a relação com as tecnicidades neste local. Essa observação não aconteceu de forma estruturada, mas além de analisar as redes dos informantes no horário em que a telenovela estava sendo veiculada, foram feitas visitas nesses espaços virtuais dos informantes, pelo menos, duas vezes na semana.

Grupo de discussão (GD) e Telenovela reeditada (TVN-R)

O grupo de discussão é uma técnica que consiste numa entrevista coletiva e não estruturada que teve por objetivo estimular a discussão sobre a telenovela reeditada com as cenas escolhidas pelos próprios receptores. O papel da pesquisadora foi apenas de moderadora, deixando o grupo debater sobre suas próprias interpretações (LOPES, BORELLI e RESENDE, 2002), e ainda sobre os comentários e pontos de vista acerca de suas experiências e as dos outros membros do grupo (BAUER \& GASKELL, 2002). Lopes, Borelli e Resende (2002) citam Alasuutari (1995) para ressaltar que a técnica é profícua porque abrange diversos ângulos, produzindo, assim, uma variedade de discursos sobre o mesmo tema.

Desta forma, o GD foi a última técnica a ser aplicada na pesquisa de campo, acontecendo depois que a telenovela já tinha terminado. Isto aconteceu para que os receptores pudessem escolher quaisquer cenas da trama, além de já terem uma visão global desta pelo fato de já ter sido encerrada.

Assim como com as outras técnicas, a dinâmica do GD ocorreu em cada família separadamente. Todos os membros de cada uma sentaram juntos e assistiram ao vídeo editado com as cenas da telenovela O Sétimo Guardião (Globo, 2018-2019) escolhidas por eles em um outro momento como as mais marcantes. $O$ grupo de discussão a partir da telenovela reeditada foi uma estratégia usada em que o estímulo não partiu da pesquisadora e sim da telenovela ressignificada pela memória dos receptores.

O exame da telenovela reeditada foi feito articulando as questões técnicas da produção das cenas bem como aspectos textuais e de roteiro com o que foi dito no grupo de discussão. Porém, ressaltamos que a intenção aqui não foi fazer uma análise audiovisual, mas pontuar aspectos relevantes da produção que dialoguem com a nossa proposta de pesquisa. 
Devido ao volume de material gerado pela pesquisa empírica, os dados coletados através de todas estas técnicas recém explicitadas, com exceção das observações etnográficas e on-line, foram tabulados no software Maxqda Analytics Pro 2018. Optamos por um software diferente do utilizado no livro inspiração por este ser mais atual e porque supriria todas as demandas da pesquisa de uma forma satisfatória.

$\mathrm{O}$ uso de software em uma pesquisa qualitativa "funciona como instrumento para mecanizar tarefas de organização e arquivamento de textos, que facilitam o tratamento de dados" (FREIRE, 2015, p. 97). Segundo Bardin (2009), o desenvolvimento de ontologias para software proporcionou a definição do que são objetos, classes (coleções, conjuntos, etc.) e atributos ou códigos (parâmetros, características ou categorias para os objetos de análise) e as mais variadas relações entre esses objetos conforme as demandas de cada pesquisa. O Maxqda permitiu que pudéssemos tabular os dados e desenvolver inúmeras conexões entre eles. Guetterman, Creswell e Kuckartz (2015, p. 147, tradução nossa) pontuam a utilidade do programa:

[...] software alemão Maxqda (versão 11), que possui uma coleção de recursos de métodos mistos. Esses recursos facilitam a integração de dados qualitativos e quantitativos. Além disso, eles fornecem ferramentas para o pesquisador criar tabelas e figuras para representar a integração visualmente aos leitores ${ }^{57}$.

Antes de começarmos a utilizar o programa, foram transcritas todas as técnicas aplicadas no campo (QC, EG, HV, HC,GD), com exceção das duas técnicas de observação que demandaram a análise mecânica do diário de campo da pesquisadora bem como a memória do visto e vivido com as familias. Afinal, estas duas técnicas não são estruturadas e por isso não se tem como transcrever o que já foi escrito pela investigadora. Então, as outras cinco técnicas gravadas foram transcritas manualmente, e de maneira literal, a fim de que não ficassem de fora nada do que foi dito pelos informantes, pontuando inclusive o que não foi dito, como os momentos de silêncio, risos, olhos marejados e constrangimento. No total, foram transcritas 13 horas de entrevistas.

\footnotetext{
57 No original: [...] german software Maxqda (version 11), wich has a collection of mixed methods features. These features facilitate the integration of qualitative and quantitative data. Furthermore, they give the researcher tools to create tables and figures to represent the integration visually for readers.
} 
Após essa etapa, todos os documentos transcritos foram exportados para o Maxqda e dispostos em duas pastas diferentes de modo que cada família tivesse sua pasta de arquivos com os respectivos membros. Em seguida a análise foi operacionalizada, ou seja, foram criados grandes conjuntos denominados com as quatro principais mediações (temporalidades, espacialidades, sensorialidades e tecnicidades) e, dentro desses conjuntos, criamos as categorias analíticas empíricas. Este processo de categorização partiu dos pressupostos teóricos que norteiam nossa pesquisa de acordo com as mediações e também dos próprios dados coletados em campo em um "processo lógico dedutivo/indutivo" (LOPES, BORELLI e RESENDE, 2002, p. 67).

Desta forma, temos tal organização na plataforma do programa conforme os conjuntos e categorias analíticas empíricas:

- Temporalidades: cotidiano familiar, infância, relações amorosas, relações interpessoais, emprego;

- Sensorialidades: cidadania, pertencimento de classe (com a subcategoria: distinção), emoção, geracional;

- Espacialidades: assistência, refeições;

- Tecnicidades: econômico, relação com a telenovela, religião, geração, consumo de mídia (com as subcategorias Twitter, Instagram e Facebook), roteiro, lazer, relações de gênero, política, educação, relações familiares, trabalho, sexualidade e técnica. 
Figura 18: Foto da interface do software Maxda Analytics Pro 2018 com nossa

\section{pesquisa}

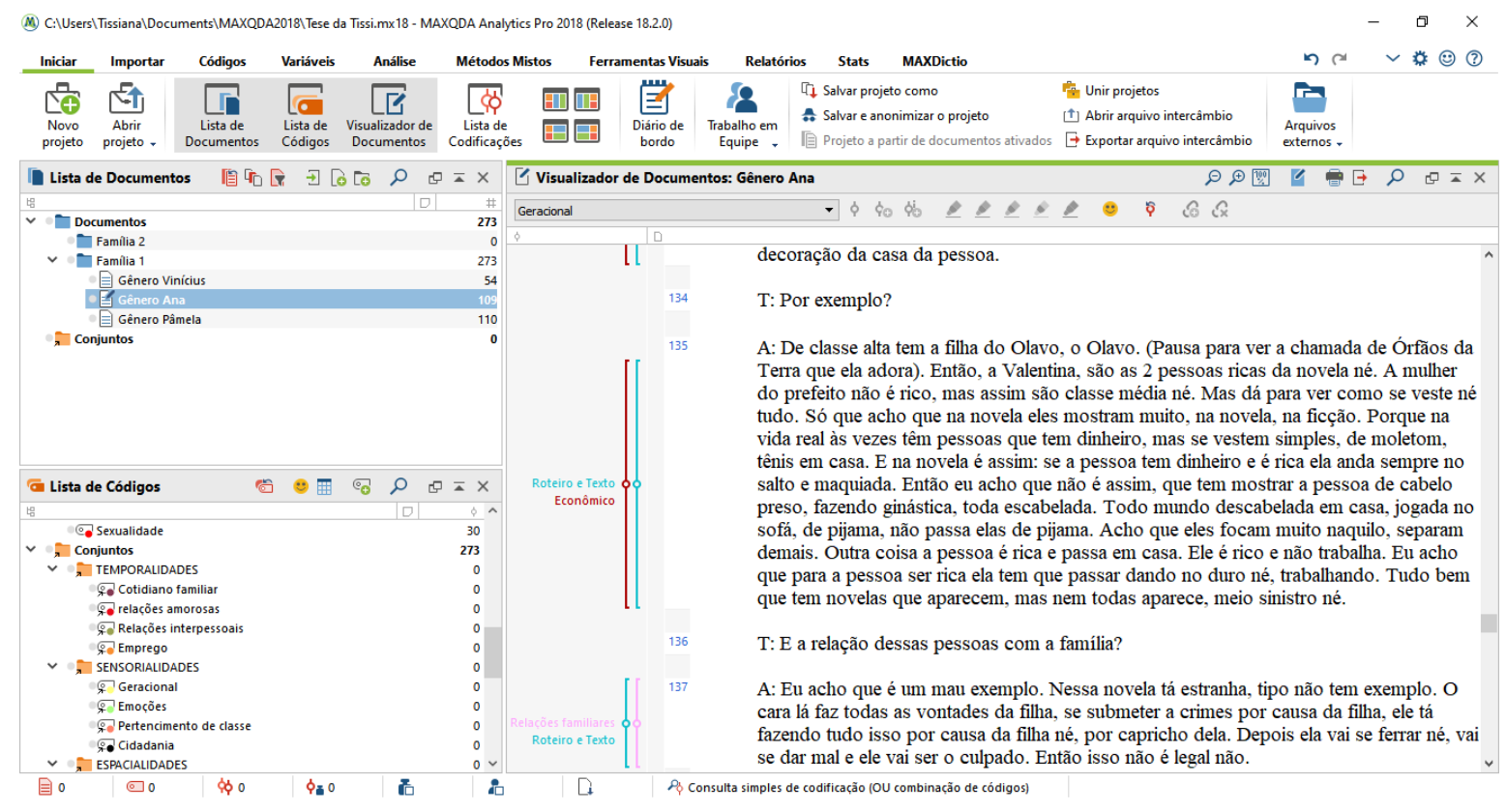

Fonte: Print screen feito pela autora

Algumas categorias se repetem, mas a título de organização dentro do software, tivemos que nomeá-las com sinônimos para evitar que o programa contabilizasse as repetições de maneira errônea.

\subsubsection{Composição da amostra}

A amostragem é utilizada nas pesquisas empíricas para delimitar "o universo de investigação" (LOPES, 2014, p. 144). A nossa amostra é não probabilística, de representatividade social e não estatística (LOPES, 2014), visto que realizamos uma pesquisa qualitativa. A composição da amostra foi baseada nos pressupostos teóricos e metodológicos da nossa pesquisa já explicitados nos capítulos anteriores. Desta forma, a amostra foi elaborada a fim de contemplar uma família de classe média alta e outra de classe média baixa. Optamos por trabalhar apenas com duas familias, em vez de quatro, como em Vivendo, pelo fato de que a pesquisa de Lopes, Borelli e Resende (2002) foi realizada por um grupo de 15 pesquisadores, e esta tese, apenas por uma, sendo então impossível realizar uma investigação com quatro familias. A escolha por trabalhar com as frações de classe média baixa e média alta deveu-se porque, primeiro, no Vivendo, a familia de classe média baixa foi a que estabeleceu uma relação de pesquisa 
(investigador/informante) mais densa (LOPES, BORELLI e RESENDE, 2002). Segundo, elegemos a de classe média alta, porque, entre as frações mais altas, foi a que teve uma relação de maior intensidade com a pesquisa do livro inspiração. Além do que, se levarmos em consideração a pirâmide de estratificação social, ambas são, a título de comparação, correspondentes.

De acordo com o que já explicitamos no capítulo 4, em que discutimos nosso entendimento sobre classe social, o conceito é complexo e envolve questões para além do econômico. Mas uma pesquisa empírica como a nossa precisa ser operacionalizada, portanto tivemos que adotar um critério de classificação de classes sociais. O objetivo com isso foi de avançar acerca do que foi feito no nosso livro inspiração, em que a classificação seguiu uma tipologia de bairros. As familias foram classificadas por "favelada, periferia, bairro de classe média e condomínio fechado de classe média alta" (Ibdem, p. 46). Levamos em conta o local em que moram, mas sentimos a necessidade de adotar um critério de classificação que considerasse outras dimensões.

Portanto, adotamos o critério da ocupação do membro mais bem situado, de Quadros, Gimenez e Antunes (2013), em que, embora os rendimentos dos agentes variem, existe um padrão médio de estilo de vida conforme esta ocupação, além de considerar os aspectos educacionais. Costa (2013) afirma que o trabalho condiciona a posição social não apenas por agregar a renda, mas também a segurança e as condições de vida dos trabalhadores.

Organizar a nossa amostra por ocupações também dialoga com a configuração proposta por Wrigth (1997), que parte da relação com os meios de produção proposta por Marx. Mas ele complexifica esta relação quando destaca as posições de classe conforme a articulação da propriedade dos meios de produção (empregadores e autoempregados) e o trabalho (assalariado baseado na existência ou não de habilidades e autoridade). O critério ocupacional tem relevância porque indica fatores importantes relativos às relações sociais, associados às expectativas e demandas da vida dos agentes e interferindo no que diz respeito a status, prestígio e relações de poder (QUADROS e MAIA, 2010). Segundo Durkheim (1984), pertencer a um grupo profissional indica a posição de um ator na estrutura social.

Logo, certas ocupações são tidas como típicas das classes altas e outras das classes baixas ou populares: 
A alta classe média - o topo da estrutura social, dado que as pesquisas não captam adequadamente a representação social dos ricos - inclui ocupações típicas, definidas aprioristicamente, inspiradas no sociólogo americano Wright Mills. São médicos, professores do ensino superior, engenheiros, empresários etc. (QUADROS, GIMENEZ e ANTUNES, 2013, p. 2).

A ocupação é a base para a inclusão de um agente em sociedades como a brasileira, além do que, "depois da propriedade, é a base da desigualdade social; portanto, a geração de bons empregos é fundamental para o desenvolvimento social" (Ibdem, p. 6).

Sobre a nossa amostra ser composta por familias, a primeira razão é que assim foi feita a investigação em Vivendo, e a segunda se deve ao fato de que a família é constituinte importante da socialidade das pessoas, já que é o primeiro lugar "de construção de habitus e do gosto. Sendo assim, a dinâmica familiar é de importância fundamental para entender as diferentes apropriações/construções de sentido [...]" (LOPES; BORELLI; RESENDE, 2002, p. 46, grifo das autoras). Os valores, a ética e a moral que conformam a visão de mundo social dos informantes são também, certamente, elaborados e transmitidos pela familia. Sendo assim, a família funciona “como referência simbólica". Além do que, “[...] a tradição não se transmite pelo sangue, pelo ar nem por picada de mosquito. São instituições concretas- a família, a escola, o trabalho, etc. - que nos fazem o que somos" (SOUZA, 2018, p. 74).

Dito isto, nossa amostra é composta por uma família de classe média baixa, que chamamos de Familia 1, constituída por quatro pessoas de diferentes idades e profissões e moradores do bairro Jardim Martinica, no distrito de Campo Limpo, na Zona Sul de São Paulo. A outra família, que é de classe média alta e chamamos de Família 2, é constituída por duas pessoas de diferentes idades, moradores do bairro Sumaré, localizado na Zona Oeste de São Paulo, no distrito de Perdizes. Detalharemos mais sobre as famílias no capítulo 6 durante a nossa análise. O parâmetro de escolha das famílias foi pertencerem às classes sociais que iríamos investigar, assistir à telenovela das $21 \mathrm{~h}$ da Globo, e, é claro a disponibilidade em participar de uma pesquisa tão longa como a nossa. 


\subsubsection{O corpus da pesquisa}

O corpus de uma pesquisa é a "coleção finita de materiais, determinada de antemão pelo analista, com (inevitável) arbitrariedade, e com a qual ele irá trabalhar" (BARTHES, 1967, p. 96). O nosso corpus é formado pelos 161 capítulos da telenovela das 21 horas O Sétimo Guardião (Globo, 2018-2019). Para ter acesso irrestrito e ilimitado a todos os capítulos, assinamos a Globoplay, plataforma digital com streaming de vídeos sob demanda criada e desenvolvida pelo Grupo Globo. A assinatura serviu para que a pesquisadora pudesse assistir a algum capítulo que eventualmente não tenha assistido, consultar alguma cena mencionada pelos informantes durante a pesquisa de campo e ainda para que fosse possível realizar o download das cenas escolhidas pelos receptores como suas preferidas e reeditá-las para a dinâmica do grupo de discussão já mencionada.

Portanto, estas cenas tidas como mais marcantes na concepção dos receptores foram reeditadas na sequência em que foram escolhidas por eles, constituindo, assim, duas outras telenovelas, cada uma produzida por uma família. Elas foram assistidas com os informantes durante o grupo de discussão.

Mesmo tendo acesso aos capítulos através do Globoplay, a pesquisadora assistiu a maioria dos capítulos da telenovela diariamente quando eram veiculados na Globo, salvo poucas exceções. Esta assistência era acompanhada de um caderno onde eram realizadas anotações sobre o capítulo assistido.

Ainda fazem parte do corpus da pesquisa a sinopse da telenovela disponibilizada pelo Gshow do site Globo.com ${ }^{58}$ e um clipping com notícias e conteúdos sobre a trama coletado pela autora com o objetivo de complementar a análise acerca das questões de produção da telenovela.

\subsection{Percursos e percalços da pesquisa empírica: uma reflexão}

Ao longo de todo o nosso texto, utilizamos a primeira pessoa do plural por entendermos que o estudo não é um produto de esforço individual, uma vez que é construído pela autora e sua orientadora. Porém, a partir de agora, em algumas partes

\footnotetext{
${ }^{58}$ Disponível em: https://gshow.globo.com/novelas/o-setimo-guardiao/noticia/o-setimo-guardiao-entendaa-trama-da-proxima-novela-das-9.ghtml Acesso em novembro de 2018.
} 
deste tópico e nos próximos capítulos, será empregada a primeira pessoa do singular porque a pesquisa de campo é um momento individual em que, obviamente, é carregado de contribuições coletivas, mas que inevitavelmente, a pesquisadora está/esteve sozinha.

A reflexão aqui se faz necessária devido à ininterrupta vigilância epistemológica de "ver" com método que nos propomos ter ao longo de toda a pesquisa, pois, as escolhas, o percurso e até os percalços acontecem porque o pesquisador não é neutro. A ruptura epistemológica acontece justamente na experiência da pesquisa de campo "em que são relativizados, simultaneamente, o senso comum do informante e o ponto de vista científico do pesquisador, tentando assim abarcar todas as marcas de etnocentrismo, inclusive científico" (LOPES, 2010b, p. 37). Assim, é possível evitar "o vício teoricista de pressupor a passividade do objeto de investigação [...] e o vício etnocêntrico de confundir o desejo sobre o que a realidade deve ser" (Ibdem).

Há, então, a necessidade de desnaturalização do trabalho de campo e de entender que este é formado por "situações de comunicação" que implicam relações dinâmicas entre os autores envolvidos, ou seja, pesquisador e pesquisado, e que estas configuram processos de negociação, colaboração e resistência, assim, "a reflexividade, que é sinônimo de método, permite perceber e controlar no campo a própria condução de uma entrevista [...]" (LOPES, 2010b, p. 44). Não é possível explorar a relação de comunicação na sua generalidade sem se deter nos problemas práticos e teóricos desta interação, uma vez que, essa relação é uma "relação social" que exerce efeitos sobre os resultados obtidos e só a reflexividade (método) é capaz de permitir que se perceba e se controle no campo a "própria condução da entrevista, os efeitos da estrutura social na qual ela se realiza" (BOURDIEU, 1997, p. 694). Para o autor, quando o investigador tenta saber o que se faz no início de uma relação de entrevista é, antes de tudo, tentar conhecer os efeitos que podem ser produzidos:

[...] sem o saber por esta espécie de intrusão sempre um pouco arbitrária que está no princípio da troca [...] é tentar esclarecer o sentido que o pesquisado se faz da situação, da pesquisa em geral, da relação particular na qual ela se estabelece (Ibdem, p. 695, grifo do autor). 
É a capacidade de mensurar a amplitude e a natureza da distância que existe entre a finalidade da pesquisa tal como é percebida pelo investigado e o objetivo do pesquisador que pode, pelo menos, tentar reduzir as distorções que dela são resultantes. Assim, é o pesquisador que inicia o jogo e que estabelece as regras deste sem negociação prévia com o pesquisado, o que redobra o abismo social já existente pelo fato do pesquisador já ocupar uma situação superior ao entrevistado, principalmente devido aos seus capitais culturais diferentes. Esses efeitos, Bourdieu (1997) também chama de "violência simbólica" e, para esta ser minimizada, é preciso que aconteça uma relação efetiva de escuta e também metódica. A proximidade social e a familiaridade asseguram, conforme o autor, as condições essenciais de uma comunicação "não violenta" na pesquisa de campo.

Porém, os procedimentos para reduzir estas distâncias entre o investigador e investigado têm seus limites, já que, quando nada neutraliza ou suspende

[...] os efeitos sociais da dissimetria ligada à distância social, não se pode esperar conseguir obter declarações tão pouco marcadas quanto possível pelos efeitos da situação de pesquisa senão ao preço de um trabalho incessante de construção (Ibdem, p. 699).

Todavia, o pesquisador não deve fingir e nem tentar anular a distância social que o separa do pesquisado, mas ser capaz de se colocar no lugar do outro (do pesquisado) em pensamento. Isto é, como já referido no capítulo 2, "ver com os outros" (MARTÍNBARBERO e CORONA BERKIN, 2017) em uma situação de pesquisa horizontal em que um acaba por se reconhecer pelo olhar do outro. Mas isso não quer dizer passar para o lado do outro, transformar-se em um deles, e sim, escutar o outro para poder interpretá-lo, ser empático.

A questão é que, em conformidade com Bourdieu (1997), não devemos acreditar que apenas pela reflexividade o investigador possa controlar todos os efeitos complexos e diversos da relação de pesquisa, pois os pesquisados podem intervir, tanto consciente quanto inconscientemente, para tentar impor a sua própria definição da situação. Afinal, nesta relação de entrevista, de troca, cada um (pesquisado e pesquisador) "engana um pouco o outro ao se enganar a si próprio" (Ibdem, p. 703). 
Tal reflexão epistemológica foi essencial para a pesquisa como um todo, mas especialmente, na pesquisa de campo. Temos consciência da imprescindível contribuição das investigações que vão a campo "privilegiando assim a 'visão de mundo' de pessoas de carne e osso, fornecem uma perspectiva molecular 'de baixo', por assim dizer, dos acontecimentos" (FONSECA, 2004, p. 213, grifos da autora). Mas o fascinante ato de "sujar as mãos nas cozinhas da pesquisa empírica" (BOURDIEU e WACQUANT, 1992, tradução nossa) ${ }^{59}$ também nos coloca diante de situações não esperadas.

Pontuo primeiramente que, encontrar as duas famílias que fariam parte da amostra foi uma tarefa bastante árdua, visto que eu não morava na imensa São Paulo há muito tempo e meu círculo de pessoas era limitado para que pudesse conhecer as famílias que se enquadrassem nos critérios da pesquisa. Imediatamente comparei com quando realizei a pesquisa de mestrado em Santa Maria, no interior do Rio Grande do Sul, lugar em que nasci e vivi a maior parte da minha vida. Lá, encontrar as três familias de classe popular que fizeram parte da pesquisa de recepção sobre telejornal foi muito fácil. Então, voltamos à pesquisa de doutorado em São Paulo. Depois de inúmeras tentativas das mais variadas formas, por meio da secretaria de uma igreja e depois de semanas de espera, consegui a confirmação de que uma família de classe média baixa constituída por sete pessoas estaria disposta a participar da pesquisa. Coincidentemente, tal família era moradora do mesmo bairro em que morava a família de classe média baixa que participou do Vivendo. Os primeiros contatos foram proveitosos, mas uma semana antes a mãe da familia entrou em contato para avisar que estavam desistindo da participação porque o marido preferia que a família assistisse a telenovela do SBT em vez da trama da Globo que iria iniciar em breve. Diante disso, contagem regressiva para encontrar outra família. Mais uma vez depois de diversas tentativas, em uma conversa no salão de beleza que frequento, encontro, em uma manicure, a família que iria fazer parte da amostra.

Conseguir a familia de classe média alta igualmente exigiu esforço, e após também diversas tentativas, consegui que uma amiga de um vizinho meu aceitasse participar da pesquisa.

\footnotetext{
${ }^{59}$ No original: "to dirty its hands in the kitchens of empirical research".
} 
No que diz respeito ao campo em si, os percalços se deram com algumas diferenças em cada família. Na Família 1, por exemplo, havia um certo contratempo para ajustar horários das informantes com a pesquisa porque, como será pontuado no capítulo seguinte, ambas têm longa jornada de trabalho que muitas vezes inclui as noites e os finais de semana e essa situação fazia com que, algumas vezes, as informantes preferissem, compreensivelmente, de tempos de lazer/descanso em detrimento da minha visita. Na mesma familia, houve fraca adesão dos jovens, um deles porque trabalha durante o dia e estuda à noite e, assim como as duas outras integrantes da familia, tinha pouco tempo de lazer/descanso e, quando tinha e eu estava lá, ele preferia ficar no seu quarto. Além do mais, é um jovem tímido. O segundo jovem membro desta família participou mais ativamente da pesquisa, mas também em alguns momentos não estava em casa, ou por estar com o pai (que é separado da mãe), ou por estar jogando futebol com os amigos. Porém, no final da pesquisa, ele, que está no auge da sua préadolescência, arranjou uma "namoradinha" e preferia estar no quarto falando com ela no WhatsApp a estar na sala assistindo à telenovela com a gente. Ele, inclusive, não participou do grupo de discussão realizado com a família após o final da telenovela.

$\mathrm{Na}$ Familia 2, também houve necessidade de ajustamento de horário das informantes devido a compromissos de trabalho ou pelo fato de, algumas vezes, a jovem não estar em casa, ou por estar com o pai (que também é separado da mãe), ou com os amigos no cinema, no shopping ou em algum show. Porém isto aconteceu de forma menos acentuada que na Família 1. Com relação à jovem, ela aderiu com maior densidade à pesquisa em comparação aos jovens da Familia 2, talvez por ser mais velha e menos tímida. Apesar de que, muitas vezes, tive que me esforçar para manter o seu interesse em minhas perguntas ou nossas conversas, pois eu competia com o seu telefone celular.

Percebi ainda, nas duas famílias informantes, em alguns momentos, um certo desconforto com a duração da pesquisa, pois, perguntas do tipo: "Ah mas é até o final da novela mesmo?" ou "Você não quer fazer todas as entrevistas logo, para terminarmos de uma vez?" 60 eram feitas pelos informantes. Este certo desconforto e a necessidade de ajustamento dos horários parece-me que aconteceram porque, entre

\footnotetext{
${ }^{60}$ As formas de expressão verbal usadas pelos informantes foram mantidas e por isso est arão transcritas ao longo do texto em seu estado literal. Estas aparecerão en tre aspas e em itálico quando forem menores que três linhas ou apenas emitálico quando forem superiores a três linhas.
} 
outras questões relacionadas aos capitais econômico, cultural e social dos informantes, está a questão do tempo. Ficou claro para mim, em comparação com o vivido em uma pesquisa de campo em Santa Maria, que o tempo do relógio em São Paulo é diferente. Aqui, o tempo passa mais rápido e as pessoas são mais velozes para acompanhar esse tempo. Há sempre algo para fazer, seja com relação ao trabalho ou com relação ao lazer. Quando se chega em casa depois de um dia longo de serviço, ainda há o que se fazer. Já no interior, como no exemplo de Santa Maria, o tempo passa mais devagar, e as pessoas acompanham esse ritmo, porque, ao chegar em casa após a jornada de trabalho, sentam com suas famílias para tomar o tradicional chimarrão ou até mesmo na frente das casas ou nas sacadas para confraternizar com os vizinhos ou então apenas para contemplar a paisagem. Bosi (1987, p. 75) confirma que o tempo do relógio no interior é diferente:

Há casas em cidades tranquilas em que o tempo parou; o relógio das salas é o mesmo que pulsava antigamente e as pessoas que pisam as tábuas largas do assoalho conservam um forte estilo de vida que nos surpreende pela continuidade.

É relevante pontuar que, apesar dos percalços, fui muito bem recebida pelas duas familias ao longo de todos os meses de realização da pesquisa empírica. Degustei cafés, chás, biscoitos e outros lanches com ambas as familias em momentos extremamente agradáveis. Algumas vezes, jantei com a Família 1, e foi com eles, inclusive, que adquiri o hábito de comer coco ao natural. Ainda assim, para que fosse possível analisar e captar a experiência e o cotidiano das familias e a recepção da telenovela, precisei me sentir aceita por elas. Esta aceitação não é aquela que tive desde o instante em que se dispuseram a fazer parte da pesquisa, mas o momento em que começaram a agir de maneira mais natural com a minha presença. Sei que, obviamente, minha presença alterou de alguma maneira sua rotina e seus comportamentos. Mesmo assim, foi importante me sentir cada vez mais próxima deles, cumprindo com a premissa de confiança mútua e intercâmbio indispensáveis em uma pesquisa empírica (LAPLANTINE, 2004). Reitero que sempre fui muito bem acolhida pelas duas familias, o que quero salientar aqui são as situações em que de fato me senti uma estranha familiar. 
Com a Família 1 destaco duas situações: a primeira delas foi quando o filho jovem, que apesar de responder às entrevistas e participar de diversos momentos de assistência conosco, jantou em minha frente, pois ele se sentia constrangido de fazer as refeições na minha presença, quando fosse o caso. Assim, quando foi até o fogão, serviu seu prato e sentou à mesa perto de onde estávamos assistindo a telenovela após chegar de um jogo de futebol, senti-me de fato aceita, principalmente por ele. Ele me olhou, envergonhado, e falou sorrindo: “Ah, não repara que como bastante, viu?”. A partir de então, ele passou a participar das refeições com a família, mesmo com a minha presença. $\mathrm{O}$ outro momento ainda com a mesma família foi quando as duas integrantes passaram a me contar algumas intimidades de seus relacionamentos amorosos e sexuais.

Já com a Familia 2, esse "click" se deu quando a jovem, sozinha comigo, dividiu alguns assuntos privados da relação familiar, e a mãe, em outro momento, também sozinha, ficou com os olhos marejados ao relatar, mesmo que rapidamente, seus problemas, já controlados, de ansiedade e depressão iniciados no processo de separação do pai de sua filha.

Então, pontuar estes percursos e percalços foi um profícuo exercício de vigilância epistemológica e de ruptura que me fez observar a mim mesma como pesquisadora e não apenas as reações dos outros em relação a mim. Desta forma, ressalto a importância de atentarmos para as nossas "próprias reações as reações dos outros" (LAPLANTINE, 2004, p. 27), porque, se isso for alcançado, pode contribuir muito com a nossa pesquisa. 


\section{PARTE II:}

NAVEGANDO COM A TELENOVELA 


\section{Capítulo 6: Nosso universo de pesquisa}

Neste sexto capítulo, apresentamos as duas famílias informantes da pesquisa e suas realidades, pontuando aspectos do modo de vida, suas relações interpessoais, trabalho e todos os outros fatores que são importantes de serem observados para articulação com a recepção da telenovela. No segundo tópico do capítulo, discorremos sobre a telenovela que compõe o corpus da pesquisa, O Sétimo Guardião (Globo, 2018-2019), destacando pontos sobre sua produção relacionados a sinopse, elenco e algumas questões de ordem técnica. Por fim, analisamos as telenovelas reeditadas com as cenas propostas pelos receptores associadas ao grupo de discussão realizado.

\subsection{A realidade das famílias}

Apresentamos agora os quadros e os diagramas que demonstram a composição de cada família informante. Os quadros explicitam os perfis dos integrantes das familias com as principais variáveis individuais de cada membro que constituem o todo familiar. Já os diagramas foram feitos para ilustrar o esquema de parentesco dos integrantes. Eles seguem, respectivamente.

\section{1) Família 1}

\section{Quadro 2: Perfil dos integrantes da Família 1}

\begin{tabular}{|l|l|l|l|l|l|l|}
\hline Nome $^{\text {61 }}$ & Idade & $\begin{array}{l}\text { Local de } \\
\text { Nascimento }\end{array}$ & Escolaridade & Etnia & Religião & Ocupação \\
\hline $\begin{array}{l}\text { Ana (mãe } \\
\text { e irmã) }\end{array}$ & 36 & $\begin{array}{l}\text { Área rural de } \\
\text { Guanambi/BA }\end{array}$ & $\begin{array}{l}\text { Ensino } \\
\text { Médio } \\
\text { Incompleto }\end{array}$ & Negro & $\begin{array}{l}\text { Católica } \\
\text { não } \\
\text { praticante }\end{array}$ & Esteticista \\
\hline $\begin{array}{l}\text { Pâmela } \\
\text { (mãe } \\
\text { irmã) }\end{array}$ & 39 & $\begin{array}{l}\text { Área rural de } \\
\text { Guanambi } \\
\text { /BA }\end{array}$ & $\begin{array}{l}\text { Ensino } \\
\text { Médio } \\
\text { Incompleto }\end{array}$ & Negro & Não tem & $\begin{array}{l}\text { Empregada } \\
\text { doméstica }\end{array}$ \\
\hline $\begin{array}{l}\text { Vinícius } \\
\text { (filho } \\
\text { sobrinho) }\end{array}$ & 12 & São Paulo/SP & $\begin{array}{l}\text { Ensino } \\
\text { Fundamental } \\
\text { em } \\
\text { andamento }\end{array}$ & Pardo & $\begin{array}{l}\text { Católico } \\
\text { não } \\
\text { praticante }\end{array}$ & Estudante \\
\hline $\begin{array}{l}\text { Hugo } \\
\text { (filho } \\
\text { sobrinho) }\end{array}$
\end{tabular}

\footnotetext{
${ }^{61}$ Todos os nomes dos informantes são fictícios para preservar suas identidades.

${ }^{62}$ Hugo não participou ativamente da pesquisa, mas está no quadro porque é integrante da família, pois mora na casa participando então da rotina familiar, contribui com as despesas por já trabalhar, e a mãe (Pâmela) o cita com bastante frequência nas conversas e entrevistas.
} 
Fonte: Elaborado pela autora

\section{Figura 19: Diagrama da Família 1}

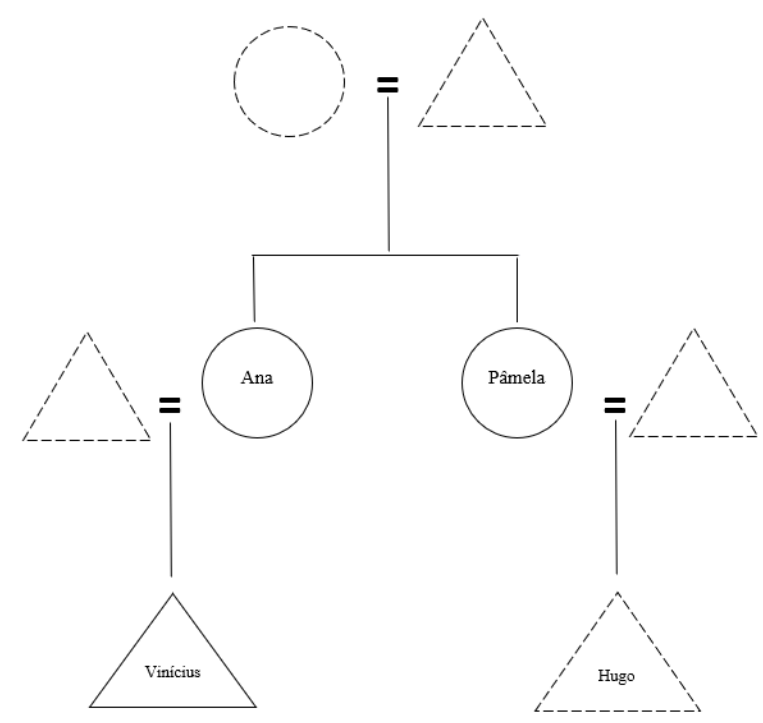

Fonte: Elaborado pela autora

\section{Legenda:}

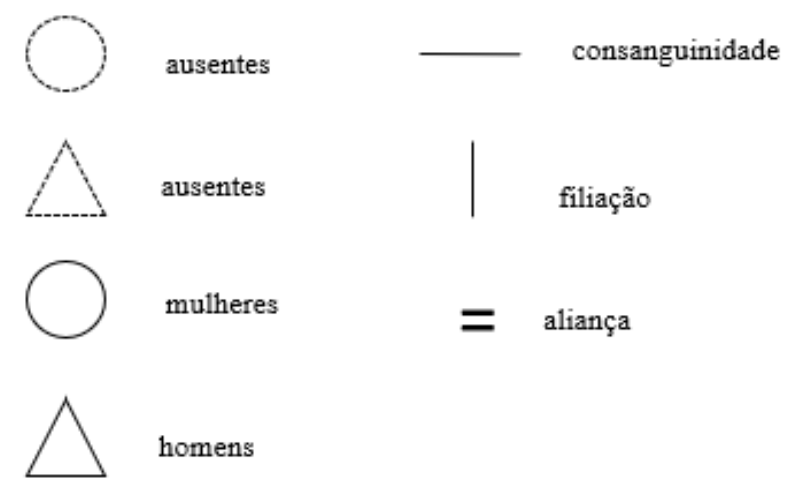

A Familia 1 é composta pelas duas irmãs, Ana (36 anos) e Pâmela (39 anos) e seus respectivos filhos, Vinícius (12 anos) e Hugo (19 anos). Elas moram juntas desde que Ana se separou do marido, há cerca de 2 anos.

Apesar de não se autodeclararem de nenhuma etnia, os integrantes da família possuem fenótipos negro e pardo.

Ana (36) e Vinícius (12) afirmam ser católicos, mas não praticantes, já Pâmela (39) e Hugo (19) não têm religião. Porém toda a familia declara se apoiar na fé e no 
princípio de fazer bem ao próximo, proferidos pela religião, além de usarem a expressão "Graças a Deus" inúmeras vezes em meio a diferentes assuntos.

A família mora no bairro Jardim Martinica, no distrito de Campo Limpo, na Zona Sul de São Paulo. O local é conhecido por abrigar, em sua maioria, moradores migrantes de origem nordestina ${ }^{63}$. A casa, alugada, é de alvenaria, tem aproximadamente $50 \mathrm{~m}^{2}$ e está disposta em um terreno onde tem mais uma construção, a casa de outra familia com que não tivemos contato. Um portão manual de ferro e todo fechado (que não permite nenhum tipo de visão para o interior) é a principal entrada para o terreno. $O$ primeiro que se vê quando o portão é aberto são dois carros: um de Ana (36), um Corsa modelo antigo, e o outro pertence à familia vizinha, que divide o mesmo terreno com os nossos informantes. Para ter acesso à porta principal da casa, é preciso passar por um corredor estreito que leva até esta porta. Ao lado esquerdo dela, fica a área de serviço. Ao entrar, há a cozinha e a sala de estar, conjugadas em um mesmo ambiente. O local possui duas janelas, uma que dá para o corredor de acesso e outra para a área de serviço. O cômodo tem uma pintura verde clara e o chão é todo de piso cerâmico simples na cor bege. Na cozinha há um fogão de quatro bocas, um forno de micro-ondas e uma geladeira, ambos da cor branca. Os móveis da cozinha são bem conservados e dividem espaço com os móveis da sala de estar. A mesa de jantar de madeira com as quatro cadeiras fica encostada em uma parede e coberta por uma tolha de renda. Perto dela, na parede em que fica a janela da sala, está o sofá de dois lugares, antigo (percebi ao sentar), que é coberto por um lençol e fica em frente ao móvel onde está a televisão. O aparelho é de LCD 42 de polegadas, mas não é smart TV e está disposto em uma estante onde estão algumas fotos da família, o aparelho de TV a cabo (a família assina o plano básico) e os troféus de torneios de futebol de Vinícius (12). Há também um aparelho de som. O banheiro é o primeiro cômodo no pequeno corredor que leva para os dois quartos da residência, um para os primos (Vinícius e Hugo) e o outro em que dormem Pâmela (39) e Ana (36). Não tive acesso a nenhum quarto, mas sei que, no quarto das irmãs, há um pequeno aparelho de televisão, mas sem o sinal do cabo.

A sala/cozinha da casa é o espaço de sociabilidade ampliada da familia, é lá que

\footnotetext{
63 Ver

em: https://www.prefeitura.sp.gov.br/cidade/secretarias/cultura/bibliotecas/bibliotecas_bairro/bibliotecas_m_z /marcosrey/index.php?p=5574 e https://www.saopaulobairros.com.br/campo-limpo/ Acesso em fevereiro de 2020 .
} 
recebem as visitas, que são, normalmente, alguns amigos e outros membros da familia que não residem no local, como a mãe, os irmãos e os sobrinhos. Os quartos são os espaços privados, mas o quarto das irmãs também serve para o trabalho, visto que Ana (36), também atende algumas clientes (manicure, pedicure e depilação) em casa, nos seus horários de folga.

Figura 20: Sala com a principal televisão da casa da Família 1

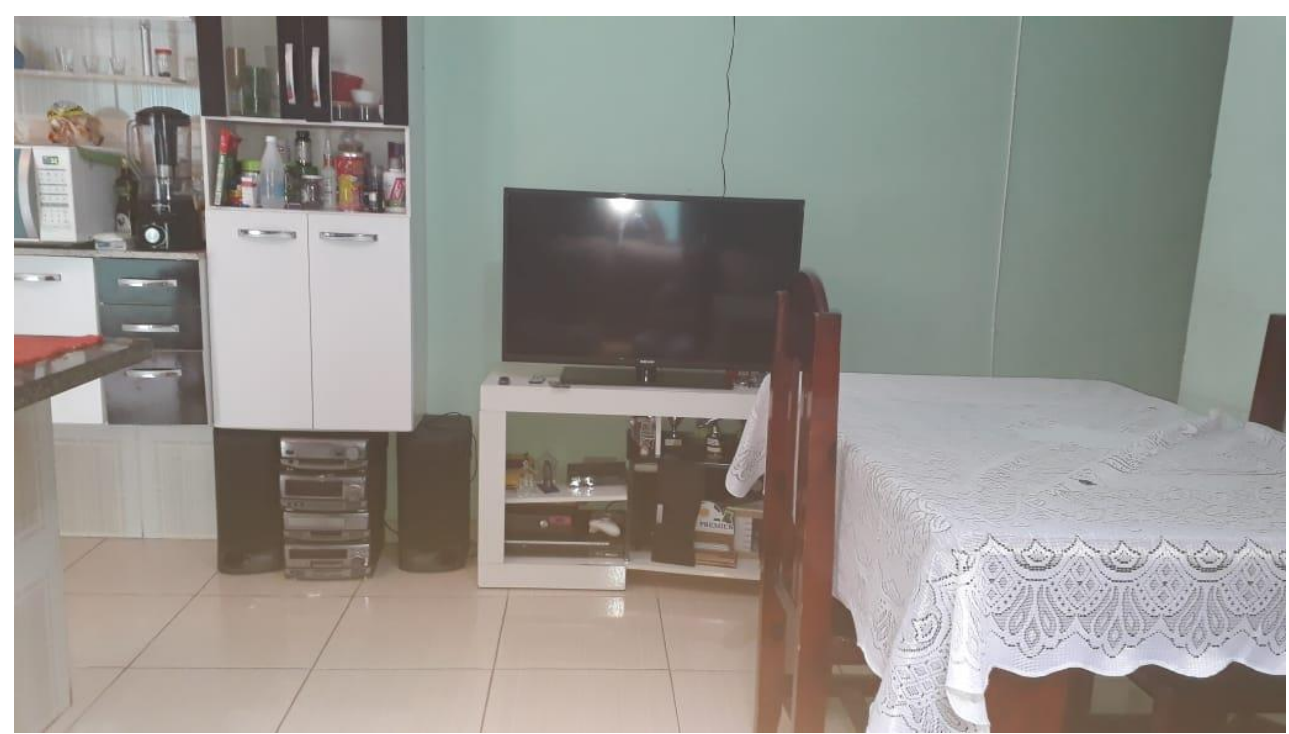

Fonte: Arquivo pessoal da pesquisadora

São Ana (36) e Pâmela (39) que fazem as atividades domésticas da casa, como cozinhar, limpar e organizar. Algumas tarefas são dividas com e entre os meninos, como lavar a louça e arrumar o quarto. Mas as irmãs reclamam que eles são "bagunceiros" e que "jogam um para o outro" as responsabilidades com a casa designadas pelas mães. Segundo Pâmela (39), Hugo (19) justifica que não realiza as tarefas como combinado porque chega em casa muito cansado do trabalho. A mãe diz que até entende, mas repreende o filho: "Mas, e eu, não trabalho? Não chego às 10 horas da noite e não faço as coisas?" (Pâmela, 39).

Pâmela (39) há sete anos é empregada doméstica de um casal de idosos de classe alta que mora na Avenida Paulista. O trabalho é de segunda a sexta-feira, mas, quando há algum almoço ou jantar especial na casa, nos finais de semana, ela também trabalha aos sábados ou domingos. Ela conta que, na casa dos seus patrões, “é tudo na etiqueta”, e a mesa deve ser posta por ela, diariamente, de maneira em que estejam dispostos todos os diferentes e específicos, copos e talheres utilizados durante a refeições: 
Tenho que colocar na mesa de jantar, não tem essa de jantar na cozinha, tem que ser na mesa de jantar. Só o café da manhã que eles tomam na mesa da cozinha, que é do tamanho dessa, não é uma mesinha. Mas, na hora do almoço tem que ser na mesa grande que tem 12 lugares. A toalha tem que tá impecável, tudo tem que tá impecável...nada fora do lugar. Primeiro vai a salada, aí eu retiro tudo da salada e levo o almoço, aí eu não posso levar a sobremesa se tiver um prato na mesa. Eu tenho que retirar tudo da mesa, só deixar o copo de água e levar a sobremesa (Pâmela, 39).

A mulher ainda faz alguns "bicos" de diarista nos horários e dias de folga para complementar a renda da família. E, à noite, estuda em uma escola técnica de formação de cabelereiros, o que faz com que, na maioria das noites, após descansar um pouco, precise estudar sobre o que aprende e realizar os deveres estipulados pelos professores a serem feitos em casa.

Ana (36) é esteticista de um salão de beleza no bairro Butantã. Lá, além dos procedimentos de massagens e limpeza de pele, ela faz serviço de manicure, pedicure e depilação. Ela fala e exibe com orgulho os certificados dos cursos técnicos realizados para se aperfeiçoar na profissão. Ela trabalha de terça a sábado no local e, na segunda, que é seu dia de folga, atende clientes em casa, quando preciso. Além do que, como já mencionado, à noite também faz atendimentos esporádicos. A informante afirma que, em seu trabalho, a sincronia e o cumprimento de horário são essenciais para garantir todos os atendimentos do dia sem nenhum problema de atrasos entre uma cliente e outra. E ressalta que o diálogo e o respeito entre as colegas de trabalho fazem do ambiente um lugar agradável de trabalhar. Quanto às inúmeras e variadas clientes que atende diariamente, relata:

Já me acostumei que tem umas cliente mais chata, que às vezes tão de mau humor, mas que a gente já se acostumou umas com as outras. E também como eu já conheço cada uma...eu sei que a pessoa já tá daquele jeito por alguma razão que não o meu serviço. Sei também qual cliente eu posso trocar o horário se precisar, qual eu não posso porque fica braba... mas tudo se entende com conversa lá! (Ana, 36).

Apesar de terem uma jornada de trabalho longa e exaustiva, Pâmela (39) e Ana (36) exaltam, com frequência, o fato de serem "trabalhadoras" e "batalharem" para ter o que têm: "A gente corre atrás. No sentido de ser batalhadora mesmo, de acordar cedo e ir trabalhar, não ter preguiça de trabalho, de buscar as coisas” (Ana, 36). 
O trabalho configura o dia a dia das informantes e, em conformidade com que afirma Bourdieu (2007), os agentes da classe popular se comportam como trabalhador até mesmo no uso do tempo livre, afinal, dedica-o a atividades que podem complementar a renda, além de trabalharem também nas tarefas domésticas. O trabalho é essencial para a determinação do capital econômico da família, bem como tem valor simbólico e moral, sendo que "o valor moral atribuído ao trabalho compensa as desigualdades socialmente dadas, na medida em que é construído dentro de outro referencial simbólico, diferente daquele que o 'desqualifica' socialmente" (SARTI, 1996, p. 67, grifo da autora). Ser uma familia de pessoas trabalhadoras é ainda uma forma de obter "afirmação pessoal e social" (Ibdem, p. 68). Isto porque o trabalhador:

[...] é um ser que se faz no dia-a-dia, no trabalho que realiza, que prova e mostra que ele é capaz de construir. Não no sentido redutor da prática, desconectada e alienante. Mas, no sentido da práxis, ou seja, é a partir de sua atividade concreta diária que a realidade se abre para ele (FIGARO, 2000, p.41).

Mesmo que a identidade do trabalhador seja comumente associada à de pobre (CALDEIRA, 1984, ZALUAR, 2000), a carga negativa dessa associação é relativizada pelos valores morais. Ou seja, é por meio do valor positivo atribuído ao trabalho que se manifestam, por exemplo, na disposição em trabalhar exaustivas horas e na honestidade. Assim:

[...] ao lado da negatividade contida na noção de ser pobre, a noção de ser trabalhador dá ao pobre uma dimensão positiva, inscrita no significado moral atribuído ao trabalho, a partir de uma concepção da ordem do mundo social que requalifica as relações de trabalho sob o capital" (SARTI, 1996, p. 67, grifos da autora).

Ambas as irmãs não terminaram o Ensino Médio, pois a jornada de trabalho das duas fazia com que ficasse difícil estudar e trabalhar ao mesmo tempo, além do que Pâmela engravidou enquanto estava tentando concluir os estudos. Não restou outra opção às irmãs que optar pelos seus empregos. A relação das duas com a escola foi complicada desde criança, já que, nessa época, também precisavam dividir o tempo entre o trabalho na lavoura de algodão e a escola. O pai não deixava elas estudarem, e era a mãe que, quando conseguia, levava as meninas para estudar: 
P: A gente tinha que trabalhar, porque estudar, para ele era coisa de gente fresca.

A: A gente até ia, tinha dia que minha mãe levava a gente escondido.

$P: E$, minha mãe levantava cedo e fazia o serviço, meu, da minha outra irmã e dela para a gente estudar. Tinha uma professora que ficava na casa da minha vó e tinha um galpão. Ela dava para as criança da comunidade lá. Era a professora que dava o caderno, os lápis e borracha tudo apara gente. Às vezes para gente poder ir para escola a gente ia depois de trabalhar. Daí as outras crianças tudo corriam da gente porque elas iam arrumadinha e tudo e a gente ia direto, descalço.

Hugo (19) estuda à noite em uma escola pública próxima à residência da familia, ele está cursando o último ano do Ensino Médio. Durante o dia, o jovem trabalha como estoquista em um supermercado, tendo apenas um dia de folga na semana. Ele já reprovou de ano duas vezes e, segundo a mãe, não gosta de estudar. Porém, ela entende que isso possa acontecer porque ele está sempre cansado devido à sua jornada de trabalho. A situação em que se encontra o jovem é típica em diversas familias de classe popular:

os filhos das classes populares são obrigados desde a adolescência a estudar e trabalhar para ajudar em casa - obviamente, na imensa maioria do caos, acabam não fazendo bem nem uma coisa nem outra (SOUZA, 2018, p. 142).

Vinícius (12) também estuda em uma escola pública localizada perto da casa em que moram. E, apesar de nunca ter reprovado, Ana (36) diz que recebe reclamações da escola a respeito do filho: "Ele dá trabalho direto... conversa muito na sala de aula, não presta atenção, faz bagunça, tudo ele acha que é graça, a professora fala e ele começa a rir". O garoto fala que quer ser jogador de futebol e, por isso, treina duas vezes por semana num time do bairro e participa de inúmeros torneios. Ele assiste à maioria dos jogos de futebol que passam na televisão e diz: "Fico assistindo e me imaginando lá no estádio jogando futebol num time grande desse!” (Vinícius, 12). O sonho do jovem é compartilhado e até vivenciado por outros jovens de classe popular no Brasil, pois o futebol, "além de ser considerado a paixão nacional é visto como uma oportunidade de ascensão social e profissional para jovens oriundos de familias de baixa renda" (MARQUES e SAMULSKI, 2009, p. 103). 
As duas mães, mesmo tendo baixa instrução escolar, aconselham os dois jovens a estudarem para que possam ter "melhores oportunidades na vida", e diferentemente delas, ter um trabalho que seja bem remunerado e não os “canse muito". Porém o fato dos meninos não verem ou aproveitarem o estudo como uma oportunidade para alcançarem uma vida melhor se deve, justamente, ao exemplo dos pais, pois, se o jovem percebe que a escola não proporcionou nenhuma mudança no comportamento e na vida dos pais, é difícil que vislumbrem um futuro melhor associado à ida à escola (SOUZA, 2011). Além do que essa necessidade que os jovens das classes populares têm de trabalhar devido ao baixo capital econômico da família faz com que a escola esteja sempre como segunda opção em detrimento da complementação da renda familiar. Afinal, dependendo do lugar que os agentes ocupam no espaço social, “[...] podem mobilizar de forma diferente os recursos materiais e simbólicos que as instituições oferecem" (SOUZA, 2011, p. 294).

Apesar de incentivarem os filhos de que devem ler livros, Pâmela (39) e Ana (36) não têm o hábito de leitura. Os poucos livros lidos por Ana (36) são de literatura espírita e de autoajuda. Sifuentes (2014) e Oliveira- Cruz (2016) também observaram o gosto por esse tipo de literatura nas suas pesquisas com outras mulheres de classes populares.

Desta forma, a Família 1 tem baixo capital cultural advindo da escola, e, por conseguinte, é a mídia, especialmente a televisão (a telenovela e o telejornal) e a internet (com as redes sociais), a principal fonte de formação desse capital.

É importante ressaltar alguns aspectos sobre a história de vida dos membros da familia, principalmente aqueles relacionados às duas mães chefe da casa. As duas são naturais de uma área rural da cidade de Guanambi, na Bahia, e têm mais seis irmãos. Ambas saíram da Bahia muito jovens e vieram para São Paulo à procura de uma condição de vida melhor. A primeira a chegar foi Pâmela (39), acompanhada de uma tia, e elas foram morar no bairro do Ipiranga, na zona Sudeste da cidade:

Eu saí da minha casa com 13 anos de idade, não tinha ninguém por mim e eu sustentei filho sozinha, eu batalhei sozinha... eu graças a Deus não roubei, não me prostituí, não precisei de nada disso. Eu sempre trabalhei, eu nunca escolhi trabalho na minha vida. Era trabalho honesto eu tava ali, eu não tinha vergonha. Por isso, eu não entendo essas meninas que se prostituem, umas menina nova, ao invés de estudarem e trabalharem ficam se vendendo (Pâmela, 39). 
Ana (36) veio dois anos depois que a irmã, com 12 anos, e foi morar no mesmo lugar em que as outras integrantes da familia moravam. Durante muitos anos, ela trabalhou como dançarina de forró, axé, lambada, fazendo apresentações, mas parou de trabalhar com a dança quando engravidou de Vinícius, aos 25 anos. Hoje em dia, os outros irmãos e a mãe também moram em São Paulo.

Elas relatam que a infância no Nordeste foi "super difícil", o pai era alcoólatra e agredia elas e os irmãos e também a mãe: "Mas ele não sabia bater, ele vinha com pedaço de pau para dar na gente. Minha mãe ia defender e daí pegava nela...ela ficava toda marcada. E ele foi assim a vida inteira, até ele morrer ele foi assim” (Pâmela, 39). Além do mais, o pai era muito "rígido" e exigia que elas, com 6 e 9 anos, e os irmãos maiores também trabalhassem na lavoura de algodão, plantando, colhendo e "deixando tudo pronto para ele ir vender" (Pâmela, 39). Ana (36) acrescenta que o pai estipulava uma meta diária em quilogramas que eles deveriam cumprir e que retirar o algodão da flor era uma tarefa difícil de ser executada pelo fato da planta ser dura:

Várias vezes a gente machucava e furava os dedo. Machucava bastante. Nem unha a gente tinha, porque machucava mesmo. E era descalço, no sol quente, podia tá frio ou chovendo, não tinha nada para se proteger. Não tinha desculpa, tinha que ir! Quantas vezes a gente doente tinha que ir (Ana, 36).

Para Pâmela (39), os piores momentos do trabalho eram quando apareciam cobras, pois ela tinha muito medo de ser mordida pelo animal, o que nunca aconteceu: "Eu tinha muito medo, eu passava muito apuro. Eu chorava e dizia: Ah eu não vejo a hora de sair dessa vida porque era difícil".

Além dos afazeres na lavoura, as irmãs falam que precisavam ajudar a mãe a executar as tarefas domésticas. E garantem que não tinham alternativa naquele momento e nem muito tempo de sentir tanta tristeza, pois era "trabalhar ou apanhar".

Mas, apesar de tanto trabalho, a familia tinha sérias dificuldades financeiras. A casa não tinha eletricidade e as refeições, muitas vezes, eram escassas:

Não tinha horário certo para comer e nem refeição certa também. Tinha dia que a gente comia bem, tinha dia que a gente não comia bem... tinha dia que a gente comia 3 vezes ao dia, de manhã, de tarde e de noite. E tinha dias que a gente só tinha o almoço ou então a janta (Pâmela, 39). 
Ana (36) acrescenta que na realidade delas, "não tinha férias, não tinha feriado, não tinha Natal, não tinha aniversário...não tinha nada" e que a família, por não ter eletricidade, não tinha nem geladeira e nem televisão. A família só teve acesso a esses bens alguns anos depois, quando se mudaram para a cidade e as condições, mesmo que ainda precárias, melhoraram um pouco. Pâmela relata que esta infância cheia de dificuldades financeiras fez com que ela desenvolvesse um trauma relacionado ao consumo:

O meu sonho de criança era ter um sapato bonito, uma roupa bonita, às vezes hoje só para me satisfazer, porque a gente tinha tanta vontade de comprar e não podia, hoje eu compro. Eu não preciso, mas se eu posso comprar, eu compro. Mas eu tenho que parar com esse trauma de criança! É sapato e perfume, minhas fraqueza (Pâmela, 39).

Em uma espécie de terapia em conjunto, Ana (36) pergunta se o hábito de comprar sapatos e perfume sem nem precisar era realmente um trauma causado pela infância pobre que tiveram e Pâmela (39) responde, reforçando a afirmação: "Claro, porque eu nunca tive! A gente nunca teve. Eu tinha um chinelo havaiana que eu usava para poder ir para as festa, cê tem noção? Cê ir de chinelo havaiana para uma festa? Em contrapartida, Ana (36) diz que, talvez por autodefesa, muitas das más lembranças relacionadas aos tempos dificeis na Bahia foram "apagadas" de sua memória.

Apesar de tudo, elas afirmam que não têm razões para reclamar e valorizam a experiência vivida na infância: "Se a gente tivesse tido uma vida mais fácil, a gente não seria o que a gente é hoje...do bem, trabalhadora" (Ana, 36). Acrescentam que as dificuldades, não só na Bahia, mas também em São Paulo, as tornaram muito unidas, e até hoje, por mais que discutam por pensarem e agirem, em algumas situações, de maneiras diferentes, tudo acaba se resolvendo com diálogo, "aqui em casa existe muito respeito" (Ana, 36).

Mesmo com as memórias da infância de condições precárias no Nordeste, Ana (36) e Pâmela (39) asseguram que os pais também ensinaram a elas e aos irmãos valores importantes:

A: Eles sempre falavam para a gente não fazer coisas más, não se prostituir, andar sempre certo né...pra não mexer nas coisa dos outro. Minha mãe sempre falava que a mulher para ter a primeira relação tinha que casar...eles sempre davam conselhos bons, a única de mal é que não deixavam a gente estudar. 
P: Meu pai era muito inginorante, mas sempre deu conselhos bom que a gente carrega até hoje né. Nunca pegar nada de ninguém, nunca responder os mais velhos sem ter respeito, desde pequenas...coisa que a gente carrega até hoje assim.

As boas memórias estão relacionadas ao rio perto da casa em que, além de irem buscar água para usar na casa, nadavam e brincavam, nas bonequinhas feitas da espiga de milho em que "o cabelo da boneca era o cabelo natural da espiga, ruivinho" e nas músicas das duplas caipira Gino e Geno, Tonico e Tinoco escutadas nos LPs depois da mudança para a cidade e nas músicas tocadas pelo pai em sua sanfona.

Vinícius (12), conforme a mãe, é um menino "ligeiro", "danado" e independente, assim como ela e o pai dele. Ana (36) relaciona a falta de obediência do filho ao comportamento que ela também costumava ter com seu pais quando criança e jovem: "Ele faz o que ele quer...é só eu dizer para ele não ir em um lugar, que se ele tiver vontade, ele vai!’. Vinícius (12), inúmeras vezes, testa os limites da mãe, como uma forma de chamar atenção dela. Como já afirmado, segundo as informantes, na casa da Familia 1, tudo acontece na base da conversa e do respeito, mas quando alguma situação com Vinícius (12) foge do controle de Ana (36), mesmo sem a aprovação da irmã, ela briga e até "bate" nele. Depois que isso acontece, o menino conta que obedece à mãe e fica "quietinho em casa" por um tempo. Mas diz que não ver problema em sair com os amigos, principalmente para jogar bola, ou ir na casa do pai quando tem vontade, desde que não esteja fazendo "nada de errado, se envolvendo com gente que usa droga e tal" (Vinícius, 12). Até porque afirma que a mãe, a tia, o pai e o ex-marido da mãe sempre o aconselham a ir "pelo caminho certo".

O jovem não tem nenhuma má recordação da sua mãe e seu pai juntos porque eles nunca foram namorados ou casados. E, segundo Vinícius (12), os pais têm uma relação boa, "normal". Ele salienta duas boas lembranças em sua vida: a primeira foi quando beijou uma menina pela primeira vez, no ano retrasado. E, apesar de todos os assuntos relacionados a relacionamento amoroso e sexo serem conversados na casa com Vinícius (12) e seu primo Hugo (19), ele se sentiu constrangido de contar para a mãe, principalmente porque ela ia "sair contando para os outros" (Vinícius, 12). A outra memória diz respeito a uma viagem ao parque temático Beto Carrero World, localizado no litoral de Santa Catarina. A justificativa é que foi a única viagem que fez até hoje, mas também porque foi “muito legal, da hora!” (Vinícius, 12). 


\section{2) Família 2}

Quadro 3: Perfil dos integrantes da Família 2

\begin{tabular}{|l|l|l|l|l|l|l|}
\hline Nome & Idade & $\begin{array}{l}\text { Local de } \\
\text { Nascimento }\end{array}$ & Escolaridade & Etnia & Religião & Ocupação \\
\hline $\begin{array}{l}\text { Edna } \\
\text { (mãe) }\end{array}$ & 52 & $\begin{array}{l}\text { Porto } \\
\text { Alegre/RS }\end{array}$ & $\begin{array}{l}\text { Pós- } \\
\text { Graduação } \\
\text { (Mestrado) }\end{array}$ & Branca & Não tem & $\begin{array}{l}\text { Advogada e } \\
\text { Professora } \\
\text { Universitária }\end{array}$ \\
\hline $\begin{array}{l}\text { Marina } \\
\text { (filha) }\end{array}$ & 16 & $\begin{array}{l}\text { São } \\
\text { Paulo/SP }\end{array}$ & $\begin{array}{l}\text { Ensino Médio } \\
\text { em andamento }\end{array}$ & Branca & Não tem & Estudante \\
\hline
\end{tabular}

Fonte: Elaborado pela autora

Figura 21: Diagrama da Família 2

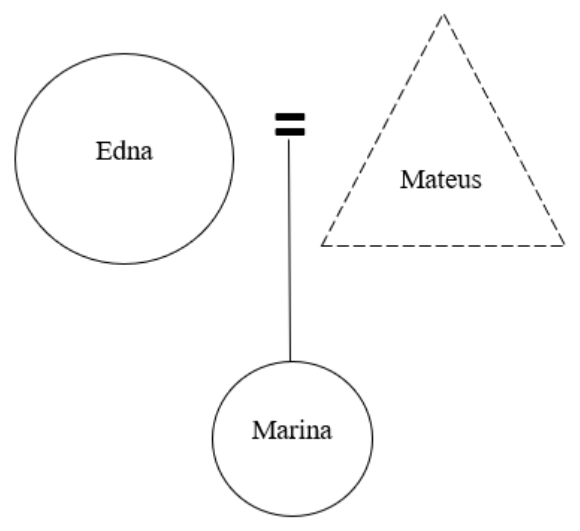

Fonte: Elaborado pela autora

\section{Legenda:}

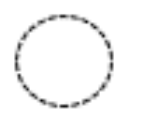

ausentes
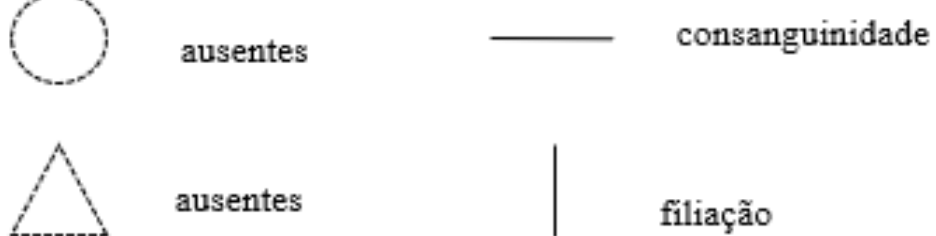

ausentes

filiação

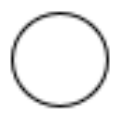

mulheres

$=$ aliança

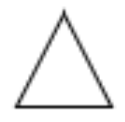

homens

A Familia 2 é composta pela mãe Edna (52 anos) e sua filha Marina (16 anos). 
Edna ficou casada com o pai de Marina por 23 anos e se separou há cinco. Mãe e filha se autodeclaram brancas.

Mesmo com a família de origem católica praticante, Edna (52) afirma não possuir religião. Os avós paternos de Marina (16) são protestantes, mas a jovem também declara não ter religião.

A família mora no bairro Sumaré, no distrito de Perdizes, na zona Oeste de São Paulo. O apartamento, próprio, de cerca de $100 \mathrm{~m}^{2}$, está localizado em um prédio com serviço de portaria 24 horas. Para entrar no local e ter acesso a qualquer apartamento, é preciso se identificar ao funcionário e solicitar autorização do morador. A familia mora no oitavo andar. Logo na entrada, à esquerda estão a cozinha, e em seguida, a área de serviço, divididas por uma porta transparente. A cozinha é conjugada com a ampla sala do apartamento, mas os cômodos são divididos por uma parede que não é inteira, que, ao mesmo tempo que esconde parte da cozinha, a deixa aparente. O cômodo também é dividido por um balcão de vidro marrom e duas banquetas altas que misturam os materiais ferro e madeira. Os eletrodomésticos da cozinha são em inox, tais como a geladeira, a máquina de lavar louça, o forno de micro-ondas e o forno elétrico. O fogão é um cooktop de cinco bocas. Ao sair da área da cozinha, à frente, posicionada próxima ao canto direito da sala, está a mesa de jantar de seis lugares, que é toda de vidro com um pé estilizado em madeira. No centro dela tem uma bandeja de linhas retas e em metal. A maior parede próxima a esta mesa é inteiramente coberta por espelho. O sofá grande, ampliável e vermelho tem um chale colocado em apenas uma parte e está disposto em outra parede. Do lado direito deste, há um cesto com revistas e variadas mantas, caso as moradoras ou visitas queriam se cobrir, e do esquerdo, há uma mesa redonda de madeira com um abajur na cor azul turquesa. Em frente ao sofá, está um móvel de madeira com a smart TV de tela LCD, de 50 polegadas. Atrás desse móvel, há um papel de parede bege com leves texturas. No móvel estão apenas os aparelhos de TV a cabo (a família assina o pacote completo), um relógio, um objeto decorativo e algumas plantas. Algumas vezes Marina (16) ou mãe deixam alguns livros em cima desse móvel. Nesse cômodo, há uma sacada com churrasqueira e uma mesa alta de vidro com três cadeiras. É nessa sacada que ficam a maior parte dos utensílios das duas cachorras da familia, uma Lulu da Pomerânia e uma West Highland White Terrier, mas ambas têm circulação livre na casa. A porta que dá para esta sacada é revestida por uma cortina branca, de tecido leve. A pintura de todo o apartamento é na cor branca, o chão é revestido de porcelanato branco e o teto de gesso, 
com algumas nuances rebaixadas. Todos os móveis do apartamento, sem exceção, foram feitos sob medida, assim "todos os espaços foram bem aproveitados". O corredor que dá para os três quartos do apartamento é separado da sala e cozinha por uma porta de correr, também branca, isolando a parte privada quando necessário. Nesse corredor, à direita, há um banheiro que é utilizado por Marina (16) e pelas visitas. À esquerda, há o quarto de hóspedes e escritório, em seguida, o quarto de Marina (16). O último quarto da casa, à esquerda, é o de Edna (52) e possui suíte e outra sacada. Os quartos de Marina (16) e Edna (52) possuem televisão, mas o aparelho maior e assistido com mais frequência pelas duas, está na sala.

O espaço de sociabilidade da família é esse cômodo principal composto pela sala e cozinha. E diversas vezes, quando Marina (16) recebe as colegas para realizar os trabalhos escolares, esse espaço é ampliado às áreas comuns do prédio. Os quartos são os espaços privados, delimitados pela porta do corredor. 


\section{Figura 22: Sala com a principal televisão da casa da Família 2}

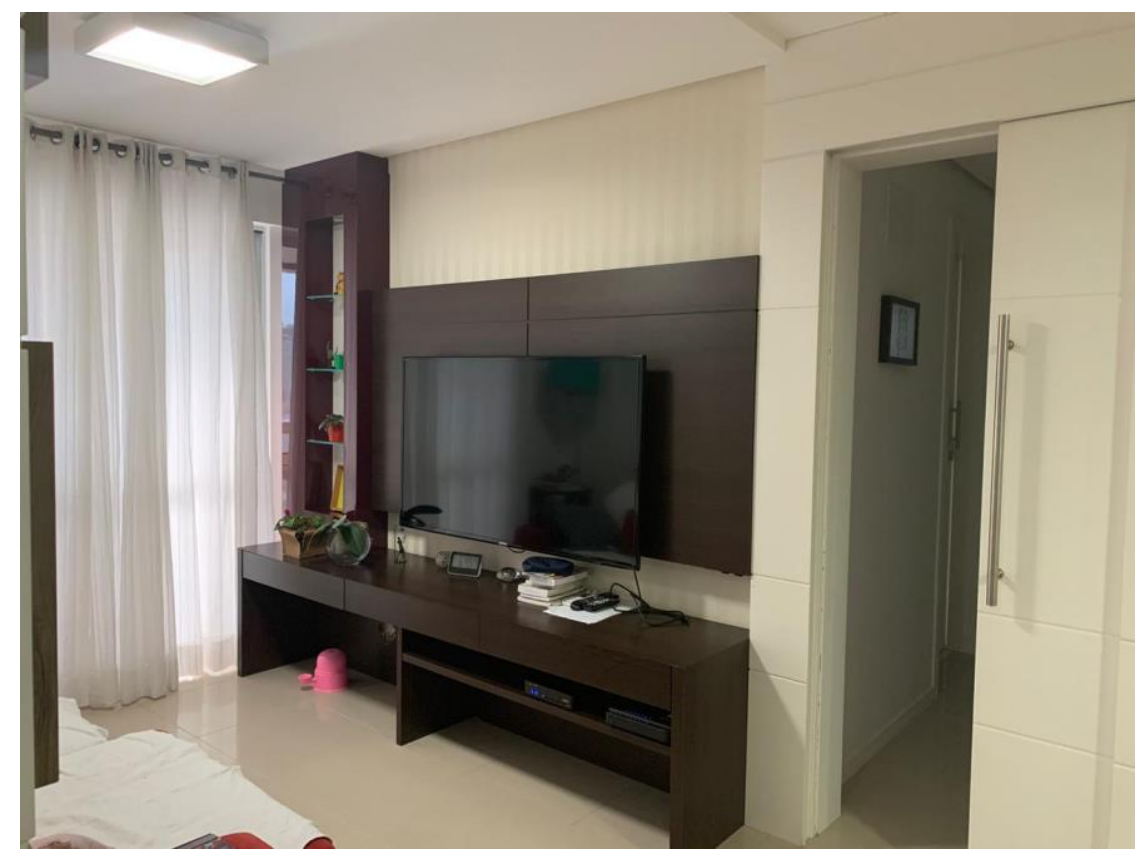

Fonte: Arquivo pessoal da pesquisadora

A organização e a limpeza da casa é realizada por uma funcionária que vai ao local duas vezes na semana. Porém é Marina (16) quem toma conta da limpeza e alimentação das duas cachorrinhas, pois essa foi a condição imposta pela mãe na hora de aceitar os animais. Uma delas foi presente do pai e a outra, anos depois, foi comprada por Edna (52) a pedido da filha. As refeições, em alguns dias, são feitas por Edna (52) e, em outros, mãe e filha almoçam fora.

Edna (52) estudou Direito na Universidade Federal do Rio Grande do Sul e fez Mestrado na área de Direito de Familia. Ela é professora de uma universidade privada e também atende em seu escritório de advocacia, pegando casos, principalmente, em sua especialidade. O grande volume de trabalho por conta dos processos e da carga horária em sala de aula e no escritório-modelo da universidade, faz com que Edna (52) tenha que organizar os seus horários de maneira a não perder os prazos processuais e o horário de funcionamento dos fóruns. Ela conta: "Sou metódica com horários e compromissos, odeio me atrasar, tanto é que acordo bem mais cedo para evitar qualquer problema". Aponta que uma das dificuldades encontradas em seu trabalho é a burocracia dos fóruns e a morosidade da justiça no país: 
poucos funcionários efetivos e muitos estagiários, o que prolonga mais ainda o tempo de espera de andamento dos processos. Por isso que, cada vez mais é preciso que se coloque em prática as conciliações por mediação, para desafogar o sistema e dinamizar os processos" (Edna, 52).

Edna (52) fez ballet clássico desde criança e, até hoje, é apaixonada pela dança e estudou francês durante muitos anos. Atualmente, estuda inglês devido às viagens internacionais que faz, pois sente falta de falar e entender, "pelo menos o mínimo" para se comunicar. Ela tem o hábito de leitura desde criança, pois, como demorava para dormir, sua mãe permitia que ficasse na cama, lendo um livro até pegar no sono. Hoje em dia lê cerca de um livro por mês, e sua literatura preferida é a policial, de suspense e também alguns romances.

A filha Marina (16) está no segundo ano do Ensino Médio de uma escola privada próxima à residência da família. Ela foi alfabetizada em uma escola bilíngue, então desde pequena fala inglês com fluência. Apesar de não gostar de algumas disciplinas, a menina é estudiosa e nunca reprovou de ano ou ficou em exame e sempre passa de ano antes mesmo do ano letivo terminar devido às boas notas. Tanto Edna (52) quanto Marina (16) relatam que a mãe nunca teve que cobrar que a jovem estudasse: "Tenho as minhas responsabilidades, a mãe nunca precisou checar se estou estudando ou não. Mas ela e o pai me ajudam com alguma matéria sempre que eu preciso" (Marina, 16). A garota lê diariamente, e, durante o dia, dá preferência aos livros obrigatórios para a escola, e à noite escolhe os extra escolares. Ela gosta de livros de romance, de suspense, policial e diz ter o hábito da leitura desde pequena: “Adorava quando a minha avó vinha nos visitar e íamos para alguma livraria, como a Cultura, por exemplo. Ficávamos horas sentadas lá dentro lendo e depois ela sempre me dava de presente o livro que eu escolhesse" (Marina, 16). A jovem conta com empolgação que está se preparando para fazer um intercâmbio na Inglaterra, durante os três meses de férias escolares. Ela irá para Londres com o objetivo de aperfeiçoar o inglês.

Quanto à carreira a ser seguida, apesar de ter ainda mais esse ano e o próximo na escola, a jovem já decidiu que irá fazer faculdade de Psicologia. Souza (2018) afirma que esse investimento pesado na educação dos filhos é característica de famílias de classes altas, pois, para ele, a classe média compra o tempo livre dos filhos para se dedicarem apenas ao estudo.

Assim, a Familia 2 tem um alto capital cultural acumulado oriundo tanto das 
instituições quanto da familia. Para eles, a manutenção desse capital já é algo incorporado e é ele que, aliado aos capitais econômico e social, mantém a posição privilegiada de classe que ocupam.

Quanto às questões relacionadas à história das informantes, é pertinente ressaltar que Edna (52) narra que teve uma infância tranquila e confortável junto aos pais e os outros dois irmãos, em Porto Alegre, no Rio Grande do Sul. Os pais são professores universitários pós-graduados na área de Administração e, segundo ela, "sempre foram um casal certinho, amoroso e unido e sempre nos deram exemplo de conduta impecável, tanto como casal, quanto profissionais” (Edna, 52). Acrescenta que os pais não eram muito exigentes com nenhum dos filhos porque "nós não dávamos motivo, cumpríamos com as nossas obrigações".

Além dos bons exemplos, os pais davam conselhos quanto à necessidade de estudar para terem um bom trabalho e se tornarem independentes, "minha mãe sempre dizia para mim e minha irmã: primeiro vocês estudem para ter uma profissão e serem independentes, se casarem ótimo, se não sem problemas, o importante é não depender de ninguém" (Edna, 52).

As refeições da familia eram realizadas sempre nos mesmos horários e na mesma hora, "todo mundo jantava e almoçava junto, com raras exceções por causa de aula ou trabalho" (Edna, 52). Ela diz que a familia sempre teve, pelo menos, uma empregada doméstica, em alguns momentos eram duas. Mas, quando elas estavam em férias, ela e os irmãos ajudavam a manter a casa organizada, "era nossa obrigação arrumar os nossos quartos e o pai que fiscalizava". Conta, rindo, que o irmão, que é mais velho, não gostava muito desta tarefa, mas que então a irmã do meio, que sempre gostou de organizar tudo, ajudava ou até mesmo arrumava todo o quarto do irmão antes do pai chegar para conferir.

Edna (52) saiu do Rio Grande do Sul para acompanhar o marido, que na época era namorado, ele é farmacêutico e foi para São Paulo trabalhar no setor de epidemiologia do governo do Estado. Ela acabou se colocando na cidade e, hoje, construiu a vida na capital paulistana.

Com a filha, Edna (52) aplica tudo o que aprendeu em casa com os pais e irmãos. Elas têm uma boa relação baseada na conversa e na confiança: "Marina tem liberdade, mas sabe também dos seus limites. Imponho de uma forma tranquila, mas ela precisa saber que tem limites, principalmente nessa idade” (Edna, 52). Ela diz que a 
filha conta todas as experiências que vive e que, inclusive, por meio das histórias da adolescente, entendeu que, quantos às relações interpessoais, hoje em dia "eles querem experimentar coisas de uma maneira livre" (Edna, 52). Fala rindo que "se presta" para ouvir as histórias dos "ficantes" da filha e que a jovem "a faz" ficar horas olhando o Instagram dos meninos com quem se envolve.

Marina (16) sente orgulho da relação de confiança estabelecida entre ela e a mãe e diz que os limites impostos são compreensíveis e que sempre procura avisar aos pais onde está, "por uma questão de segurança mesmo, não porque acho eles chatos de me cobrarem isso" (Marina, 16). A menina diz que a mãe sempre aconselhou que ela escolhesse uma profissão que desse estabilidade financeira, mas que também fosse satisfazê-la. Muito rapidamente, ela diz que, mesmo quando a mãe esteve doente de depressão e crise de ansiedade devido à complicada separação com o pai, não se sente traumatizada: "Nunca tive mágoa nem da depressão da minha mãe e nem da separação deles, foi uma época e não mudou a nossa relação, apesar de terem sido momentos difíceis, os nossos momentos bons superam as dificuldades" (Marina, 16).

As duas falam com alegria dos momentos que desfrutam juntas, seja em casa, em restaurantes, no cinema ou nas viagens que fazem. No ano passado, foram para Disney e, no final do ano, quando Marina (16) estiver na Inglaterra para o intercâmbio, a mãe irá encontrá-la para passarem as festas de fim de ano juntas.

\subsection{A telenovela $O$ Sétimo Guardião}

O que farei a seguir é uma síntese sobre a trama e alguns dos principais elementos que definiam os argumentos e desenrolar desta narrativa de Aguinaldo Silva. Isto porque seria uma tarefa impossível transpor aqui todo o seu desenvolvimento, visto que uma telenovela é uma obra extensa:

Se é certo que uma telenovela brasileira tem por volta de 160 capítulos, e que cada capítulo tem em média 45 minutos de história, tem-se que a imagem gravada da novela padrão possui hoje, em média 120 horas de duração. Se pensarmos em termos de papel escrito, podemos dizer que um capítulo é escrito em aproximadamente 30 páginas, portanto a telenovela consome 4.800 páginas de texto, uma pilha de papel de um metro e meio de altura (PALLOTTINI, 1998, p. 62).

A telenovela $O$ Sétimo Guardião foi ao ar pela Globo de 12 de novembro de 
2018 a 18 de maio de 2019, no horário das 21 horas. A trama de 161 capítulos foi escrita por Aguinaldo Silva e Joana Jorge, com colaboração de Maurício Gyboski, Zé Dassilva e Virgilio Silva. A autoria da telenovela foi alvo de polêmica e processo na justiça, pois um dos alunos da Master Class de roteiro ministrada pelo autor, em 2015, reivindica a coautoria da trama. Isto porque a sinopse foi desenvolvida durante o curso. Os nomes dos 26 alunos participantes apareceram creditados no encerramento dos capítulos. A direção artística foi de Rogério Gomes, e a direção geral, de Allan Fiterman.

Apesar de ter tido algumas cenas gravadas em São Paulo, a maior parte da trama foi rodada em uma cidade cenográfica. Ela foi utilizada por todo elenco, pois a maioria da trama se passou nesta cidade construída, sendo o local o ponto central da história. Desta maneira, a cidade cenográfica de Serro Azul foi construída dentro dos Estúdios Globo com requintes de realismo e perfeição para reproduzir uma verdadeira cidade do interior com igreja, prefeitura e uma praça onde muitas ações da trama aconteciam. A cidade tinha o tamanho de 18 mil metros quadrados onde foram construídas 38 edificações e 27 delas com interior, ou seja, as casas de vários personagens foram construídas dentro da própria cidade cenográfica.

A fonte com poderes rejuvenescedores e curativos, central na história, também não era real, ela foi fabricada num galpão com 1.800 metros quadrados e, ao contrário do que parecia, não era feita de pedra e sim de ferro revestido de tecido com textura, dando sensação visual de rocha. Para a queda de água de seis metros, foram utilizados 65 mil litros de água, reaproveitada em um sistema de filtragem similar aos de piscinas. A água límpida e azul é resultado de uma pintura azul em dégradé que era iluminada por um refletor. Além do mais, para dar mais realismo ao local, o ambiente foi climatizado para chegar, o mais próximo possível, à temperatura real de uma gruta ${ }^{64}$. Os valores gastos com todas estas estruturas para a gravação da telenovela não foram divulgados pela Globo.

\footnotetext{
64 Todas estas informações técnicas foram retiradas de reportagens de divulgação da telenovela no Gshow, no site www.globo.com. A exemplo: https://gshow.globo.com/novelas/o-setimoguardiao/noticia/fonte-de-s erro-azul-fica-dentro-de-gruta-cenografica-climatizada-confira-detalhes.ghtml Acesso em dezembro de 2018.
} 
Figura 23: Cidade cenográfica de Sermo Aaul- O Sétimo Guardião

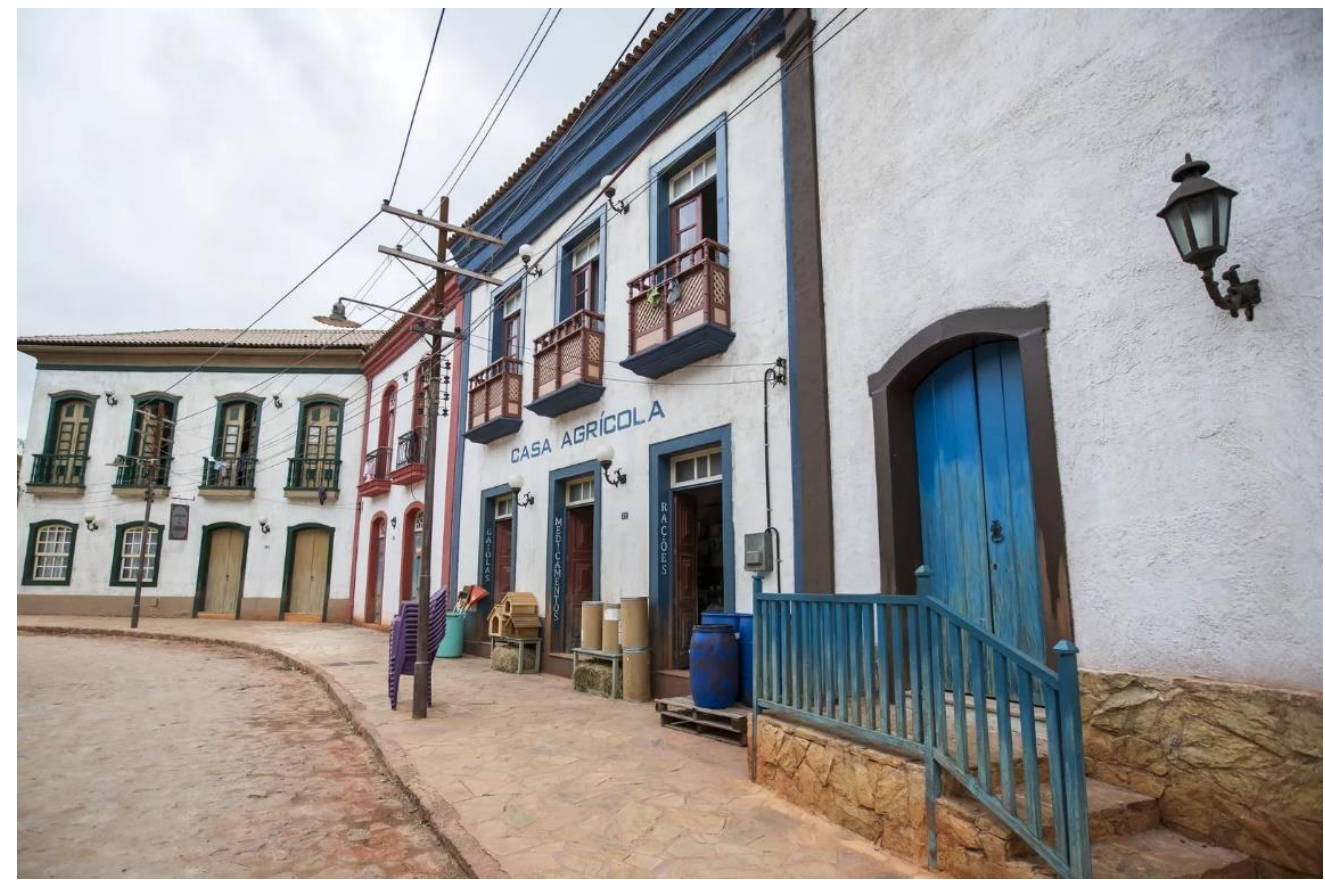

Fonte: Gshow

Figura 24: Fonte cenográfica - $O$ Sétimo Guardião

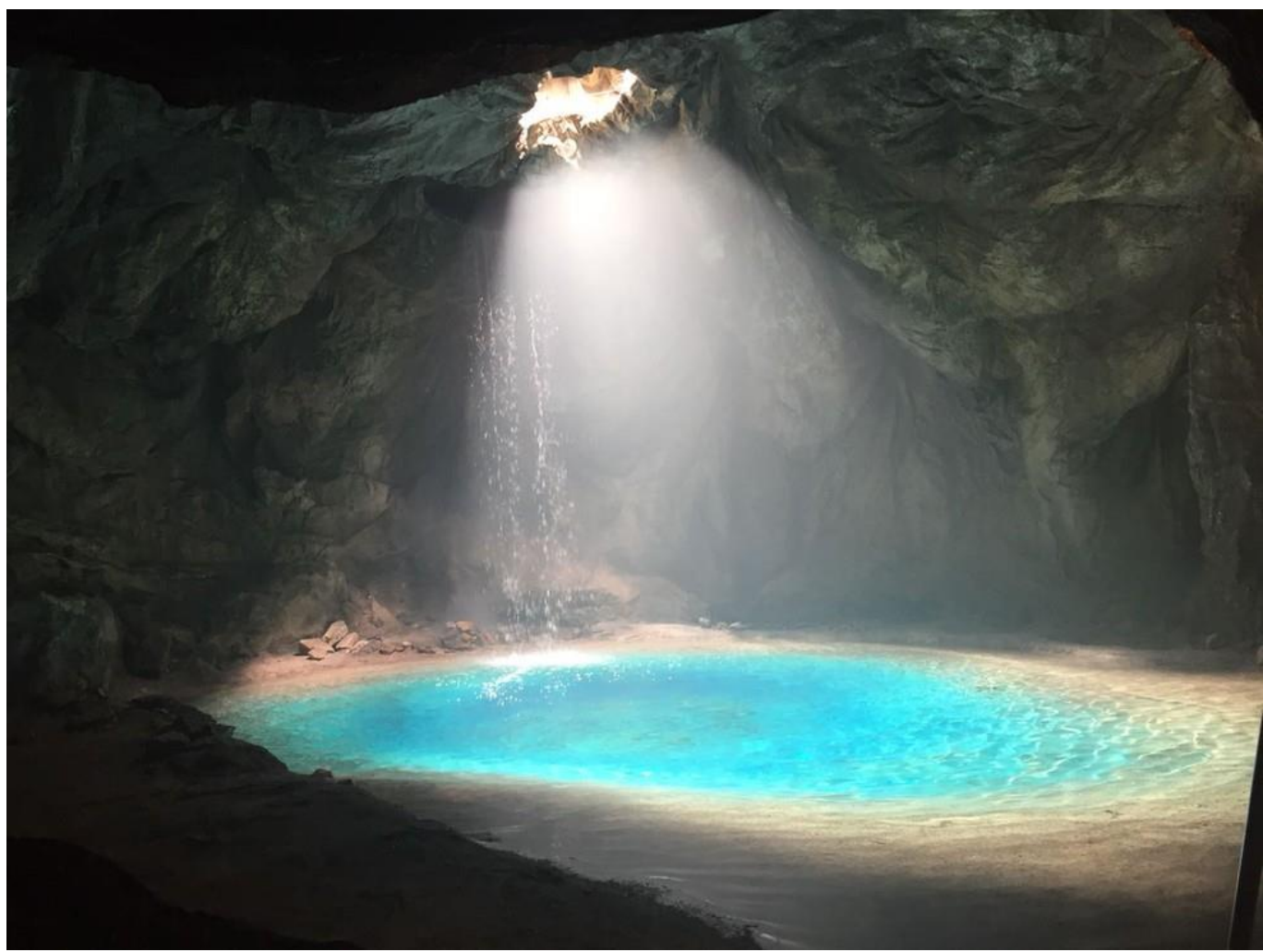

Fonte: Gshow 
O elenco principal da telenovela era composto por uma mistura de atores e atrizes renomados da teledramaturgia do país com jovens talentos, como Lilia Cabral, Tony Ramos, Marina Ruy Barbosa, Bruno Gagliasso, Dan Stulbach, Milhem Cortaz, Antônio Calloni, Paulo Rocha, Ana Beatriz Nogueira, Leopoldo Pacheco, Zezé Polessa, Marcos Caruso, Elrabeth Savalla, Vanessa Giácomo, Letícia Spiller, Flávia Alessandra, Marcelo Serrado, Carolina Dieckmann, José Loreto, Caio Blat, Yanna Lavigne, Marcello Novaes, Femanda de Freitas, Isabela Garcia, Ailton Graça, Bruna Linzmeyer, Giullia Buscacio, Carol Duarte, Paulo Vilhena, Viviane Araújo, Júlia Konrad, entre outros.

A trama marcou a volta de Aguinaldo Sìva ao realismo mágico, já que o gênero não era apresentado pelo autor desde a telenovela Porto dos Milagres (Globo, 2001). O realismo mágico apresentado na ficção brasileira tem relação com o realismo grotesco (BAKHTIN, 2008) e com a narrativa fantástica (TODOROV, 1975), pois remetem a um sistema estético da cultura cômico-popular que tem como central uma lógica contrária à da experiência acumulada no cotidiano. Ou seja, utiliza os princípios de rebaixamento e inversão, já que não é desenvolvido sob uma forma perfeita, simétrica dentro de uma ordem ou padrão. É caracterizado pelo movimento, pelo inacabado, abstrato. Há, nesse gênero, uma complexidade temática em que as ordens do real e do irreal se afastam (CHIAMPI, 1980), em que "ocorre entre a incerteza e a impossibilidade de haver alguma explicação ao sobrenatural, derrubando as convenções culturais e também diegéticas" (SACRAMENTO, 2014, p. 171). No realismo mágico, as tramas apresentadas podem conter "surpresas nem sempre inteligíveis (LOPES, BORELLI e RESENDE, 2002, p. 295).

Mas, ao contrário das demais telenovelas de Aguinaldo Silva, o realismo mágico de $O$ Sétimo Guardião não foi associado apenas à comédia, mas sim a outros gêneros como suspense e drama. Ainda em oposição às outras telenovelas do autor, que eram de realismo mágico, esta tinha uma atmosfera soturna. Assim, as manifestações deste realismo estiveram presentes na história com o clima de mistério e de sobrenatural, da fonte com propriedades curativas e rejuvenescedoras, com o gato que se transformava em homem e vice-versa, com buraco que se abria no chão, ventos fortes que anunciavam um acontecimento misterioso, uma bola de cristal que, algumas vezes, mostrava o futuro e as visões premonitórias da personagem protagonista. Para dar maior materialidade a esse realismo mágico, a direção utilizou diversas cenas escuras, variados efeitos sonoros, tanto em ações cômicas quanto nas de suspense, trilha sonoras 
e também posicionamentos e marcações de câmera que imprimiam às cenas o mistério pretendido pelo autor.

Apesar do pano de fundo diferenciado por conta do mistério e do suspense que envolvem a fonte, os guardiães e a irmandade, a narrativa de O Sétimo Guardião foi desenvolvida de maneira tradicional, visto que as características do melodrama e o folhetim estavam presentes na obra, com heróis, vilão, mocinha e amores impossíveis. As marcas folhetinescas estão presentes nos textos de Aguinaldo Silva desde que começou a escrever telenovelas na Globo, no início da década de 1980 (ORTIZ, BORELLI e RAMOS, 1989).

Ambientada no sertão de Minas Gerais, Serro Azul é, aparentemente, uma pacata cidade de interior desprovida de recursos tecnológicos como antena de televisão e sinal de TV e internet. A peculiaridade da cidade é que possui uma fonte secreta e milagrosa com poderes de cura e rejuvenescimento, que é a parte mais externa de um gigantesco aquífero. Ela é protegida por sete guardiães com a missão que impedir que a riqueza que é a fonte chegue à mãos de pessoas erradas que queriam tirar proveito dela. Além deles, existe um guardião-mor (Egídio, Antônio Calloni), líder da irmandade de guardiães. Os outros protetores, que, supostamente, levam uma vida normal, são o prefeito da cidade, Eurico (Dan Stulbach), o delegado, Machado (Mihem Cortaz), o médico da cidade, Aranha (Paulo Rocha), um mendigo, Feliciano (Leopoldo Pacheco), a cafetina, Ondina (Ana Beatriz Nogueira) e a esotérica Milu (Zezé Polessa).

Os guardiões são escolhidos através de um ritual secreto realizado na fonte em que usam uma capa preta com capuz e um colar prateado, apenas o guardião-mor veste uma capa branca. Eles são substituídos cada vez que um guardião morre. Perto deles sempre estava presente Léon (na forma humana é Eduardo Moscovis), um gato preto que tinha alguns poderes. Ele foi um guardião-mor, mas, por desobedecer às regras da irmandade e se envolver com uma mulher, pois o guardião-mor não deve ter relacionamento amoroso, foi castigado e transformado em gato. Mas, em algumas situações, Léon se transforma em homem e logo vira gato novamente. Ele não tem o poder de ficar apenas na forma humana, isto acontece ao longo da trama quando a maldição do castigo acaba.

O gato Léon também possui forte ligação com Luz (Marina Ruy Barbosa), uma jovem recém-formada professora que, foi criada pelo avô adotivo Sóstenes (Marcos Canuso). Luz tem sonhos enigmáticos desde pequena e, em alguns desses sonhos, prevê acontecimentos. Além 
do mais, Luz e Léon se entendem através do olhar, e foi o gato que a chamou para resgatar Gabriel (Bruno Gagiliasso) após um acidente sofrido no primeiro capítulo da trama. É Gabriel o próximo guardião-mor.

Ao perceber o desparecimento momentâneo de Léon, Egídio (Antônio Calloni) se dá conta de que o gato foi trazer o próximo guardião-mor, o que significava que sua morte está a caminho, pois um próximo guardião-mor só aparecia quando o atual estava prestes a morrer.

Assim, Léon aparece em frente a Gabriel, em sua casa em São Paulo, minutos antes dele se casar com Laura (Yanna Lavigne). Para sua mãe Valentina Marsalla (Lilia Cabral), uma famosa e rica empresária do ramo de cosméticos, o casamento do filho único era uma maneira de garantir o futuro de seus negócios, já que Gabriel se tornaria genro de um outro poderoso empresário paulista, Olavo de Aragão Duarte (Tony Ramos). Valentina mantém em segredo que, no passado, foi abandonada no altar em Serro Azul por Egídio, pai de Gabriel. Isto aconteceu justamente quando o homem recebeu o chamado para assumir a liderança da irmandade. A história então se repetia, e Gabriel, após receber o chamado através de León, abandona a noiva e segue dirigindo para Serro Azul, sem nunca sequer ter ouvido falar na cidade. Quase na chegada da cidade ele, que nesse momento está sendo seguido pelo capanga da mãe, Sampaio (Marcelo Novaes), sofre um acidente. Sampaio pensa que o jovem está morto, e, por desespero, o enterra vivo. É nesse momento que Luz, acordada do sono por Léon, vai salvá-lo. Começa, então, a história de amor entre os dois. Gabriel é levado por Luz para sua casa em Serro Azul, e a trama da telenovela começa a se desenvolver. Mas o amor dos dois, que cresce a cada dia, é impossível, porque, além da fúria da mãe, da ex-noiva e do ex-sogro, há um obstáculo maior: a fonte e a irmandade. Gabriel, por ter recebido a missão de substituir o guardião-mor, não pode se casar com Luz.

A trama toda se desenrola por conta disso e também pelo fato de que os guardiões devem manter a fonte e seu segredo protegidos. Porém, Valentina e Olavo acabam descobrindo suas propriedades e querem ganhar dinheiro usando a água milagrosa em seus produtos de beleza. Olavo e Valentina se mudam para Serro Azul e moram na mesma mansão, onde passam a telenovela inteira tendo embates. A maioria dos núcleos de ficcionalidade foram elaborados, então, em torno dos guardiões da fonte e seus desdobramentos, como, por exemplo, no casarão onde morava Egídio e agora vive Gabriel e que abriga a fonte misteriosa, o prefeito e suas atividades na prefeitura e 
em casa com sua família (dois filhos, um deles disputa o amor de Luz com Gabriel e a esposa cômica que utiliza a água da fonte às escondidas para se manter jovem), a esotérica e seu trabalho, o mendigo e sua constante tarefa de vigiar tudo o que acontece na cidade de maneira privilegiada, já que mora na porta da igreja, a cafetina e seu trabalho em seu bordel e sua pensão, o delegado desempenhando suas funções e em sua casa com a esposa, o médico no hospital e também em casa. Este último enfrenta grande problema em casa, pois sua esposa Stella (Vanessa Giácomo) tem constantes brigas com a sua mãe, a beata religiosa Mirtes (Elisabeth Savalla). Mirtes também é responsável por outros embates com outras personagens de diferentes núcleos da trama por seu comportamento intempestivo e preconceituoso perante aqueles que, para ela, não seguem a religião como ela segue. Se diz defensora da "moral e dos bons costumes" da cidade. A beata tem um grupo de seguidores fiéis formado por outras duas mulheres e um homem, o Jurandir (Paulo Miklos). Mirtes chegou a criar um site, o "Tarja Preta" para expor os segredos dos "pecadores" da cidade, como por exemplo, a fantasia sexual do delegado Machado em usar calcinhas ao invés de cuecas.

Apesar de a maioria da trama ser em torno do mote da fonte, existem outros núcleos de ficcionalidade em $O$ Sétimo Guardião, como a casa e o trailer de lanche da família de Nicolau (Marcelo Serrado) e Afrodite (Carolina Dieckmann) e seus quatro filhos: Rivalda (Giulia Gayoso), Diana (Laryssa Ayres) Bebeto (Eduardo Speroni) e Cristiana (Vitoria Rangel). O chapeiro é um homem machista que não aceita as escolhas dos filhos, Diana por ser carateca e Bebeto por ser dançarino. Para ele, o esporte da filha é "coisa de sapatão", e a habilidade para dança do filho "não é coisa de macho". Nicolau sonha em ter um quinto filho jogador de futebol, e é justamente a ambição do homem que, ao longo da trama, o faz aceitar as profissões dos filhos interessado no dinheiro que podem trazer à família. Rivalda, a filha mais velha do casal, apoia as atitudes do pai perante o relacionamento abusivo com Afrodite e as atitudes machistas e violentas também com os irmãos. Chega um momento da trama que em Afrodite, cansada do comportamento do marido, pede a separação.

Então, além das ações da trama acontecerem principalmente entre os núcleos de ficcionalidade citados e seus cenários, muito da história acontecia na praça da cidade, os embates, as descobertas e as articulações entre os núcleos. É justamente a praça pública o principal lugar de contato do realismo grotesco, carnavalizado para Bakhtin (2008): 
Nela não só se dão convivências com as diferenças, mas também uma intensa inversão de papéis e hierarquias que configuram a oficialidade do mundo. Na cosmovisão carnavalesca, impera a ambivalência, uma interação entre os opostos básicos na linguagem e na vida - o sério e o cômico, o oficial e o subversivo, o antigo e o novo, o princípio e o fim -, que faz com que os opostos se combinem um ao outro de modo a libertar as palavras do "aperto do sentido, da lógica, da hierarquia verbal" (BAKHTIN, 2008, p.371) (SACRAMENTO, 2014, p. 160, grifo do autor).

O recurso da utilização da praça já é recorrente na teledramaturgia brasileira, especialmente por Aguinaldo Silva:

Diferentemente das convenções do melodrama televisivo tais como descritos na literatura, que favorecem ações em cenários privados ou semiprivados, a praça pública, centro da vida cotidiana em inúmeras cidades do Brasil afora, em frente à igreja matriz, é cenário relevante em Roque Santeiro, como em Irmãos Coragem e Selva de Pedra, O Bem Amado, Gabriela, etc. (HAMBURGUER, 2005, p. 108).

Em O Sétimo Guardião, Aguinaldo Silva fez autorreferência a suas outras obras, uma delas é a telenovela $A$ Indomada, mesma obra estudada no nosso livro inspiração. Greenville, cidade onde se passou A Indomada, era a cidade grande mais próxima de Serro Azul, era citada inúmeras vezes pelos personagens de O Sétimo Guardião, e partes da cidade até apareciam quando algumas personagens precisavam ir a Greenville, para estudar, por exemplo. Personagens da telenovela antiga também entraram na trama de agora, não de uma forma contundente, dando a impressão de que estavam ali apenas para estabelecer a relação com a antiga obra e com a cidade vizinha de Greenville. Estes personagens foram o prefeito, agora cassado, de Greenville, Ypiranga Pitiguari (Paulo Betti) e sua esposa Scarlet Mackenzie (Luíza Tomé) com seus sotaques nordestino com inserções de palavras em inglês. O pai de Scarlet, o político corrupto Pitágoras, também foi referenciado, bem como Altiva Mendonça e Alburquerque, vilã da trama de 1997, que também era citada, e a escola de Greenville tinha o seu nome. Mas as referências do autor às suas outras telenovelas perduraram ao longo de O Sétimo Guardião, nas citações de outros personagens como dona Milu, de Tieta (Globo, 1989-1990) e seu bordão: "Mistério!" e das cidades vizinhas, Resplendor (Pedra sobre Pedra, Globo, 1992) e Tubiacanga (Fera Ferida, Globo, 1993-1994). 
Com base no clipping $^{65}$ realizado e na pesquisa empírica, é importante ressaltar que uma grande expectativa foi gerada em torno da telenovela, por ser escrita por Aguinaldo Silva, que foi responsável por inúmeras tramas de sucesso na Globo, entre elas Roque Santeiro (1985), Vale Tudo (1988), Tieta (1989), Pedra sobre Pedra (1992), Senhora do Destino (2004), Fina Estampa (2011) e Império (2014), esta última vencedora do Emmy Internacional de Melhor Novela de 2014. Mas também, porque a história envolvia mistério e suspense sob a luz do realismo mágico. O material promocional de divulgação da telenovela também proporcionou essa espera. $\mathrm{O}$ autor chegou a afirmar que esta seria a sua melhor telenovela ${ }^{66}$. Porém, a telenovela decepcionou a audiência e a crítica especializada. Ficou entre as cinco telenovelas de piores audiências do horário das 21 horas da história da Globo, já que, segundo a Kantar Ibope registrou uma média de apenas 28,7 pontos. Nem o último capítulo, que normalmente registra bons índices devido à curiosidade dos telespectadores acerca do final das tramas, teve boa audiência, pois O Sétimo Guardião teve o segundo pior último capítulo da história da faixa horária do canal, com 34,2 pontos, perdendo apenas para Babilônia (Globo, 2015), que havia registrado 33,5 pontos.

De acordo com os inúmeros críticos especializados, a telenovela flopou porque, apesar da qualidade de direção, dos atores e do primor técnico, possuía um texto fraco, e os apelos de suspense e realismo mágico foram desaparecendo ao longo da estória. Nem o recurso do serial killer na reta final e a dúvida do "quem matou?" fez a trama decolar. Outra razão levantada pela crítica é que o autor teria se recusado a realizar algumas mudanças necessárias conforme explicitado nos grupos de discussão feitos com telespectadores, prática comum na emissora. Além de tudo, algumas fofocas dos bastidores, como um possível caso extraconjugal entre os atores Marina Ruy Barbosa e José Loreto, culminando em sua separação de outra atriz, Débora Nascimento e escândalos envolvendo uma suposta orgia sexual em camarins, chamou mais a atenção da imprensa e do público do que o próprio enredo da telenovela. O caso de reivindicação judicial de coautoria pelos alunos da Master Class, mesmo antes da estreia, também contribuiu para a esta repercussão da telenovela fora dos limites da estória.

\footnotetext{
${ }^{65}$ Os sites consultados com as notícias sobre a telenovela estão nos anexos da tese.

${ }^{66}$ Disponível em: https://oplanetatv.clickgratis .com.br/noticias/bastidores/aguinaldo-silva-acredita-que-osetimo-guardiao-sera-a-sua-melhor-novela.html Acesso em setembro de 2018.
} 
Com tudo isto, a Globo optou por não vender e nem oferecer $O$ Sétimo Guardião ao mercado internacional, não levando a trama em uma feira realizada em janeiro deste ano em que expôs todas as produções de 2019, a telenovela de Aguinaldo Silva ficou de fora da exposição ${ }^{67}$. Por ironia do destino, anos atrás, no final da década de 1980 , o próprio autor, em entrevista, declarou sobre a relação da audiência com a qualidade de uma trama: "o que uma novela precisa é ser popular. Se é popular é boa. Se a novela tem muita audiência, ela é ótima” (Aguinaldo Silva in: ORTIZ, BORELLI e RAMOS, 1989 p. 159-160).

Em janeiro deste ano, a Globo anunciou que não havia renovado o contrato com Aguinaldo Silva, que, após mais de 40 anos de trabalho, deixou a emissora.

\subsection{A telenovela reeditada (TVN-R)}

Conforme já explicado no capítulo 5, um corpus menor da telenovela foi construído apenas com as cenas escolhidas pelas duas familias como preferidas de toda a trama. Elas foram editadas na sequência em que foram escolhidas, formando assim duas diferentes telenovelas reeditadas e mostradas para as famílias durante a dinâmica do grupo de discussão (GD).

Então, as cenas escolhidas seguem abaixo e foram escritas exatamente como as famílias descreveram no momento em que as elegeram:

\section{TVN- R - Família 1}

- Cena 1: Mirtes recebe chamado de Milú

- Cena 2: Morte de Gabriel

- Cena 3: Morte de Egídio

- Cena 4: Morte de guardiões: Feliciano

- Cena 5: Morte de guardiões: Delegado

- Cena 6: Luz aceita ser guardiã

- Cena 7: Acidente de Gabriel

A telenovela reeditada da Família 1 foi composta por sete diferentes cenas que totalizaram 20 minutos e 26 segundos. Todas as cenas têm relação direta com a trama

67 Ver em: https://natelinha.uol.com.br/mercado/2020/02/01/apos-fiasco-globo-nao-comercializa-osetimo-guardiao-internacionalmente-140171.php. Acesso em fevereiro de 2020. 
central da telenovela, que era a irmandade secreta composta por sete guardiões que tinham missão de proteger a fonte de poderes curativos e rejuvenescedores. Mais da metade das cenas são de mortes, e três delas aconteceram por causa do mistério que envolvia a fonte (Cena 3, Cena 5 e Cena 5), sendo que duas fazem parte do recurso de serial killer utilizado pelo autor, em que as vítimas são transformadas em objetos seriais, de consumo em série (GORENDER, 2010), e as "ideias convencionais de motivação (que predominam na ficção de mistério) não mais se aplicam" (MALMGREN, 2001, p. 179). Tal recurso proporcionou ao público a dúvida sobre quem era o assassino e qual era o motivo dos crimes, pois o único que se sabia era que os crimes tinham relação com a irmandade e com a fonte. Duas das cenas envolvem o protagonista da trama Gabriel e são sobre momentos ruins que o personagem passa, uma é sobre o acidente em que ele se envolve no primeiro capítulo da trama, mas que foi escolhida como última pela familia e que tem relação com a irmandade, e a outra é sua morte, no último capítulo, mas que tem a ver com sua vida amorosa, já que envolve sua ex-noiva e seu atual amor. Do total de cenas escolhidas, quatro delas têm algum elemento do realismo mágico apresentado na telenovela. Seguem as cenas:

Cena 1: Mirtes recebe chamado de Milú

Nessa ação, a beata Mirtes, rejeitada e sozinha depois de ninguém mais tolerar todas as maldades que fez, está dormindo quando o espírito de Milú, a esotérica, guardiã recém-assassinada na cabana em que Mirtes está dormindo, aparece para ela. $\mathrm{Na}$ aparição, Milú dá para Mirtes, sua rival durante toda a estória, uma missão importante que irá mudar o seu destino: assumir seu posto de esotérica na Cristalina (loja de Milú), e cuidar de seus bens. Foi a partir desse momento que Mirtes começou a se transformar em uma pessoa melhor e se redimir de tudo o que fez de errado com os moradores da cidade. Além disso, descobre que também tem poderes sobrenaturais como Milú. A cena foi uma das preferidas da família, principalmente pelo fato da beata ter se redimido. Mirtes era a defensora da "moral" e dos "bons costumes" da cidade em um tom de comicidade e não era a grande vilã da trama, pois, conforme o autor, esse posto era de Valentina. Porém, ao desenrolar da história, foi Mirtes que desempenhou inúmeras maldades perante diferentes personagens, recebendo da crítica e dos telespectadores o título de vilã da telenovela. Mas, apesar de todas as suas crueldades e 
humilhações que fez outras personagens passar, elas aprovaram a chance de redenção que Mirtes recebeu:

[...] porque a Mirtes era uma pessoa tão rígida, tãofanática religiosa e receber uma missão dessas no fim da novela que pudesse mudar ela sabe... [...] se tornou uma pessoa melhor, isso que eu achei bacana...que ela se redimiu, não que eu achei que ela fosse morrer, que ela tivesse que receber um castigo. Mas ao invés dela ser castigada, foi dada para ela uma missão que fizesse com que ela mudasse (Ana, 36).

Figura 25: Frame da cena em que Milú aparece para Mirtes

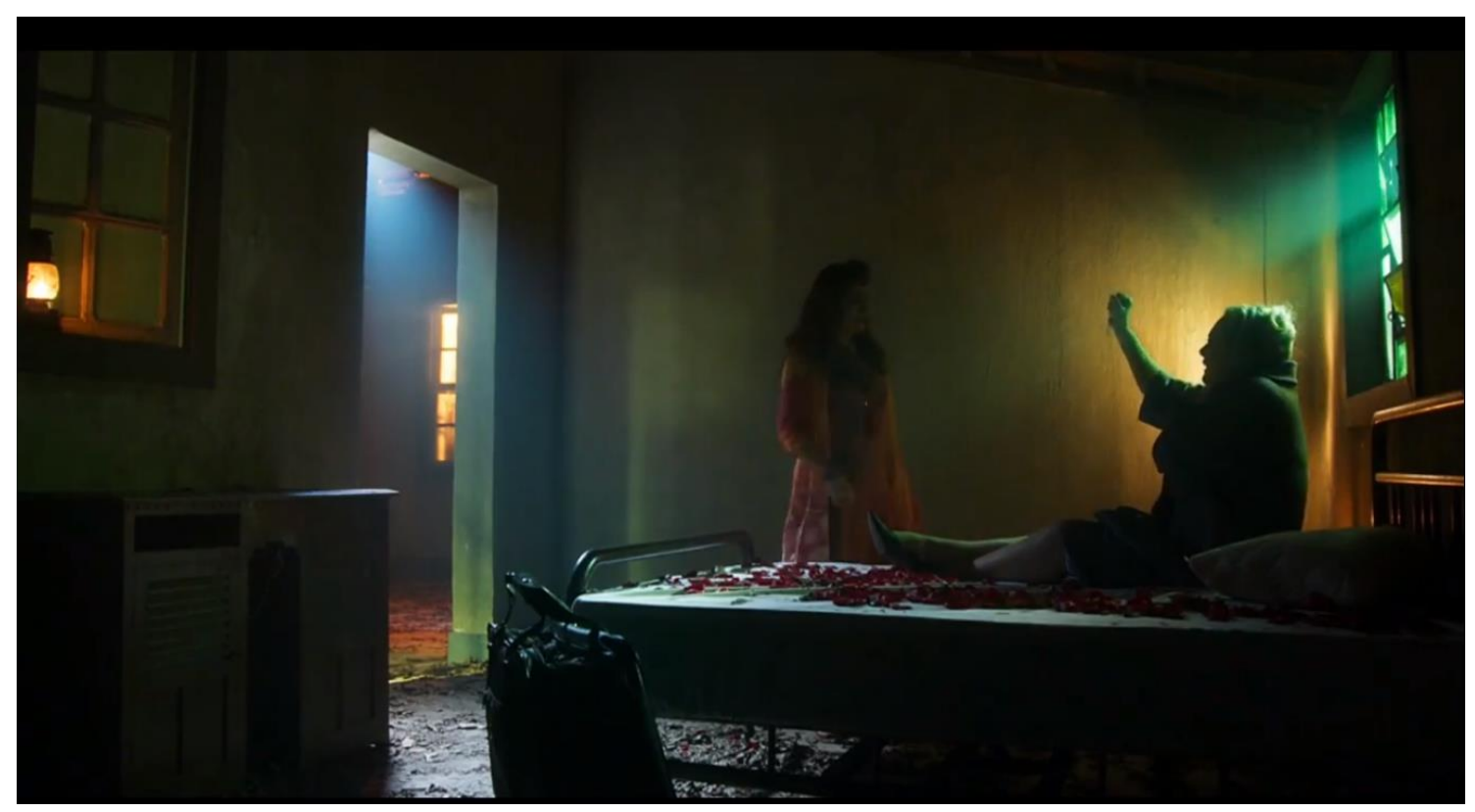

Fonte: Globoplay

\section{Cena 2: Morte de Gabriel}

A morte de Gabriel aconteceu no último capítulo da telenovela e teve grande carga dramática. Após o embate final para defender o casarão que abriga a fonte, Laura chega ao local e encontra seu pai, Olavo, morto. Desesperada, vai até outro cômodo da casa e encontra Gabriel em clima de romance com Luz. É nesse momento que aponta a arma para Luz com o intuito de matá-la, pois afirma que, por causa da mocinha, perdeu tudo o que tinha (se refere a Gabriel e ao pai, agora morto). Laura atira e Gabriel, para salvar Luz, se joga na frente, sendo atingido, e morre nos braços de sua amada Luz. Júnior, namorado de Luz e primo de Gabriel, Valentina e Murilo também fazem parte da ação. As receptoras entendem a raiva de Laura por ter sido abandonada no altar por Gabriel, 
mas não aprovaram o assassinato e nem morte trágica do protagonista, mesmo que tenha sido "para salvar a Luz", pois queriam que "ele tivesse um final feliz!", reafirmando a expectativa que vai ao encontro do roteiro tradicional do melodrama, em que o bem vence o mal e o "mocinho" fica com a "mocinha".

Figura 26: Frame da cena da morte de Gabriel

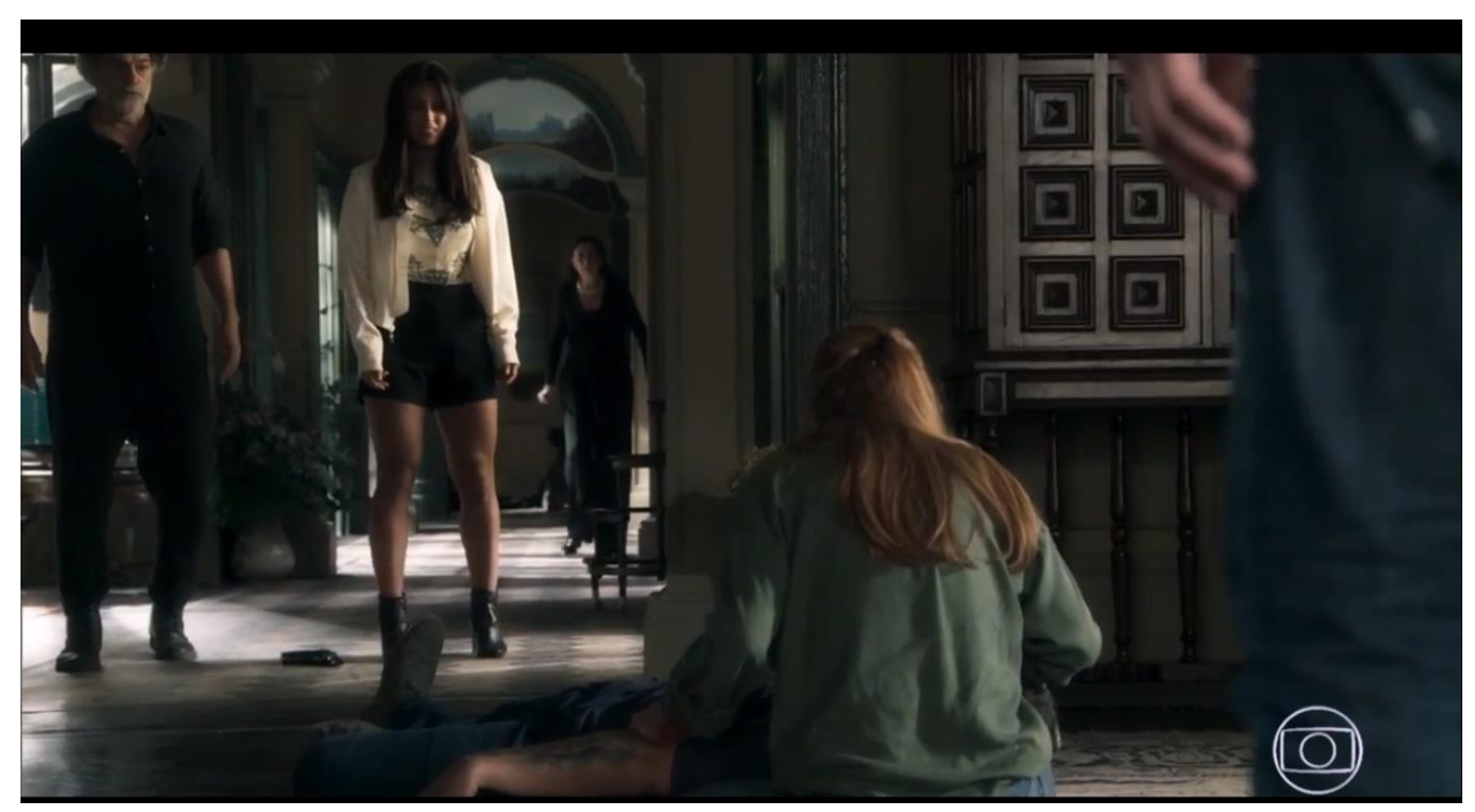

Fonte: Globoplay

Cena 3: Morte de Egídio

A morte do guardião-mor, Egídio, aconteceu logo no início da telenovela. Ele tenta manter em segredo o local onde fica a fonte de sua ex-noiva Valentina, mas não consegue. Nesse momento, Valentina também conta que ele é o pai do filho dela, Gabriel. Muito abalado, o homem se dá conta de que Gabriel é o próximo guardião-mor e cai da escada que leva até a fonte. O gato Léon está perto do corpo dele muito irritado com a situação, ataca Valentina. Para as receptoras, a morte foi causada por Valentina. 
Figura 27: Frame com a cena da morte de Egídio

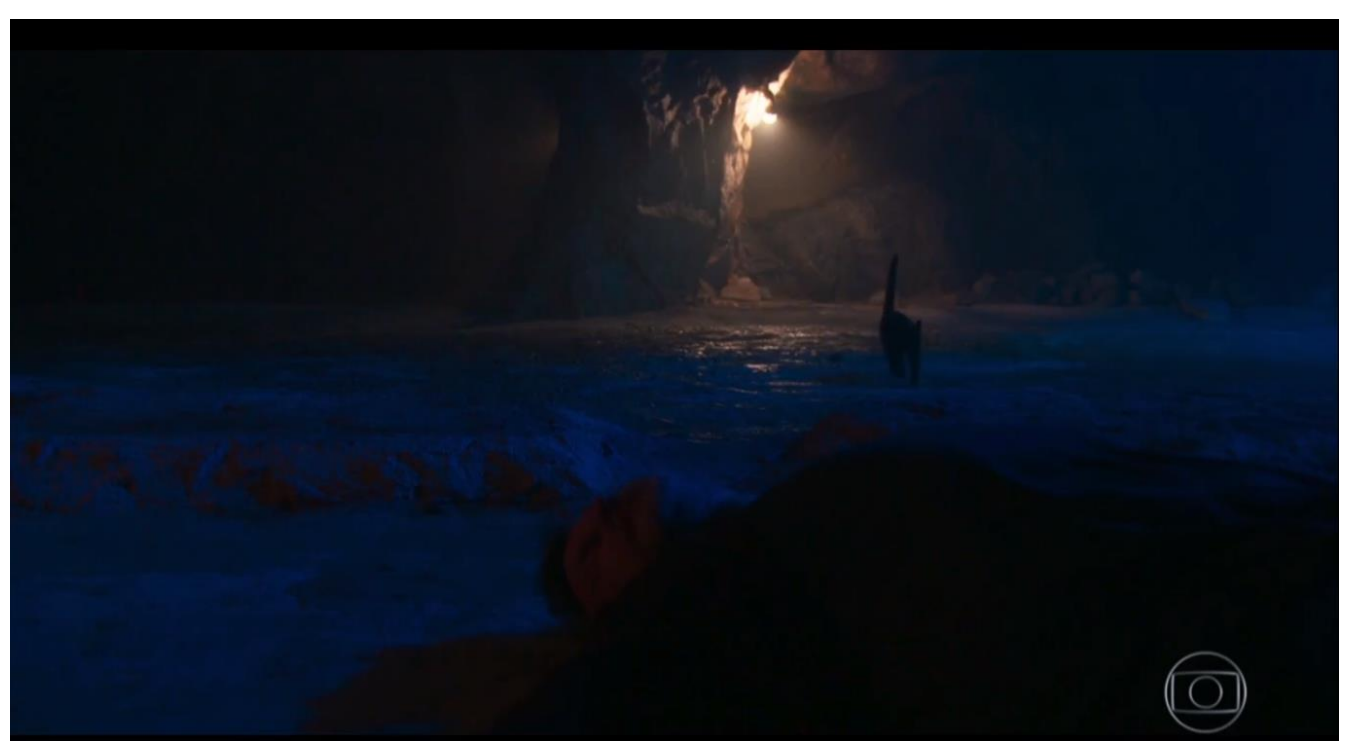

Fonte: Globoplay

Cena 4: Morte de guardiões: Feliciano

A primeira cena citada pelas receptoras com relação à morte dos guardiões, foi a que aparece Feliciano, minutos antes de ser assassinado e após uma noitada no cabaré. A cena inicia com ele caminhando, bêbado, à noite, no meio da cidade vazia, ao som da trilha sonora de Zé Ramalho, Entre a Serpente e a Estrela, e com folhas voando devido ao vento forte. A ventania sempre demarcava que algo misterioso e importante iria ou estava acontecendo na cidade. A sequência da cena é o padre Ramiro chegando na igreja com sua bicicleta, ele fica alegre por ter encontrado o mendigo Feliciano novamente dormindo na porta do local depois de dias sem aparecer. Mas, quando tenta acordar o amigo, percebe que ele está morto e sob seu corpo está o bilhete que indica que ele foi mais uma vítima do assassino de guardiões. Segundo as informantes, as cenas das mortes eram bem feitas tecnicamente: " a qualidade das cenas das morte era ótimo, porque parecia real" (Pâmela, 39), causando impacto, pois tais cenas "mexia muito com a gente". 


\section{Figura 28: Frame da cena da morte de Feliciano}

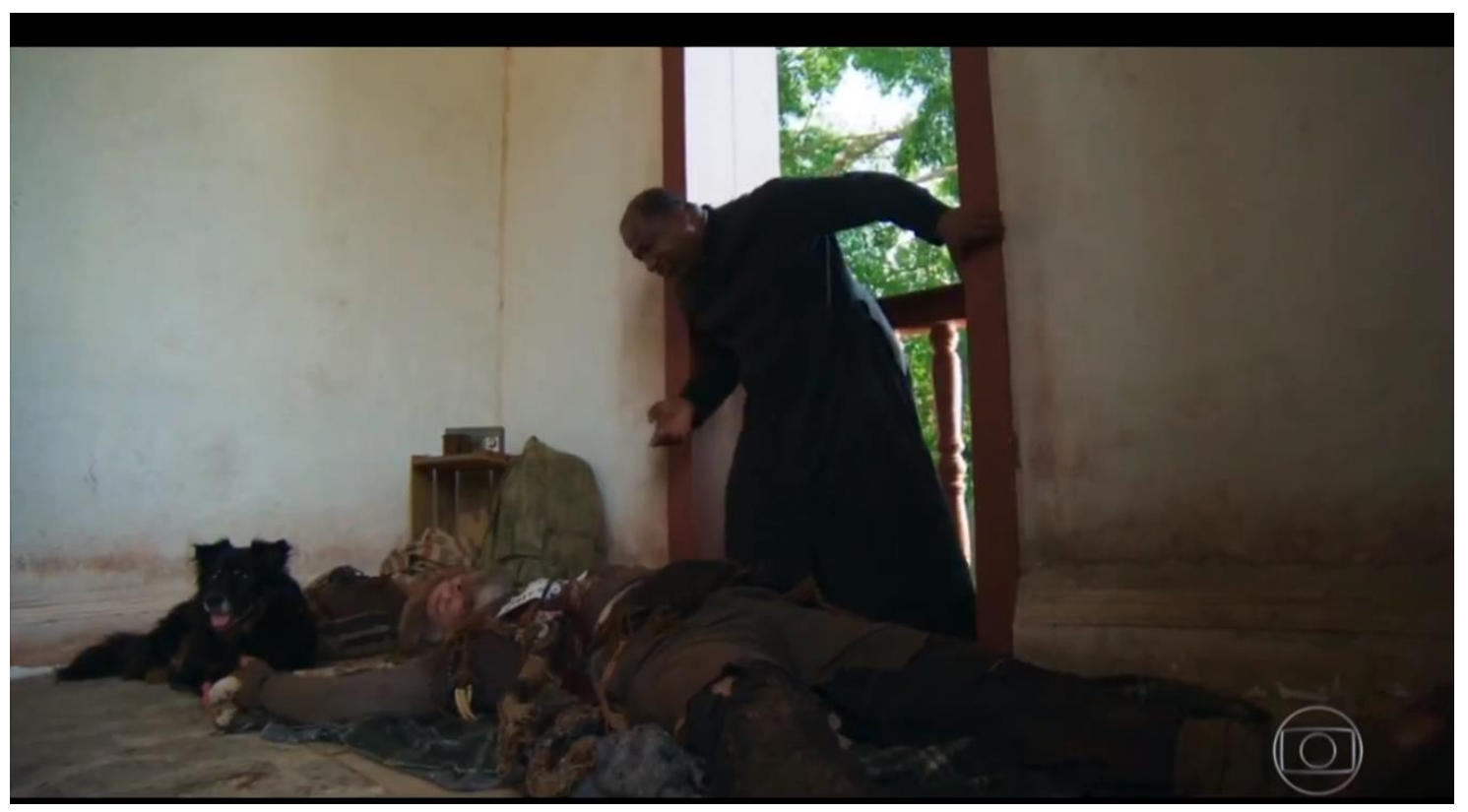

Fonte: Globoplay

Cena 5: Morte de guardiões: Delegado

Outra cena de morte dos guardiões escolhida foi a primeira de todas que foi ao ar, a do delegado Machado. Após a humilhação que passou no dia anterior em que, ao tentar proteger o casarão onde fica a fonte da invasão dos moradores de Serro Azul, eles o deixam só de calcinha e botas de couro, o delegado Machado se tranca na delegacia. Ele estava muito triste porque sua fantasia sexual tinha sido descoberta por Mirtes e contada para todos na praça da cidade. Assim, depois de uma noite inteira de tristeza e espera do marido, Rita de Cássia vai atrás dele na delegacia. É quando ela e o policial Peçanha encontram o delegado morto, com sangue no canto da boca e com um bilhete no corpo avisando que ele foi apenas a primeira vítima. Para as receptoras, a cena foi marcante porque foi a primeira morte, iniciando, assim, o mistério sobre quem teria matado e a razão, pois, em um primeiro momento, elas pensaram que a morte tinha relação com o preconceito que as pessoas tinham por terem descoberto o seu "segredo": "a gente achou que alguém tinha matado ele porque não aceitavam por causa da calcinha. A gente chegou achar que ela culpa da Mirtes... virou um mistério” (Ana, 36). 


\section{Figura 29: Frame da cena da morte do Delegado}

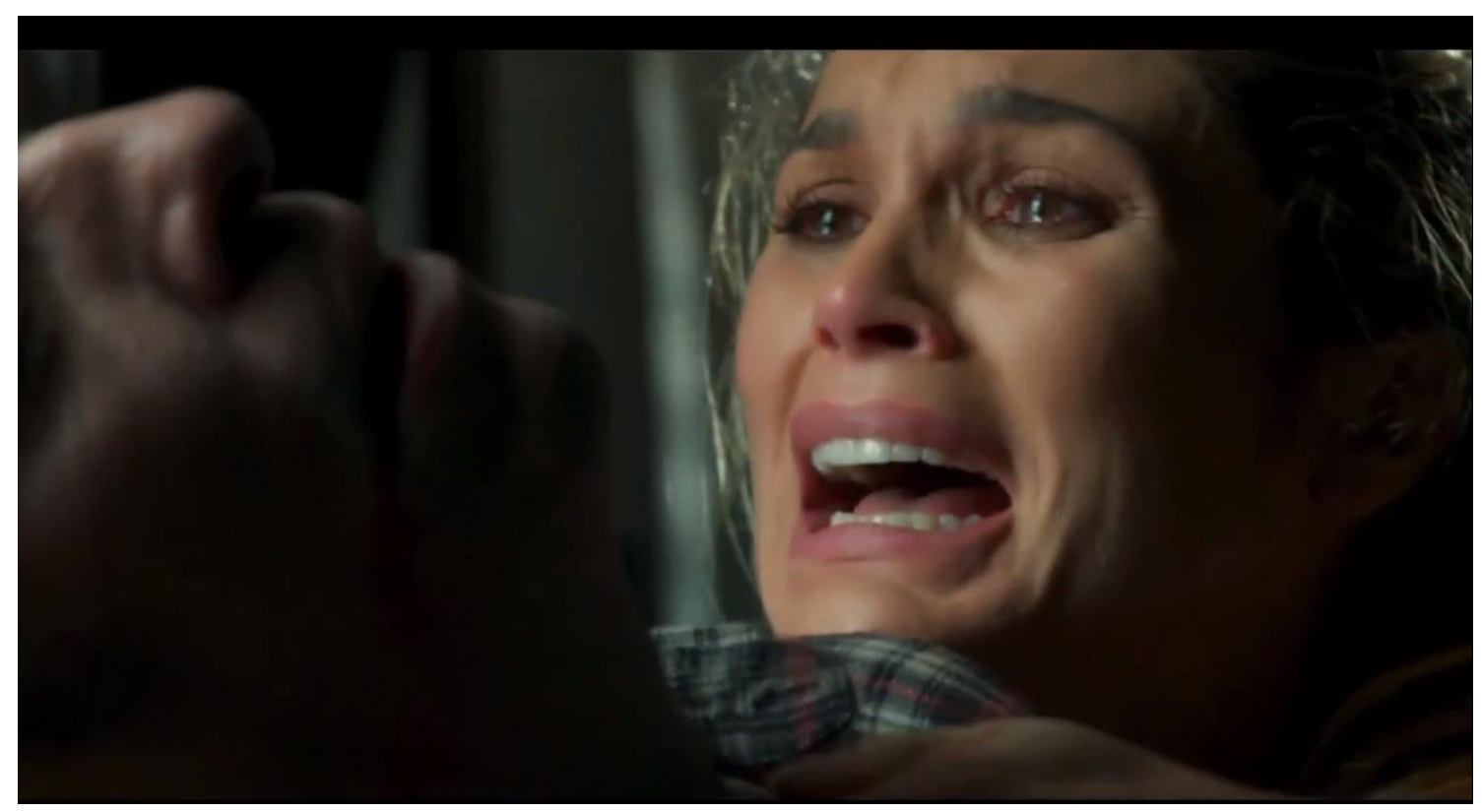

Fonte: Globoplay

Cena 6: Luz aceita ser guardiã

Na cena escolhida estão Luz, Gabriel, padre Ramiro, Murilo e Feijão. Eles se reuniram por conta de que, com as mortes dos guardiões, novos devem ser empossados. Gabriel escolheu Luz, Feijão e Murilo para ocuparem o cargo, mas precisa saber se eles aceitam ou não a missão. Com relação a esta cena, as receptoras criticam o fato da Luz também ter se tornado uma guardiã, uma vez que, para elas, a jovem deveria é se casar com o Gabriel, ser sua esposa e não se tornar uma protetora do segredo da fonte. Além do que, as informantes não entenderam que a Luz seria apenas mais uma guardiã, para elas, a moça ficou no lugar do Gabriel depois de sua morte, o que não é certo porque ele não deveria ter morrido e eles deveriam ter ficado juntos. Elas reafirmam, mais uma vez aqui, a preferência por histórias com matriz melodramática tradicional. 
Figura 30: Frame da cena em que Luz aceita ser guardiã

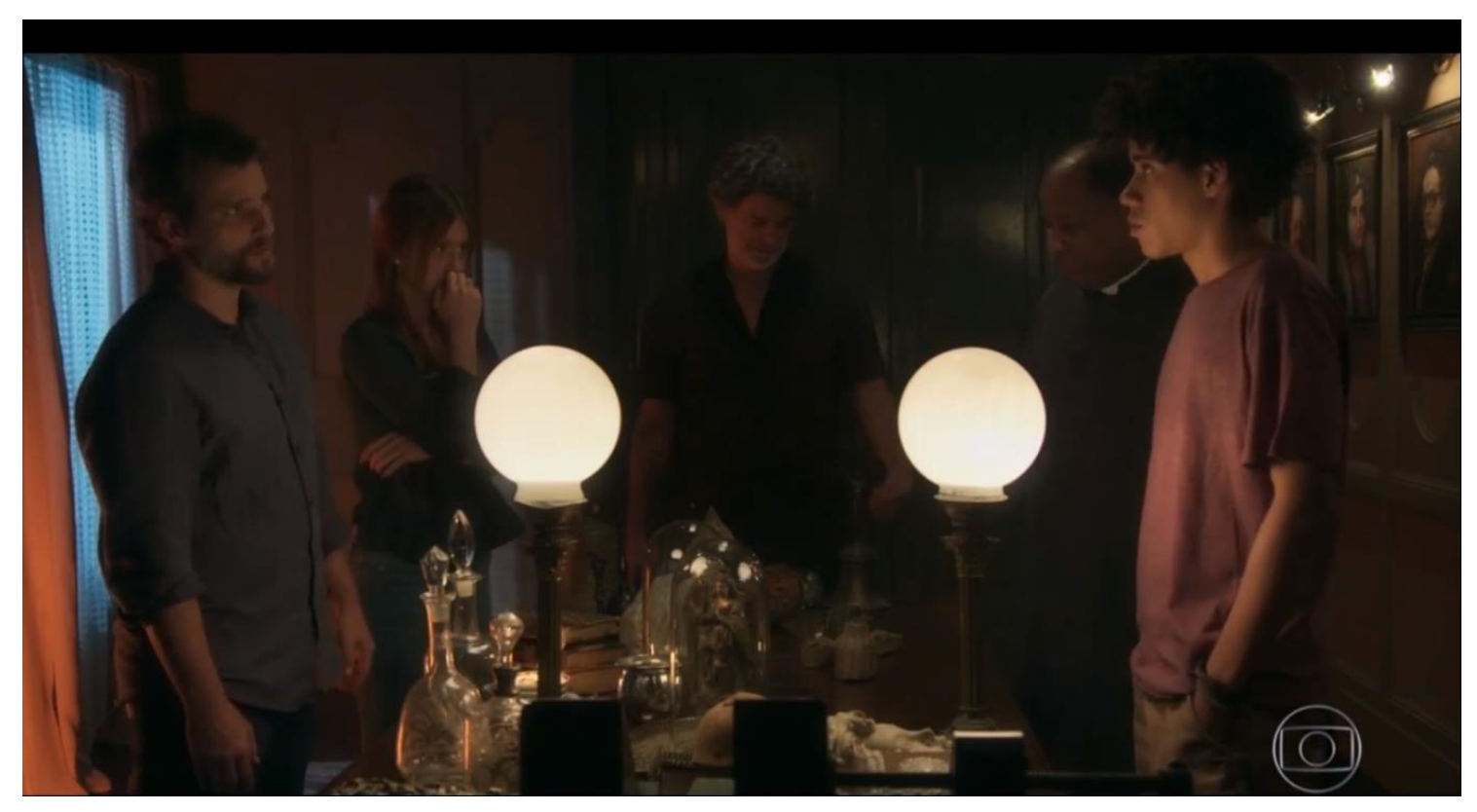

Fonte: Globoplay

Cena 7: Acidente de Gabriel

A última cena eleita, é a do acidente de carro com Gabriel próxima a sua chegada a Serro Azul, depois de receber o chamado de Léon. Como já explicamos anteriormente, o jovem se acidenta e é enterrado vivo pelo capanga da mãe porque este acha que o jovem está morto. É após ser enterrado que Gabriel aparece na guarda da cama de Luz, cheio de sangue e terra no rosto e nas mãos e pede sua ajuda. Foi então que a moça acordou, e mesmo assustada, segue Léon até encontrar o que seria, num futuro próximo, o seu amado. A cena foi uma das primeiras que mostrou como Aguinaldo Silva prometia trazer o realismo mágico na telenovela, com um toque de terror. Por isso, tal cena gerou expectativa dos telespectadores e da crítica de que a trama traria ao ar muito suspense e efeitos sobrenaturais, o que não se cumpriu com o passar dos capítulos. A cena foi considerada forte pelas receptoras justamente pelo fato de Gabriel ter sido enterrado vivo e ter aparecido para Luz, que foi salvá-lo no meio da noite. 
Figura 31: Frame da cena do acidente de Gabriel

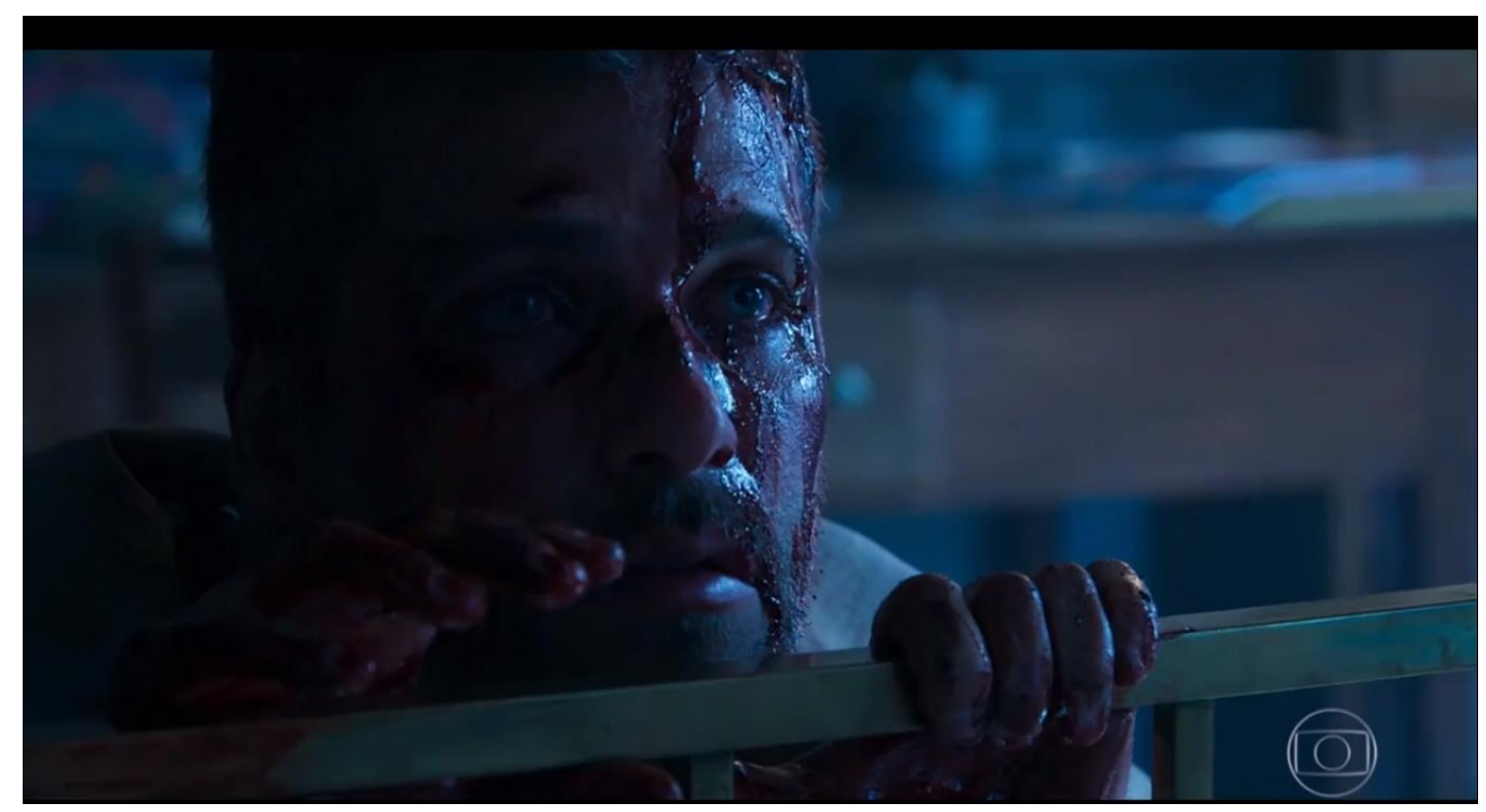

Fonte: Globoplay

Segue o link com o vídeo disponível da telenovela reeditada da Família 1: https $/ /$ drive.google.com/open?id=1Aj1 x4 zyohJRUaiS8 fwgov2cjfmlRmlVY.

A seguir, uma nuvem com as palavras mais faladas na telenovela reeditada da Familia 1: 
Figura 32: Nuvem de palavras TVN-R Família 1

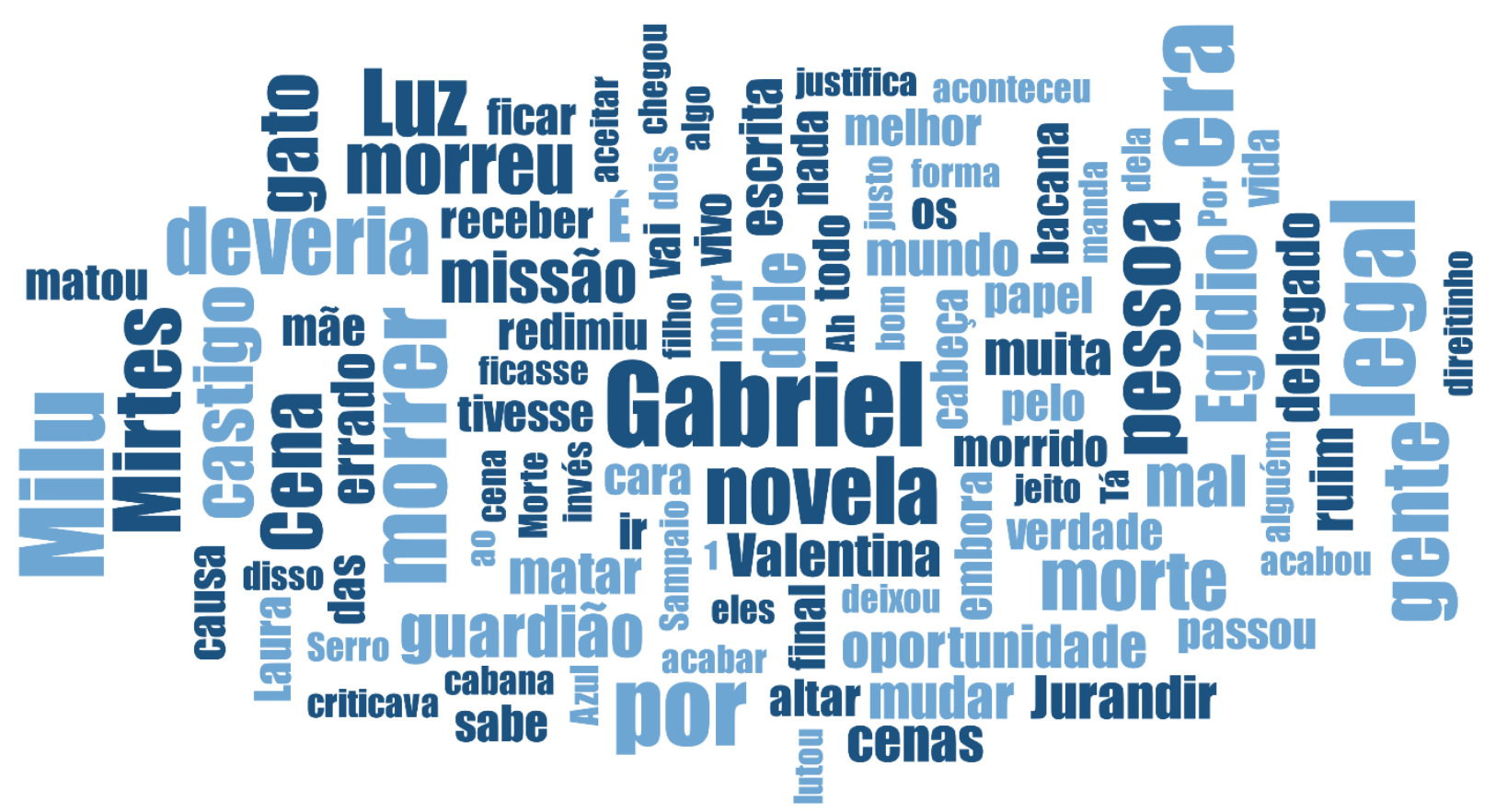

Fonte: Elaborado pela autora no Maxqda

\section{TVN-R - Família 2}

- Cena 1: León se transformando em homem

- Cena 2: Mirtes destratando alguém

- Cena 3: Bebeto dançando, afrontando Nicolau

- Cena 4: Rivalda tendo "ataques de machismo"

- Cena 5: Adamastor no bordel/pensão

- Cena 6 : Mistérios sobre assassinatos - morte do Delegado

- Cena 7: Mistérios sobre assassinatos - morte do Aranha

A Familia 2, por coincidência, também escolheu sete cenas como as mais importantes da telenovela. Porém sua dinâmica de escolha foi diferente, visto que cada cena, para as informantes, era tratada como assuntos. Ou seja, elas escolhiam mais de uma cena que ilustrasse os assuntos que gostariam de eleger como os mais marcantes da trama. É possível observar que, em apenas duas cenas, foram específicos na escolha, como nas dos assassinatos (Cena $6 \mathrm{E}$ Cena 7). O tempo total das sequências da telenovela reeditada da Família 2 é de 25 minutos e 12 segundos. Diferentemente da Familia 1, na 2, nem todas as cenas eleitas têm relação direta com a trama central da 
telenovela, ou seja, a irmandade secreta composta por sete guardiões que tinha missão de proteger a fonte de poderes curativos e rejuvenescedores. Nenhuma das cenas envolvem os protagonistas da trama, Gabriel e Luz; com exceção das duas de mortes dos guardiões e daquela de transformação de homem em gato e vice-versa, todas as outras são cenas que não são executadas pelos núcleos centrais da trama. A maior parte delas tem relação com o núcleo de Afrodite e Nicolau e sua familia. Apenas a Cena 1, partes de 6, têm elementos do realismo mágico e é sobre a transformação do gato em homem e vice-versa. Além disso, apenas duas sequências são sobre mortes, outra diferença das escolhidas pela primeira família. Assim, a maioria das cenas escolhidas, em vez de versarem sobre os fatos que compõem o melodrama tradicional, são sobre assuntos polêmicos e envolvem discussões que podem ser trazidas para o contexto atual que extrapola as da trama. Elas dizem respeito a machismo, preconceito de gênero e religioso, além de dramas familiares, demarcadas por diálogos fortes e situações tristes, em que a dramaticidade é, de certa forma, mais verossímil. Há apenas uma cena em comum entre as duas famílias.

Cena 1: León se transformando em homem

A primeira cena é a única selecionada que tem elementos do realismo mágico, pois é sobre a transformação do humano (Murilo) em gato León e vice-versa. A família escolheu duas sequências diferentes que representam essa ação: a primeira delas é quando Júnior, da rua, tenta atirar na janela do quarto de Luz para acertar Gabriel. O gato aparece, em forma de homem, e tira, rapidamente, a arma da mão de Júnior. Sai correndo e pula entre os telhados das casas da rua, e, logo na última sequência, já aparece em forma do gato Léon. Júnior fica perplexo com o que aconteceu. A segunda cena desse primeiro assunto é uma em que Murilo está conversando com Gabriel no casarão e, logo após a conversa, transforma-se novamente em gato Léon. Os ruídos da transformação e a dor que ela causa na personagem ficam explícitos por meio de sons e takes escuros de Murilo se contorcendo. Ambas as sequências que envolvem a transformação têm trilha sonora de mistério, contribuindo para caracterizar a narrativa fantástica/mágica da cena, pois ela "colabora, também na construção do gancho, cria o suspense, reforça a presença do mistério...” (LOPES, BORELLI e RESENDE, 2002, p. 301, grifo da autora). Mãe e filha escolheram as cenas porque estão relacionadas ao realismo mágico que chamou atenção delas para a trama. Inclusive utilizam o próprio 
termo técnico "realismo mágico" para designar a característica narrativa. Edna (52) achou a primeira sequência mais bonita: "era mais poética, teatral, deixava subentendido, essa segunda era de mutação mesmo. Era algo mais heroico, ele era um guardião que embora fosse castigado, ele tinha como a missão cuidar dos guardiães e proteger, principalmente, o Gabriel”. Marina (16), apesar de achar a segunda sequência perturbadora devido aos ruídos remetendo à quebra de ossos para que ocorresse a transformação de humano para gato, diz que deveria ser assim mesmo, dolorido, pois era um “castigo". 
Figura 33: Frame de León se transformando em homem - sequência 1

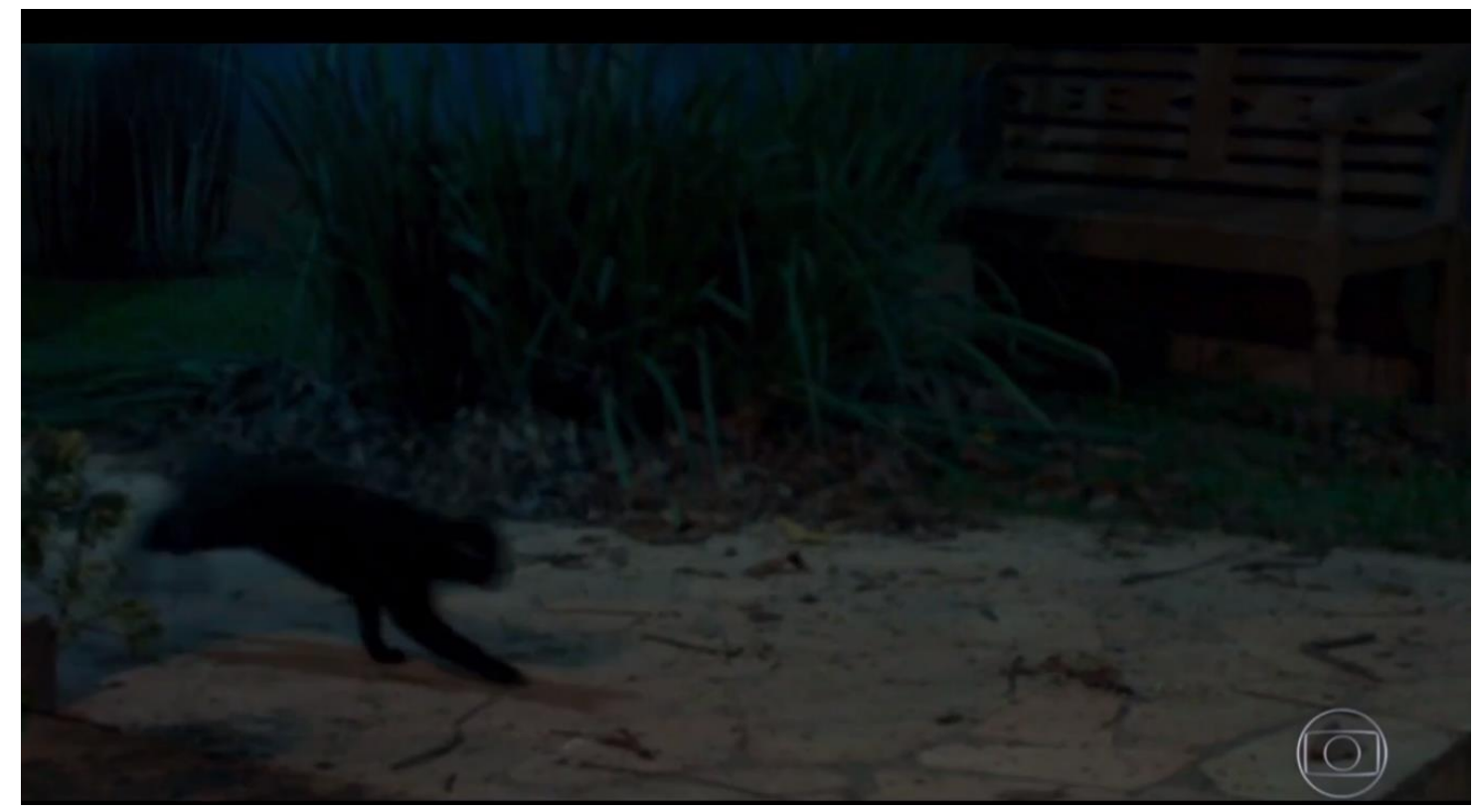

Fonte: Globoplay

Figura 34: Frame de León se transformando em homem - sequência 2

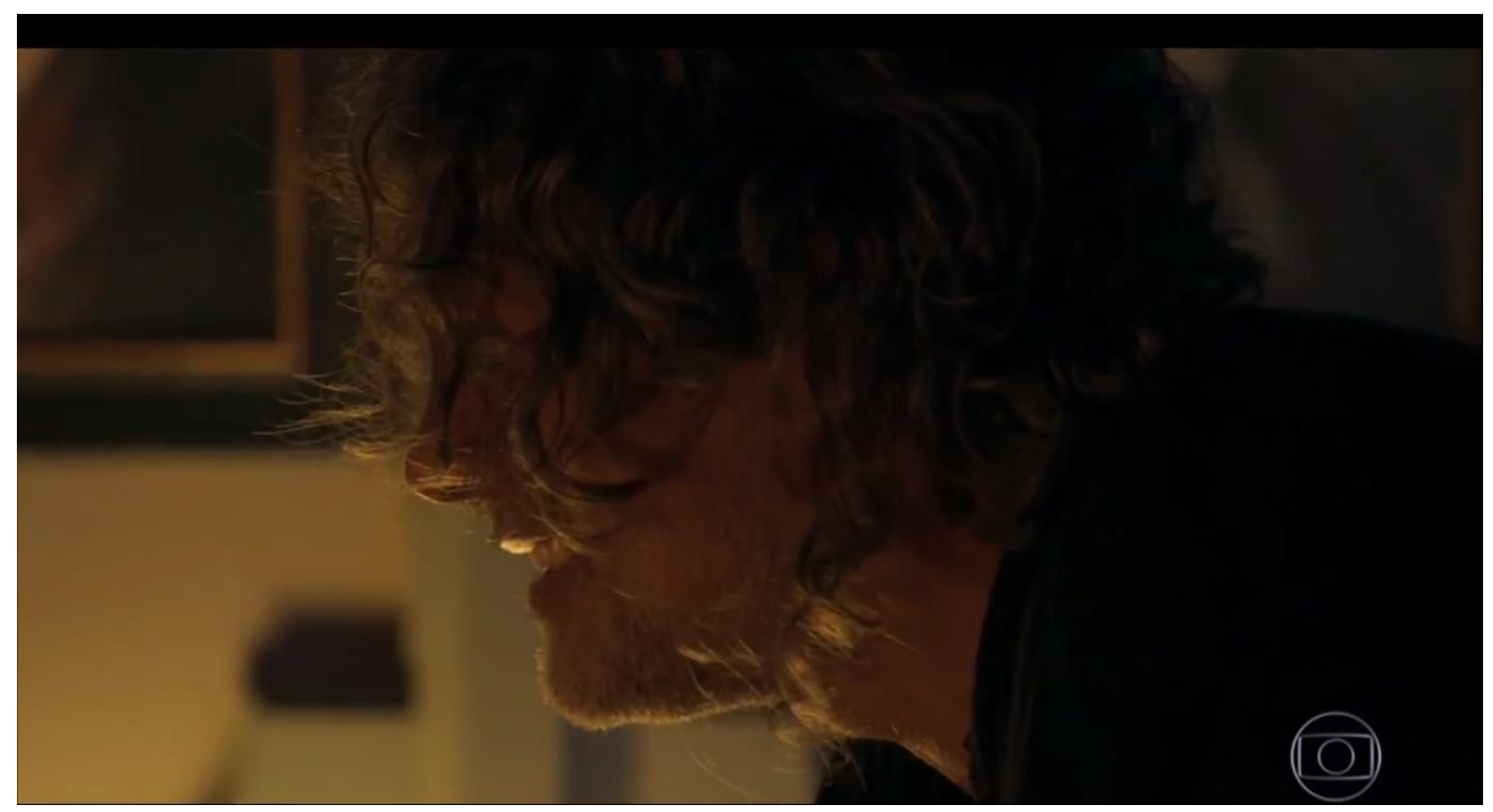

Fonte: Globoplay

Cena 2: Mirtes destratando alguém

A cena seguinte é sobre a beata Mirtes “destratando" algum outro morador da cidade devido ao seu preconceito com base nos preceitos religiosos. Na primeira sequência escolhida, estão a beata e seus três aliados discutindo no meio da praça com a 
cafetina Ondina e seus funcionários. A briga se deu porque Guilherme, o neto de Mirtes, tinha ido ao cabaré na noite anterior para insultar o pai, ex-genro de Mirtes e frequentador do local. A beata afirma que o menino estava sendo desviado pela "quenga safada" da Ondina e diz: " Não se pode dar um passo nessa cidade sem que se cruze com a pecadora!". Tal cena de embate (entre as religiosas e as prostitutas) também era comum na telenovela Indomada, mas esta relação não foi feita pelas informantes. A segunda sequência eleita é de Mirtes na igreja conversando com o padre, as beatas e o coroinha sobre o site Tarja Preta (que ela mesmo fez, mas que ninguém ainda sabia), defendendo as publicações para defender os "bons costumes" e a "moral" dos moradores de Serro Azul. Usa o exemplo da fofoca sobre o homem da cidade que usa calcinhas, criticando-o e afirmando que "as pessoas da fé, de família" agora são forçadas a aceitarem "esses homens que acham que tem o direito de usar peças íntimas do vestiário feminino". As receptoras concordam que as cenas de Mirtes eram carregadas de preconceitos e principalmente de fanatismo religioso, mas enxergam que eram exageradas e que : "A intenção talvez fosse botar numa personagem tudo mais assim, concentrado. Várias posições sociais sobre a religião colocar tudo numa personagem só” (Edna, 52). E, apesar de Marina (16) dizer que, em inúmeras vezes, a beata era "babaca", as duas concordam com o fato de que Mirtes era uma personagem cômica, exagerada, "o estereótipo da carola”, que colocava em jogo a oposição realirreal e a lógica do exagero proposta pelo realismo mágico. $\mathrm{O}$ cômico qualifica o gênero popular, então o gosto por ele é explicado pelo fato que "a comicidade, o riso compõem a essência da ficcionalidade popular" (BAKHTIN, 1987), pois: "Era tão ridículo que chegava a ser cômico, tipo assim... a gangue das putas contra a gangue dos santos!” (Marina, 16). 


\section{Figura 35: Frame de Mirtes destratando alguém}

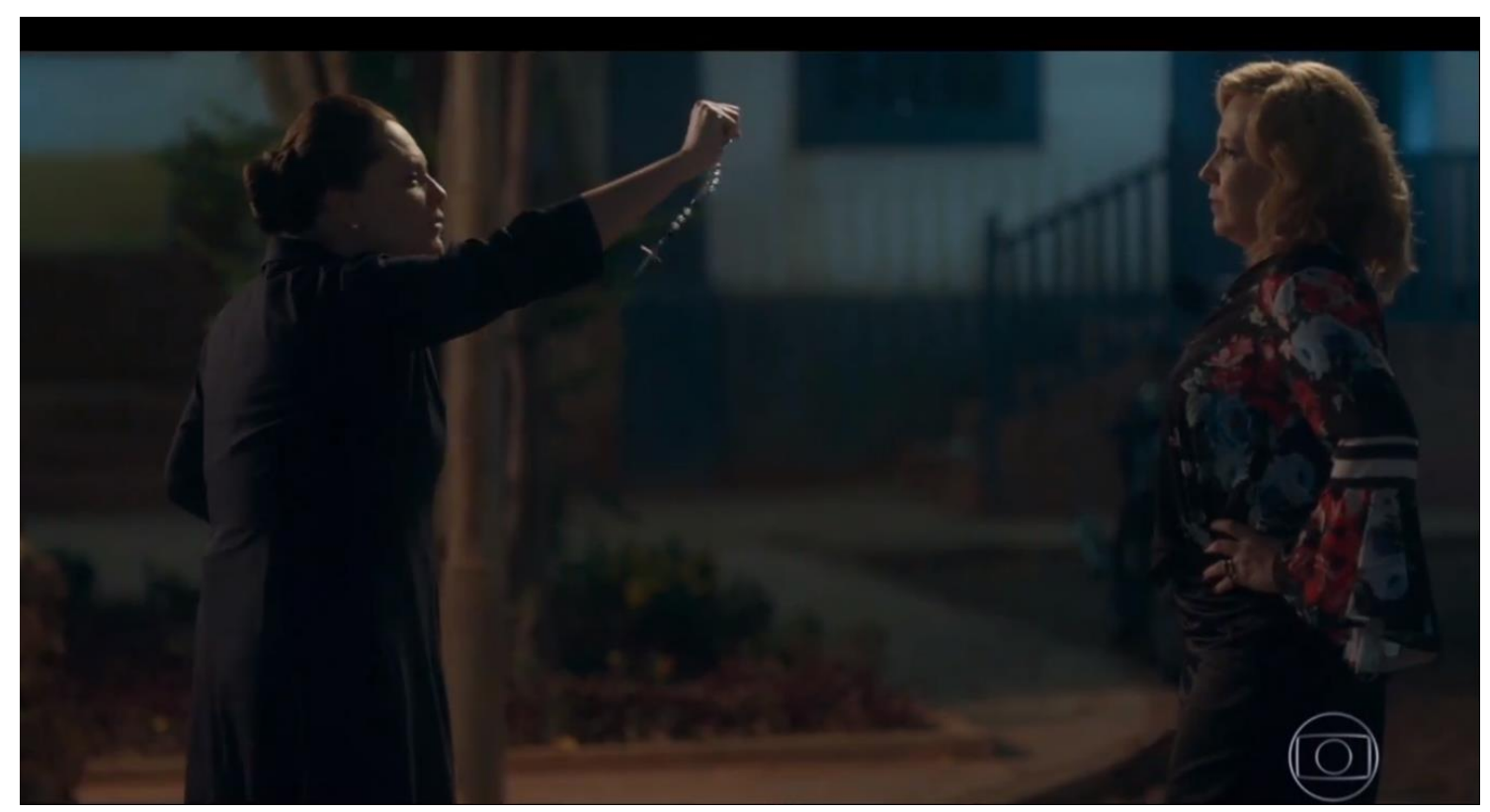

Fonte: Globoplay

Cena 3: Bebeto dançando, afrontando Nicolau

A Cena número 3, para a Família 2, diz respeito ao preconceito de Nicolau com o filho dançarino. A primeira sequência é pesada e sobre violência doméstica, pois Nicolau está agredindo a esposa Afrodite, e além de violência física, usa da psicológica, falando para esposa: "Você prefere ser puta do que viver comigo?". Os filhos Diana, Cristiana e Bebeto também participam da cena, que envolve também muito choro. Nicolau utiliza outras expressões de baixo calão pra se dirigir aos filhos e à esposa: "vou quebrar a tua cara", "viado", "filha sapato". Bebeto enfrenta o pai para proteger a mãe e as irmãs e o provoca dançando (fazia isso em outras cenas), já que Nicolau não aceita que ele tenha o tom e queria seguir a carreira da dança. A cena tem um alto grau dramático, até Nicolau, mesmo agredindo física e verbalmente a familia, chora muito com a situação. A segunda sequência, ainda sobre a relação delicada de Bebeto e Nicolau, acontece no trailer em que a família é dona. Afrodite ironiza se não é o marido o homem "machão" que gosta de usar calcinhas (fofoca espalhada pelo Tarja Preta), e ele, bravo afirma que não, e, como de costume na trama, utiliza palavras preconceituosas sobre homossexualidade. Durante a conversa, Bebeto passa dançando, e Nicolau fala para Afrodite que "sente vontade de vomitar" vendo o filho dançar. A terceira e última ação que compõe essa sequência de cenas sobre Bebeto afrontando o 
pai com a dança é a mais longa e aconteceu nos últimos capítulos da trama. É também uma cena dramática em que, após mais uma briga feia com o pai, o jovem está dançando na porta da igreja da cidade durante horas com o intuito de chamar a atenção do pai e fazê-lo aceitar sua opção profissional pela dança. Nicolau recebe a afronta e se desespera quando vê o filho desmaiar de tanto dançar. Ele o leva, no colo, para casa. As receptoras, apesar das cenas serem pesadas quanto a machismo, preconceito e violência, elas traziam reflexões, mas também eram engraçadas pelas coisas "absurdas" que Nicolau falava e porque Bebeto continuava dançando sem "dar bola” para o pai. Sobre a última sequência, elas afirmam acharem triste, mas, ao mesmo tempo, bonita, além do que "precisou chegar no final da novela para ele aceitar a dança do filho" (Marina, 16 e Edna, 52).

Figura 36: Frame de Bebeto dançando afrontando Nicolau

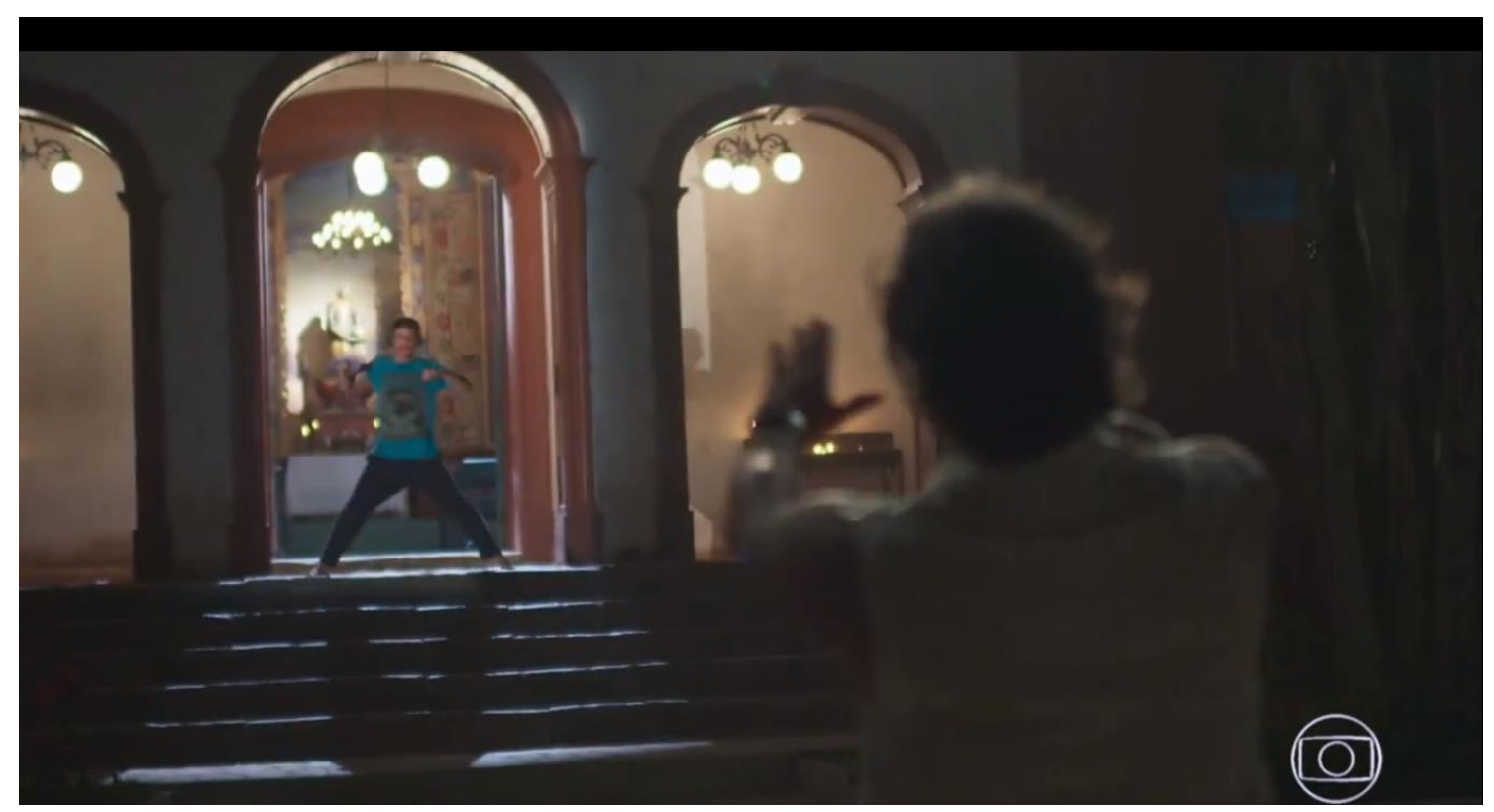

Fonte: Globoplay

Cena 4: Rivalda tendo "ataques de machismo"

Na outra sequência de cenas no núcleo de Nicolau e Afrodite estão as que Rivalda, a filha mais velha do casal, demonstra seu machismo. Na primeira delas, ela chega em casa quando a mãe está arrumando as malas porque decidiu se separar de Nicolau. Rivalda pergunta a razão e a mãe, muito triste, afirma que é porque o marido a agrediu. Rivalda friamente pergunta: "O que você fez para ele te bater?". Sem acreditar no que ouviu, Afrodite briga com a filha, que acaba confessando, ironicamente, que foi ela a 
causadora da discórdia entre os pais, pois contou ao pai que a mãe tinha colocado DIU para não engravidar, escondida do marido. O sonho de Nicolau era ter mais um herdeiro, um jogador de futebol. Na segunda cena estão Rivalda e a irmã Diana no quarto delas, e Rivalda, também em tom de ironia fala para irmã que vai conquistar o treinador de caratê de Diana, casar e ter filhos, e que será a única filha que dará orgulho ao pai, já que ele quer que as filhas casem e tenham uma "penca" de filhos. E acrescenta, não sou que nem "você que escolheu esse esporte de brutamontes". As duas discutem. As informantes se dizem chocadas e com "nojo" das atitudes de Rivalda afirmam que ela era pior que o pai e acrescentam: "eu acho mulher machista 20 vezes pior que homem machista" (Marina, 16). Mas, apesar da repulsa pelas atitudes da jovem, mãe e filha acabam fazendo uma reflexão sobre as razões que fizeram Rivalda ter esse tipo de comportamento, e ainda sobre o ato de escrever o texto da telenovela:

M: Porque, provavelmente, ela tinha ciúmes. O pai sempre quis um jogador de futebol, umatleta na família, e a Diana era a que estava mais próxima disso. Então, para se aproximar do pai ela começou a ter as mesmas atitudes. Julgar da mesma forma, por mais que seja desse jeito absurdo. Mas foi como ela entendeu.

E: Sim, a maneira que enxergou para poder ser aceita pelo pai. Ele não aceitava as meninas. Ah tadinha, na verdade! Ela entendeu que tinha que ser machista para o pai se orgulhar dela. Faz sentido. Mas será que na hora de escrever a novela eles pensam em tudo isso que a gente está pensando?

M: Acho que eles devem pensar, não devem escrever do nada as coisas. 


\section{Figura 37: Frame de Rivalda tendo "ataques de machismo"}

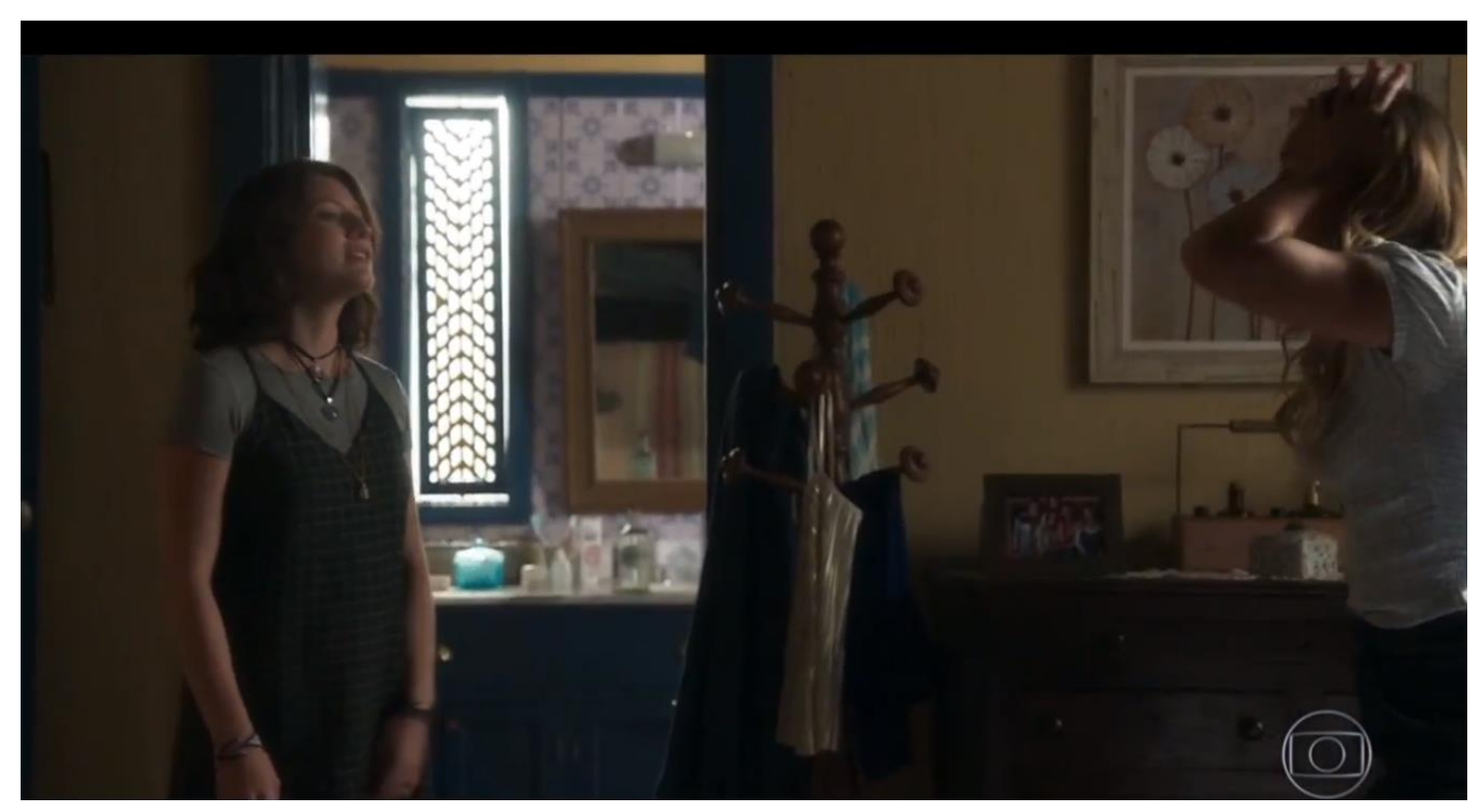

Fonte: Globoplay

Cena 5: Adamastor no bordel/pensão

As informantes escolheram outra cena que envolve humor. São duas sequências curtas de Adamastor, o gerente da pensão de Ondina. Na primeira, ele cobra de Matoso diária dupla por estar recebendo visitas de Marcos Paulo à noite, e fala que está cobrando a diária dupla puramente por questões monetárias, pois, por ser gerente de uma "casa de tolerância", não é moralista, referindo-se ao fato de que Marcos Paulo é uma mulher trans, inclusive o chama de "senhor que se diz senhoura". A ação seguinte é de Adamastor sendo irônico com Valentina enquanto ela, irritada, espera e pergunta por Feliciano. As receptoras declaram que escolheram as cenas porque Adamastor era uma personagem leve, engraçado. Elas gostam dos "trejeitos" dele e do seu estilo "clichê" de "cabaré francês, com aquela cigarreira" (Edna, 52) e com as "camisas estampadas de gola para cima” (Marina, 16 e Edna, 52). As duas preferiam as cenas em que, como por exemplo estas que escolheram, ele estava no cabaré ou na pensão e com as meninas, e não gostavam muito dos momentos sérios que passava com a Stella, esposa do médico Aranha. Eles se tornaram grandes amigos e, no final da trama Adamastor dou sêmen para Stella fazer fertilização in vitro. Fazem até, com base em suas literacias sobre telenovela, uma análise que permeia a construção do personagem: "Não foi ruim, mas 
foi diferente de toda a evolução dele como personagem. Eu até achei que ele ia ficar com o Matoso. Porque ele não tinha casal!” (Marina, 16).

Figura 38: Frame de Adamastor no bordel/pensão

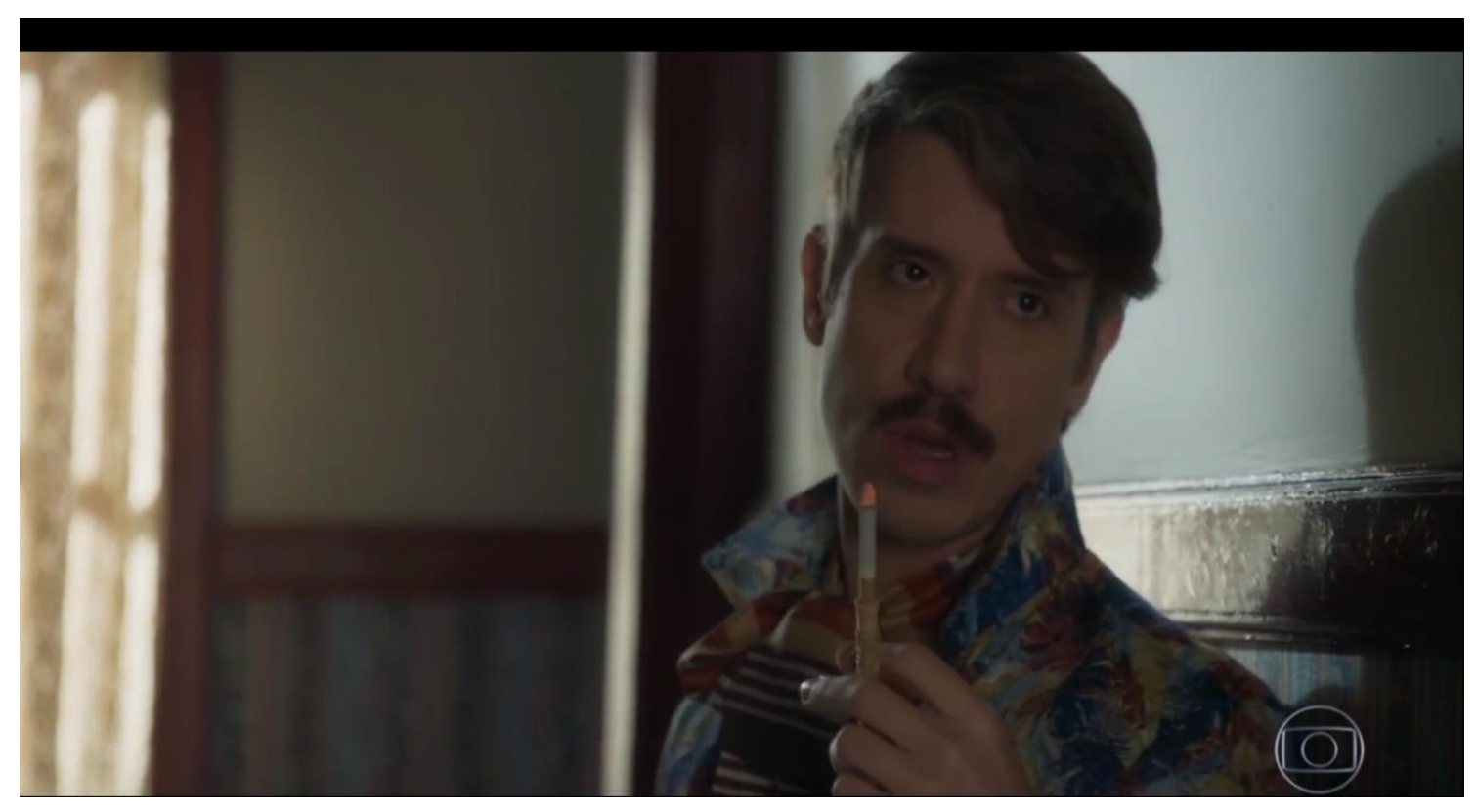

Fonte: Globoplay

Cena 6 : Mistérios sobre assassinatos - morte do Delegado

Assim como nas outras cenas eleitas como as mais marcantes da telenovela, a Família 2 selecionou mais de uma sequência para ilustrá-las. Elas têm relação com o mistério da fonte e da irmandade e com a história central da telenovela. Sendo assim, as cenas que envolvem o mistério das mortes dos guardiões iniciam com um take em que Judite, governanta do casarão em que está a fonte, vai até a ela e enxerga o espírito de Egídio, e ele dá uma ordem para mulher: "Faça o que tem que ser feito". Após isso, começaram os assassinatos na estória. Edna (52) conta que, assim que viu o primeiro assassinato, associou diretamente com esta cena, desvendando quem era o serial killer. Mas tanto ela quanto a filha fazem uma leitura diferente da cena, pois, em vez de pensarem que era o espírito de Egídio que apareceu, ressaltam que Judite que era louca e que a ordem de matar era apenas uma alucinação: "Sim, ele não era de ordenar muito, era o Gabriel que era mais autoritário. E não dá para entender porque matar os 
guardiães? Se quem não conseguiu proteger era só o Gabriel? Matando eles que a fonte não seria protegida mesmo" (Edna, 52).

Figura 39: Frame sobre mistério assassinatos -início de tudo

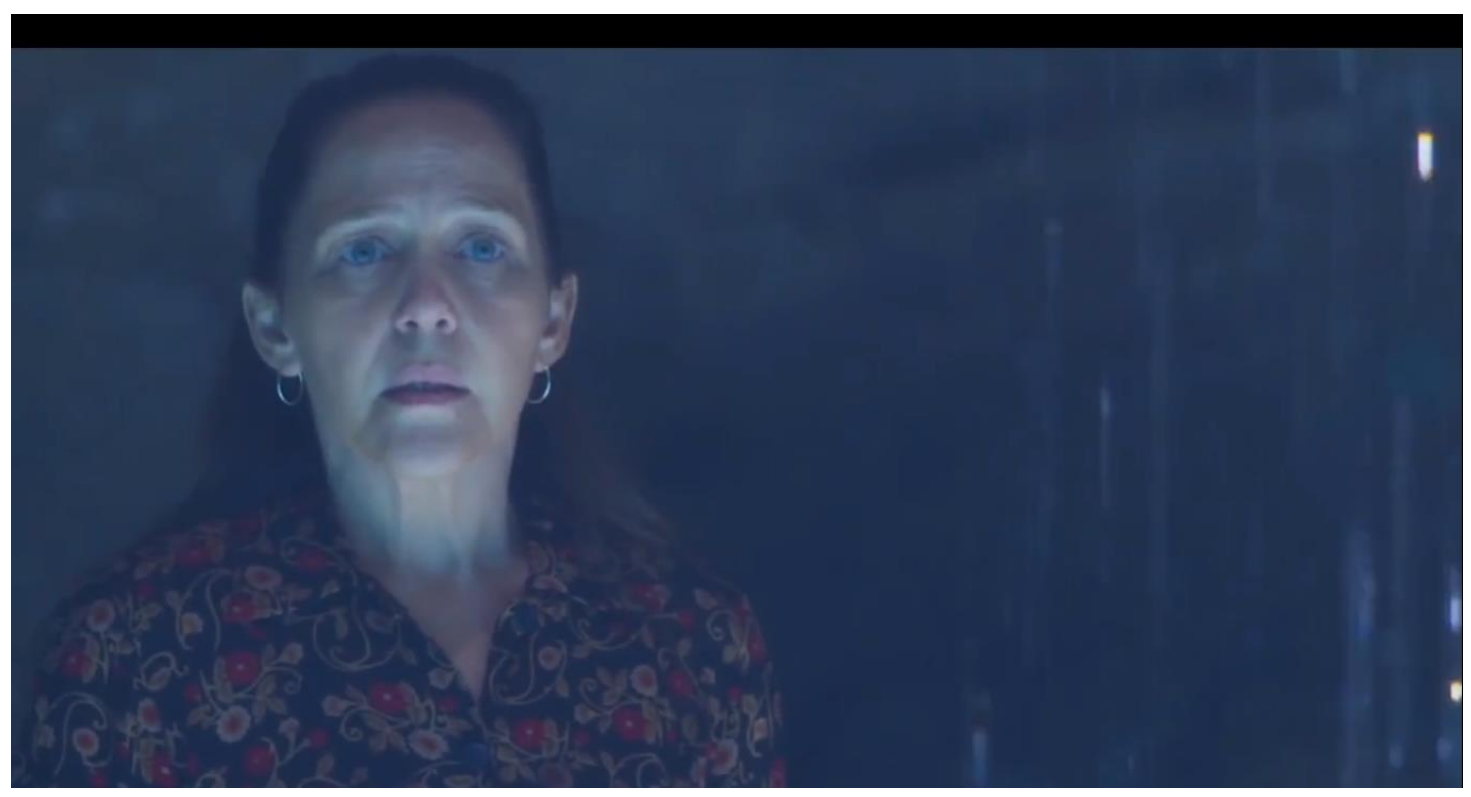

Fonte: Globoplay

A outra cena escolhida sobre as mortes dos guardiões é a cena em que morre o delegado Machado (Cena 6). Esta foi a única em comum com a Familia 1. A ação demarca a morte do primeiro guardião. E, assim como na outra família, esta também associou, em um primeiro momento, a morte com o fato da humilhação que o delegado sofreu por conta de sua fantasia em usar calcinha. A única diferença é que, na Família 1, conforme já mencionamos, as receptoras pensaram que Machado tinha sido assassinato por causa de preconceito em relação à fantasia e, na Familia 2, houve a ideia de que ele poderia ter cometido suicídio. Edna (52) comenta sua percepção sobre a cena, rindo: "Mas dai quando mostraram o papel que eu vi que não. Mas confesso que levei um tempo para entender de que 6 estavam falando!" 
Figura 40: Frame sobre assassinatos - morte do Delegado

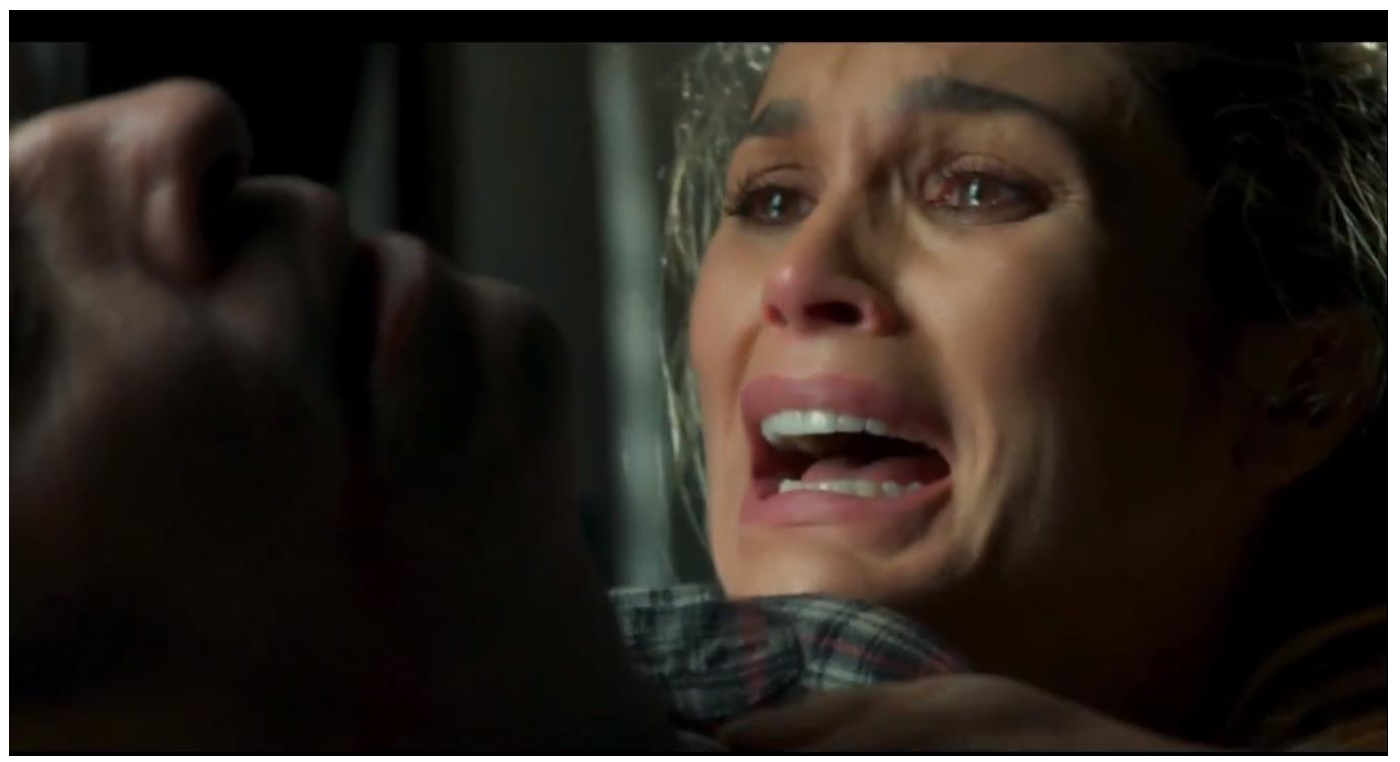

Fonte: Globoplay

Cena 7: Mistérios sobre assassinatos - morte do Aranha

A última cena selecionada segue essa lógica dos assassinatos dos guardiões da fonte, a morte é do médico Aranha. Ele foi o último a ser morto envenenado quando estava no cabaré da Ondina, sozinho, esperando supostamente Adamastor para uma conversa sobre a doação de sêmen que o gerente iria fazer para ele e sua esposa Stella. Mas tudo não passou de uma armadilha do assassino, que, ao deixar um whisky para Aranha tomar, faz com que ele beba o veneno, causando sua morte. Por ser a última, Aranha morre falando com o assassino: "Então era você o assassino da irmandade". Sobre isto, as informantes comentam que, mais uma vez, ficou claro que era Judite, pois deveria ser alguém que a vítima conhecia e que também sabia da irmandade. Mesmo assim, Marina (16) pensou que poderia ser o prefeito Eurico, expulso por mau comportamento: "A Marina achava que era o Eurico, não tinha cabimento ser! Não tinha sentido...aquele babaca ia conseguir fazer isso!” (Edna, 52). A mãe ressalta que gostava de assistir tais cenas porque, pelo menos o clima de mistério proposto no início e perdido ao longo da trama foi retomado e teve "um misteriozinho de novo, sobre 
“quem matou?" Eu gosto disso, dessa parte do suspense, de tu ficar pegando pistas" (Edna, 52). E faz relação com outras tramas que trouxeram a comoção em torno da pergunta: “quem matou?": “Legal essas coisas: Quem matou Salomão Hayala, Odete Roittmann! Isso as pessoas conversam... quem tu acha? Quem tu acha que matou?” (Edna, 52). Marina (16) pontua: "Mas não era a proposta de início da novela, esse é o problema, de início todo o enredo era da fonte e eles mudaram totalmente para os assassinatos porque não rendeu”.

Figura 41: Frame sobre mistérios sobre assassinatos - morte do Aranha

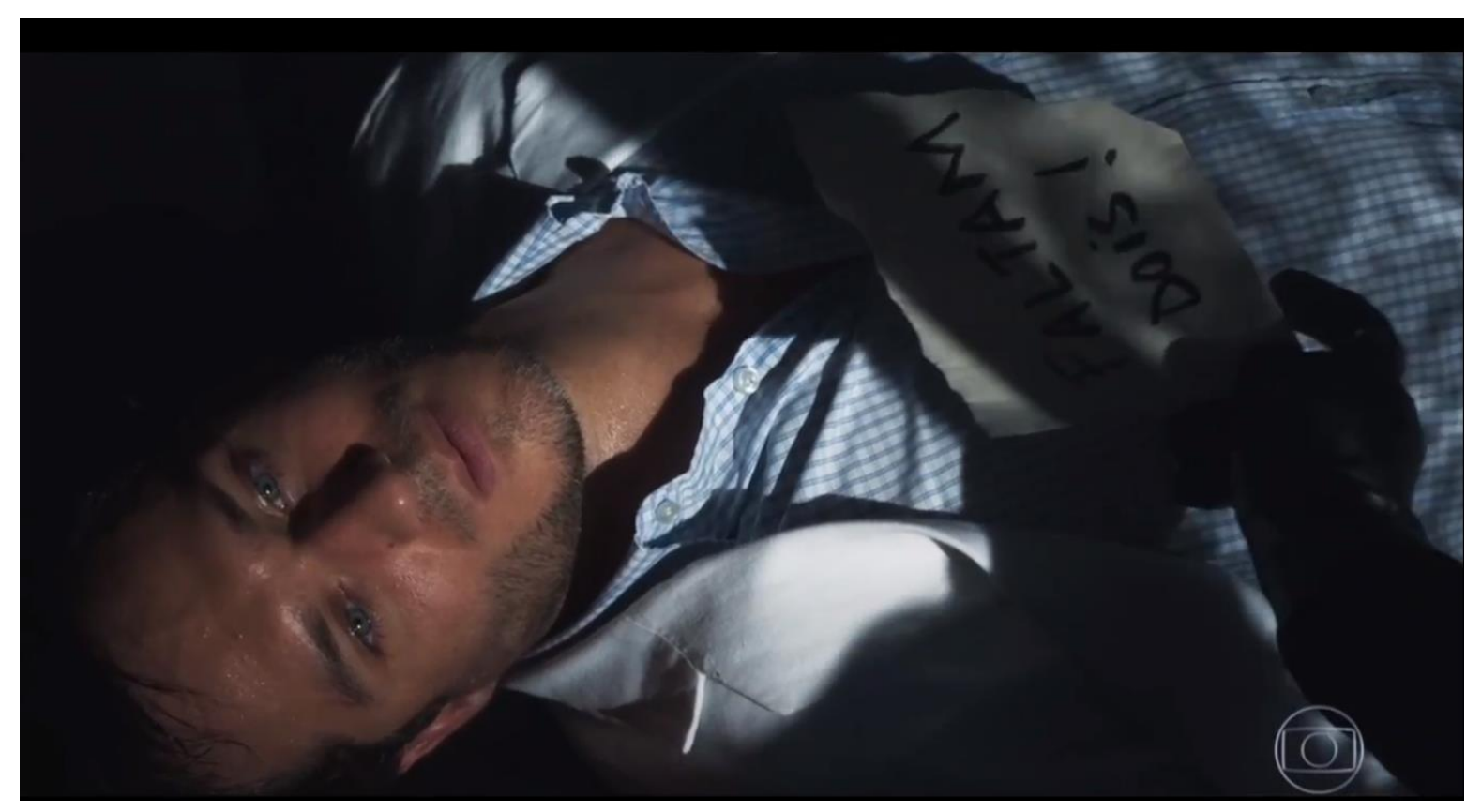

Fonte: Globoplay

Mesmo com os problemas de roteiro apontados por elas, as duas receptoras falam que as cenas eram tecnicamente bem feitas.

Segue então, o link com o vídeo disponível da telenovela reeditada da Familia 2: https $/ /$ drive.google.com/open?id=1F_4ADvGWhq4hACKG4EHI9hyzgLT1 DL6J

A seguir, uma nuvem com as palavras mais faladas quanto a telenovela reeditada da Família 2: 
Figura 42: Nuvem de palavras TVN-R Família 2

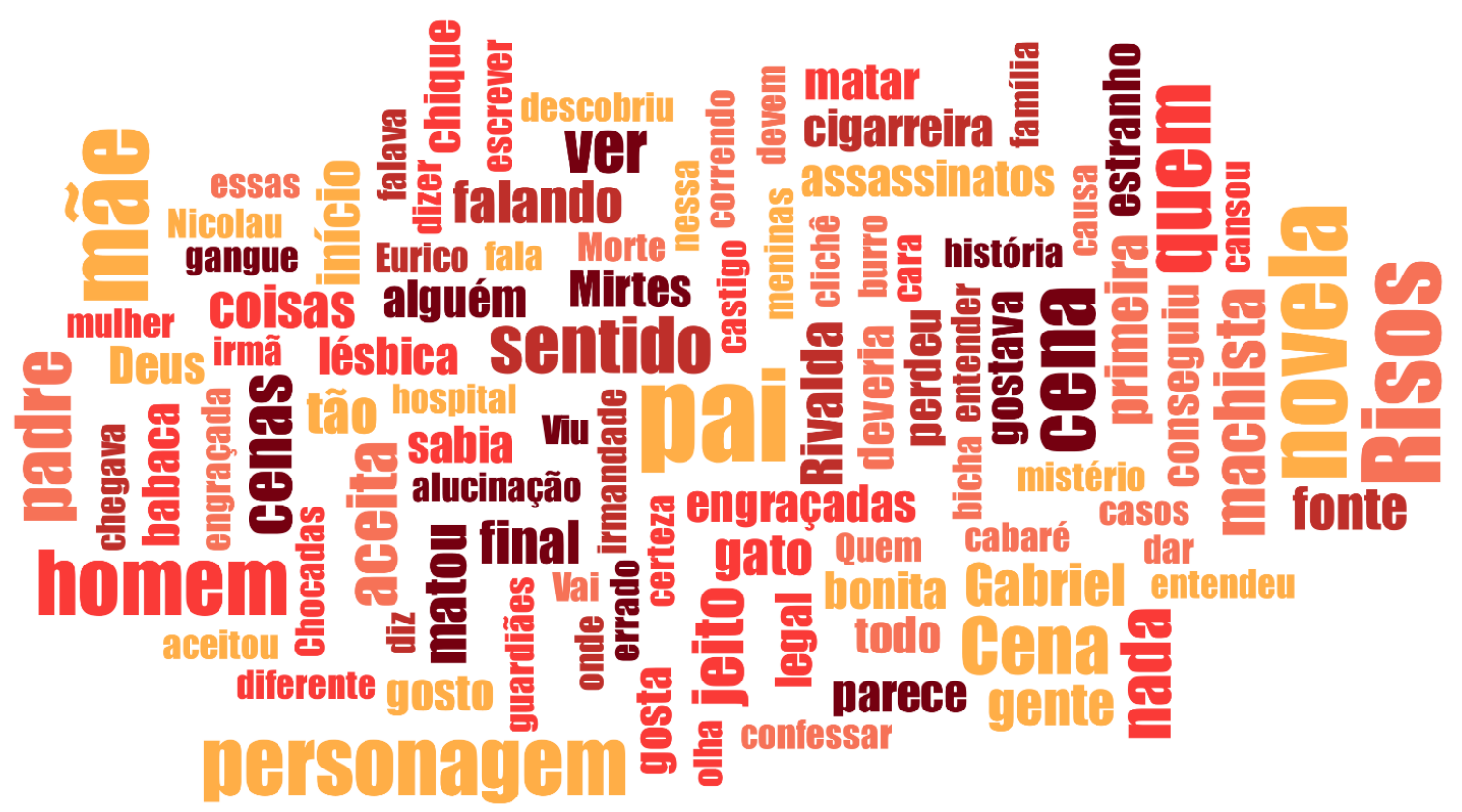

Fonte: Elaborado pela autora no Maxqda 


\section{Capítulo 7: As mediações na recepção da telenovela}

Neste último capítulo, fazemos a descrição e a análise interpretativa do que foi apreendido na pesquisa de campo quanto às mediações na recepção da telenovela. Assim, pontuamos e articulamos tais mediações entre si conforme a subdivisão feita a fim de operacionalizar a análise: as temporalidades articuladas com a sociabilidade no cotidiano familiar dos receptores estudados, as espacialidades com a ritualidade na assistência da telenovela e as sensorialidades associadas as identidades e cidadanias dos receptores. As tecnicidades em relação às narrativas, redes e ao gênero ficcional. A mediação de classe social perpassa todas estas mediações recém-citadas atuando como mediação estruturante.

\subsection{Temporalidades: a socialidade no cotidiano familiar}

As duas famílias pesquisadas não têm composição tradicional, pois não são mononucleares, formadas por um casal heterossexual, unido pelo casamento e criando todos seus filhos biológicos. Elas divergem do modelo conjugal. Uma é composta por consanguíneos colaterais, já que são duas irmãs e seus respectivos filhos (Família 1) e a outra monoparental, pois é formada por uma mãe a sua filha (Família 2). Ambas são chefiadas por mulheres, e, apesar de não adentrarmos teoricamente nas questões de gênero nesta tese, entendemos que seja importante pontuar este dado empírico, já que ele também é parte conformadora da visão de mundo, e, por conseguinte, das leituras que os receptores fazem da telenovela. Nossas duas familias informantes são o retrato da contemporaneidade em que as famílias têm diferentes constituições, visto que a "modernidade e que tem provocado uma ressignificação da própria noção de família" (FONSECA, 2002, p. 1). Ressaltamos, então, que as nossas famílias informantes têm formação diferente das famílias que fizeram parte da pesquisa de Vivendo.

Mesmo tendo configuração não hegemônica, a família ainda é unidade social essencial na vida dos informantes, visto que:

as relações familiares, de uma forma ou outra, parecem continuar ocupando um lugar de destaque na maneira em que a maioria de nós vemos e vivemos o mundo. Falar de família é evocar um conjunto de valores que dota os indivíduos de uma identidade e a vida de um sentido. Além dessa função simbólica, a noção de família -ligada à 
organização da vida cotidiana - ainda desempenha um papel pragmático na formulação de políticas públicas (FONSECA, 2002, p. 5).

A família atua como "referência simbólica" (SARTI, 1996, p. 3 e 33) dado que "os valores, a ética e a moral que conformam a visão de mundo social dos informantes são também, certamente, elaborados e transmitidos pela família" (PEREIRA, 2015, p. 102). É considerada "um espaço social (sistema de posições e relações de parentesco), um espaço cultural (história e dinâmica familiares) e como um espaço de mediação das mensagens [...]" (LOPES; BORELLI; RESENDE, 2002, p. 140) dos meios de comunicação. E, apesar do alargamento das fronteiras e dos espaços onde acontece a recepção e consumo de mídia devido à internet, a familia continua sendo, tradicionalmente, o local social onde acontece grande parte dessa recepção e consumo (TUFTE, 1997).

Portanto, investigar a recepção da telenovela no ambiente familiar foi relevante porque, mesmo com as novas tecnologias, a televisão ainda é um meio essencialmente doméstico e, por isso, sua recepção deve ser compreendida tanto no contexto doméstico e familiar quanto no que diz respeito às realidades políticas, econômicas e sociais (MORLEY e SILVERSTONE, 1991). É por conta disso que estudamos o entrelaçamento das sociabilidades familiares vividas no cotidiano com a relação dos receptores com a telenovela, pois tal produto cria um processo de extensão das esferas interpessoais para as relações sociais do cotidiano. Acrescentamos que, em se tratando de família, "o lar é a morada de sua vida quotidiana, e o aparelho de TV fortalece este sentimento" (LEAL, 1986).

\section{Família 1}

A Família 1 tem uma rotina diária intensa, pois, como já apontamos, o trabalho ocupa grande parte do dia dos informantes afinal, "ser da classe popular significa ter o tempo do cotidiano regido pelo trabalho e o não trabalho, ou seja, o horário de trabalho e o horário de folga, de descanso" (PEREIRA, 2015, p. 136). O tempo de descanso é também dividido entre atividades extras que contribuam com a renda familiar ou com atividades que agreguem conhecimento técnico ao trabalho já desenvolvido, no caso das duas mães, as tarefas domésticas e ainda entre algumas atividades de lazer, entre elas 
exercício físico, no caso de Ana (36), ou idas a bares e baladas para confraternizar com os amigos. Ana (36) sai à noite com maior frequência que Pâmela (39), pois a irmã mais velha escolhe apenas alguns dias do final de semana para se divertir fora de casa por causa de seu trabalho: "Final de semana para mim é sexta e sábado só. Porque daí na sexta eu tenho para descansar no sábado, e se saio no sábado, eu tenho o domingo" (Pâmela, 39).

As duas irmãs são solteiras e, diferente de anos atrás, os filhos já não são mais crianças, fazendo com que elas possam aproveitar as noites de lazer quando quiserem. Hugo (19), apesar de ser jovem, não sai muito, ele é "caseiro”, assim faz companhia ao primo Vinícius (12) quando estão sozinhos, ou então, há finais de semana em que o menino vai para a casa do pai. É ao falar das noites de lazer com as amigas que ficam explícitos alguns posicionamentos das irmãs quanto ao preconceito de etnia e distinção de classe social, em que a intenção é demarcar as diferenças da fração de classe que pertencem com as frações inferiores. Ao contar sobre os lugares que gosta ou não de frequentar, Ana (36) é categórica: “As menina falaram: Ah tem um lugar que a gente tem que ir, no Rio Pequeno num pagode. Eu falo: Menina, olha pra mim ...vê se eu tenho cara de ir pagode no Rio Pequeno? Ahh eu nessa parte eu sou assim”. Ela justifica a fala dizendo que o lugar "é uma biboca!" e que, além do mais, "detesta pagode" e os homens que vão ao local. A repulsa pelo gênero musical é justamente um dos marcadores da distinção, já que é associado "[...] no imaginário nacional a um contexto popular, absorvendo estereótipos específicos sobre as predileções, desejos, estilos de vida e hábitos culturais do "povo"'(TROTTA e ROXO, 2014, p. 4, grifo dos autores). Ao responder qual tipo de música escuta, ela diz que gosta de sertanejo (principalmente porque lembra da infância na Bahia), pop rock nacional e internacional. Quanto ao desdenho dos homens que vão ao local, Pâmela (39) afirma que é porque Ana (36) "não gosta de preto!" e acrescenta: "Mas tem homem de pele branca que é safado igual preto!" (Pâmela, 39), deixando claro que, mesmo que tenham fenótipo de etnia negra, ambas não se identificam como tal e ainda têm preconceito acerca desta etnia. E a discussão sobre a escolha do lugar para se divertir continua:

A : Sim, eu sei Pâmela! Tem muito cara no pagode de pele branca...não é isso...não é as pessoas...eu não gosto da música...humm, não gosto do jeito de quem tá lá. E também, se você quer encontrar um cara bacana aonde você vai encontrar... 
você vai encontrar um cara legal você tem que ir num lugar legal!

Desculpa... mas tudo combina com o lugar.

O posicionamento das irmãs reforça a associação já observada por Ronsini (2007b) de que o pagode é associado ao humilde/negro. Além do que, é possível observar que Ana (36) preza pela mobilização de seu capital social quando o assunto é os seus relacionamentos amorosos.

Ainda sobre os lugares que frequentam e o tipo de homem que encontram nestes locais, é preciso afirmar que ambas têm uma visão liberal quanto aos relacionamentos amorosos e a quantidade de parceiros com que se relacionam, declarando, inclusive, que utilizam a rede social de relacionamento Tinder para encontrar parceiros. Mesmo assim, Pâmela (39) possui uma visão um pouco mais conservadora que a irmã, prezando mais pelo amor romântico (GIDDENS, 1992). Ana (36) afirma que sai à noite para “paquerar”, Pâmela (39) não:

Eu não quero ninguém de balada, porque na balada hoje em dia os cara só vai para somar...às vezes pode ser coisa da minha cabeça e não é nem isso. Pode acontecer de conhecer um cara na balada, aí você namorar e casar como cara. Mas hoje em dia eu não me iludo mais. Eu não gosto de paquerar no rolê! Porque é fru strante, você fica como cara ali e se de repente ele não gostou, não curtiu você, de repente você vira para o lado ele tá ali beijando outra, eu não curto, acho chato isso. Então, se eu gostar dele a gente troca telefone e marca um dia fora dali.

Porém, há uma contradição quanto aos relacionamentos de Ana (36), pois, ao mesmo tempo que se diz "autêntica" e que faz o que tem vontade quando o assunto são os homens, ela afirma saber que é "terrivel" e que precisa "entrar na linha" por causa da quantidade de parceiros diferentes com quem se envolve. E quando afirma que, na verdade é romântica, vemos também uma predileção pelo amor romântico (GIDDENS, 1992): “Ai, eu queria viver uma linda história de amor... tipo nessa Espelho da Vida mesmo, achei linda essa história de amor, de passado...reencarnação. Será que um dia eu vivi ou vou viver isso?" e completa quanto sua preferência por finais felizes nas telenovelas:

Gosto da hora que tudo dá certo! Quando o casal apaixonado, que se ama se encontra, se reconcilia, se perdoa. Quando algum vilão é 
desmascarado, quando cai as máscaras da gente ruim. Quando tudo dá certo, final feliz!

Os filhos, de certa forma, reproduzem o comportamento das mães quanto à relacionamentos amorosos. Hugo (19) "é um menino reservado. Ele não é atirado assim. Eu acho que quando ele namorar vai ser para casar" (Pâmela, 39). A mãe acrescenta: "Ele é muito rígido assim com as mulheres. Porque ele fala: Cê acha que eu vou namorar essas meninas que ficam comigo na balada com copinho na mão, que fica beijando eu e beijando outro, eu não vou!” O jovem nunca namorou. Já Vinícius, apesar de ter apenas 12, já "fica" com as meninas, e como já comentamos no capítulo 6 , foi inclusive por causa de uma nova paixão que ele não participou das últimas dinâmicas da pesquisa de campo. Ana (36) diz que o filho "é danado que nem eu!" e que ele gosta de meninas mais velhas. O jovem confirma que prefere se relacionar com as "menina com mais jeito de mulher, sabe? Tipo com uns 15 anos, não gosto de menina da minha idade, pequena!'. Ele passa horas no telefone celular conversando com as "crushes". Além do mais, é categórico quando conta que só gosta de meninas, e que, um dia desses, um colega deu em cima dele e ele deixou bem claro que respeita, mas não "gay". Mas a mãe não autoriza o filho a utilizar a rede social de relacionamento Tinder, como ela e irmã fazem porque "é coisa de adulto".

Foi possível constatar que os membros da familia transitam entre aspectos liberais e conservadores tanto em suas relações quanto em seus ideais amorosos e ainda no que diz respeito ao que veem nas telenovelas, pois não concordavam com as cenas de sexo mostradas em $O$ Sétimo Guardião: "Acho que não é propício para o horário porque é pesado, tem criança acordada. Acho que é desnecessário” (Ana, 36). O filho se sentia constrangido com tais cenas, principalmente quando estava assistindo junto com a mãe e a tia. Mas afirma, envergonhado, que, quando está na casa do pai, assiste sua série preferida na Netflix: "Não liga por nome não... chama Sex Education, se passa numa escola e um meninos a mãe é terapeuta, então ele aprende e dá dicas de sexo para os colegas" (Vinícius, 12). Ele só assiste na casa do pai, porque apenas lá tem acesso a Netflix. Quanto às outras atividades de lazer, o jovem gosta de ir na casa dos amigos, "dar uma volta" no shopping com eles e de jogar futebol.

Pâmela (39) comenta que, apesar de não mostrarem tão explicitamente o sexo nas cenas, acha que elas não deveriam aparecer e principalmente aquelas entre 
Valentina e Murilo, porque "Não tenho preconceito com idade, mas acho exagerado para uma mulher madura como ela”. Ela e a irmã também não aprovavam as cenas em que Laura aparecia "pegando lá com a outra moça, a secretária da Valentina”, diziam: “credo, que nojo!”.

Quanto às relações de gênero, Ana (36) e Pâmela (39) reconhecem em Nicolau um homem "machista" e "inseguro" e dizem que ele é o retrato do homem brasileiro atual. Mas, apesar de pontuarem a questão, por inúmeras vezes, não aprofundam as discussões sobre tais relações de gênero mostradas na telenovela.

Quanto às relações familiares, a Familia 1, dentro do espaço doméstico, vive em harmonia, Ana (36) e Pâmela (39) cooperam uma com a outra em tudo, das tarefas domésticas, despesas com a casa e até na educação dos filhos. E quando têm alguma discussão, por conta de pensarem diferente, logo conversam, as duas irmãs não costumam brigar. Mas Ana (36), rindo, compara a irmã com uma personagem da telenovela: "tem um pouquinho de Mirtes! Não de fazer maldades para as pessoas, mas de ser curiosa e de falar as coisas na cara, que nem a Mirtes sem medir as palavras”. Pâmela concorda, porque afirma não ser "fingida", que prefere sempre falar a verdade a mentir sobre alguma situação. Além disso, diz ser curiosa porque gosta de "ver sobre a vida dos outros nas redes sociais". E dão um exemplo do que aconteceu no último dia dos namorados com alguns posts na rede social Facebook: Pâmela (39) se comparou com Mirtes e seu site de fofocas sobre Serro Azul:

A: Nos dias dos namorados todo mundo postando declarações de amor e aí ela postou: Gente, gente, vai com calma nessas declarações aí...hoje é dia dos namorados não é dia 1 de abril não! (Risos das duas). Porque ela sabia de um monte de traição!

P: Nossa as menina queria me linchar no Facebook! Daí eu falei: Não queira que eu faça print de site de relacionamento e poste aqui né? Então vão ficar tudo quietinha e vai apagar os comentário maldoso que fizeram aqui embaixo! Quando eu olhei não tinha ninguém mais lá! (Risos das duas).

Ao analisarmos a família extensa, ou seja, ou outros familiares que não moram na casa, mas frequentam o local, como os irmãos e irmãs e seus respectivos companheiros e a mãe, é possível observar alguns conflitos entre eles, em que as irmãs não são diretamente envolvidas, apenas para ajudar "os ânimos a se acalmar". Ou então, em um caso elas se envolvem diretamente, que é o que diz respeito à irmã e seu marido. 
Ana (36) não concorda que Pâmela (39) gaste boa parte do seu dinheiro comprando mantimentos e roupas para a irmã e sua filha pequena, visto que o cunhado trabalha e, segundo ela, gasta o dinheiro com outras prioridades: "Não tem dinheiro para comprar leite para o filho e tava tomando uma cerveja Heikene que custa 5 reais", ela diz que a irmã e o cunhado "se aproveitam da bondade da Pâmela". Mesmo assim, é categórica ao afirmar que se a família da irmã realmente estiver "passando dificuldade", ela não hesitaria em ajudar:

Quando eles não tinha mesmo eu jáfui, saí da minha casa comprei as coisas e levei lá. E se um dia não tiver trabalho, eu faria de novo. Mas trabalhando...pô pera aí...todo mundo trabalha aqui! Todo mundo acorda cedo, chega tarde...eu sei que eu dou duro e ela também...todo mundo sabe disso (Ana, 36).

Esta cooperação entre os irmãos, irmãs e a mãe das informantes reforça um fato já observado em outras pesquisas sobre famílias de que

No Brasil, há indicações que a rede consangüínea nunca deixou de ser relevante. A importância da parentela extensa aparece com nitidez em grupos populares onde, diante das difíceis condições de vida e freqüiente separação conjugal, as redes de ajuda mútua tornam-se indispensáveis (SCOTT, 1990; SARTI,1995) (FONSECA, 2002, p. 8).

Além do que, apesar da "correria" do dia a dia, os laços que unem os irmãos e todas as dificuldades enfrentadas pela família no passado, na Bahia, fazem com que esse sentimento de apoio que uns dão aos outros esteja presente e caracterizando a relação familiar.

Ana (36) tem uma boa relação tanto com o ex-marido quanto com o pai de Vinícius, este inclusive frequenta a casa da família e, segundo ela, cumpre com suas obrigações financeiras com relação ao menino. Já Pâmela (39) e Hugo (19) não têm nenhum contato com o pai do jovem, e ela também não costuma comentar sobre o assunto. 


\section{Família 2}

Na Familia 2, a rotina diária não é tão intensa como na Família 1, uma vez que a mãe cumpre seu horário de trabalho na universidade e, salvo os poucos dias na semana em que dá aula durante a noite, tem o tempo livre em casa a partir das17 horas da tarde. Os clientes extras para quem advoga não chegam a fazer de sua rotina intensa, porque estes são esporádicos. A opção pelo curso de inglês, no final do dia, duas vezes na semana, funciona como um hobby, apesar da informante dizer que "não é muito fã do inglês, mas sabe que é importante para as viagens que fazem”. Algumas vezes Edna (52) leva trabalho para casa, mas não vê isso como algo que atrapalhe sua rotina de descanso e lazer. A filha Marina (16) tem apenas uma obrigação: ir à escola pela manhã e durante as tardes estudar e fazer as tarefas. Tanto mãe quanto a filha também fazem atividades físicas na academia, a mãe gosta de musculação e das aulas de dança, já a filha prefere as aulas de Muay Thai com as amigas. O tempo livre da familia é bastante aproveitado. Quando estão juntas durante o final de semana, mãe e filha vão a restaurantes, à praia, ao teatro e ao cinema. Este último é uma de suas atividades de lazer favoritas por causa da atmosfera que envolve o ato de ir ao cinema: "Tu vai ao cinema, tem aquela sala preparada, todo um ambiente para aquilo, o comprar ingresso, entrar na sala, a pipoca. A gente adora a sala VIP” (Edna, 52). Elas também gostam de ficar em casa “atiradas no sofá assistindo Netflix e comendo pipoca” (Marina, 16). Quando a jovem está com o pai, também faz esse tipo de programação, mas aí a mãe aproveita para sair com as amigas em bares, ou para ficar em casa lendo ou assistindo aos filmes que a filha não gosta, como os de investigação e suspense:

Depois que eu já fiz tudo o que tinha que fazer, passeio com as cachorras, às vezes depois de ter saído para algum lugar na noite anterior...daí almoço pouco para poder comer pipoca...organizo o ambiente, preparo o que vou assistir. Eu adoro, uma delícia! (Edna, 52).

Marina (16) também vai ao cinema, ao shopping e a algumas festas com os amigos, a maioria delas em casa, pois Edna (52), dependendo do lugar ainda acha "perigoso" deixar a filha ir a baladas e bares, além do que é menor de idade. Edna (52) também deixa claro para a filha que ela deve tomar cuidado com a exposição perante as bebidas alcoólicas, visto que ela e os amigos costumam beber nas festas que realizam: "Eu deixo claro para ela que, essas tequilas, por exemplo, são álcool ouro, e que o 
organismo dela ainda é muito jovem para ficar exposto assim a este tipo de coisa, tem que ter cuidado”. A menina não se importa de ter que seguir as regras impostas, não só pela mãe, mas também pelo pai, primeiro porque não gosta de discutir, e segundo, porque só argumenta quando é algo que ela realmente acha que vale a pena, do contrário “obedece", afinal: "Ela paga todas as minhas contas, tipo, o que eu vou fazer?" (Marina, 16). Assim, é possível afirmar que mãe e filha têm uma boa relação, baseada em longas conversas e cumplicidade. Edna (52) e o ex- marido têm uma relação de respeito e decidem juntos as questões sobre a educação da filha, mas, diferentemente do que acontece na Família 1, não existe uma convivência.

Quanto às relações familiares da família extensa, elas também afirmam que não há conflitos e que ambas as famílias são unidas (Edna e do ex-marido), mas a de Edna tem mais unicidade, pois o pai de Marina (16) costuma discutir com frequência com sua familia, o que é desaprovado pela filha. Porém, a mãe, a filha e o pai de Marina (16) moram aqui em São Paulo e o resto das duas familias está no Sul, assim, convivem quando dá, seja nas férias ou em datas comemorativas especiais.

No que diz respeito aos relacionamentos amorosos, Edna (52) é discreta e não expõe sobre isso. Mas, após ter uma separação "complicada” do pai de Marina (16), teve apenas um namorado por alguns meses, depois disso, se relacionou com alguns homens, mas nada sério. Ela se diz muito "seletiva" depois da separação e prefere não se envolver com ninguém que vá tirar a liberdade que tem. E, apesar de entender o discurso liberal da filha quanto à sexualidade, é mais reservada e, pode-se dizer que, mais conservadora: "Ah eu aprendo muito com ela, demorei para entender, mas agora não rotulo mais ninguém e estou mente aberta!” (Risos) (Edna, 52). A mãe ainda conta que, quando a filha falou que iria receber a visita de um menino que estava "ficando" e "apaixonada", ela preferiu não se opor, pois sabia que a filha iria ver o menino de qualquer jeito, então preferiu que isso acontecesse em casa, com a presença dela.

Marina (16), então, é uma jovem com o pensamento liberal com relação à sexualidade e aos relacionamentos amorosos, ela nunca namorou e diz que é "racional" no quesito relacionamento, não gosta de "se apegar" porque tem medo de "enjoar da pessoa". Segundo a jovem, ela e os amigos são como "qualquer jovem de hoje em dia": "O negócio é experimentar hoje em dia, não é como antigamente. A gente beija mais de um por festa, se tem vontade e gostamos de pessoas, não importa se é menina ou menino" (Marina, 16). As opções sexuais não são "rotuladas" e ela se diz "à vontade" 
para conversar sobre isso com a mãe em casa. Suas posições sobre questões de gênero são muito definidas em tudo o que fala, e, especialmente, quanto à telenovela nas cenas em que aparecem falas preconceituosas com relação ao gênero. Não por acaso que, como vimos no capítulo anterior, selecionou inúmeras sequências do núcleo da família de Nicolau que tratavam de machismo e homofobia. Marina (16) pontua:

A gente tem mania de estereotipar tudo, tem mania de dar nome para tudo. A nossa sociedade é muito machista, mas isso é em todo o globo. Não acho que seja só no Brasil, o mundo inteiro é muito machista e muito homofóbico.

A familia comentava e refletia, de maneira aprofundada, com mais frequência as cenas de machismo, feminismo e homofobia do que a Família 1. Eram comuns comentários como: "Ah nessa novela a maioria é, como diz a Marina, machista escroto! (Risos). Hetero, branco, etc... Quem não era escroto? O vovô da Luz e o viado que não era macho, o Adamastor" (Edna, 52). Marina (16) acha positivo que tenham colocado uma trans na trama, a Marcos Paulo em que a atriz também é uma trans, porém critica negativamente como são construídas as personagens homossexuais nas telenovelas, pois acha que são colocadas nas histórias só para cumprirem o papel de "politicamente correto" e não como algo natural:

Assim eles enfiam um casal gay e fazem duas pessoas que é meio nada a ver como enredo daí eles são gays. Daí tipo, necessariamente o pai de um vai implicar daí vai ter o preconceito. É meio ensaiadinho sabe? Eu acho que tinha que ser uma coisa mais surpreendente. Tipo bota um protagonista gay. Tá vai ter preconceito? Vai, porque quemé LGBT sofre preconceito, mas assim tinha que ser uma coisa mais natural, original, porque é meio forçadinho (Marina, 16).

Ao falarem sobre as cenas de sexo em $O$ Sétimo Guardião, mãe e filha não se sentem desconfortáveis como os integrantes da Familia 1 e pontuam que elas eram poucas:

Eu acho que nessa novela as cenas de sexo eram dentro de um contexto, do enredo, não tinha nada que dissesse: ah não tem porque aparecer, não tinha nada desnecessário! A não ser aquelas da Marilda com o cara quando o marido ficou brocha, mas eram engraçadas, estavam no contexto. Não era exagerado (Edna, 52). 
Já Marina (16) é bem específica ao pontuar as cenas entre o trisal Laura, Sampaio e Louise, e, sem dúvida alguma, ressaltou a questão porque é algo mais naturalizado para ela e, mesmo que tenha utilizado adjetivos que julgavam a ação, é algo mais próximo do seu cotidiano:

A filha do Olavo que começou beijar Deus e o mundo numa hora, ficou bem louca! Toda liberada! Mas acho que tipo mostrou bem, porque o jovem hoje dia experimenta de tudo não tem problema assim, provar aqui e ali para ver o que gosta. Mas ela tava numa putaria muito louca ali!

Tais cenas estavam entre as poucas em que mãe e filha fazia relação da telenovela com a vida real, pois, nesta familia, diferentemente do que acontece na Família 1, esta prática não é comum. Elas mobilizam outros capitais e sentidos quando falam de seu dia a dia, separando, com mais clareza, o que faz parte apenas do universo ficcional, o que é um marcador de posição de classe social, visto que, na Família 1, o capital cultural advindo da mídia tem papel mais determinante nas apropriações do cotidiano.

\subsection{Espacialidades: a ritualidade na assistência da telenovela}

Mesmo com as novas tecnologias que proporcionam distintas maneiras de assistência da televisão, como pelo telefone celular, computador ou tablet, permitindo com que os espaços dessa assistência sejam ampliados a qualquer lugar, o espaço doméstico continua sendo o principal local de participação e assistência da TV, e de programas como a telenovela:

A situação receptiva das mensagens televisivas é marcada pelo espaço familiar. A TV interpela o espectador enquanto indivíduomembro da comunidade familiar, reunida na parte da casa onde se concentra a atividade coletiva (Sodré, 1984, p.58).

Esta assistência, dotada de um ritual familiar compartilhado, atualmente é ampliada e dotada de outros sentidos e significados, visto que, apesar de ainda ter papel importante dentro dos lares, a televisão divide o espaço com outros meios. A contemporaneidade faz com que as espacialidades sejam divididas e sobrepostas, e cada uma delas têm função importante dentro da dinâmica de usos e apropriações dos meios. 
Além do ritual de assistência da telenovela, levamos em consideração "os espaços de circulação da telenovela" (LOPES, BORELLI e RESENDE, 2002, p. 142) e o consumo de mídia dos receptores na investigação da recepção como um todo.

\section{Família 1:}

Na Familia 1, a principal televisão da casa está no ambiente da cozinha e sala e está num ambiente em que a maioria das dinâmicas do lar acontecem, sendo um lugar frequentado pela maioria dos integrantes. O outro aparelho fica no quarto das irmãs, mas não possui a televisão a cabo. $\mathrm{O}$ espaço mais limitado faz com que a TV, quando ligada, seja a protagonista do ambiente e fica ligada na maior parte do tempo.

Durante a tarde, quando a maioria dos integrantes está trabalhando, Vinícius (12) fica sozinho em casa e assiste ao canal de tv a cabo Warner Channel porque gosta das séries de humor. O History Channel também está entre os favoritos por causa dos realities de competições: "Eu adoro um que é Desafio sob Fogo, porque é uma competição de inventar a própria arma, é um desafio que ganha dinheiro, é americano, da hora" (Vinícius, 12).

Quando Ana (36) e Pâmela (39) chegam em casa, no final do dia, elas trocam o canal da televisão e colocam na Globo. Normalmente é Ana (36) quem chega mais cedo e, quando "dá tempo de chegar" ela gosta de assistir às telenovelas das $18 \mathrm{~h}$, acompanhava Espelho da Vida (Globo, 2018-2019) e também começou a gostar de assistir a recém-estreada Órfãos da Terra (Globo, 2019): “Eu adoro essas das seis porque são românticas!” (Ana, 36). A informante também gosta de Verão 90 (Globo, 2019), não só porque aparecem muitas cenas de dança de lambada e ela já foi dançarina, mas também porque admira o resgate da época feito pela trama e associa ao que viveu nos anos 90: "Os anos 90 acho que foram umas das melhores épocas... até as músicas eram diferentes de hoje. E quando a novela conta né e passa algumas coisas, você relembra né, você revive aquilo!" (Ana, 36). Então, ela fica organizando o que precisa na casa ou então fazendo o jantar (ela e a irmã se dividem de acordo com quem chega mais cedo em casa) e, ao mesmo tempo, assistindo às telenovelas. Quando terminam as tarefas domésticas, senta em frente à TV para assistir o que está passando e para "mexer um pouco no celular". O Sétimo Guardião inicia dentro dessa dinâmica, em que a 
receptora se divide entre as "coisas da casa" e o descanso. O horário de assistir à telenovela é o momento de lazer, de relaxar no sofá.

Quando Pâmela (39) chega, a TV ainda está ligada na telenovela das 21h, e, após tomar seu banho e organizar o que precisa em seu quarto, ela também fica na sala com a irmã para assistir à telenovela e conversar, pois esse é o momento do dia que elas têm para fazer isso. Vinícius (12), no momento da telenovela, circula entre o seu quarto e a sala, algumas vezes ele também senta para assistir à telenovela com a mãe e a tia, mas, na maioria do tempo está no seu quarto, no telefone celular.

Quando termina a telenovela, se não gostam do filme ou do programa seguinte, a familia muda o canal para algum que tenha algum filme "interessante", e, após algumas horas, as irmãs vão dormir, porque precisam acordar cedo no dia seguinte para trabalhar. Algumas vezes, os meninos ficam na sala assistindo a seus programas, mas, no máximo meia noite, devem estar na cama, isso, normalmente é "cobrado" por Ana (36): "Quando tá tarde da noite e escuto o barulho aqui eu levanto, venho aqui e desligo a televisão e mando os 2 para o quarto porque é hora de dormir, porque no quarto deles não tem televisão".

Quanto às refeições, não existe uma regra, em alguns dias elas são feitas em conjunto entre Pâmela (39), Ana (36) e Vinícius (12) e Hugo (19) raramente está porque, nesse horário, está na escola, ele janta com a família aos finais de semana. Em outros dias, cada um faz a refeição no horário que quer, dependendo também de quando chegam em casa. Muitas vezes, Pâmela (39) e Ana (36) jantam juntas antes ou no horário da telenovela, e Vinícius (12), por estar na casa do pai ou no futebol, come quando chega. Nos finais de semana, a família costuma fazer as refeições juntas em casa, quando recebe outros membros da família ou na casa da mãe ou dos irmãos.

Por diversos momentos, durante a assistência de O Sétimo Guardião, todos os membros da família pegavam o celular, especialmente para trocar mensagens no WhatsApp ou verificar o status postado de algum contato ou então checavam o Instagram e o Facebook, estas são as três redes sociais utilizadas pelos informantes. Assim, inúmeras vezes, os comentários sobre a telenovela se misturavam com o que estavam vendo ou fazendo nas redes sociais: "Tá feia essa foto para mim postar? Que eu tô na academia?" (Ana, 36), após nossa resposta de que a foto não estava "feia", ela diz: “Vou postar e colocar a legenda: Morri!” (Ana, 36). 
Com relação ao consumo de mídia da Família 1, eles não costumam ler jornais, nem on-line e também não têm o hábito de ler revistas, com exceção de Ana (36), que esporadicamente diz "olhar" alguma revista no trabalho, como a revista Caras. Para saber das notícias, elas assistem ao Jornal Nacional da Globo ou eventualmente veem as notícias que alguém compartilha no Facebook. A falta de hábito de leitura de jornais e revistas vem da infância, em que, segundo elas, "as notícias eram boca a boca”, além do que, como já comentamos, por diversos anos, elas não tinham eletricidade em casa. Como já mencionado também, a familia têm pouco hábito de leitura de livros de literatura, e, quando leem, as obras preferidas são de autoajuda. As lembranças sobre programas televisivos são da época em que, conforme já explicamos, moravam na cidade, e são dos desenhos animados Pica-Pau, Tom e Jerry e do seriado humorístico Chaves. As irmãs lembram que as primeiras telenovelas que assistiram e de que têm lembranças são: Rainha da Sucata (Globo, 1990), Tieta (Globo, 1989-1990), Pedra sobre Pedra (Globo, 1992), A Viagem (Globo, 1994) e o remake de Irmãos Coragem (Globo, 1995).

Ana (36) escuta emissoras de rádio no carro, a caminho do trabalho e costuma escutar música no Youtube, em seu telefone celular, quando está em casa. Pâmela (39) não escuta rádio, mas também escuta música pelo Youtube. Vinícius (12) também tem o hábito de escutar seus funks, rap e, às vezes, pagode em seu celular através do Youtube.

A família nunca teve computador e o acesso à internet, tanto em casa quanto na rua é feito pelo telefone celular. Devido ao acesso à internet, eles utilizam com maior frequência o WhatsApp. Ana (36) usa bastante a rede social de conversa por causa do trabalho, para agendar e reagendar os horários de suas clientes do salão de beleza. Os integrantes da familia também acessam o Facebook e o Instagram. Porém, Ana (36) ressalta que, fora o WhatsApp, não realiza muitas ações nas redes sociais: "Eu não sou muito fã de internet sabe? Eu sou meio das antigas. O Instagram eu não comento nada, algumas vezes eu curto alguma coisa, no Facebook eu curto mas eu nunca comento nada” (Ana, 36). Ela também diz que sente falta dos contatos mais tradicionais, como ligação telefônica: "Cê não escuta mais a voz do outro pelo telefone, tudo é falado pela internet, WhatsApp, escuta só por áudios. Não tem mais isso de ah vou te ligar... eu sinto falta disso, às vezes”. Já Pâmela (39) conta que suas ações favoritas nas redes sociais é, como já tinha comentado, “ver as coisas dos outro”. Ela costuma ver os resumos das telenovelas nos sites especializados quando já sabe antecipadamente que 
não poderá assistir ou quando perdeu algum capítulo. Ela lê e conta o que leu para a irmã Ana (36). Ambas não gostam quando o resumo antecipado não condiz com que realmente vai ao ar. Outra prática é de que, quando querem assistir a algum capítulo perdido, acessam a plataforma Globoplay, mas assistem apenas os vídeos gratuitos, já que não são assinantes.

As duas irmãs, conforme também já relatamos, utilizam ainda a rede social de relacionamento Tinder. Pâmela (39) contou, dando risada, um dia que esqueceu o celular em casa: "Quando eu lembrei já tava no ponto de ônibus e não ia voltar para buscar...daí pensei : Ah vou fazer essa experiência de ficar sem celular para ver como é, já aproveitei! Menina, meu dia rendeu...você não faz ideia o quanto!” (Risos). Vinícius (12) conversa por diversas horas no WhatsApp e também tem Facebook e Instagram porque, segundo ele, é uma forma que tem quem para "Me comunicar com as pessoas. E as pessoas falam sobre a minha vida e eu falo sobre a vida das pessoas" (Vinícius, 12). O jovem também assiste a vídeos no Youtube, como os de futebol e alguns filmes.

Segue abaixo um exemplo de um dos membros da família assistindo à telenovela. 


\section{Figura 43: Assistência de capítulos da telenovela no telefone celular}

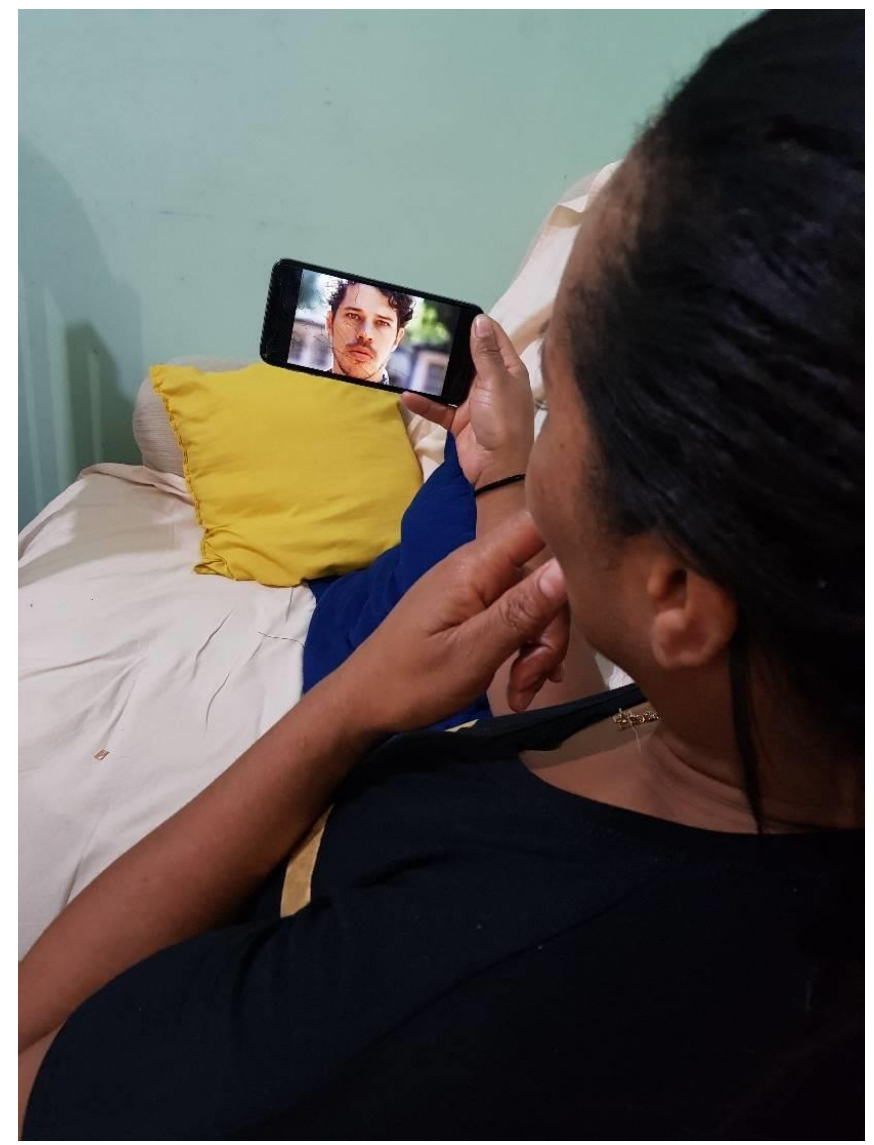

Fonte: Arquivo pessoal da pesquisadora

\section{Família 2}

$\mathrm{Na}$ Familia 2, existem três televisões, uma no quarto de Marina (16) e outra no de Edna (52), mas o aparelho de maior tamanho e que elas utilizam mais é o que fica na sala. Por serem apenas duas moradoras em um apartamento de três quartos, elas possuem maior mobilidade doméstica que a Família 1.

$\mathrm{O}$ aparelho de TV da sala está sempre ligado quando tem alguém em casa, independentemente de estarem ou não assistindo a algum programa. É um hábito que se tornou automático, tanto Edna (52) quanto Marina (16), assim que entram em casa, ligam a luz e a TV: “Ás vezes nem sei por que a TV está ligada!” (Edna, 52). Na família, a TV funciona como uma companhia, muitas vezes ela está no modo mudo quando as informantes estão desempenhando alguma outra atividade, como a leitura de algum livro, ou quando Edna (52) está estudando inglês, por exemplo: “Eu coloco a TV 
no mudo, ou então se a Marina está em casa assistindo algo, eu vou para o quarto...porque daí não tenho essa capacidade mental, o meu cognitivo não alcança!”. Esta prática da família de deixar a televisão sempre ligada é comum e já foi observada anteriormente:

Há lares em que a televisão fica ligada o dia inteiro, às vezes até sem quem ninguém a assista: é um aparelho falando sozinho. As pessoas, em geral, deixam- no ligado apenas para fazer barulho, para dar vida ao lar, para substituir uma companhia ausente com quem se pretendia dialogar. [...] Vendo apresentadores, cenas, entrevistas, elas têm a ilusão de participarem do ambiente (MARCONDES FILHO, 1988, p. 9).

Depois que chega da escola ou de alguma atividade extra, como academia ou encontro com os colegas para fazer algum trabalho, ela estuda e depois assiste na televisão programas de decoração, moda e culinária, seus preferidos. Como a mãe assina todos os canais de filmes da TV a cabo e a Netflix (elas acessam também na TV porque o aparelho é Smart TV), a jovem também gosta de assistir séries como Grey's Anatomy (Canal Sony e Netflix), Vickings (Netflix), Brokling 99 (Netflix), The Society (Netflix) e Game of Thrones (HBO). Ela assiste às telenovelas que estão no ar.

Quando a mãe chega, elas ficam juntas no sofá da sala conversando sobre como foi o dia e assistindo à televisão. Como têm hábitos saudáveis quanto à alimentação, elas preferem jantar cedo, então, enquanto Edna (52) prepara o jantar, que muitas vezes é apenas uma salada (Marina começou a ser vegetariana), elas assistem a $O$ Sétimo Guardião. Inúmeras vezes o jantar acontecia antes mesmo da telenovela iniciar. Tanto a mãe quanto a filha assistem à telenovela com os telefones celulares perto, na guarda do sofá, mas Marina (16) é que acessa o aparelho a todo momento, ele fica mais em sua mão do que no sofá. A maioria das atividades que a jovem faz, ela faz com o celular na mão e costuma também deixar um fone de ouvido em uma das orelhas porque assiste a vídeos no telefone, entre eles os stories do Instagram, e escuta alguns áudios enviados pelos amigos. Edna (52) conta que, por diversas vezes, quando foi acordar a filha pela manhã para ir para escola, encontrou a jovem com o telefone na mão. Marina (16) ri e fala: "Sim, ele tá sempre comigo, na mão, para tudo!". A mãe ainda relata que "cobra" que a filha não fique até tarde no celular, durante a semana, porque tem que acordar cedo no outro dia para ir na aula. 
Edna (52) também assiste às telenovelas que estão no ar e aos canais da TV a cabo que trazem programas de investigação, como Investigação Discovery, no Discovery Channel, e as séries Law and Order (Universal Channel), CSI (TNT) e os programas do AXN. Além do gosto pelos programas, é possível perceber que todos têm relação com o seu trabalho. Além do mais, Edna (52), aponta que "de vez em quando eu até vejo umas coisas assim...um Master Chef da vida”. Ela também gosta de assistir às séries da Netflix pelo alto número de opções disponível: "É legal porque tu põe ali...filmes né... suspense e parece toda a listagem. E depois porque eles vão te dando dicas: Porque você viu isso... Para Edna...tu já te sente... ah eles sabem que eu existo?' (Risos).

Quando assistem a algo juntas, fora as telenovelas, mãe e filha tentam entrar num consenso sobre o que escolher, já que Marina (16) prefere as séries mais direcionadas à idade dela e as comédias românticas, e Edna (52) aquelas que têm a ver com investigação.

No que diz respeito ao consumo de mídia, a Familia 2 não lê jornal, mas assiste às notícias do Jornal Nacional da Globo e da Globo News, além do que procuram ler sites de notícias como Globo.com, Uol e Folha. Marina (16) não tem o hábito de ler revista, mas Edna (52) algumas vezes lê Exame e IstoÉ. Como já mencionamos no capítulo 6, elas têm o hábito de ler livros de literatura diariamente. O hábito de leitura para ambas é advindo da infância, tanto Edna (52) quanto Marina (16) foram estimuladas desde cedo a ler e, por isso, hoje a leitura faz parte da sua rotina, sendo uma atividade prazerosa. O gosto pela leitura é relacionado a um habitus também relacionado à classe social, pois a leitura funciona como uma forma de acúmulo de capital cultural.

Sobre as lembranças com relação a hábitos de consumo midiático, Edna (52) recorda que, em sua casa, a família sempre assistia, juntos, ao Jornal Nacional e ao Fantástico. Ela comenta que, até hoje, lembra das vinhetas de abertura. Comenta ainda que a família assistiu à Copa de 1970 pela televisão de casa, o pai gosta muito de futebol, até hoje. E que, em 1974, compraram a televisão em cores que era "uma novidade" e que alguns vizinhos, que ainda não tinham o aparelho, iam assistir na casa da família. A mãe de Edna (52) costumava assistir à série americana Kojak (Globo, 1973) e ela e irmã a acompanhavam na assistência. Quanto às telenovelas, conta que não tem muita recordação da família assistindo, mas aponta Gabriela (Globo, 1975), 
porque lembra que ela gostaria de assistir, mas os pais não autorizavam "porque não era novela para criança" e passava tarde: "Eu dizia para minha mãe que eu queria assistir só por causa da música, daí sabe o que ela fez? Comprou um LP para eu ficar ouvindo a música!” (Risos) (Edna, 52).

Já Marina (16) fala que assistia muito a desenho animado da Disney na TV quando era pequena, e cita também títulos como Barney (Discovery Kids e Globo) e Os Backyardigans (Discovery Kids). Ela diz que, como sempre tiveram cozinha americana em casa, em que a cozinha é no mesmo ambiente que a sala, mesmo quando os pais eram casados, lembra dela brincando na sala e os pais na cozinha com a televisão no Jornal Nacional. Na hora da telenovela, os pais "controlavam", se houvesse cenas de sexo ou violência, mudavam o canal para que ela não assistisse. Edna (52) confirma a lembrança da filha. Suas telenovelas favoritas foram assistidas com a mãe e são Império (Globo, 2014-2015), Amor à Vida (Globo, 2013-2014). Edna (52) acrescenta que gostava bastante de O Cravo e a Rosa (Globo, 2000), Orgulho e Paixão (Globo, 2018) e Espelho da Vida (Globo, 2018-2019). Marina (16) revela que também que gostava de uma temporada da soap opera Malhação, a com o título Casa Cheia (Globo, 2013).

Elas escutam emissoras de rádio musicais toda a vez que estão dentro do carro e Marina (16) tem acesso ao aplicativo de música Spotify, ela utiliza o plano pago e por isso pode escutar qualquer música "onde e a hora que quiser". A jovem diz que "a música faz parte da minha vida" e dá preferência aos gêneros pop rock nacional e internacional e reggae.

Elas possuem um notebook e um tablet, que é Marina (16) que o utiliza com maior frequência. $\mathrm{O}$ primeiro computador da família era de mesa e foi comprado nos anos 1990, quando Edna (52) estava fazendo sua dissertação de Mestrado: “Eu lembro que fiz curso de informática, era curso de DOS (Risos) com a tela preta e a letrinha verde!" (Edna, 52). Ela ainda fala que, na verdade, seu "primeiro equipamento eletrônico" foi uma máquina de datilografar eletrônica da marca Olivetti, que ganhou dos pais quando terminou a graduação em Direito, e diz, rindo, que o objeto, "era o máximo para a época". Marina (16) têm lembrança de jogar no computador: "Tinha uma fazendinha que eu fiz o pai baixar para mim", além de pintar no programa Paint. Ela diz que o pai desenhava algo e ela pintava o desenho.

Hoje em dia, apesar de terem o tablet e o notebook, elas acessam a internet, majoritariamente, em seus telefones celulares. Edna (52) lê notícias e conversa pelo 
WhatsApp, ela tem as redes sociais Facebook e Instagram, esse último, segundo ela, fez depois de muita insistência das amigas, mas não costuma interagir muito nessas duas redes. E ela fala aos risos: "Tenho só esses três e já é difícil gerenciar!" (Edna, 52). Marina (16) têm Twitter, Instagram e WhatsApp e fala que não tem Facebook porque "na minha idade ninguém usa mais". Diferente da mãe, ela acessa as três redes sociais com grande frequência, pois, como já falamos, está com o celular na mão, na maior parte do tempo. E justifica: "Porque tu tá sempre em contato com as pessoas. Porque tipo assim...eu tenho no Instagram o que eu gosto porque eu não sigo o que eu não gosto. Então, as coisas da minha preferência estão aqui"(Marina, 16). A jovem também vê vídeos de beleza, maquiagem e estilo de vida e comportamento de blogueiras no Youtube.

Segue abaixo, um exemplo, de um dos membros da familia assistindo à telenovela. 


\section{Figura 44: Assistência da telenovela na televisão}

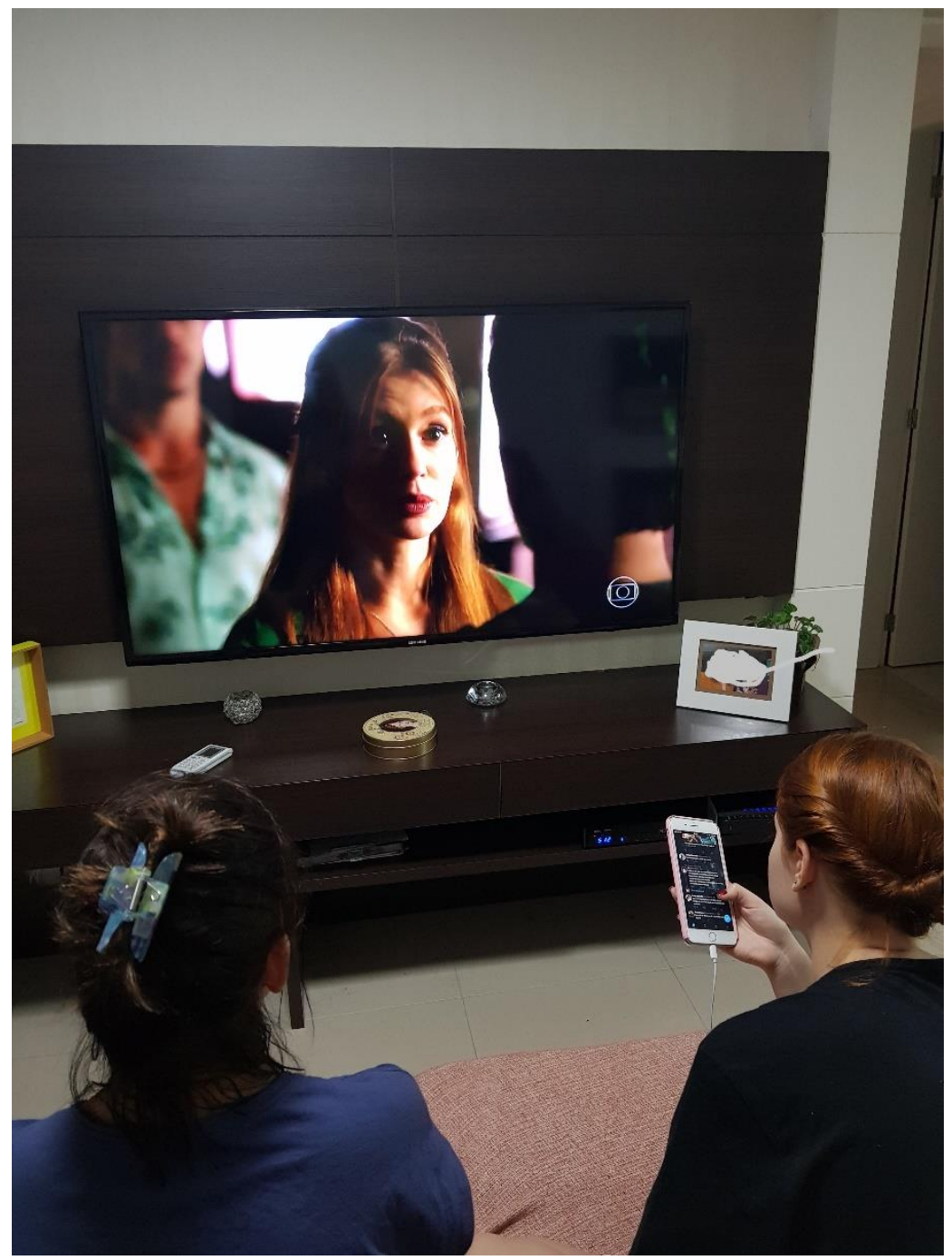

Fonte: Arquivo pessoal da pesquisadora

\subsection{Sensorialidades: as identidades e cidadanias e os receptores de telenovela}

O espaço doméstico tem relação direta com as sensorialidades mobilizadas e vividas pelos receptores, pois o lar é também um ambiente simbólico que fornece e contribui para a formação identitária dos sujeitos (SILVERSTONE, 1994). A identidade é tudo o que dá sentido à vida de alguém e é o conjunto de valores, crenças e visões de mundo. Por isso, é importante ressaltar que, no ecossistema comunicacional contemporâneo, em que o arcaico está o tempo todo confrontado e ocupando o mesmo lugar que o atual e o novo, o tempo, o espaço e as sensações acabam por dar sentido e contribuir para as interpretações não só sobre o que é assistido ou visto na mídia, mas também sobre a visão que as pessoas têm do mundo. Os limites acabam por se borrar, e 
o fluxo de ideias, sentimentos, informações, conteúdos, mensagens é intenso e contínuo.

\section{Família 1}

A Familia 1 se reconhece enquanto trabalhadores que, por ter origem pobre, precisa "batalhar" diariamente para conquistar o que têm, nem que isso signifique se sacrificar durante horas de trabalho em atividades que exigem esforço físico ou abrir mão do lazer e do convívio familiar. E, como já mencionamos anteriormente, isto é motivo de orgulho entre os integrantes e tem um valor simbólico importante. A consciência e o pertencimento de classe dos integrantes ficam claros em diversos momentos, como por exemplo, quando estão contando algo que acontece no dia a dia. Importante ressaltar que Ana (36) e Pâmela (39) são pessoas extrovertidas que não têm dificuldade de expor os fatos que compõem o seu cotidiano e nem o passado. Assim, inúmeras vezes, sua visão sobre a posição que ocupam no espaço social ficava clara também com palavras ditas por elas, como por exemplo, quando Pâmela (39) conta de uma amiga que, sem motivo, está sempre “amarga" e "reclamando da vida":

Ela tem tudo, uma família boa, mora numa casa linda, não tem que pagar aluguel. Eu falo assim: Imagina se você tivesse que levantar a hora que eu levanto, chegar em casa na hora que eu chego. Eu tenho aluguel para mim pagar, várias conta para mim pagar, e não reclamo nada, dou graças a Deus. Cada dia que eu ponho meu pés no chão, que eu tô andando, vejo que tá tudo bem...que tô com saúde... eu só tenho a agradecer! E mesmo quando eu levanto e não tô disposta...eu tô viva, aquilo ali vai passar.

O jogo de distinção de classe está presente em diversos momentos da vida da família, em casa, quando os integrantes querem se distinguir das outras frações de classe popular mais baixa que a deles, como já exemplificamos anteriormente com relação aos lugares frequentados, ou então quando Vinícius (12) fez questão de mostrar, mesmo que de modo fora do contexto com a conversa, a jaqueta nova "de marca" que a mãe tinha comprado para ele no shopping e que tinha custado "mais que 100 reais". O jogo de distinção também acontece quando os informantes sofrem a violência simbólica por pertencerem à classe popular, no trabalho, por exemplo: 
No início do meu trabalho era assim...tudo o que eu fazia ela tinha que reclamar, tinha tipo uma implicância... e gritava, e eu odeio quandofalam alto comigo. Eu não sou surda. Ou então passava por mim e dava aquela tombada. Teve um dia que ela me tirou do sério. Foi a primeira e a última vez né que ela foi muito grossa comigo e ela tava com um problema lá [...] Daí eu falei: Chega! Olha aqui eu nunca desrespeitei ninguém aqui, sempre trabalhei com respeito pra ter o respeito que eu mereço, e você não tá me respeitando...se você não tá gostando do meu trabalho, você pode me dispensar. Sem problema nenhum, você não é obrigada a gostar de mim e do meu trabalho. Só que eu tô fazendo do jeito que você pede, mas para você nada tá bom! Se vocêficar me ofendendo eu vou pegar minha bolsa e vou embora. (Pâmela, 39)

Pelo fato de gostarem de falar, as conversas na casa da familia, na maioria das vezes, acontecem em um tom mais alto, e as irmãs, quando estão contando algo, têm o costume de falar ao mesmo tempo. E elas mesmo brincam com a situação: "Olha não precisa se apavorar...casa de pobre e de baiano é assim mesmo!’

Os momentos de interação entre a familia e a televisão articulam diversos sentidos, entre eles os que dizem respeito à identidade de classe, às subjetividades de cada informante, às sensações e aos sentimentos que flutuam entre o que é vida real e o que é telenovela. Na família, como já afirmamos, essa relação diacrônica de articular a própria vida e a telenovela é feita com constância. Exemplo se verifica quando Ana (36) faz relação entre o final de uma telenovela e a vida real, ela não gosta quando o "mocinho" sofre muito:

A pessoa é boa e sofre muito, o sofrimento não acaba e a pessoa má só se dá bem. E só no finalzinho que dá certo...pô não pode dar certo antes não? Se faz tudo certo e a vida só te dá pancada, daí só no final que pessoa vai ser feliz, daí vai ver muito pouco o que bom, a felicidade mesmo. Porque o mau fica muito tempo ali fazendo a maldade. Acho isso errado. Isso a novela é diferente da vida um pouco. Porque na vida, muitas vezes o mau se dá beme o bom não se dá. Na novela o bom sempre se dá bem, mesmo que seja no final.

Ana (36) diz que a telenovela mostra inúmeras situações que ela gostaria de viver, principalmente aquelas relacionadas a bens materiais: "Sempre tem alguma coisa que eu queria ter, um carro bom, um casa ou um apartamento bem lindo, bem decorado. Bem chique”. Já a irmã costuma fazer associações entre a sua personalidade e 
a das personagens de $O$ Sétimo Guardião, quando diz que se identifica muito com a Luz porque, assim como a moça, também "gosta de ajudar todo mundo", mas que não se considera tão "boazinha" quanto a protagonista. E, rindo, lembra o fato de que Ana (36) fala que ela parece mais é com a Mirtes. Pâmela (39) ainda acrescenta que tem identificação com Afrodite, porque: "Mesmo ela tendo um marido que é um traste né, ela era dedicada, cuidava da casa e dos filhos. Então eu acho que ela era uma dona de casa exemplar, mãe de família”.

Entretanto a família pensa que O Sétimo Guardião dá maus exemplos para as pessoas que assistem, através de personagens como Olavo, "o cara faz todas as vontades da filha, se submeter a crimes por causa da filha, ele tá fazendo tudo isso por capricho dela. Depois ela vai se ferrar né, vai se dar mal e ele vai ser o culpado" (Ana, 36). Citam também o comportamento corrupto do prefeito Eurico, apesar de saberem que "isto existe bastante no Brasil”.

A família atenta bastante para as questões de trabalho na telenovela e faz essa relação possivelmente pelo espaço e o tempo que o trabalho ocupa em suas vidas. Ana (36) diz que nunca viu "muita gente trabalhando nessa novela” Ela pontua apenas o trabalho da dona do salão de beleza Neide e da sua mãe no restaurante, duas funções associadas à classe popular, e adiciona:

A Luz era professora e nunca dava aula, o Gabriel vivia de ar eu acho... aquele Olavo, era ela rico e empresário, mas não passa ele indo cuidar das coisas dele, dos outros bens, não passa ele indo na empresa trabalhar. Como assim? O cara tem um monte de dinheiro e fica afastado da empresa dele? Fica só em Serro Azul.

Pâmela (39) não usa estas palavras, mas critica a caracterização das personagens ricas, ela afirma que a falha é comum em também em outras tramas:

E na novela é assim: se a pessoa tem dinheiro e é rica ela anda sempre no salto e maquiada, mesmo dentro de casa. Então, eu acho que não é assim, que tem mostrar a pessoa sem maquiagem, toda escabelada. Todo mundofica descabelada em casa, jogada no sofá, de pijama, não passa elas de pijama. Acho que eles separam demais.

Vinícius (12) gosta de ver na televisão em geral, não só na telenovela, os carros de luxo, pois seu "sonho é ter um" e, quando as personagens da telenovela 
mencionavam alguma viagem, ele "sempre ficava imaginando" estar no lugar: " $O$ prefeito e a mulher dele sempre falavam de Dubai, eu quero ir lá um dia, morar eu acho...lugar da hora, cheio de diversão e rico!” (Vinícius, 12). As cenas em que o prefeito Eurico falava de corrupção também eram motivo de crítica por parte do jovem, pois ele afirma que "esse só faz coisa errada". Outro ponto relacionado à cidadania e identidade de raça, por mais que não aprofundado pelo jovem, manifesta-se quando cita que a telenovela anterior, Segundo Sol (Globo, 2018) "vacilou muito" porque "Era para ter mais negros, mas dificilmente teve negros, teve mais branco sendo que é em Salvador" (Vinícius).

\section{Família 2}

A Familia 2 também reconhece a importância do trabalho como forma constituidora do cotidiano e do seu modo de vida, apesar de, diferentemente da Família 1 , ter sua origem em uma família bem estruturada e com posses, o que possibilitou o acúmulo de capitais maior que na Família 1. O fato da família extensa materna também ser composta por professores universitários é motivo de prestígio e valorizado tanto pela mãe quanto pela filha: "Tipo o vô compra e vende imóveis, mas não tem essa cabeça para negócios, de empresário porque a gente é uma família de professores, todo mundo intelectual...a gente é muito de outro nivel!” (Risos) (Marina, 16). Edna (52) costuma repetir que o exemplo dos pais quanto ao trabalho e ao fato de estudar para "ser alguém na vida" sempre foram muito fortes e presentes no dia a dia de sua família. Marina (16), além do exemplo dos avós, reconhece na mãe a mesma lição: “Tipo assim...não que eu seja arrodeada de dinheiro mais eu vejo que a minha mãe...ela trabalha, ela tem o dinheiro dela e ela é independente. Eu vejo isso no meu dia a dia é é um super exemplo".

Importante ressaltar que, apesar de jovem, Marina (16) tem um capital cultural acumulado e gosto por discutir assuntos da atualidade como os relacionados às questões de gênero e à política. Ela diz gostar muito das aulas de filosofia da escola e de quando debatem assuntos polêmicos, uma vez por mês participa de uma atividade extra na escola direcionada apenas para debates de atualidades. E lamenta que na escola não tenha Grêmio Estudantil ou outra forma de incentivar as atividades políticas. Inclusive, ela e mãe declaram com frequência que não são a favor das ideias do Presidente da República, Jair Bolsonaro. 
Ao contrário da Família 1, esta família não articula a própria vida com a vida mostrada na telenovela. As articulações acontecem num âmbito maior e são colocadas num contexto de sociedade. Como, por exemplo, quando observam o comportamento machista e preconceituoso de Nicolau:

Machismo, homofobia, a gente convive, tá ligado? O tempo inteiro, é fala machista em todo lugar, não só na TV. É tão normal, porque tá tão dentro da gente que às vezes sai umas coisa meio merda, que daí quando tu para pra pensar, tu fala: Mas pera! O que eu acabei de falar ou ouvir. Tá bastante internalizado (Marina, 16).

A familia não se identifica com as personagens e nem com situações mostradas na trama, salvo a exceção de Edna (52), que ri ao falar da caracterização de Valentina: “Adoraria aquelas roupas maravilhosas da Valentina! Só isso que eu me identifico! Aqueles sapatos maravilhosos, as joias, o que são aqueles os colares cravejados de diamantes!’. A informante além de gostar, anda bem vestida por causa de seu trabalho. Ela é bastante ligada ao consumo de roupas, sapatos e bolsas e tem o estilo sóbrio. O seu gosto para se vestir e o preconceito de classe social ficam claros nesse comentário:

Quando eu passo na frente de uma loja popular, eu sempre me pergunto: a saia com tecido mais ou menos, tecido assim barato, vai ser a mesma saia se for liso ou se for comflor que não combinam uma com a outra, não? O que eles fazem? Eles botam na vitrine as que não combinam uma com a outra. Impressionante isso! Não entendo por que, o preço é o mesmo, por que? Porque eles usam a saia que tem uma flor com a blusa que tem outra flor, se é o mesmo preço tu comprar uma lisa! Eu não consigo entender isso! Para mim isso é o estereótipo do pobre! Riso. E assim, tu nunca vai ver um estampado miúdo, delicado...é sempre pá! E a visão do inferno algumas coisas! (Risos) (Edna, 52).

Porém, na maior parte do tempo, os comentários são de que não é a telenovela a responsável por despertar sentimento de identificação ou representatividade e sim o contexto social do qual fazem parte:

Eu vejo muito mais com exemplo de mulher que quero ser e que me identifico em casa né. Exemplo de casa, escola. Tá a TV influencia, com toda a certeza, porque tu tá sempre olhando. Quer dizer, hoje em dia, internet mais do que TV, mas do mesmo jeito...TV sempre influencia e sempre vai influenciar. Porque tipo assim, eu tenho uma professora, que ela é muito empoderada, ela dá aula, ela é separada, tem o filho dela, é de boa com a vida... ela namora outro professor 
meu e ela tipo assim...ela é muito foda! Daí eu penso: puta mulher foda, quero ser! A minha mãe também, puta mulher foda! Então eu acho que tu vê muito mais por exemplo no teu dia a dia do que na novela.

A associação da telenovela com a classe popular também é feita pelas informantes, como é possível analisar quando Marina (16) compara o papel que a telenovela tem de "influenciar" sua vida e na vida de um jovem que nem ela, mas de classe popular:

Tem muita gente de classe mais baixa que a mãe é dona de casa e não convive com os exemplos que eu tenho, então eu acredito que eu tenho muito mais exemplos do que essa pessoa vai ter. Eu não posso afirmar, afirma que para eles a TV dá mais exemplos porque eu não sou né de uma classe mais baixa, mas eu acredito que sim!

Para a familia, as telenovelas, no geral, mostram 'Um dramalhão, sempre tem a família rica e a família pobre, daí sempre tem conflito de classes, toda a vida assim" (Marina, 16). Porém, concluem que, em $O$ Sétimo Guardião, isto não ficou tão explícito e, mais uma vez, criticam a trama: "O mendigo dessa novela ele tinha tudo, nem o mendigo era mendigo de verdade! Porque quando ele ajudou a Valentina, ele tinha tudo" (Edna, 52).

\subsection{Tecnicidades: narrativas, redes e o gênero ficcional}

Assistir à telenovela é uma competência construída no cotidiano, mas a essa foram acrescentadas pelas novas tecnologias também novas formas não só de assistir, mas de uso e apropriação deste produto cultural. Além disso, a atenção dos receptores se tornou fragmentada e disputada, mesmo que muitas vezes compartilhada, por outros meios. As competências de recepção e consumo foram se adaptando a esse novo ecossistema e variam, por exemplo, de acordo com inúmeros fatores relacionados à classe social, identidade de gênero e geração. 


\section{Família 1}

A recepção da telenovela pelos informantes da Familia 1, de acordo com o que já afirmamos, acontece simultaneamente ao uso do telefone celular. É Vinícius (12) quem mais acessa o aparelho durante a telenovela entre os outros integrantes da família. Porém, ele vai ao celular para conversar no WhatsApp ou para checar alguma postagem, principalmente de fotos no status do aplicativo ou no Instagram, mas, nesse último, ele apenas olha as atividades das pessoas e não publica nada. $O$ jovem não curte, compartilha ou comenta nada sobre a telenovela com seus contatos. A maioria das suas atividades no Facebook é postar foto sobre os torneios ou treinos de futebol de que participa, ou então compartilhar posts de futebol. A mãe não comenta nada sobre a telenovela nem no Facebook e nem no Instagram, elas apenas olha e raramente curte. Ela até gosta de ver os posts sobre a telenovela, especialmente quando falam sobre algo que vai acontecer, mas não realiza nenhuma ação a respeito desses posts. Ela não costuma curtir, comentar ou compartilhar assuntos que geram polêmica, como política, por exemplo. E o que posta são assuntos de utilidade pública quando alguém ou algum animal desaparece, frases de autoajuda, curtir e comentar os posts do filho e posta fotos dela e atualiza com frequência as fotos do perfil. Ela afirma não ter tempo, e quando tem prefere responder às coisas "urgentes" em seu WhatsApp sobre trabalho ou conversas com amigos e "paqueras". Em outro momento, já falamos que a informante relata não gostar muito de internet, mas afirma que "se a gente não aprende a lidar com a tecnologia fica pra trás, né” (Ana, 36). Pâmela (39) tem o mesmo comportamento que a irmã, e apesar de usar as redes sociais e também checá-las quando está assistindo à telenovela, o faz menos que a irmã e o sobrinho, e não costuma compartilhar, curtir e comentar assuntos relacionados à trama. Suas atividades no Facebook e no Instagram são curtir e compartilhar vídeos de humor, e posts que falem de política, principalmente os que fazem piada com alguma situação política, curtir e comentar os posts do sobrinho e costuma postar fotos dela. 
Figura 45: Exemplo de atividades nas redes sociais - Ana
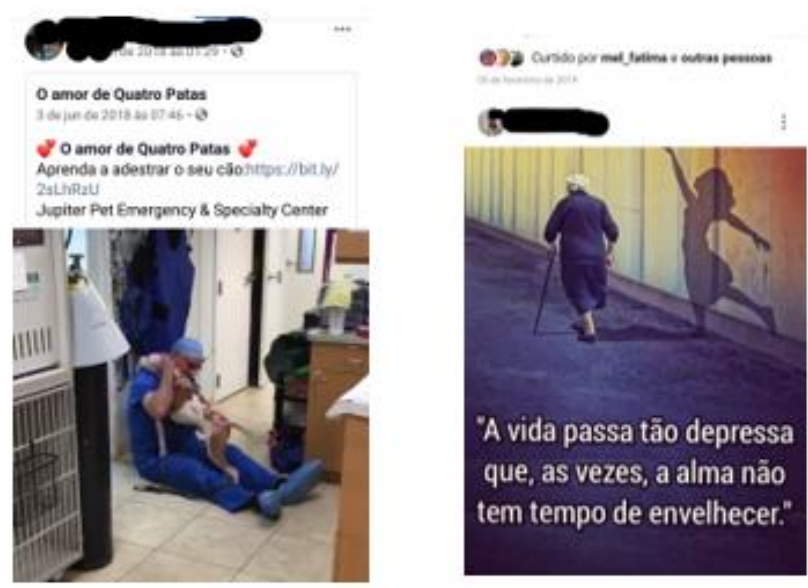

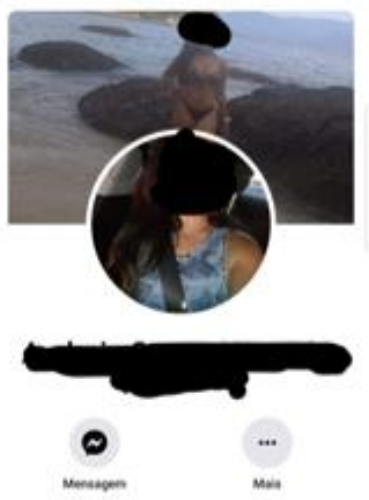

A. Mora en Săo Paulo

Fonte: Redes Sociais da informante

Figura 46: Exemplo de atividades nas redes sociais - Pâmela
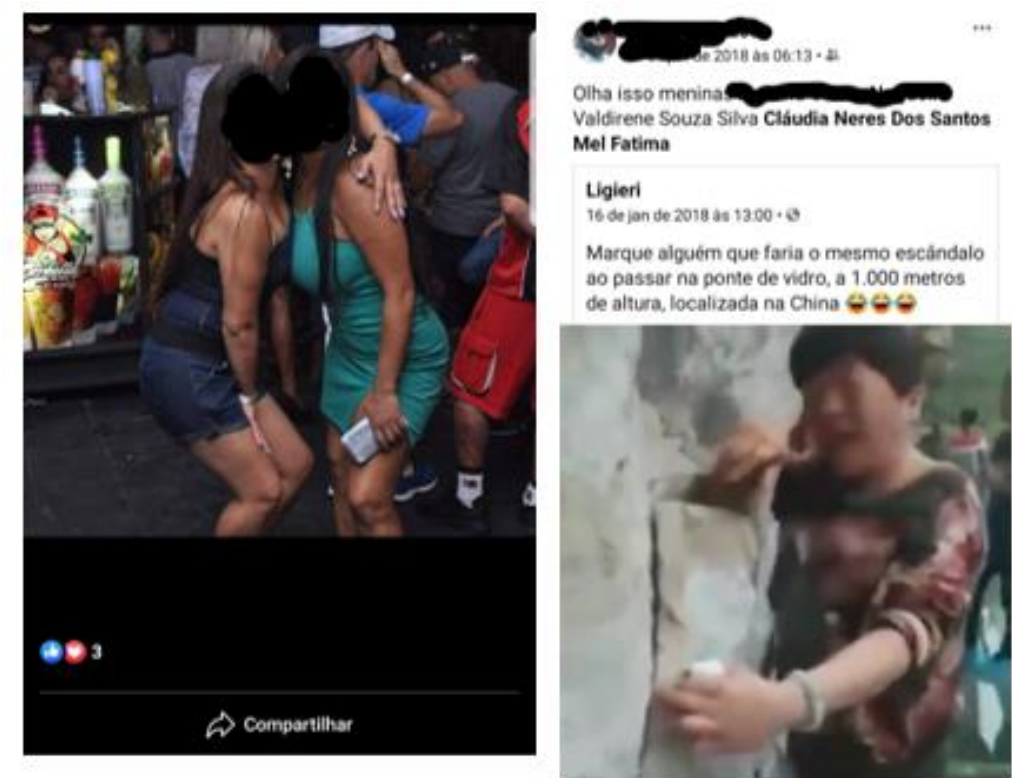

Fonte: Redes Sociais da informante 


\section{Figura 47: Exemplo de atividades nas redes sociais - Vinícius}
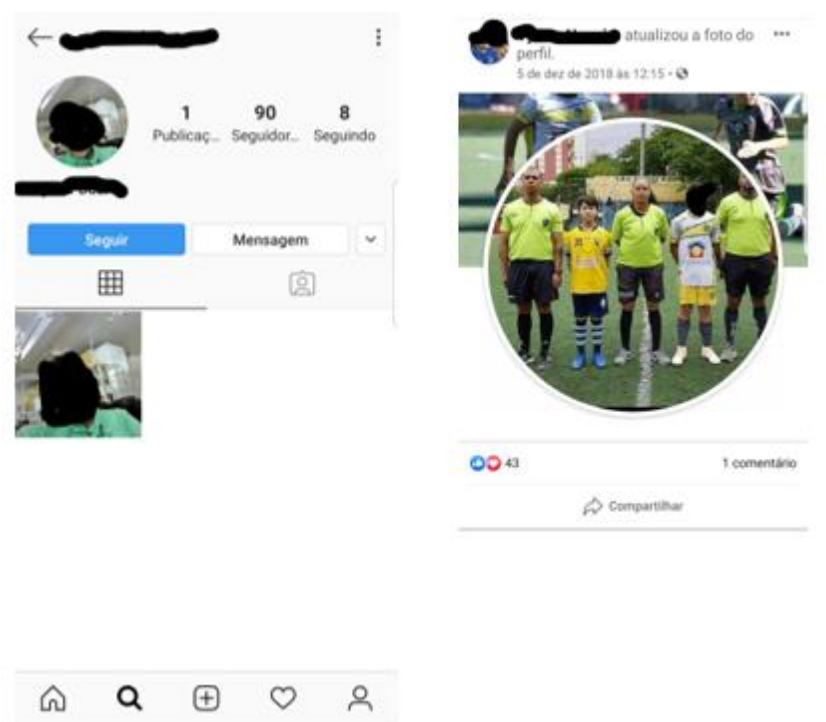

Fonte: Redes Sociais do informante

Assim, é possível constatar que todos os membros da Família 1, apesar da assistência da telenovela ter sido reconfigurada em tempos de transmídia e convergência, eles são receptores, dentro da pirâmide de tipologia de fãs (LOPES e MUNGIOLI, 2011), são espectadores porque apenas assistem, leem e ouvem o que está na internet sobre as tramas. E mais, podemos dizer ainda que, em inúmeras vezes, nem se enquadram dentro da pirâmide, sendo apenas receptores que assistem à telenovela de uma maneira diferente devido ao novo ambiente comunicacional.

No tocante às questões que envolvem a telenovela como narrativa ficcional de $O$ Sétimo Guardião e tudo o que engloba a trama, trazemos um retrato dos documentos codificados no software Maxqda Analytics Pro 2018 dentro do conjunto tecnicidades, para demonstrar todas as categorias que apareceram durante as falas dos receptores acerca da telenovela. É importante destacar que cada categoria tem uma cor e quanto mais vezes foram mencionadas questões que dizem respeito a ela, mais dessa mesma cor aparece no retrato. Então: 
Figura 48: Retrato do documento sobre a telenovela - Ana

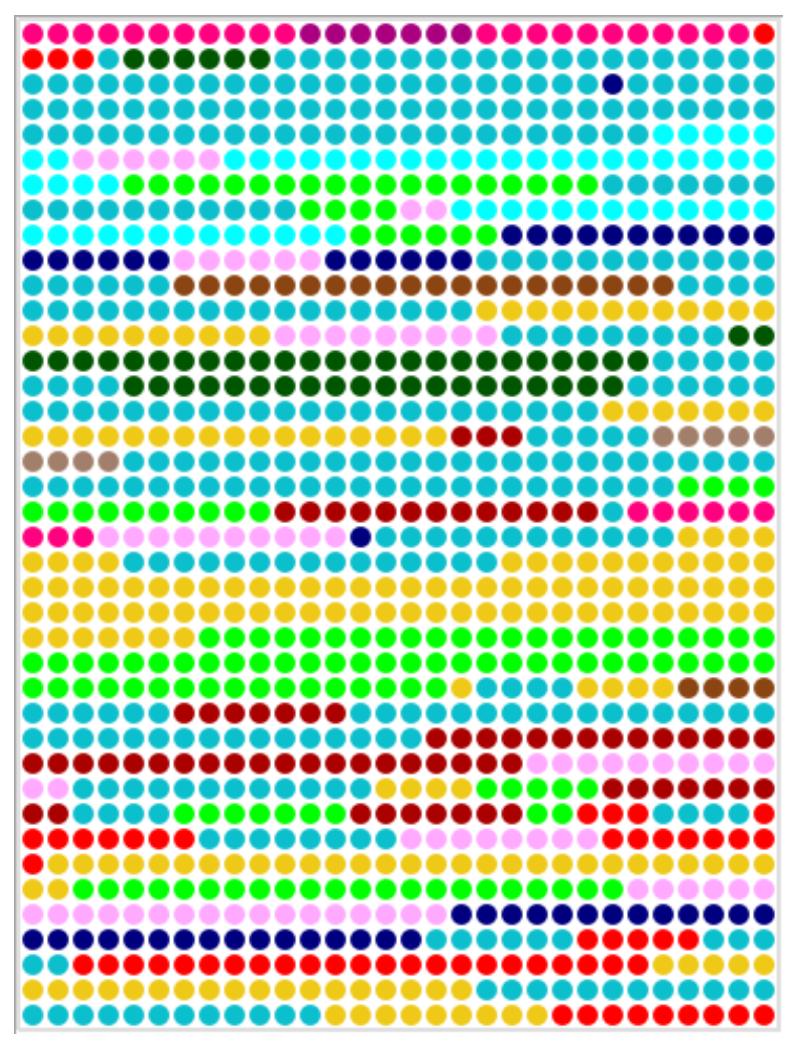

Fonte: Elaborado pela autora no Maxqda 
Figura 49: Retrato do documento sobre a telenovela - Pâmela

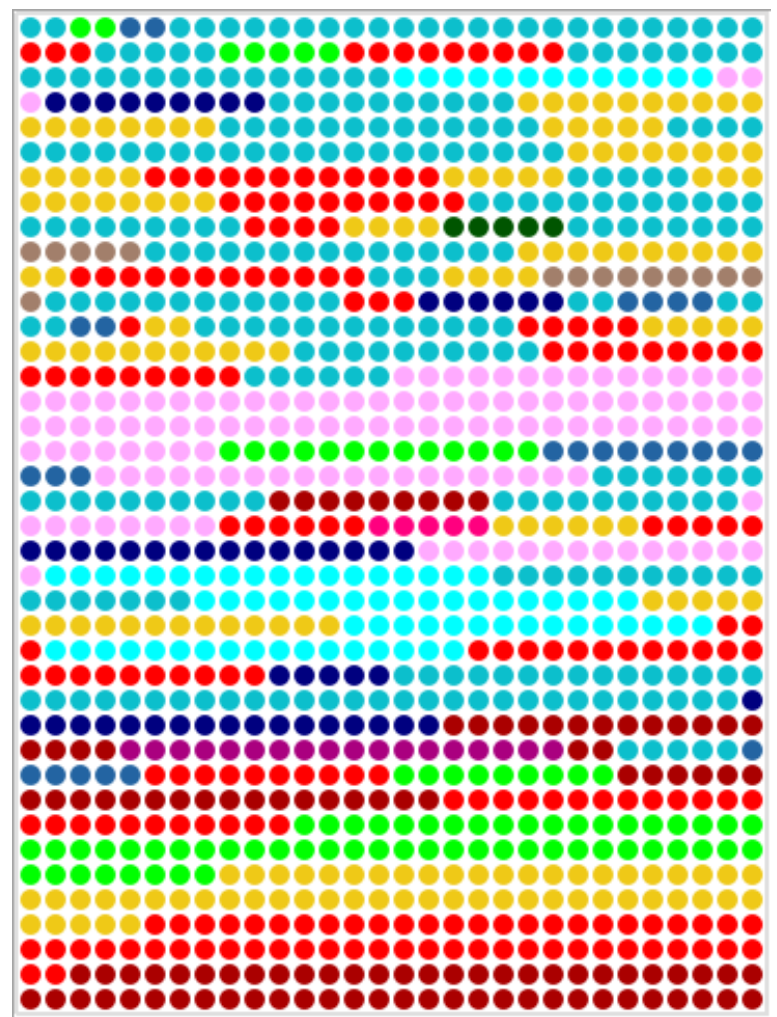

Fonte: Elaborado pela autora no Maxqda

Figura 50: Retrato do documento sobre a telenovela - Vinícius

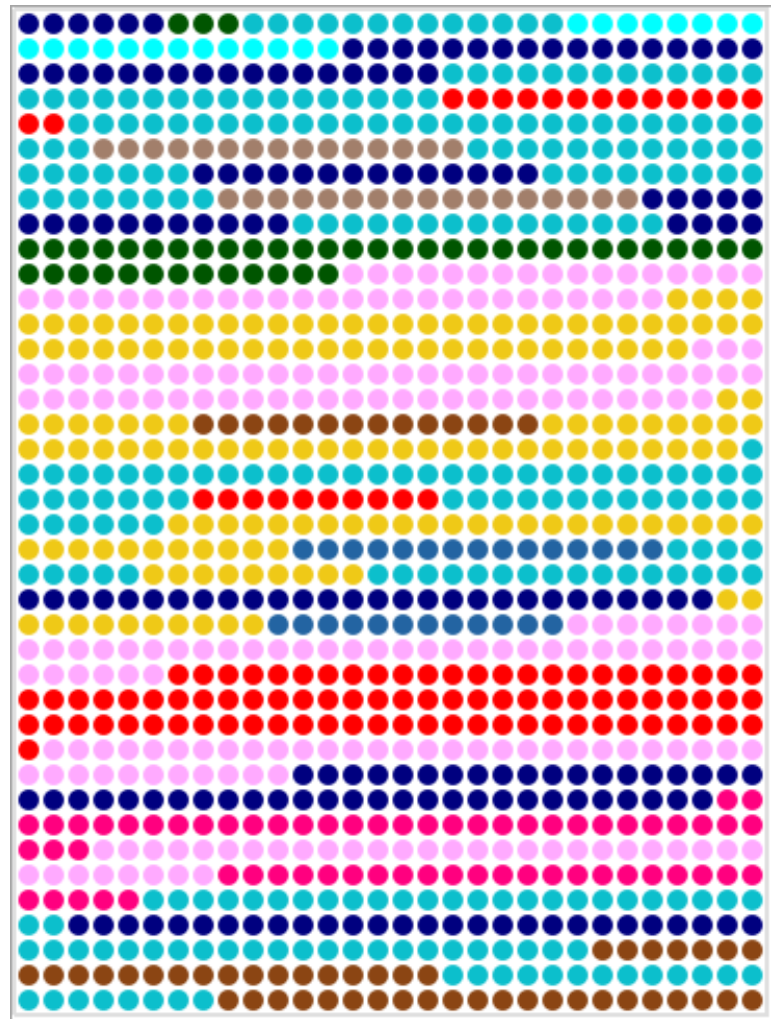

Fonte: Elaborado pela autora no Maxqda 


\section{Legenda dos códigos}

\begin{tabular}{cl}
\hline Cor & Código \\
\hline & Twitter \\
\hline$\bullet$ & Distinção \\
\hline$\bullet$ & Infância \\
\hline & Geracional \\
\hline$\bullet$ & WhatsApp \\
\hline$\bullet$ & Técnica \\
\hline & Facebook \\
\hline$\bullet$ & Emoções \\
\hline & Instagram \\
\hline$\bullet$ & Pertencimento de \\
& classe \\
\hline$\bullet$ & Emprego \\
\hline$\bullet$ & Relações \\
& interpessoais \\
\hline$\bullet$ & Relações amorosas \\
\hline$\bullet$ & Cotidiano familiar \\
\hline$\bullet$ & Cidadania \\
\hline$\bullet$ & Refeiç̃̃es \\
\hline & Assistência \\
\hline$\bullet$ & Econômico \\
\hline$\bullet$ & Relação com a \\
& Telenovela \\
\hline$\bullet$ & Religião \\
\hline$\bullet$ & Geração \\
\hline$\bullet$ & Consumo de mídia \\
\hline$\bullet$ & Roteiro e Texto \\
\hline$\bullet$ & Lazer \\
\hline$\bullet$ & Relações de Gênero \\
\hline$\bullet$ & Política \\
\hline$\bullet$ & Educação \\
\hline$\bullet$ & Relações familiares \\
\hline$\bullet$ & Trabalho \\
\hline$\bullet$ & Sexualidade \\
\hline & \\
\hline
\end{tabular}

Assim, é possível observar que, apesar de haver diferenças entre os retratos dos membros da família, nos três documentos, há grande incidência da cor azul clara, que representa o código Roteiro e Texto, nele estão abarcados também as questões de atuação do ator e construção da personagem. O código aparece com maior destaque porque a familia discute muito a trama de O Sétimo Guardião, e o primeiro ponto que deixam muito claro é que não gostaram da telenovela, endossando com os baixos números de audiência registrados pela trama, conforme já mencionamos. A alta 
expectativa provocada antes da estreia e nos primeiros capítulos se transformou em frustração para os informantes:

No começo passava nossa o mistério...tudo intrigava a gente. Agora já não mais, tá meio chato porque não dá nenhum indício, nenhuma pista porque que tem aquela fonte, de onde veio.. Porque ela não pode ser tocada, porque ninguém pode utilizar a fonte já que é uma fonte de água já que tem que ser guardada. Eu não entendo! (Ana, 36).

Pâmela (39) acrescenta que o principal do enredo era o mistério sobre a fonte, e que, depois que foi revelado, conforme ela, "cedo demais", a estória não fez mais sentido. A família, mesmo não gostando da história da telenovela, se dizia "curiosa" para saber quem era o assassino dos guardiões, pois, como já mostramos, eram estas as cenas escolhidas como as melhores. Mas, fazem uma leitura crítica acerca de uma possível estratégia da emissora quanto à trama: "Todas novela da Globo eu acho que quando ela não tá dando audiência eles matam, começam a matar os personagem. Começa a aparecer aquele negócio de suspense sabe?” (Ana, 36).

Ainda sobre o roteiro e o texto da telenovela, os informantes relatam que ela é uma mistura de drama com ação, suspense e comédia. E o tempo inteiro relacionam a trama com a realidade, como nas cenas em que Nicolau aparece tendo algum comportamento machista: "Ele é tão machista que mesmo tendo transado com a própria mulher, não lembra. Inseguro. São os homens de hoje em dia mesmo” (Ana, 36). Estas cenas não foram escolhidas como as preferidas da familia quando a telenovela foi reeditada, mas as duas irmãs comentam, criticamente, sobre a questão: "Ela mostra algumas que é real que é a parte do pai lá do machismo, das pessoas que é egoísta que só pensa me dinheiro, que o dinheiro consegue fazer ele mudar, porém ele é machista” (Pâmela, 39). A corrupção do prefeito Eurico, mais uma vez, é pontuada como algo que faz parte "da realidade".

Os informantes, embora afirmem que a telenovela "decepcionou” por não trazer todo o "misticismo" e mistério prometidos no início, se contradiz quando não aprova o que a trama apresentava de realismo mágico. Eles esperam uma verossimilhança na narrativa de O Sétimo Guardião: “O negócio da fonte eu já acho que é bem ficção mesmo (Risos), algo que não existe! O negócio dos guardião de um padre aceitar ser da irmandade né, uma religião que mistura com outras...sei lá, estranho” (Pâmela, 39). 
Ana (36) também salienta: "Isso não existe. O gato vira homem também, é muita ficção, demais. O negócio de um buraco sugar você lá. A fonte dando choque e sarando todas feridas e deixando jovem. Seria tão bom se fosse verdade, mas não existe!”. Vinícius (12) também não acreditava no gato que se transformava em homem e vice-versa, pois "o gato que dava um pulo lá e parava lá nos quinto dos inferno..." Para ele, o melhor da telenovela era Luz, porque “além de ser uma pessoa boa, ela é linda”, o jovem também gosta da atriz Marina Ruy Barbosa.

Em todos os retratos, aparecem também as questões relacionadas ao trabalho, ou melhor, à falta de trabalho na telenovela, pois, para os informantes, este tipo de ação, “importante na vida das pessoas" não era mostrado, além do que era apresentado sobre o machismo e o preconceito, principalmente no núcleo da família de Nicolau e Afrodite. Os três informantes também ressaltam as relações familiares na trama, tanto na família de Nicolau quanto na de Valentina, por causa da relação de "amor e ódio" e "rejeição" que ela tinha com o filho.

\section{Família 2}

Assim como na Família 1, na Família 2, os membros também assistem à telenovela realizando atividades nos telefones celulares e também como na primeira família, isso é percebido mais pontualmente em Marina (16). Ela, entre todos os informantes das duas familias, é a mais ativa nas redes. A jovem conversa pelo WhatsApp com os amigos e acessa seu Twitter e Instagram. Pouco curtia e compartilhava algo sobre a telenovela, e isto acontecia tanto no momento em que a trama estava no ar ou depois, mas, na maioria das vezes, as interações sobre $O$ Sétimo Guardião eram relacionadas às críticas à história ou aos atores e atrizes, pois Marina (16) gosta de Caio Blat e Marina Ruy Barbosa. Ela conta: “Eu ia atrás de algo sobre o ator, não por causa da novela. Porque o enredo eu achava bem estranho, bem fraquinho". Nas redes sociais da jovem, os assuntos que mais aparecem são os sobre política, pois, como já comentamos, ela é contrária ao governo atual, sobre feminismo, e fotos sobre animais, pois Marina (16) adora os "bichinhos". O que mais aparece quanto à ficção, são curtidas e compartilhamentos acerca das séries que ela assiste e gosta, como Game of Thrones, por exemplo. 
Edna (52) mexe no celular quando está assistindo à telenovela, mas pouco, ela costuma fazer isso quando não "tem nada mais para fazer, daí perco tempo no celular". Além do mais, a informante diz que, por causa da sua "geração", não tem muita competência para realizar muitas atividades nas redes e que aderiu a tais redes apenas por uma demanda da atualidade: “Às vezes, as pessoas falam assim: Ai tu não responde, ai tu não curte nada, tu não posta nada! Daí eu falo: Ah eu já fiz o troço, não me cobrem!" (Risos) (Edna, 52). Fala que, por inúmeras vezes, posta "os troços errados" e que a filha não tem "muita paciência" para ensinar. Portanto, a mulher nunca posta, compartilha ou curte postagens relacionadas à telenovela, pois elas não "vinham muito na minha rede social”, porque não eram relacionadas a assuntos de seu interesse. De vez em quando, Edna (52) vê algum ator ou atriz e "daí eu penso ah o que esse ator já fez e tal...aquele das calcinhas...a Marina gosta muito do Caio Blat, daí a gente ia pesquisar o ator, para saber sobre ele, mas no Google”. Suas postagens, compartilhamentos e curtidas versam sobre política e feminismo. 
Figura 51: Exemplo de atividades nas redes sociais - Marina
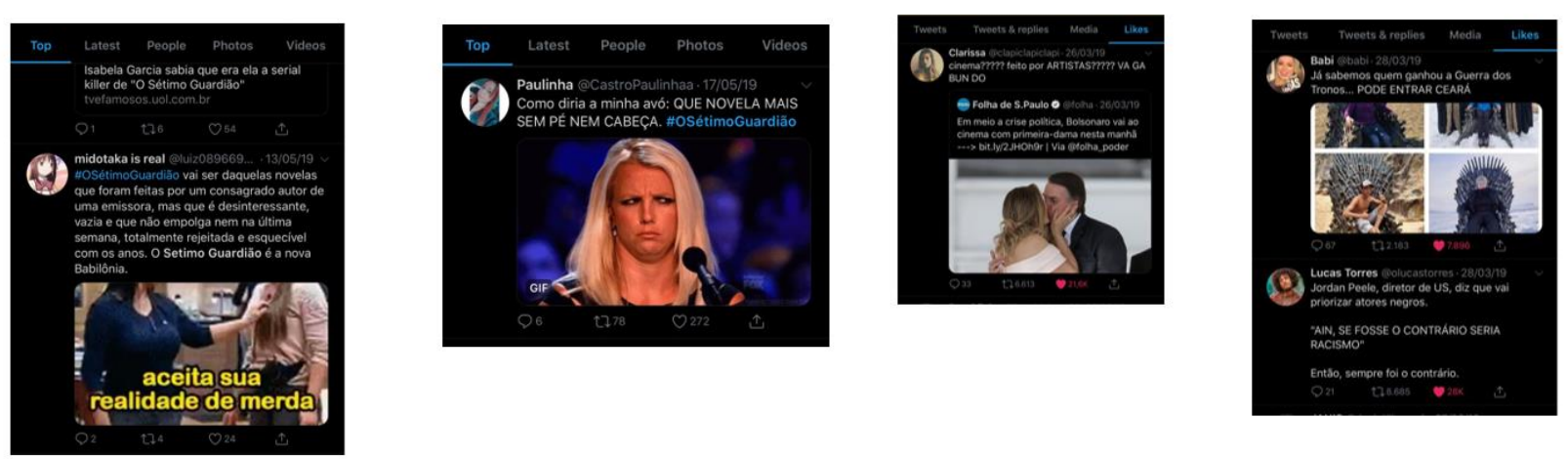

Fonte: Redes Sociais da informante

Figura 52: Exemplo de atividades nas redes sociais - Edna
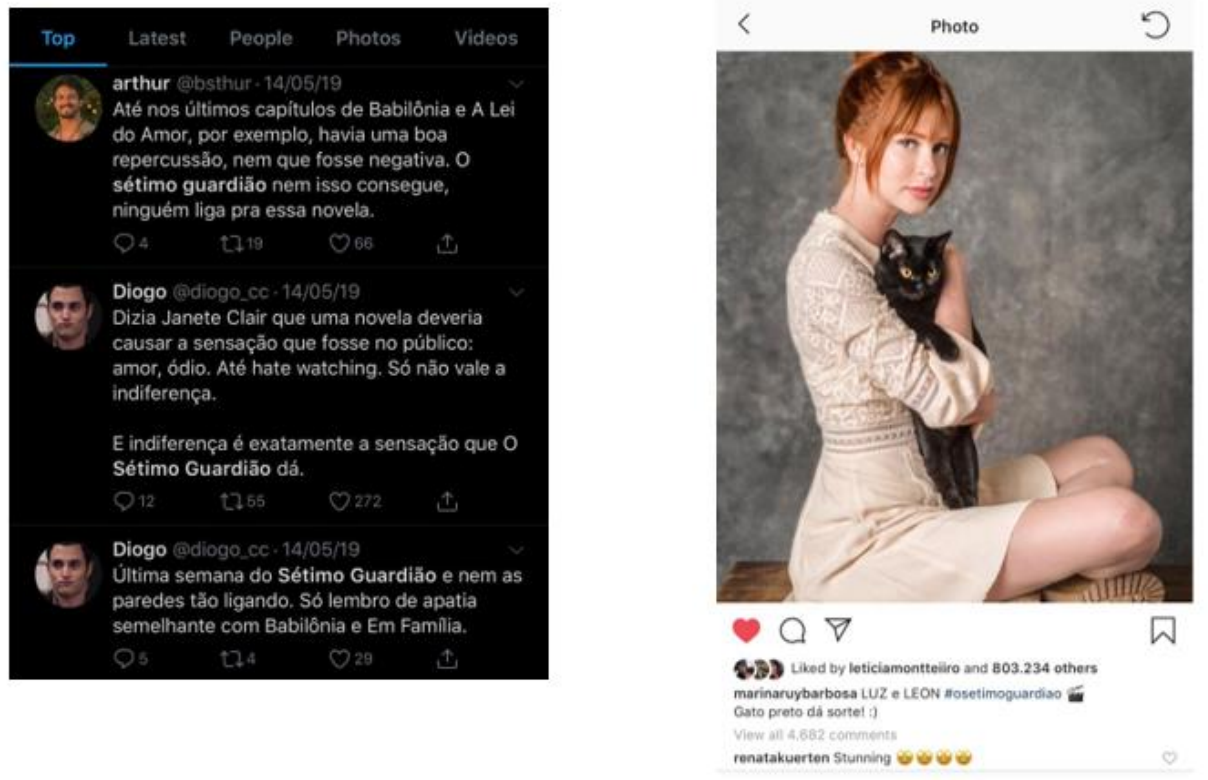

Fonte: Redes Sociais da informante 
Figura 53: Exemplo de atividades nas redes sociais - Edna

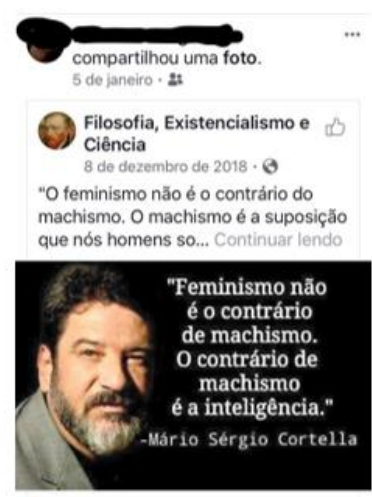

02

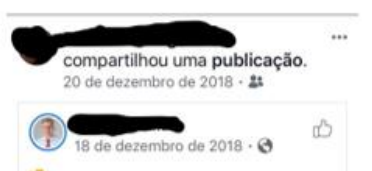

\section{E no final da} história, Jair não era honesto, João não era de Deus e Moro não era contra corrupção.

Fonte: Redes Sociais da informante

Portanto, observamos que a assistência da telenovela também foi reconfigurada devido à nova ambiência comunicacional, no tocante à capacidade multitarefa das receptoras. Conforme a tipologia de fãs (LOPES e MUNGIOLI, 2011), a mãe é espectadora porque apenas assiste, lê e ouve os conteúdos sobre telenovela que estão na mídia e Marina (16) flutua entre espectadora e compartilhadora por divulgar alguns conteúdos entre seus pares.

Sobre as questões concernentes à telenovela enquanto narrativa ficcional de $O$ Sétimo Guardião, e tudo o que engloba a trama, apresentamos o retrato obtido a partir do que foi observado na família dentro do conjunto tecnicidades. Segue: 
Figura 54: Retrato do documento sobre a telenovela - Marina

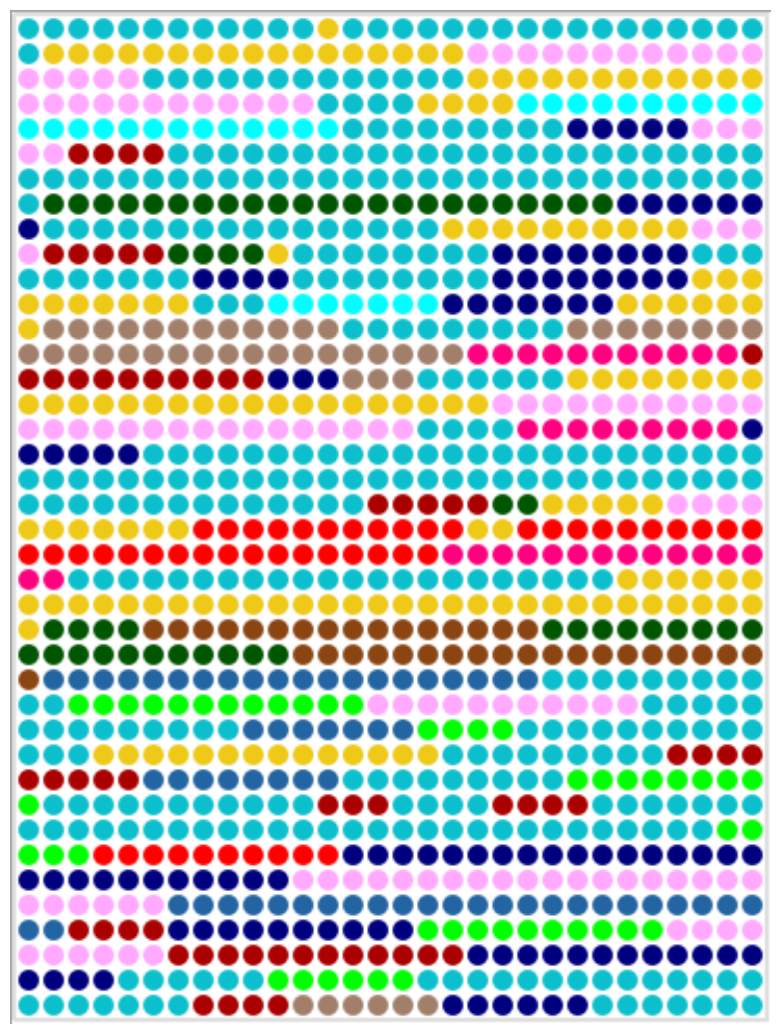

Fonte: Elaborado pela autora no Maxqda

Figura 55: Retrato do documento sobre a telenovela - Edna

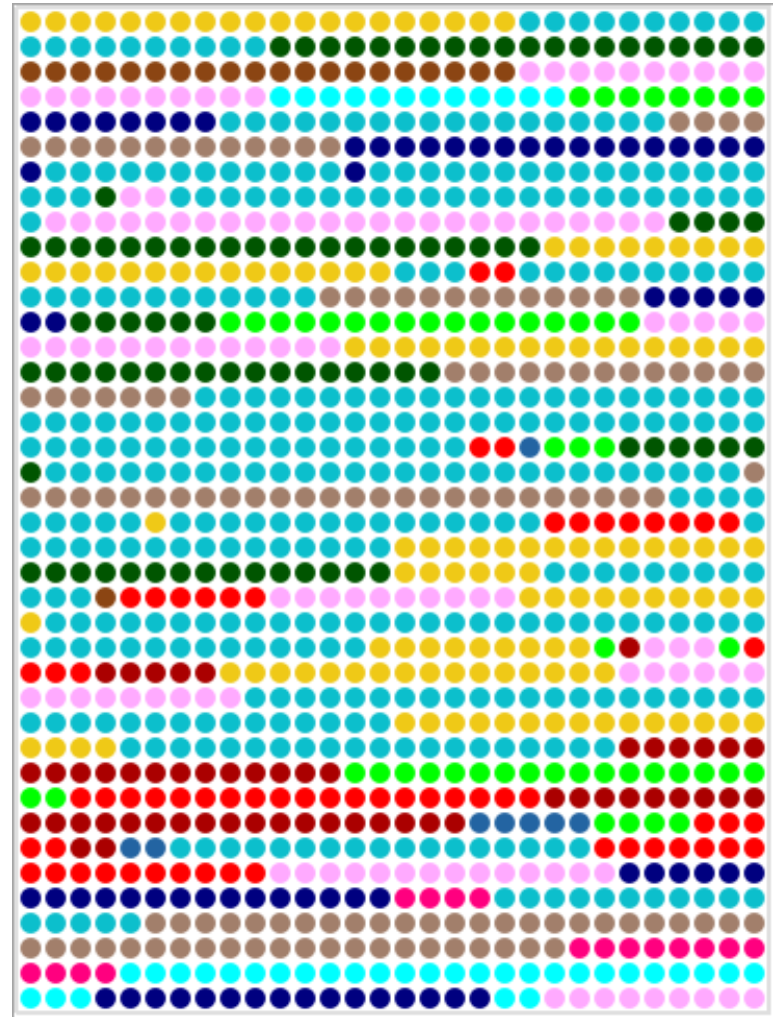

Fonte: Elaborado pela autora no Maxqda 


\section{Legenda dos códigos}

\begin{tabular}{cl}
\hline Cor & Código \\
\hline & Twitter \\
\hline$\bullet$ & Distinção \\
\hline$\bullet$ & Infância \\
\hline & Geracional \\
\hline$\bullet$ & WhatsApp \\
\hline$\bullet$ & Técnica \\
\hline & Facebook \\
\hline$\bullet$ & Emoções \\
\hline & Instagram \\
\hline$\bullet$ & Pertencimento de \\
& classe \\
\hline$\bullet$ & Emprego \\
\hline$\bullet$ & Relações \\
& interpessoais \\
\hline$\bullet$ & Relações amorosas \\
\hline$\bullet$ & Cotidiano familiar \\
\hline$\bullet$ & Cidadania \\
\hline$\bullet$ & Refeições \\
\hline & Assistência \\
\hline$\bullet$ & Econômico \\
\hline$\bullet$ & Relação com a \\
& Telenovela \\
\hline$\bullet$ & Religião \\
\hline$\bullet$ & Geração \\
\hline$\bullet$ & Consumo de mídia \\
\hline$\bullet$ & Roteiro e Texto \\
\hline$\bullet$ & Lazer \\
\hline$\bullet$ & Relações de Gênero \\
\hline$\bullet$ & Política \\
\hline$\bullet$ & Educação \\
\hline$\bullet$ & Relações familiares \\
\hline$\bullet$ & Trabalho \\
\hline$\bullet$ & Sexualidade \\
\hline & \\
\hline
\end{tabular}

Desta forma, podemos analisar que, como na Família 1, as questões relacionadas ao Roteiro e Texto da telenovela foram muito comentadas pelas informantes da Família 2. Elas também se decepcionaram com $O$ Sétimo Guardião após ela ter ido ao ar, pois esperavam mais cenas e articulações sobre o realismo mágico, prometido antes do início da trama:

No início eu achei legal porque me pareceu realismo fantástico, aquela história do gato e tal. Porque eu gosto de coisa assim de 
suspense, de mistério. Então saber o que era a fonte, do poder dela, mas depois ficou aquela da Marina Ruy Barbosa, chataaaa...e também no início tinha aquela disputa por ela daquele meio mala, o Loreto né...mas no final assim ele virou um moço porque ele se converteu a bom moço pelo amor dela... muito nhe nhe nhe (Edna, 52).

Relevante ressaltar, na fala acima de Edna (52), a concepção que ela e a filha têm sobre os protagonistas "mocinhos" das telenovelas, típicos de melodramas tradicionais. Elas não gostam desse tipo de personagens: "Muito romantiquinha... não gosto dessas novelas assim. Era muito amor envolvido, ou muito amor ou muito ódio! E não é assim que as coisas funcionam, muito chato!” (Marina, 16). A mãe acrescenta: "Não gosto da heroína que está ali para se doar e salvar todo mundo, que vai sofrer por um amor, entediante”. (Edna, 52). Elas, diferente das informantes da Familia 1, aprovaram que, no final da trama, Luz não terminou com Gabriel, num "final feliz":

Isso dela ter ficado sozinha, a gente gostou! Porque o Gabriel era um bosta e depois morreu para salvar ela, e o Júnior era chato e ela não gostava muito dele. Acho que tá certo, a mulher precisa de um diploma para ficar feliz e não de alguém. Muito viajado essa história de arqueóloga, mas eu gostei porque pelo menos ela teve um diploma (Marina, 16).

Ainda sobre a narrativa e o roteiro da telenovela, a familia achou que o autor "se perdeu no meio do caminho", pois, em vez de concentrar a história na fonte, levou a trama para os assassinatos: "Eles desvirtuaram muito, foi tanto que aquela fonte secou! Eles cagaram para fonte e começaram a matar gente do nada! Eu acho que eles começaram a matar gente porque tinha que ter alguma coisa na novela porque nada fazia sentido!” (Marina, 16).

Mas, na visão das receptoras, a história de O Sétimo Guardião, misturava suspense e comicidade, extrapolando o mote da fonte e a irmandade de guardiões, colocando em voga assuntos da atualidade, mesmo que de forma "caricaturizada" e "exagerada":

Focou bem nos conflitos das relações humanas, porque tinham pessoas representando papéis distintos da sociedade. O prefeito corrupto, a religiosa extremista, as relações homofóbicas, o preconceito com a alcoólatra, preconceito com gay, e na verdade ele era só um dançarino, o filho, relação de poder do marido sobre a mulher que depois se rebelou. E como pano de fundo assimo mistério 
do, místico da fonte, do que seria um poder superior que teria ali vagando sob aquele ambiente (Edna, 52 ).

Ainda que não gostassem do roteiro e do texto da telenovela, a família pontua que, em termos técnicos, mesmo que, segundo elas, sem ter a competência para analisar tais quesitos, a telenovela foi bem elaborada, "como todas as outras novelas da Globo", e elogiam as imagens, os efeitos e os atores escalados:

Os atores dessa novela eram bons, tinha um elenco bem legal, bem consistente. Lilia Cabral, uma lady ela, chiquérrima! Tony Ramos, outro ótimo. Aquele o pai do Bebeto um baita ator também. Flávia Alessandra lindíssima! Essa novela era para ser um estrondo com tanto ator bom, mas tudo diluído, sabe? Eu acho que perdeu a essência dos personagens! (Edna, 52).

Os retratos ainda revelam que a família apontou, ainda que de forma mais diluída, questões quanto as relações familiares e de gênero, especialmente no núcleo de Nicolau e Afrodite, conforme já relatamos, e ainda sobre política. Os comentários, assim como na Família 1, são coerentes com a visão de mundo e o cotidiano dos receptores. 


\section{CONSIDERAÇÕES FINAIS}

É chegada a hora de colocar um ponto final. Mas, ao fim do longo processo de construção do conhecimento que é uma pesquisa de doutorado, o que tem são, sim, algumas respostas, mas um número ainda maior de perguntas. $\mathrm{O}$ que, epistemologicamente falando, é um bom sinal, pois, ao invés de um fim, este é apenas o ponto de partida e novas pesquisas surgirão a partir dessa.

Assim, adotamos a perspectiva dos estudos sobre a cultura no âmbito latinoamericano que consideram os modos populares de produção e de recepção sem deslegitimá-los (PEREIRA, 2015), para realizar uma releitura e atualização, através do olhar da pesquisadora, do clássico livro de recepção Vivendo com a telenovela mediações, recepção, teleficcionalidade, (LOPES, BORELLI e RESENDE, 2002) levando em consideração o ecossistema comunicacional atual proporcionado pelas novas tecnologias com o ambiente transmidia e a convergência (JENKINS, 2009). Ainda partilhamos da ideia de que o pesquisador não é apenas um observador neutro, ele é "um sujeito político e moral" (ESCOSTEGUY, 2010, p. 53) e de que é essencial problematizar também a reconfiguração da comunicação na contemporaneidade devido às novas tecnologias.

Desta forma, iniciamos a tese situando o nosso objeto de pesquisa e a importância que a telenovela tem no Brasil sendo "narrativa da nação" (LOPES, 2003) e "recurso comunicativo" (LOPES, 2009) e reconhecendo que ela é capaz também de construir imaginários, identidades e fazer parte da partilha de sensibilidades. Além do mais, a telenovela "é um produto de uma sinergia imprevista entre diferentes agendas criativas, políticas e comerciais. Os procedimentos de construção da audiência são um elemento intrínseco à dinâmica da elaboração de novelas" (HAMBURGUER, 2005, p. 40). Pontuamos aspectos históricos e as características que fazem dela o produto cultural mais relevante do nosso país, mesmo com todas as opções disponibilizadas pelas novas tecnologias e novos formatos de serialidade.

Discorremos também sobre a Teoria Barberiana da Comunicação, norteadora de nossa pesquisa e de como o pensamento complexo de Martín-Barbero se faz cada vez mais atual nos estudos de Comunicação, além de trabalharmos seus Mapas das Mediações como concepção teórica -metodológica e epistemológica na investigação da recepção da telenovela em época transmídia. Os Mapas foram mobilizados e articulados 
porque "[...] dão conta da complexidade das relações constitutivas da comunicação na cultura, pois os meios passaram a ser um espaço chave de condensação e intersecção da produção e do consumo cultural, enquanto catalisam hoje algumas das mais intensas redes de poder" (Martín-Barbero, 2004, p. 239, tradução nossa) ${ }^{68}$. Reafirmamos ainda que "a recepção da telenovela traduz-se numa experiência cultural e de comunicação que enseja uma pesquisa que possa combinar contexto e leitura da recepção "(LOPES, BORELLI e RESENDE, 2002, p. 23, grifos das autoras).

Pontuamos e discutimos que a classe social deve ser levada em consideração em um estudo de recepção porque ela é essencial na conformação das identidades dos agentes, na visão que eles têm de mundo e de como estas vão colaborar para o sentido, os usos e as apropriações que fazem da telenovela. Ademais, ao ser observada a partir do habitus de classe, a prática cotidiana revela sua originalidade e sistematicidade, expressando a ordem social e estrutural (MARTÍN-BARBERO, 2003b) e se revela indispensável de ser discutida em um país extremamente desigual como o Brasil, onde se fala em "nova classe média" sem aprofundar o termo, em vez de admitir que esta nada mais é que uma classe trabalhadora com protagonismo social e político (CHAUI, 2014), como confirmamos em nossa pesquisa.

Então, nossa primeira hipótese teórica era $O$ inequívoco caráter transdisciplinar do campo da Comunicação e o caráter histórico da globalização e da tecnicidade exigem reconfigurações prementes da pesquisa de comunicação, em geral, e da pesquisa de recepção, em particular. Ela se confirmou, pois as novas tecnologias criaram um novo ecossistema comunicacional em que tanto a produção quanto a recepção foram ampliadas e ressignificadas. E o baixo número de estudos sobre a recepção da telenovela e internet/transmídia/ convergência demonstra que o tema deve ser mais investigado e discutido pelos pesquisadores do país. A nossa segunda hipótese teórica era de que a transdisciplinaridade da Comunicação demanda estudos de cunho complexo e o uso de estratégia multimetodológica na pesquisa de recepção. Ela também foi confirmada por termos tido a necessidade de pensar a Comunicação com base em um grande leque de autores, que obviamente tinham pensamento que dialogavam. Então, mobilizar esse vasto número de autores e teorias se mostrou

\footnotetext{
${ }^{68}$ No original: “ [...] dan cuenta de la complejidad en las relaciones constitutivas de la comunicación en la cultura, pues los medios pasaron a ser un espacio clave de condensación e intersección de la producción y del consumo cultural, mientras catalizan hoy algunas de las más intensas redes de poder”.
} 
indispensável para que pudéssemos, primeiro teorizar para depois fazermos a análise e interpretação da complexa teia de recepção de telenovela construída na contemporaneidade. Assim, a elaboração do nosso protocolo multimetodológico permitiu a apreensão desta recepção nos dias de hoje. A terceira e última hipótese teórica foi de que a classe social continua a mediação estruturante na recepção da telenovela no ambiente transmídia. Esta hipótese também foi confirmada na pesquisa de campo com os receptores, pois tal mediação perpassa os modos como eles veem, leem, usam e se apropriam da telenovela.

Tivemos quatro hipóteses empíricas, a primeira era de que a proposta das mediações de Jesús Martín-Barbero atualiza-se no mapa das mediações como recurso teórico e metodológico essencial para a pesquisa empírica de recepção da telenovela. $\mathrm{E}$ constatamos que os Mapas do autor realmente são atuais e podem ser articulados entre si de modo a proporcionar a investigação de como acontece a recepção da telenovela em tempos de transmídia e convergência. Apesar do grande esforço no que diz respeito à operacionalização desses mapas no empírico, visto que são amplos e abertos, permitindo diversos usos e interpretações, agora por parte do pesquisador, eles se mostram eficientes. A segunda hipótese empírica era de que a recepção tradicional de telenovela sofreu reconfigurações em função do ambiente transmídia e de convergência. De fato ela sofreu reconfigurações, pois, apesar da televisão e da telenovela ainda fazerem parte do cotidiano das pessoas, elas não são mais protagonistas. A telenovela divide o espaço com o telefone celular por meio da internet e, especialmente, das redes sociais.

A terceira hipótese era de que a assistência familiar da telenovela está em declínio e outras ritualidades assomam. Esta hipótese foi confirmada em partes, porque é verdade que outras ritualidades se assomam, por conta do que recém mencionamos, a internet e as redes sociais. Mas a assistência em família não está em declínio porque os receptores continuam assistindo à telenovela no espaço doméstico. A diferença é de que outras atividades são realizadas concomitantemente ao momento em que a telenovela está no ar, não é em todos os momentos que a família inteira se reúne sentada no sofá e assiste apenas à telenovela, sem fazer nada mais, como antigamente.

A quarta hipótese era de que a sociabilidade virtual nas mídias sociais é a atual responsável pela continuidade das conversações sobre a telenovela, do repertório compartilhado e da nação imaginada. Na nossa pesquisa, esta hipótese também foi 
confirmada com ressalvas, já que apenas uma de nossas informantes dava continuidade aos conteúdos sobre a telenovela no ambiente virtual. Mesmo assim, isso não era feito com frequência. Os outros informantes das duas familias, algumas vezes viam o que estava nas redes sobre a telenovela, mas não interagiam com tal conteúdo. Portanto, podemos afirmar que comprovamos os diferentes níveis de engajamento propostos por meio da tipologia de fãs (LOPES e MUNGIOLI, 2011), onde nossos receptores são, na sua maioria, espectadores, ou seja, leem, assistem e ouvem os conteúdos sobre a telenovela que estão no ambiente virtual e compartilhadores, pois divulgam esse conteúdo entre os seus pares.

Os objetivos gerais da nossa pesquisa eram teóricos e epistemológicos. Os teóricos versavam sobre contribuir para o avanço teórico e metodológico de estudos de recepção de ficção televisiva relacionada à transmídia e convergência. Também colaborar para o resgate do caráter político das pesquisas de comunicação, principalmente aquelas que discutem as questões de empoderamento do receptor frente à perspectiva contemporânea da comunicação dentro do ecossistema transmidiático e convergente. Foram alcançados, após um longo percurso traçado e também um grande esforço. Consideramos que nossa contribuição está no fato de que trazemos mais uma investigação sobre o tema, já que ainda é pouco estudado. Além disso, elaboramos um protocolo multimetodógico atualizado com base nas demandas impostas pelas novas tecnologias, onde, inclusive, utilizamos um software que possui uma infinidade de funções capaz de auxiliar nas pesquisas qualitativas. O resgate do caráter político das pesquisas da comunicação estão não só no que concerne ao empoderamento do receptor frente ao ecossistema midiático, pois demos voz e o mostramos na nossa pesquisa, além de discutirmos sobre os usos e apropriações que fazem destas novas tecnologias. Mas também porque, como poucos estudos do campo fazem, discutimos e refletimos sobre a questão da classe social dentro desse contexto receptivo, pois consideramos em nossa análise a classe que os informantes fazem parte, importante para a conformação de como veem e leem a mídia.

$\mathrm{O}$ outro objetivo geral, de caráter mais epistemológico, foi de explorar $e$ readequar teórica e metodologicamente a recepção de uma telenovela no atual ambiente transmídia e de convergência, a partir da releitura do estudo clássico de recepção Vivendo com a telenovela - mediações, recepção, teleficcionalidade (LOPES, BORELLI e RESENDE, 2002), realizado há 18 anos quando não existia tal realidade. 
Por meio dele, logramos readequar tanto teórica quanto metodologicamente a recepção da telenovela no atual ambiente transmídia e de convergência porque trouxemos, na perspectiva teórica, atualizações tanto relacionadas aos Mapas das Mediações, já que novos mapas foram propostos por Martín-Barbero, quanto a toda discussão teórica sobre transmídia e convergência. Acreditamos também que avançamos nas questões relacionadas à classe social, no modo como classificar e compor a nossa amostra de pesquisa empírica, visto que, no estudo de 2002, o principal critério utilizado foi o bairro, e nós levamos em consideração a ocupação dos informantes. Ainda sobre a classe, debatemos o termo muito utilizado recentemente, e à revelia, "nova classe média". Outra constatação é de que a classe média baixa de hoje em dia, amostra representante da classe popular estudada por nós, não é mesma de quando a pesquisa inspiração foi realizada. Uma das mudanças está no aumento do poder aquisitivo dessas pessoas, maior se comparado com aquelas de 2002, afinal, como já afirmamos, a classe trabalhadora ascendeu. Destacamos, ainda, o uso do software Maxqda Analitycs Pro 2018, visto que o programa é mais completo e avançado do que o utilizado há 18 anos, possibilitando inúmeras formas de análise dos nossos dados.

Como objetivos práticos, analisamos como a recepção da telenovela, basicamente de assistência coletiva familiar, foi reconfigurada pela transmidiação e convergência. Mais especificamente, propomo-nos a desvendar de que maneira isso acontece em duas famílias de diferentes classes sociais. E, como já declaramos, detectamos que a recepção da telenovela foi reconfigurada, e o sofá, local primordial de assistência da televisão e da telenovela, também foi expandido e, hoje, não é só os membros da familia compartilham a assistência do programa ficcional, mas outras pessoas que fazem parte da ampla rede de relacionamento de cada receptor, proporcionada pela internet. No caso da nossa pesquisa, encontramos uma audiência multitela e multiplataforma, e não propriamente transmídia pelo fato de que apenas uma receptora expande a telenovela para o ambiente virtual.

Tínhamos cinco objetivos específicos, o primeiro deles era o de explorar teórica $e$ metodologicamente a recepção da telenovela em tempos de transmídia $e$ convergência. E por tudo o que já comentamos acima, acreditamos que cumprimos com esse objetivo na elaboração do nosso protocolo multimetodológico, na mobilização e articulação dos diferentes Mapas das Mediações, na maneira como, mesmo atualizando uma pesquisa já realizada, pudemos colocar sob o foco do nosso olhar tudo o que foi 
realizado na pesquisa atual e ainda porque percebemos que o receptor da telenovela pode ter diferentes níveis de engajamento com a trama nas redes e, ainda sim, fazer parte do novo ecossistema comunicacional. O segundo objetivo específico era de transpor, atualizar e readequar o protocolo metodológico de pesquisa utilizado no livro Vivendo com a Telenovela - mediações, recepção, teleficcionalidade, observando a recepção da telenovela $O$ Sétimo Guardião, em duas famílias, uma de classe popular (classe média baixa) e outra de classe alta (classe média alta). Quanto a esse objetivo, também já explicitamos que cumprimos, pois a pesquisa de campo foi realizada com as duas famílias durante o período em que a telenovela foi ao ar e, para que ela fosse realizada, transpusemos, atualizamos e readequamos o protocolo multimetodológico, retirando e acrescentando mediações e técnicas de coleta capazes de suprir as demandas da nossa pesquisa. Pudemos verificar que nenhuma das duas famílias estudadas gostou da telenovela assistida, pois fizeram duras críticas ao roteiro e ao texto da trama.

$\mathrm{O}$ terceiro objetivo específico foi o de analisar como se dá a assistência da telenovela pelas duas famílias, se a assistência em família ainda é o principal local de recepção e se dispositivos transmídia estão presentes nesta recepção. Também, nas nossas hipóteses, já falamos quais foram os resultados quanto à assistência, mas é possível acrescentar que as inúmeras opções e apelo advindos de outras plataformas tecnológicas fazem com que a telenovela não seja assistida de forma exclusiva pelos receptores, como era feito em outras épocas, em que o tempo era mais lento e as opções analógicas. Hoje o ecossistema comunicacional e o contexto contemporâneo exigem pessoas multitarefas e, consequentemente, receptores multitarefas e multiplatafórmicos. Ademais, é possível aferir que se a telenovela tivesse agradado aos receptores, talvez as idas à internet do celular, mesmo que presentes, teriam sido reduzidas. O nosso quarto objetivo específico foi verificar se a recepção das diferentes gerações acontece de maneira diferenciada devido às novas tecnologias. Sobre isto, foi possível apurar que os usos e apropriações da mídia e das tecnologias disponíveis são diferentes conforme as gerações e variam de intensidade com a idade dos receptores. Os jovens têm mais competência e possuem a literacia para desenvolver as tarefas no ambiente virtual, ademais podemos afirmar que, apesar de assistirem à telenovela, os momentos de dispersão são inúmeros, especialmente por conta dos telefones celulares e de quem está "por trás deles". 
Tínhamos como último objetivo específico examinar se a classe social continua estruturante nos usos e apropriações que os receptores fazem da telenovela, mesmo com o ambiente transmídia e de convergência. Observamos que a classe social continua estruturante e perpassa todas as ações, as falas, o estilo de vida, os gostos, os usos e as apropriações que os receptores fazem da telenovela. Importante ressaltar ainda que a subjetividade dos agentes e as questões de gênero, por serem famílias chefiadas por mulheres, também atravessam sua visão de mundo e o modo como a recepção da telenovela acontecesse. Aferimos ainda que a familia de classe alta não aprova os "mocinhos" e os "finais felizes", típicos do melodrama e do folhetim tradicional. Já a família de classe baixa espera por esses finais. Ambas as classes têm visão crítica sobre a telenovela e sobre os assuntos tratados por ela, mas o que chama atenção dos diferentes receptores tem relação com a classe à qual pertencem e sua realidade, bem como com os seus capitais cultural e econômico acumulados. A família de classe popular atenta, em maior proporção, ao que tem relação direta com o melodrama e folhetim e as tramas centrais da narrativa ficcional. Já a família de classe alta, apesar de atentar para a trama central, aponta e aprofunda questões secundárias na trama, mas que tenham importância dentro do contexto atual e político, como as discussões de relações de gênero e preconceito. Ainda foi possível detectar que a classe popular se projeta na trama, inclusive na maneira como contam suas histórias, explorando a dramaticidade e os detalhes. E faz relação com a vida real e vida ficcional, por mais que preze pela verossimilhança na história. Já os receptores de classe alta não fazem relação da trama com o seu dia a dia e preferem entrar no universo ficcional conforme o que foi proposto pelo autor, por isso estavam tão decepcionados com o apagamento do realismo mágico ao longo da trama, já que era o gênero o que chamou atenção para a assistência da telenovela. O jogo de distinção de classe social, nas duas famílias, era presente, e se manifestava tanto com relação à recepção da telenovela como no vivido.

Terminamos esse trabalho com a certeza de que, após o que foi percorrido, temos ainda mais dúvidas, inquietações e vontade de continuar estudando o vasto, apaixonante e profícuo subcampo da recepção, certos de que as questões de classe social sempre nos acompanharão e serão mote de articulação com a comunicação devido ao compromisso social que assumimos quando nos propusemos a pesquisar o campo da Comunicação com a lente dos estudos da cultura na América Latina. Esperamos que as 
reflexões trazidas nesse texto possam de alguma forma auxiliar nossos pares em suas investigações do complexo e transdisciplinar campo comunicativo. 


\section{REFERÊNCIAS}

ALMEIDA, M. R. Espectorialidade e materialidade na televisão multiplataforma: uma análise do programa Superstar.In: SIMPÓSIO NACIONAL ABCIBER, VIII, 2014. São Paulo. Anais... ABCiber: São Paulo, p.1-15, 2014.

AQUINO, M. C.; PUHL, P. Vale tudo no Twitter: a visibilidade da ficção televisiva em tempos de convergência midiática. Alceu, v. 12, n. 23, p. 34-48, 2011.

ARISTÓTELES. Ética a Nicômaco. Bauru: Edipro, 2009.

BACCEGA, M. A. e CASTRO, G. Espectadores, fãs e supernoveleiros: Velho Chico na cultura participativa. In: LOPES, M.I.V. Por uma teoria de fãs da fícção televisiva II: práticas de fãs no ambiente da cultura participativa. Porto Alegre: Sulina, 2017.

BACHELARD, G. Conhecimento comum e conhecimento científico. Tempo Brasileiro. São Paulo, n. 28, p. 47-56, jan./mar., 1972.

BAKHTIN, M. A cultura popular na Idade Média e no Renascimento. São Paulo/Brasília: Hucitec, 1987.

BAKHTIN, M. A cultura popular na Idade Média e no Renascimento: o contexto de François Rabelais. São Paulo: Hucitec, 2008.

BARDIN, L. Análise de conteúdo. Tradução: Luís Antero Reto e Augusto Pinheiro. Lisboa: Edições 70, 2009.

BARROS FILHO, Clóvis; MARTINO, Luís Mauro Sá. O habitus na comunicação. São Paulo: Paulus, 2003.

BARTHES, R. Elements of Semiology. New York: Hill and Wang, The Noonday Press (tradução do original francês, 1964), 1967.

BAUER, M. W; GASKELL, G. Pesquisa qualitativa com texto, imagem e som: um manual prático. Petrópolis: Vozes, 2002.

BEASLEY-MURRAY, J. Cultural studies questionnaire. Entrevista com Jesús MartínBarbero. Journal of Latin American Cultural Studies. Abingdon, v. 10, n. 2, p. 223230, 2001.

BIELBY, D.; HARRINGTON, C. L.; BIELBY, W. Whose stories are they? Fans' engagement with soap opera narratives in three sites of fan activity. Journal of Broadcasting and Electronic Media 43 (1), p. 35-51, 1999.

BONIN, J. A.; MORIGI, V. J. Ciudadanía en las interrelaciones entre comunicación, medios y culturas. In: RINCÓN, O. (ed.); JACKS, N.; SCHIMITZ, D.; WOTTRICH, L. (orgs.) Un nuevo mapa para investigar la mutación cultural. Diálogo con la propuesta de Jesús Martín-Barbero. Tradução: Fabrícia Reginatto. Quito: CIESPAL, 2019. 
BOOTH, P. Digital fandom: new media studies. New York: Peter Lang, 2010.

BORGES BRANDÃO, G.; FARIA, M. C. et al. Fãs de Liberdade, Liberdade: curadoria e remixagem na social TV In: LOPES, M.I.V. (org.) A construção de mundos na ficção televisiva brasileira. Porto Alegre: Sulina, 2019.

BORTOlON, B.; REGATTIERI, L. L.; MALINI, F. L. L. Avenida Brasil: eu assisti, você assistiu e a rede estava lá. In: XVIII Congresso de Ciências da Comunicação da Região Sudeste. Bauru - SP: Intercom, 2013. p. 1-15.

BOSI, E. Entrevista. In: BRUCK, M. S. Memória: enraizar-se é um direito fundamental do ser humano. Dispositiva, v.1, n.2, p. 196-199, nov.2012 / abr. 2013.

BOSI, E. Memória e Sociedade. Lembranças de velhos. São Paulo, EDUSP, v. 1., 1987.

BOURDIEU, P. (coord.). A miséria do mundo. Petrópolis: Vozes, 1997.

BOURDIEU, P. A distinção - crítica social do julgamento. Tradução Daniela Kern; Guilherme, F. Teixeira. São Paulo: Edusp; Porto Alegre: Zouk, 2007.

BOURDIEU, P. Capital simbólico e classes sociais. Novos estud. - CEBRAP [online]. n. 96 p. 105-115, 2013. Disponível em: http://www.scielo.br/scielo.php?script=sci_arttext\&pid=S0101$\underline{33002013000200008 \& \operatorname{lng}=e n \& n r m=i s o \& t \operatorname{lng}=p t}$ Acesso maio 2019.

BOURDIEU, P.; WACQUANT, L. An invitation to reflexive sociology. Chicago: The University of Chicago Press, 1992.

BRESSAN JUNIOR, M. A. A memória afetiva e os telespectadores: um estudo do canal viva. 2017. 179f. Tese (Doutorado em Comunicação). Pontifícia Universidade do Rio Grande do Sul, Porto Alegre, 2017.

BRIGNOL, L.; COGO, D.; MARTÍNEZ,S. L. Redes: dimensión epistemológica y mediación constitutiva de las mutaciones comunicacionales y culturales de nuestro tiempo. In: RINCÓN, O. (ed.); JACKS, N.; SCHIMITZ, D.; WOTTRICH, L. (orgs.) Un nuevo mapa para investigar la mutación cultural. Diálogo con la propuesta de Jesús Martín-Barbero. Tradução: Fabrícia Reginatto. Quito: CIESPAL, 2019.

CALDEIRA, T.P. do R. A política dos outros: o cotidiano dos moradores da periferia e o que pensam do poder e dos poderosos. São Paulo: Brasiliense, 1984.

CAMPEDELli, S. Y. A telenovela. São Paulo: Editora Ática, 1987.

CANATTA, F. TV e segunda tela: uma análise do horário nobre no Twitter. 2014, 126f. Dissertação (Mestrado). Pontifícia Universidade do Rio Grande do Sul, Porto Alegre, 2014.

CARR, C. et. al. Interaction of interpersonal, peer, and media influence sources online: a research agenda for technology convergence. In: INTERNATIONAL COMMUNICATION ASSOCIATION - ICA, 58, 2008, Montreal, Quebec: Canada. Convergence of online influence sources. Proceedings. Montreal: CA, p. 1-19, 2008. 
CASTELLS, M. A era da informação: economia, sociedade e cultura . O fim do milénio. Lisboa: Fundação Calouste Gulbenkian, 2003.

CASTELLS, M. A galáxia Internet: reflexões sobre Internet, negócios e sociedade. Lisboa: Fundação Calouste Gulbenkian, 2004.

CASTELLS, M. Communication power. Oxford: University of Oxford Press, 2009.

CASTILHO, F. TELETUBE - Novo passeio pelos bosques da ficção televisiva. 2014. 328f. Tese (Doutorado em Ciências da Comunicação). Universidade de Coimbra, Coimbra, 2014.

CAVALCANTI, G. K. M. Televisão e redes sociais: configurações de TV Social em Malhação. 2016. 186f. Dissertação (Mestrado em Comunicação). Universidade Federal de Pernambuco, Recife, 2016.

CEVASCO, M. E. Para ler Raymond Williams. São Paulo: Paz e Terra, 2001.

CHACEL, M.C.da C. Audiência transmídia: uma proposta de conceituação a partir das telenovelas da Rede Globo. 2016. 181f. Tese (Doutorado em Comunicação). Universidade Federal de Pernambuco, Recife, 2016.

CHAUÍ, M. Prefácio. O mito da grande classe média: capitalismo e estrutura social. $1^{\mathrm{a}}$ ed. São Paulo: Boitempo, 2014.

CHIAMPI, I. O realismo maravilhoso. São Paulo: Perspectiva, 1980.

CHURCH, K.; OLIVEIRA, R. What's up with whatsapp?: comparing mobile instant messaging behaviors with traditional SMS. In: INTERNATIONAL CONFERENCE ON HUMAN-COMPUTER INTERACTION WITH MOBILE DEVICES AND SERVICES, 15th, Munich, Germany. Proceedings.... Munich, GR: ACM, 2013. p. 352-361, 2013.

COGO, D. Pesquisa em Recepção na América Latina: perspectivas teóricometodológicas. Incom. Barcelona, 2007. Disponível http://www.portalcomunicacion.com/uploads/pdf/48_por.pdf Acesso maio 2017.

COSTA, L. C. da. Classes médias e as desigualdades sociais no Brasil. In: BARTELT, D. D. (Org.). A "nova classe média" no Brasil como conceito e projeto político. Rio de Janeiro: Fundação Heinrich Böll, 2013.

COULDRY, N. Descobrindo a contínua realidade das mediações, ou redescobrindo a história de nosso campo de investigação. Matrizes, v. 12, n. 1, p. 35-38, jan./abr., 2018.

Debord, G. A Sociedade do Espetáculo. Lisboa: Edições Afrodite, 1997.

DELEUZE, G.; GUATTARI, F. Mil platôs - capitalismo e esquizofrenia, v. 1. Tradução de Aurélio Guerra Neto e Célia Pinto Costa. Rio de janeiro: Ed. 34, 1995.

DELLER, R. Twittering on: audience research and participation using Twitter. Participations: Journal of Audience \& Reception Studies, v. 8, n. 1, p. 216-245, 2011. 
DEPEXE, S. D. Distinção em 140 caracteres: classe social, telenovela e Twitter. 2015. 235f. Tese (Doutorado em Comunicação Midiática). Universidade Federal de Santa Maria, Santa Maria, 2015.

DESIDÉRIO, P. M. M. O discurso sobre a homossexualidade em Insensato Coração: ressonância nos comentários fragmentados discursivos de intemautas em webséries. 2013. 225f. Tese (Doutorado em Comunicação). Universidade de Brasîlia, Brasilia, 2013.

DEUZE, M. Convergence culture in the creative industries. International Journal of Cultural Studies, v. 10, n. 2, p. 243-263, 2007.

DOUGHTY, M.; ROWLAND, D.; LAWSON, S. Who is on your sofa? TV audience communities and second screening social networks. In: EUROITV, 10th, 2012, Berlin. Proceedings... Berlin: ACM, p. 79-86, 2012.

DUARTE, J. Entrevista em profundidade. In: DUARTE, J.; BARROS; A. (Orgs.). Métodos e técnicas de pesquisa em comunicação. São Paulo: Atlas, 2009.

DURKHEIM, E. A Divisão do Trabalho Social. v. II. Porto: Editorial Presença, 1984.

EAGLETON, T. Marx estava certo. Rio de Janeiro: Nova Fronteira, 2012.

ESCOSTEGUY, A. C. Cartografias dos estudos culturais: uma versão latinoamericana. Belo Horizonte: Autêntica, 2010.

ESCOSTEGUY, A.C. Estudos culturais latino-americanos e Jesús Martín- Barbero: mais afinidades do que disputas. Matrizes, v. 12, n. 1, p. 99-113, jan./abr., 2018.

EVANS, E. Character, audience agency and trans-media drama. Media, Culture and Society, v. 30, n. 1, 2008. Disponível em: http://eprints.nottingham.ac.uk/551/ Acesso em junho 2018.

EVANS, E. Transmedia Television: Audiences, New Media And Daily Life. Nova Iorque: Routledge, 2011.

FAUSTO NETO, A. Olhares sobre a recepção através das bordas da circulação. In: XVIII Encontro da Compós. Belo Horizonte: Compós, 2009. p. 1-13. Disponível em: Acesso em agosto de 2018.

FECHINE, Y. et al. TV social como estratégia de produção na ficção seriada da Globo: a controvérsia como recurso. In: LOPES, M.V. I. (org.) A construção de mundos na ficção televisiva brasileira. Porto Alegre: Sulina, 2019.

FECHINE, Y. et. al. Como pensar os conteúdos transmídias na teledramaturdia brasileira? Uma proposta de abordagem a partir das telenovelas da Globo. In: LOPES, M. I. V. (Org.) Estratégias de transmidiação na ficção televisiva brasileira. Porto Alegre: Sulina, 2013.

FECHINE, Y.; FIGUEIRÔA, A. Transmidiação: explorações conceituais a partir da telenovela brasileira. In: LOPES, M. I. V. (Org.) Ficção televisiva transmidiática no 
Brasil: plataformas, convergência, comunidades virtuais. Porto Alegre: Sulina, 2011.

FELIPPI, A. C. T. VILLELA, R.S., SILVEIRA, R.L.L. La Espacialidad: en el Mapa Comunicativo de la Cultura: producto social y condición del devenir. In: RINCÓN, O. (ed.); JACKS, N.; SCHIMITZ, D.; WOTTRICH, L. (orgs.) Un nuevo mapa para investigar la mutación cultural. Diálogo con la propuesta de Jesús Martín-Barbero. Tradução: Fabrícia Reginatto. Quito: CIESPAL, 2019.

FERNANDES, I. Memória da telenovela brasileira. São Paulo: Brasiliense, 1994.

FIGARO, R. Estudo de recepção: o mundo do trabalho como mediação da comunicação. Novos Olhares, n.6, $2^{\circ}$ semestre, p. 38- 51, 2000. Disponível em: file://CC:/Users/Tissiana/Documents/TISSIANA\%20UFSM/Projeto/JN/Figaro,\%20medi a\%C3\%A7\%C3\%A3o\%20e\%20trabalho.pdf Acesso em dezembro de 2019.

FIGARO, R.; GROHMANN, R. O conceito de classe social nos estudos de recepção brasileiros. In: XXII Encontro da Compós. Universidade Federal da Bahia: 04-07 de julho de 2013, p. 01-17.

FLEURY, S. A fabricação da classe média: projeto político para nova sociabilidade. In: BARTELT, D. D. (Org.). A "nova classe média" no Brasil como conceito e projeto político. Rio de Janeiro: Fundação Heinrich Böll, 2013.

FONSECA, C. Classe e a recusa etnográfica. In: BRITES, J; FONSECA, C. (Orgs.). Etnografias da Participação. Santa Cruz do Sul: EDUNISC, 2006.

FONSECA, C. Da família ao parentesco em sociedades complexas. Participação na Mesa Redonda $O$ lugar da familia na ciência contemporânea: desafios e tendências na pesquisa. Congresso Internacional Pesquisando a Familia, Florianópolis, 24-26 de abril. In: ALTHOFF, R.; ELSEN, I.; NITSCHKE, R. G. (Orgs.). Pesquisando a família: olhares contemporâneos. Florianópolis: Papa-livro editora, 2002.

FONSECA, C. Família, fofoca e honra. Etnografia de relações de gênero e violência em grupos populares. Porto Alegre: Editora da UFRGS, 2004.

FREIRE FILHO, J. Reinvenções da Resistência Juvenil: os estudos culturais e as micropolíticas do cotidiano. Rio de Janeiro: Mauad X, 2007.

FREIRE, C. P. Método de monitoramento de redes sociais. Epistemologia, técnicas e propostas de mineração de banco de dados para conteúdos gerados por fãs de telenovela em redes sociais. 2015. 399f. Tese (Doutorado em Ciências da Comunicação). Universidade de São Paulo, São Paulo, 2015.

FREIRE, D. O. de. Telenovela e identidade nacional no ciberespaço: explorações metodológicas da recepção internacional de Caminho das Índias em comunidades virtuais. 2010.167f. Dissertação (Mestrado em Ciências da Comunicação). Universidade de São Paulo, São Paulo, 2010.

GARCÍA CANCLINI, N. Leitores, espectadores, intemautas. São Paulo: Iluminuras, 2008. 
GENETTE, G. Paratexts: The Thresholds of Interpretation. Tradução: Jane E. Lewin. Cambridge: Cambridge University Press, 1997

GIDDENS, A. A transformação da intimidade. Sexualidade, amor \& erotismo nas sociedades modernas. Tradução Magda Lopes. São Paulo: UNESP, 1992.

GIRARDI JÚNIOR, L. De mediações em mediações: a questão da tecnicidade em Martín-Barbero. Matrizes, v. 12, n. 1, p. 115-172, jan./abr., 2018.

GOMES, I. M. M et al. Temporalidades Múltiplas: análise cultural dos videoclipes e da performance de Figueroas a partir dos mapas das mediações e das mutações culturais. Contracampo, Niterói, v. 36, n. 03, pp. 134-153, dez. 2017/ mar. 2018.

GOMES, M. Gilles Deleuze, Félix Guattari e Jacques Derrida. In: Dicionário de comunicação: escolas, teorias e autores. CITELLI, A. et al. (orgs.). São Paulo: Editora Contexto, 2014.

GORENDER, M. E. Serial killer: o novo héroi da pós-modernidade. Estudos de Psicanálise, Aracaju, n. 34, p. 117-122, dez., 2010.

GRAMSCI, A. Cadernos do Cárcere. Rio de Janeiro: Ed. Civilização Brasileira, 2002.

GRAY, J. Show Sold Separately: Promos, Spoilers and Other Media Paratexts. New York: New York University Press, 2010.

GROHMANN, R. A midiatização da nova classe média: identidades discursivas na revista IstoÉ Dinheiro. Rumores. São Paulo, n.16, v.8, jul./de z. 2014 . Dis p oníve $1 \quad$ e m: https $/ /$ www.researchgate.net/publication/286249487_A_midiatizacao_da_nova_classe_ media_identidades_discursivas_na_revista_IstoE_Dinheiro Acesso em julho de 2019.

GROHMANN, R. As classes sociais na comunicação: sentidos teóricos do conceito. 2016. 365f. Tese (Doutorado em Ciências da Comunicação). Universidade de São Paulo, São Paulo, 2016.

GUERRA, A. et al. Classe média. Desenvolvimento e crise. São Paulo: Cortez, 2006.

GUETTERMAN, T; CRESWELL, J. W.; KUCKARTZ, U. Using joint displays and Maxqda software to represent the results of mixed methods research. In: MC CRUDDEN, M. T.; SCHRAW, G.; BUCKENDAHL, C.W. Use of Visual Displays in Research and Testing: Coding, interpreting and reporting Data. A volum in: current perspective on cognition, learning and instruction. Charlotte: Information Age Publishing INC, 2015.

HALL, S. Da Diáspora: Identidades e Mediações Culturais. SOVIK, L. (Org.). Tradução: Adelaine La Guardia Resende, Ana Carolina Escosteguy, Cláudia Álvares, Francisco Rüdiger, Sayonara Amaral. Belo Horizonte: UFMG, 2006.

HAMBURGER, E. Política e novela. In: BUCCI, E. (org.). A TV aos 50. São Paulo: Editora Fundação Perseu Abramo, 2000. 
HAMBURGUER, E. O Brasil antenado: A sociedade da novela. Rio de Janeiro: Jorge Zahar Ed., 2005.

HAMBURGUER, E.; GOZZI, G.C. Mediação transnacional, telenovela e séries. In: Associação Nacional dos Programas de Pós-Graduação em Comunicação. XXVIII Encontro Anual da Compós. Porto Alegre: 2019.

HARTLEY, J. Comunicação, Estudos Culturais e Media: Conceitos-Chave. Lisboa: Quimera, 2004.

HIGHFIELD, T.; HARRINGTON, S.; BRUNS, A. Twitter as a technology for audiencing and fandom: The\# Eurovision phenomenon. Information, Communication \& Society, v. 16, n. 3, p. 315-339, 2013.

HUERGO, J; MORAWICKI, K. Memória e promessa: conversas com Jesús MartínBarbero. Tradução: Fabrícia Reginato. Porto Alegre: Sulina, 2018.

JACKS, N. et al. (Org.). Meios e audiências II: a consolidação dos estudos de recepção no Brasil. Porto Alegre: Sulina, 2014.

JACKS, N.; ESCOSTEGUY, A. C. Comunicação e Recepção. São Paulo: Hacker Editores, 2005.

JACKS, N.; ESCOSTEGUY, A.C.; RONSINI,V. M. Barbero, para os brasileiros. In: HUERGO,J.; MORAWICKI, K. Memória e promessa: Conversas com Jesús MartínBarbero. Tradução: Fabrícia Reginatto. Porto Alegre: Sulina, 2018.

JACKS, N.; OIKAWA, E.; et al. Passione e Avenida Brasil: produção crossmídia e recepção transmidiática? In: LOPES, M. I. V. (Org.). Estratégias de transmidiação na ficção televisiva brasileira. Porto Alegre: Sulina, 2013.

JACKS, N.; RONSINI, V. M.Telenovela em múltiplas telas: da circulação ao consumo. In: LOPES, M. I. V. (Org.). Ficção televisiva transmidiática no Brasil: plataformas, convergência, comunidades virtuais. Porto Alegre: Sulina, 2011.

JACKS, N.; SCHIMITZ, D.; WOTTRICH, L. Comunicación en Jesús Martín-Barbero: incursión a tres obras fundantes. In: RINCÓN, O. (ed.); JACKS, N.; SCHIMITZ, D.; WOTTRICH, L. (orgs.) Un nuevo mapa para investigar la mutación cultural. Diálogo con la propuesta de Jesús Martín-Barbero. Tradução: Fabrícia Reginatto. Quito: CIESPAL, 2019.

JACKS, N.; SIFUENTES, L. Velho Chico: mais um episódio na busca pelo fã de telenovela. In: LOPES, M. I. V. Por uma teoria de fãs da ficção televisiva II: práticas de fãs no ambiente da cultura participativa. Porto Alegre: Sulina, 2017.

JACKS, N.; SIFUENTES, L.; LIBARDI, G. Classe social: elemento estrutural (des)considerado nas pesquisas de recepção e consumo midiático. In: JACKS, N.; PIEDRAS, E.; PIENIZ, M.; JOHN, V. Meios e audiências III- Reconfigurações dos estudos de recepção e consumo midiático no Brasil. Porto Alegre: Sulina, 2017.

JENKINS, H. Cultura da convergência. São Paulo: Aleph, 2009.

JENKINS, H. Cultura da convergência. SãoPaulo: Aleph, 2008. 
JENKINS, H. Fans, Bloggers and Games: Exploring Participatory Culture. Nova Iorque: New York University Press, 2006.

JENKINS, H. Teens, acafandom and beyond: week two, parto ne (Henry Jenkins, Erica Rand, and Karen Hellekson). Confessions of na aca-fan, 20 jun., 2011 Disponível em: http://henryjenkins.org/ Acesso em jan. 2020.

JENKINS, H. Transmedia Storytelling and Entertainment: An annotated syllabus. Journal of Media \& Cultural Studies, 24 (6), p. 943-958. Disponível em: http://dx.doi.org/10.1080/10304312.2010.510599 Acesso em abril de 2018.

JENKINS, H. Transmedia storytelling: moving characters from books to films to video games can make then stronger and more compelling. MIT technology review, 15, jan, 2003. Disponível em: http:/www.technologyreview.com/biotech/13052/ Acesso em maio de 2018.

JENKINS, H.; FORD, S.; GREEN, J. Spreadable media: creating value and meaning in a networked culture. New York: New York University Press, 2013.

JESUS, K. de. A caminho de Westeros: Game of Thrones- a complexidade narrativa na série televisiva e seu desenvolvimento nas demais mídias. 2015. 88f. Dissertação (Mestrado em Comunicação). Universidade Anhembi Morumbi, São Paulo, 2015.

JOHN, V.M.; RIBEIRO, R.R.; SILVA, G.H. da. Sensorialidad: la mediación que siempre estuvo presente. In: RINCÓN, O. (ed.); JACKS, N.; SCHIMITZ, D.; WOTTRICH, L. (orgs.) Un nuevo mapa para investigar la mutación cultural. Diálogo con la propuesta de Jesús Martín-Barbero. Tradução: Fabrícia Reginatto. Quito: CIESPAL, 2019.

JOST, F. Novos Comportamentos para Antigas Mídias ou Antigos Comportamentos para Novas Mídias? Matrizes. São Paulo, ECA-USP, Ano 4, n. 2, jan.-jul., p. 110$125,2011$.

JUNIOR, C. P. Segunda tela: uma abordagem sobre narrativas. In: SIMPÓSIO NACIONAL ABCIBER, VIII, 2014. São Paulo. Anais... ABCiber: São Paulo, p.114, 2014.

KIM, S. Rereading David Morley's The 'Nationwide' Audience. Cultural Studies 18 (1), p. 84-108, 2004.

KINDER, M. Playing with power in movies, television and videogames. From Muppet Babies to Teenage Mutant Ninja Turtles. Berkley, LA: University of California Press, 1991.

LACALLE, C. As novas narrativas da ficção televisiva e a Internet. Matrizes, 3 (2), pp.79-102, 2010.

LACALLE, C. Género y edad en la recepción de la ficción televisiva. Comunicar, 39 (20), p.111-118, 2012.

LAPLANTINE, F. A Descrição Etnográfica. São Paulo: Terceira Margem, 2004. 
LASICA, J. D. Darknet: hollywood's war against the digital generation. New Jersey: John Wiley \& Sons, 2005.

LAVERDE TOSCANO, M. C.; ARANGUREN DÍAZ, F. Los mapas diurnos y nocturnos de Jesús Martín-Barbero. Nómadas. Bogotá: Universidad Central, n. 7, p. 145-169, set. $1997 . \quad$ Disponível em: https $/ /$ www.redalyc.org/pdf/1051/105118909012.pdf Acesso em outubro de 2019.

LEAL, O. F. A leitura social da novela das oito. Petrópolis: Ed. Vozes, 1986.

LÉVY, P. Cibercultura. Lisboa: Instituto Piaget 1999.

LÉVY, P. Cibercultura. Lisboa: Instituto Piaget, 1997.

LÉVY, P. O Que é Virtual?. Rio: Editora 34, 1996.

LINDLOF, T. R.; TAYLOR, B. C. Qualitative Communication Research Methods. 3. ed. Thousand Oaks: Sage, 2011.

LIVINGSTONE, S. Internet, children and youth. In: CONSALVO, M.; ESS, C. (Eds.) The handbook of Internet Studies. Oxford: Blackwell, 2011.

LOPES e KUNSCH et al. Editorial. Matrizes, v. 12, n. 1, p. 7-8, jan./abr., 2018.

LOPES, M. I. V. ; ROMANCINI, R. Epistemologia da Comunicação. In: CITELLI, A.; BERGER, C.; BACCEGA, M. A.; LOPES, M. I. V.; FRANÇA, V. V. (org.). Dicionário de Comunicação: escolas, teorias e autores. São Paulo: Editora Contexto, 2014.

LOPES, M. I. V. et. al. Transmediação, plataformas múltiplas, colaboratividade e criatividade na ficção televisiva brasileira. In: LOPES, M. I. V. (Org.) Ficção televisiva no Brasil: temas e perspectivas. São Paulo: Globo, 2009.

LOPES, M. I. V. Pesquisa em Comunicação. 12 ed. São Paulo: Loyola, 2014.

LOPES, M. I. V. Pesquisa em Comunicação: Questões epistemológicas, teóricas e metodológicas. In: Revista Brasileira de Ciências da Comunicação, v. XXVII, n. 1, jan/jun 2004.

LOPES, M. I. V. Reflexividade e relacionismo como questões epistemológicas na pesquisa empírica em Comunicação. In: BRAGA, J.L.; LOPES, M.I.V.; MARTINO,L.C. (orgs.). Pesquisa empírica em comunicação. São Paulo: Paulus, 2010b.

LOPES, M. I. V.; BORELLI, S. H. S.; RESENDE, V. Vivendo com a telenovela: mediações, recepção e teleficcionalidade. São Paulo: Summus, 2002.

LOPES, M. I. V.; GÓMEZ-OROZCO, G. (Orgs.) Memória social e ficção televisiva nos países ibero-americanos: Anuário Obitel 2013. Porto Alegre: Sulina, 2013.

LOPES, M. I. V.; MUNGIOLI, C. "Nova classe média" e as redes sociais potencializam a ficção televisiva. In: LOPES, M. I. V.; GÓMEZ-OROZCO, G. (Orgs.) Transnacionalização da ficção televisiva nos países ibero-americanos: Anuário Obitel 2012. Porto Alegre: Sulina, 2012. 
LOPES, M. I. V.; OROZCO GÓMEZ, G. (Orgs.). Nota metodológica. In: LOPES, M. I. V. de; OROZCO GÓMEZ, G. Estratégias de produção transmídia na ficção televisiva: Anuário Obitel 2014. Porto Alegre: Sulina, 2014b.

LOPES, M. I. V.; OROZCO GÓMEZ, G. (Orgs.). Relações de gênero na fícção televisiva: Anuário Obitel 2015. Porto Alegre: Sulina, 2015.

LOPES, M. I.V. A teoria barberiana da comunicação. Matrizes, v. 12, n. 1, p. 39-63, jan./abr., 2018.

LOPES, M. I.V.; LEMOS, L. et al. A construção de mundos na telenovela brasileira: um estudo de caso a partir das cinco personagens mais lembradas. In: LOPES, M.I.V. (org.) A construção de mundos na ficção televisiva brasileira. Porto Alegre: Sulina, 2019b.

LOPES, M. I.V.; LEMOS, L. et al. Brasil: streaming, tudo junto e misturado. In: LOPES, M.I.V.; OROZCO GÓMEZ, G. (coords.) Modelos de Distribuiçãa da Televisão por Internet: Atores, Tecnologias, Estratégias: Anuário Obitel 2019. Porto Alegre: Sulina, 2019.

LOPES, M.I.V. Telenovela brasileira: uma narrativa sobre a nação. Revista Comunicação \& Educação, n.26, p. 17-34, jan./abr. 2003.

LOPES, M.I.V. Telenovela como recurso comunicativo. Matrizes, v. 3, n. 1, p. 21-47, ago./dez., 2009.

LOPES, M.I.V. Uma agenda metodológica presente para análise de recepção na América Latina. In: JACKS, N. (coord/ ed.). Analisis de recepción en América Latina: um recuento histórico com perspectivas al futuro. Quito: CIESPAL, 2010.

LOPES, M.I.V.; GRECO, C. et al. Brasil: a "TV transformada" na ficção televisiva brasileira. In: LOPES, M.I.V.; OROZCO GÓMEZ, G. (coords.) (Re)invenção de gêneros e formatos da ficção televisiva: Anuário Obitel 2016. Porto Alegre: Sulina, 2016.

LOPES, M.I.V.; GRECO, C. et al. Brasil: dinâmicas da ficção televisiva na transição multicanal. In: LOPES, M.I.V.; OROZCO GÓMEZ, G. (coords.) Ficção Televisiva Iber-Americana em Plataformas de Video on Demand: Anuário Obitel 2018. Porto Alegre: Sulina, 2018.

LOPES, M.I.V.; GRECO, C. et al. Brasil: rumo à produção e recepção $360^{\circ}$. In: LOPES, M.I.V.; OROZCO GÓMEZ, G. (coords.) Uma década de Ficção Televisiva na Ibero-América. Uma análise de Dez Anos do Obitel (2007-2016): Anuário Obitel 2017. Porto Alegre: Sulina, 2017.

LOPES, M.I.V.; MUNGIOLI,C. et al. Brasil: a telenovela como fenômeno midiático. In: LOPES, M.I.V.; OROZCO GÓMEZ, G. (coords.) Memória social e ficção televisiva em países ibero-americanos: Anuário Obitel 2013. Porto Alegre: Sulina, 2013. 
LOPES, M.I.V.; MUNGIOLI,C. et al. Brasil: Caminhos da ficção entre velhos e novos meios. In: LOPES e OROZCO GÓMEZ, G. (coods.) Qualidade na ficção televisiva e participação transmidiática das audiências: Anuário Obitel 2011. Porto Alegre, 2011.

LOPES, M.I.V.; MUNGIOLI,C. et al. Brasil: trânsito de formas e conteúdos na ficção televisiva. In: LOPES, M. I. V.; OROZCO GÓMEZ, G. (Orgs.). Estratégias de produção transmídia na ficção televisiva: Anuário Obitel 2014. Porto Alegre: Sulina, 2014.

LOYOLA, M.A. Apresentação. Pierre Bourdieu entrevistado por Maria Andréa Loyola. Rio de Janeiro: EdUERJ, 2002.

MALMGREN, C. D. Anatomy of murder: mystery, detective and crime fiction. Bowling Green: Popular Press, 2001.

MARCONDES FILHO, C. Televisão: a vida pelo vídeo. São Paulo: Moderna, 1988.

MARQUES, M. P.; SAMULSKI, D. M. Análise da carreira esportiva de jovens atletas de futebol na transição da fase amadora para a fase profissional: escolaridade, iniciação, contexto sociofamiliar e planejamento da carreira. Revista Brasileira de Educação Física e Esporte, v.23, n.2, p.103-19, abr./jun. 2009.

MARROQUÍN, A. La palabra habitada. Andamiajes del pensamiento de MartínBarbero. In: J. Martin-Barbero: La palabra y la acción. Por una dialéctica de la liberación. Bogotá. Editorial Pontificia Universidad Javeriana, 2018.

MARROQUÍN, A. Sobre el inmenso oficio de cartografiar y otras herencias asombrosas de Jesús Martín-Barbero. Prólogo. In: RINCÓN, O. (ed.); JACKS, N.; SCHIMITZ, D.; WOTTRICH, L. (orgs.). Un nuevo mapa para investigar la mutación cultural. Diálogo con la propuesta de Jesús Martín-Barbero. Tradução: Fabrícia Reginatto. Quito: CIESPAL, 2019.

MARTÍN- BARBERO, J. De los medios a las mediaciones: comunicación, cultura y hegemonía. Barcelona: Anthropos, 2010.

MARTÍN- SERRANO, M. La mediación social. Madri: Akal, 1977.

MARTIN, C. The third screen: marketing to your customers in a world gone mobile. Nicholas Brealey: Boston, MA, 2011.

MARTÍN-BARBERO, J . Diversidade em convergência. Matrizes, v.8, n.2, pp.15-33, jul./dez, 2014.

MARTÍN-BARBERO, J . La pertinencia en el horizonte de las nuevas tecnologias y de la sociedad de la comunicación. In: Hoppenhayn, M., \& Sojo A. (Orgs.). Sentidos de pertenencia en sociedades fragmentadas: América Latina en una perspectiva global. Buenos Aires: Siglo XXI, 2011.

MARTÍN-BARBERO, J. Introdução. Televisión y melodrama. Géneros y lecturas de la televisión en Colombia. Edição em coordenação com Sonia Muñoz. Bogotá: Tercer Mundo, 1992. 
http:/pdfhumanidades.com/sites/default/files/apuntes/25\%20-

\%20martin\%20barbero\%20Television\%20y\%20melodrama.pdf Acesso jutho 2019.

MARTÍN-BARBERO, J. América Latina e os anos recentes: o estudo da recepção em comunicação social. In: Souza, Mauro Wilton de (Org.). Sujeito, o lado oculto do receptor. São Paulo: Brasiliense, 2002.

MARTÍN-BARBERO, J. Comunicación fin de siglo. ¿Para donde vá nuestra investigación? Madrid: Telos, 47, 1996.

MARTÍN-BARBERO, J. De los medios a las mediaciones- comunicación, cultura y hegemonía. Barcelona: Gustavo Gili, 1987.

MARTÍN-BARBERO, J. Dos meios às mediações. Comunicação, cultura e hegemonia. 2. Ed. Rio de Janeiro: Editora UFRJ, 2003 b.

MARTÍN-BARBERO, J. Dos meios às mediações. Comunicação, cultura e hegemonia. Tradução Ronald Polito e Sérgio Alcides. 6 ${ }^{\mathrm{a}}$ ed. Rio de Janeiro: Editora UFRJ, 2009b.

MARTÍN-BARBERO, J. Dos meios às mediações: comunicação, cultura e hegemonia. Rio de Janeiro: Editora da UFRJ, 1997.

MARTÍN-BARBERO, J. Entrevista. In: HUERGO, J; MORAWICKI, K. Memória e promessa: conversas com Jesús Martín-Barbero. Tradução: Fabrícia Reginato. Porto Alegre: Sulina, 2018.

MARTÍN-BARBERO, J. Jóvenes. Entre el palimpsesto y el hipertexto. Barcelona: NED Ediciones, 2017b.

MARTÍN-BARBERO, J. Oficio de Cartógrafo Travessias latino-americanas da comunicação na cultura. Tradução: Fidelina Gonzáles. Coleção Comunicação Contemporânea 3, São Paulo: Edições Loyola, 2004.

MARTÍN-BARBERO, J. Pistas para entre- ver meios e mediações. Prefácio à $\mathbf{2}^{\mathbf{a}}$ edição de Dos meios às mediações: comunicação, cultura e hegemonia. Tradução de Maria Immacolata Vassallo de Lopes. Rio de Janeiro: Ed. UFRJ, p. 11-21, 2003.

MARTÍN-BARBERO, J. Uma aventura epistemológica - entrevistado por Maria Immacolata Vassalo de Lopes. Matrizes, v. 2, n. 2, 2009.

MARTÍN-BARBERO, J.; CORONA BERKIN, S. Ver com los otros: comunicación intercultural. Ciudad de México: Fondo de Cultura Económica, 2017.

MARTÍN-BARBERO, J.; REY, G. Os exercícios do ver: hegemonia audiovisual e fiç̧ão televisiva. $2^{a}$. ed. São Paulo: Ed. SENAC, 2004.

MARTÍN-BARBERO, Jésus. Prefácio. In: LOPES, M. I. V.; BORELLI, S. H. S.; RESENDE, V. Vivendo com a telenovela: mediações, recepção, teleficcionalidade. São Paulo: Summus, 2002b.

MARTÍN-BARBERO, Jesús. Tecnicidades, identidades, alteridades: mudanças e opacidades da comunicação no novo século. In: MORAES, Denis. (Org.). Sociedade midiatizada. Rio de Janeiro: Mauad, 2006. 
MARX, K. Miséria da Filosofia. São Paulo: Expressão Popular, 2009 [1847].

MARX, K.; ENGELS, F. A Ideologia Alemã: São Paulo: Boitempo, 2007 [1845- 46].

MASSAROLO, J. C.; MESQUITA, D. Reflexões teóricas e metodológicas sobre narrativas transmídia. In: COMPÓS, XXIII, 2014, Belém. Anais... Belém, p. 1-17, 2014.

MATOS, J.C.O. Telenovela, comunidade de recepção e ambientes de sociabilidade online: luto e sentimento de perda como elementos de evidência e fortalecimento de laços sociais na experiência televisiva. 2017. Tese. 186f. (Doutorado em Comunicação e Cultura Contemporâneas). Universidade Federal da Bahia, Salvador, 2017.

MATTELART, A.; MATTELART, M. O carnaval das imagens. São Paulo: Brasiliense, 1989.

MATTOS, S. História da Televisão Brasileira: uma visão econômica, social e política. $5^{\mathrm{a}}$. ed. Petrópolis: Vozes, 2010.

MCQUAIL, D. Teoria da comunicação de massas. Lisboa: Fundação Calouste Gulbenkian, 2003.

MEDHURST, A. If Anywhere: Class Identifications and Cultural Studies Academics. In: MUNT, S. Cultural studies and the working class. London: Routledge, 2000. p. 1935

MILIBAND, R. Análise de classes. In: GIDDENS, A.; TURNER, J. (Orgs.) Teoria Social Hoje. Tradução: Gilson César Cardoso de Sousa. São Paulo: Editora UNESP, 1999.

MILLS, C. W. White Collar. New York: Oxford University Press, 1951.

MITTELL, J. Complex $\boldsymbol{T V}$ : the poetics of contemporary television storytelling. Nova Iorque, Londres. Editora: New York University Press, 2015.

MITTELL, J. Narrative complexity in contemporany American television. The Velvet Light Trap. University of Texas Press, 58 (1), 29-40. 2006. Disponível em: http://juliaeckel.de/seminare/docs/mittell\%20narrative\%20complexity.pdf. Acesso em setembro 2019.

MORIN, E. Introdução ao pensamento complexo. Tradução Eliane Lisboa. 5.ed. Porto Alegre: Sulina, 2015.

MORLEY, D. Televisión, audiencias y estudios culturales. Buenos Aires: Amorrortu, 1996.

MORLEY, D. The Nationwide audience. London: British Film Institute, 1980.

MORLEY, D.; SILVERSTONE, R. Communication and context: ethnographic perspectives on the media audience. In: JENSEN, K. B. ; JANKOWSKI, N. (eds). A Hanbook of Qualitative Methodologies for Mass Communication Research. London: Routledge, 1991. 
MÜLLER, E. Where quality matters: discourses on the art of making a youtube video In: VONDERAU, P.; P. SNICKARS, ed(s). The Youtube Reader. National library of Sweden, 2009.

MUNT, S. Introduction. In: MUNT, Sally. Cultural Studies and the working class. London: Cassel, 2000. p. 1-16

MURDOCK, G. Comunicação contemporânea e questões de classe. Matrizes, ano 2, n. 2, p. 31-56, 2009.

MURDOCK, G.; MCCRON, R. Consciousness of class and consciousness of generation. In: HALL, S. ; JEFFERSON, T. Resistance Through Rituals: Youth subcultures in post-war Britain. Birmingham: Taylor \& Francis e-Library, 2003.

MURRAY, J. Hamlet on the Holodeck - The future of narrative in cyberspace. Cambridge: The MIT Press, 1997.

NÉIA, L. Velho Chico, Complexidade Tropicalista. In: Intercom - Sociedade Brasileira de Estudos Interdisciplinares da Comunicação. XXXIX Congresso Brasileiro de Ciências da Comunicação: São Paulo, 2016.

NERI, M. C. (coord). A Nova Classe Média. Rio de Janeiro: FGV/IBRE, CPS, 2008. Disponível em: <http://www3.fgv.br/ibrecps/M3/M3_ ANovaClasseMedia_Port_2.pdf> Acesso em junho de 2019.

NERI, M. C. A nova classe média. Rio de Janeiro: FGV, 2008.

NERI, M. C. A nova classe média: o lado brilhante da base da pirâmide. São Paulo: Saraiva, 2012.

NERI, M. C. A nova classe média: o lado brilhante dos pobres. Rio de Janeiro: FGV, 2010.

OIKAWA, E.; JOHN, V.; AVANCINI, D. De @ berilopassione a \#MeServeVadia: Passione e Avenida Brasil no contexto de convergência midiática. Ciberlegenda, n. 27, p. 106-118, 2012.

OLIVEIRA-CRUZ, M.F.de. Dona de casa e da própria vida? Leituras sobre o trabalho feminino na publicidade por mulheres da nova classe trabalhadora. $328 \mathrm{f}$. Tese (Doutorado em Comunicação Midiática). Universidade Federal de Santa Maria. Santa Maria, 2016.

OROZCO GÓMEZ, G. La condición comunicacional contemporánea. Desafíos latinoamericanos de La investigación de las interacciones en la sociedad red. In: JACKS, N. et. al (Orgs.). Análisis de recepción en América Latina: un recuento histórico con perspectivas al futuro. Quito-Ecuador: CIESPAL, p. 377-408, 2011.

OROZCO, G.; GONZÁLEZ, R. Uma cortada metodológica. Abordajes cualitativos en la investigación em comunicación, médios y audiências. México: Productora de Contenidos Culturales, 2011.

ORTIZ, R. Pierre Bourdieu. São Paulo: Ática, 1983. 
ORTIZ, R.; BORELLI, S. H. S.; RAMOS, J. M. O. Telenovela história e produção. $1^{\mathrm{a}}$ ed. São Paulo: Brasiliense, 1989.

PALLOTTINI, R. Dramaturgia de televisão. São Paulo: Moderna, 1998.

PEARSON, R. Reading Lost: Perspectives on a Hit Television Show. London: I. B. Tauris, 2009.

PEREIRA, T. N. Da felicidade à alegria: os usos e as apropriações do telejomal Jornal Nacional por famílias de classe popular. 195f. Dissertação (Mestrado em Comunicação Midiática). Universidade Federal de Santa Maria. Santa Maria, 2015.

PEREIRA, T. N. Sobre como ver com os outros em uma era globalizada e intercultural. Matrizes, v. 12, n. 1, p. 205- 209, jan./abr., 2018.

PIENIZ, M. Tecnicidade como mediação empírica: a reconfiguração da recepção de telenovela a partir do Twitter. 2013. 198f. Tese (Doutorado em Comunicação e Informação). Universidade Federal do Rio Grande do Sul, Porto Alegre, 2013.

POCHMANN, M. Nova Classe Média? - O trabalho na base da pirâmide social brasileira. São Paulo: Boitempo, 2012.

POCHMANN, M. O Mito da Grande Classe Média: capitalismo e estrutura social. São Paulo: Boitempo, 2014.

POTTS, J. D. et. al. Social network markets: a new definition of the creative industries. Journal of Cultural Economics, v. 32, n. 3, p. 166-185, 2008.

POUPART, J. et al. A pesquisa qualitativa. Enfoques epistemológicos e metodológicos. Petrópolis: Vozes, 2008.

PRIMO, A. Interações em rede. Porto Alegre: Sulina, 2013.

PRIORE, M. DEL. Histórias da gente brasileira. Volume 4: República- Testemunhos (1951-2000). São Paulo: LeYa, 2019.

QUADROS, W. J. de; GIMENEZ, D. M.; ANTUNES, D. J. N. Afinal, somos um país de classe média? Mercado de trabalho, renda e transformações sociais no Brasil dos anos 2000. In: BARTELT, D. D. (Org.). A "nova classe média" no Brasil como conceito e projeto político. Rio de Janeiro: Fundação Heinrich Böll, 2013.

QUADROS, W.; MAIA, A. Estrutura Sócio-ocupacional no Brasil. R. Econ. Contemp. Rio de Janeiro, v. 14, n. 3, p. 443-468, set/dez, 2010.

REGO, W.L.; PINZANI, A. Vozes do Bolsa Família: autonomia, dinheiro e cidadania. São Paulo: Editora Unesp, 2013.

REIS, C.; LOPES, A. C. M. Dicionário de Narratologia. Coimbra: Almedina, 2007.

RINCÓN, O. Mi invención sobre el mapa para comprender el sensorium de la contemporaneidad. Epílogo. In: RINCÓN, O. (ed.); JACKS, N.; SCHIMITZ, D.; WOTTRICH, L. (orgs.). Un nuevo mapa para investigar la mutación cultural. Diálogo con la propuesta de Jesús Martín-Barbero. Tradução: Fabrícia Reginatto. Quito: CIESPAL, 2019. 
RINCÓN, O. Mutações bastardas da comunicação. Matrizes, v. 12, n. 1, p. 65-78, jan./abr., 2018.

ROCHA, S.; ROCHE, F. L. Temporalidades: para pensar la contemporaneidad de lo no-contemporáneo. In: RINCÓN, O. (ed.); JACKS, N.; SCHIMITZ, D.; WOTTRICH, L. (orgs.). Un nuevo mapa para investigar la mutación cultural. Diálogo con la propuesta de Jesús Martín-Barbero. Tradução: Fabrícia Reginatto. Quito: CIESPAL, 2019.

RONSINI, V. M. A crença no mérito e a desigualdade: a recepção da telenovela do horário nobre. Porto Alegre: Sulina, 2012.

RONSINI, V. M. A perspectiva das mediações de Jesús Martín-Barbero (ou como sujar as mãos na cozinha da pesquisa empírica de recepção). In: XIX Encontro da Compós. Rio de Janeiro, 2010.

RONSINI, V. M. A perspectiva das mediações de Jesús Martín-Barbero (ou como sujar as mãos na cozinha da pesquisa empírica de recepção). In: GOMES, I; JANOTTI JUNIOR, J. Comunicação e estudos culturais. Salvador: EDUFBA, 2011

RONSINI, V. M. Apontamentos sobre classe social em um estudo de recepção. In: FREIRE FILHO, J; BORGES, G. (Orgs.). Estudos de Televisão. Diálogos Brasil Portugal. Porto Alegre: Sulina, 2011b.

RONSINI, V. M. e BRIGNOL, L. Distinção e comunicação na apropriação da moda pelos fãs de telenovelas. In: LOPES, M. I. V. Por uma teoria de fãs da ficção televisiva II: práticas de fãs no ambiente da cultura participativa. Porto Alegre: Sulina, 2017.

RONSINI, V. M. Mercadores de sentido: consumo de mídia e identidades juvenis. Porto Alegre: Sulina, 2007.

RONSINI, V. M. Mídia, cultura e classe: a ordem da diferença. Trabalho apresentado ao Grupo de Trabalho Mídia e Recepção. XVI Encontro da Compós, na UTP, Curitiba (PR), junho de 2007b.

RONSINI, V. M.; SILVA, R.; WOTTRICH, L. A perspectiva das mediações de Jesús Martín- Barbero no Estudo de Recepção de Telenovela. In: Anais do XXXII Congresso Brasileiro de Ciência da Comunicação (Nacional) - Comunicação, educação e cultura na era digital. Curitiba/PR, 2009.

SACRAMENTO, I. A carnavalização na teledramaturgia de Dias Gomes: a presença do realismo grotesco na modernização da telenovela. Intercom - Revista Brasileira de Ciências da Comunicação, v.37, n.1, p. 155-174, jan./jun., 2014. Disponível em: http://www.scielo.br/pdf/interc/v37n1/a08v37n1.pdf Acesso janeiro de 2019.

SALATA, A. R. Quem é Classe Média no Brasil? Um Estudo sobre Identidades de Classe. Dados - Revista de Ciências Sociais, v. 58, n. 1, enero-marzo, 2015, p. 111149. Universidade do Estado do Rio de Janeiro, Rio de Janeiro. 
SANTOS, J.A.F. Estrutura de posições de classe no Brasil- mapeamento, mudanças e efeito na renda. Belo Horizonte: UFMG; Rio de Janeiro: IUPERJ, 2002.

SARTI, C. A. A família como espelho: um estudo sobre a moral dos pobres. Campinas: Autores Associados, 1996.

SCALON, C.; SALATA, A. Uma Nova Classe Média no Brasil da Última Década? O debate a partir da perspectiva sociológica. Revista Sociedade e Estado. v. 27 n. 2, maio/agosto 2012. Disponível em: http:/www.scielo.br/pdf/se/v27n2/a09v27n2.pdf Acesso outubro de 2018.

SCOLARI, C. A. Narrativas Transmedia: Cuando todos los medios cuentan. Deusto, 2013.

SCOLARI, C. A. Narrativas Transmídia: consumidores implícitos, mundos narrativos e branding na produção de mídia contemporânea. Parágrafo. jan./jun.2015 v. 1, n. 3, p. 7-19, 2015 Disponível em: http://revistaseletronicas.fiamfaam.br/index.php/recicofi/article/view/291 Acesso em março de 2018.

SCOLARI, C. A. Transmedia Storytelling: Implicit Consumers, Narrative Worlds, and Branding in Contemporary Media Production. International Journal of $\begin{array}{lllll}\text { Communication } & 3, & 586-606, & & \end{array}$ https//ijoc.org/index.php/ijoc/article/view/477/336 Acesso em abril de 2018.

SIFUENTES, L. "Todo mundo fala mal, mas todo mundo vê": estudo comparativo do consumo de telenovela por mulheres de diferentes classes. 2014. 299f. Tese (Doutorado em Comunicação). Pontifícia Universidade Católica do Rio Grande do Sul. Porto Alegre, 2014.

SIFUENTES, L. Telenovela e a identidade feminina de jovens de classe popular. 2010. 238f. Dissertação (Mestrado em Comunicação Midiática). Universidade Federal de Santa Maria, Santa Maria, 2010.

SIFUENTES, L.; VILELA, M. D.; JEFFMAN, T. M. O dia em que a internet congelou: apropriações de Avenida Brasil nas mídias sociais. Sessões do Imaginário, v. 17, n. 27 , p. 11-21, 2012.

SIFUENTES, L.; ZANINI, M.C.C. Las identidades en el contexto de las mutaciones tecnológicas. In: RINCÓN, O. (ed.); JACKS, N.; SCHIMITZ, D.; WOTTRICH, L. (orgs.). Un nuevo mapa para investigar la mutación cultural. Diálogo con la propuesta de Jesús Martín-Barbero. Tradução: Fabrícia Reginatto. Quito: CIESPAL, 2019.

SILVA, E. H.; ANDRADE, R. M. B. Sociabilidades midiáticas: flexibilidade, mutação e pluralidade. Comunicação, Mídia e Consumo, v. 6, n. 3, p. 139-157, 2006.

SILVA, L.A.P.; BASEIO, M.A.F. Narrativa $(s)$ como estratégia $(s)$ de comunicabilidade. In: RINCÓN, O. (ed.); JACKS, N.; SCHIMITZ, D.; WOTTRICH, L. 
(orgs.). Un nuevo mapa para investigar la mutación cultural. Diálogo con la propuesta de Jesús Martín-Barbero. Tradução: Fabrícia Reginatto. Quito: CIESPAL, 2019.

SILVERSTONE, R. Television and Everyday life. London: Routledge, 1994.

SKEGGS, B. Class, self and culture. London: Routledge, 2004.

SKEGGS, B. Classifying Practices: Representations, Capitals and Recognitions. In: MAHONY, Pat; ZMROCZEK, Christine (Ed.). Class matters. Working-class Women's perspectives on Social Class. London: Taylor \& Francis, 1997. p. 127-142

SODRÉ, M. A máquina de Narciso. Rio de Janeiro: Cortez, 1984.

SODRÉ, M. Comunicação: um campo em apuros teóricos. Matrizes. v. 5, n. 2, jan/jun. p. 11-27, 2012.

SODRÉ, M. O monopólio da fala: função e linguagem da televisão no Brasil. $7^{\mathrm{a}}$. ed. Petrópolis: Vozes, 2001.

SOUZA, J. (Org.). A invisibilidade da desigualdade brasileira. Belo Horizonte: Editora UFMG, 2006.

SOUZA, J. A classe média no espelho: sua história, seus sonhos e ilusões, sua realidade. Rio de Janeiro: Estação Brasil, 2018.

SOUZA, J. A construção social da subcidadania. Para uma sociologia política da modernidade periférica. 2a . ed. Belo Horizonte: Editora UFMG, 2012.

SOUZA, J. A insivibilidade da luta de classes ou a cegueira do economicismo. In: BARTELT, D. D. (Org.). A "nova classe média" no Brasil como conceito e projeto político. Rio de Janeiro: Fundação Heinrich Böll, 2013.

SOUZA, J. A ralé brasileira- Quem é e como vive. Belo Horizonte: Editora UFMG, 2011.

SOUZA, J. Doença Social. Entrevista concedida ao Jornal Estado de Minas.

Caderno Pensar - Estado de Minas. Belo Horizonte, 15 jan. 2011b, p. 1

SOUZA, J. Os Batalhadores brasileiros. Nova classe média ou nova classe trabalhadora. Belo Horizonte: Editora UFMG, 2010.

SOUZA, M. C. J. Amados amantes narrados nas fanfictions de telenovelas brasileiras. In: LOPES, M. I. V. In: LOPES, M.I.V. (org.) A construção de mundos na ficção televisiva brasileira. Porto Alegre: Sulina, 2019.

SPIELMANN, E. Nosotros habíamos hecho estudios culturales mucho antes de que esta etiqueta apareciera. Entrevista con Jesús Martín-Barbero. Berlin: Dissens,1996.

SPIGEL, L. MANN, D. (orgs.). Private Screenings. Minneapolis: University of Minneapolis, 1992.

STRAUBHAAR, J. D. World television: from global to local. Los Angeles: Sage, 2007. 
THIOLLENT, M. Crítica metodológica, investigação social e enquete operária. São Paulo: Polis, 1980.

TOFFOLETTI, K. Gossip girls in a transmedia world: the sexual and technological anxieties of integral reality. Papers: explorations into children's literature, 18(2), p. 71-77, 2009.

TROTTA, F.; ROXO, M. O gosto musical do Neymar: pagode, funk, sertanejo e o imaginário do popular bem sucedido. Revista Ecopós, v. 17, n. 3, p. 1-12, 2014.

TUFTE, T. Televisão, modernidade e vida quotidiana: discussão sobre o trabalho de Roger Silverstone face a diferentes contextos cult. Intexto, Porto Alegre: UFRGS, v. 2, n. $2, \quad$ p. 1-24, julh./dez., $1997 . \quad$ Disponível em: https $/ /$ www.seer.ufrgs.br/intexto/article/view/3366/3950 Acesso em janeiro de 2020.

TURNER, G. Prefácio à edição brasileira. Prefácio. In: WILLIAMS, R. Televisão: tecnologia e forma cultural. Tradução Marcio Serelle; Mário F. I. Viggiano. 1a . ed. São Paulo: Boitempo; Belo Horizonte, MG: PUCMinas, 2016.

VILCHES, L. A migração digital. São Paulo: Edições Loyola, 2003.

VOORVELD, H. A. M.,; VAN DER GOOT, M. Age differences in media multitasking: A diary study. Journal of Broadcasting \& Electronic Media, 57(3), p. 392-408, 2013.

WILLIAMS, R. Marxismo e literatura. Rio de Janeiro: Zahar Editores, 1979.

WILLIAMS, R. Televisão: tecnologia e forma cultural. Tradução Marcio Serelle; Mário F. I. Viggiano. 1 1 . ed. São Paulo: Boitempo; Belo Horizonte, MG: PUCMinas, 2016.

WRIGHT, E. O. Class counts. Comparative studies in class analysis. Cambridge: Cambridge University Press, 1997.

ZALUAR, A. A máquina e a revolta: as organizações populares e o significado da pobreza. $2^{a}$ ed. São Paulo: Brasiliense, 2000.

\section{Outros materiais consultados}

DUARTE-PLON, L. O super sociólogo. Revista Cult, São Paulo, mai. 2012. Nº 166, p. $20-47$.

HISTÓRIA DO GRUPO GLOBO. Disponível em: https $/ /$ robertomarinho.globo.com/hgg/ Acesso em maio de 2018.

NILSON XAVIER. Disponível em: http://teledramaturgia.com.br/

GSHOW Disponível em: www.globo.com/gshow Acesso em junho de 2019. 


\section{ANEXOS \\ ANEXO A: Clipping com notícias e conteúdos sobre $O$ Sétimo Guardião}

Os anexos foram separados por assunto para facilitar o acesso da pesquisadora.

\section{Sobre a trama}

https://gshow.globo.com/novelas/o-setimo-guardiao/noticia/o-setimo-guardiao-entenda-a-tramada-proxima-novela-das-9.ghtml

https://gshow.globo.com/novelas/o-setimo-guardiao/resumo/20181126-a-20181202-

6a629b823c7243cea06cd809831a01b8.ghtml

https://gshow.globo.com/novelas/o-setimo-guardiao/noticia/estreia-de-o-setimo-guardiaoescute-o-podcast-e-saiba-tudo-sobre-a-nova-novela-das-9.ghtml

https://gshow.globo.com/novelas/o-setimo-guardiao/noticia/ligacao-misteriosa-entrepersonagens-marca-o-inicio-de-o-setimo-guardiao.ghtml

https://www.otvfoco.com.br/edigio-descobre-segredo-de-valentina-e-tem-morte-brutal-em-osetimo-guardiao/

http://audioglobo.globo.com/gshow/podcast/feed/582/setimo-guardiao

https://gshow.globo.com/novelas/o-setimo-guardiao/noticia/leon-5-motivos-que-mostram-queele-e-mais-do-que-um-gato.ghtml

https://gshow.globo.com/novelas/o-setimo-guardiao/vem-por-ai/noticia/gato-leon-exibe-formahumana-confira-imagem.ghtml

https://oplanetatv.clickgratis.com.br/noticias/bastidores/ligacao-misteriosa-entre-personagensmarca-o-inicio-de-o-setimo-guardiao.html

https://oplanetatv.clickgratis.com.br/noticias/bastidores/o-setimo-guardiao-vai-abordar-umtema-que-preocupa-todo-mundo-fake-news.html

https://nilsonxavier.blogosfera.uol.com.br/2018/11/12/realismo-fantastico-terror-pesadomarcou-a-estreia-de-o-7o-guardiao/

https://mauriciostycer.blogosfera.uol.com.br/2018/11/26/com-cara-de-velha-o-setimo-guardiaobusca-solucionar-crise-das-novelas/

https://nilsonxavier.blogosfera.uol.com.br/2018/11/27/setimo-guardiao-a-vila-que-lilia-cabraltanto-prometeu-ainda-nao-aconteceu/

https://kogut.oglobo.globo.com/noticias-da-tv/novelas/fotos/2018/12/leon-quase-seradescoberto-veja-outras-cenas-marcantes-da-semana-em-o-setimo-guardiao.html

https://gshow.globo.com/novelas/o-setimo-guardiao/noticia/leon-conta-o-que-vai-bombar-nasemana-de-10-a-15-de-dezembro.ghtml

https://mauriciostycer.blogosfera.uol.com.br/2018/12/05/tara-de-delegado-por-calcinha-viramerchan-insolito-em-o-setimo-guardiao/ 
https://nilsonxavier.blogosfera.uol.com.br/

https://noticiasdatv.uol.com.br/noticia/novelas/sexo-com-cunhado-e-pedreiro-avantajado-o-quevai-pegar-em-o-setimo-guardiao--23729

\section{Personagens}

https://gshow.globo.com/novelas/o-setimo-guardiao/noticia/eduardo-moscovis-sera-a-formahumana-do-gato-leon-de-o-setimo-guardiao.ghtml

https://kogut.oglobo.globo.com/noticias-da-tv/novelas/noticia/2018/11/o-setimo-guardiao-saibatudo-sobre-o-passado-de-luz.html

https://gshow.globo.com/novelas/o-setimo-guardiao/noticia/personagem-de-leticia-spillermovimenta-a-web-com-banho-sem-roupa-sob-olhar-de-leon-reveja-a-cena.ghtml

https://gshow.globo.com/novelas/o-setimo-guardiao/noticia/nany-people-celebra-estreia-emnovelas-com-personagem-trans-vai-de-encontro-com-a-liberdade-que-sempre-lutei.ghtml

https://gshow.globo.com/novelas/o-setimo-guardiao/noticia/o-setimo-guardiao-eduardo-speronifala-de-semelhanca-com-bebeto-seu-personagem.ghtml

https://oplanetatv.clickgratis.com.br/noticias/bastidores/a-luz-e-bem-misteriosa-as-vezes-atebem-estranha-adianta-marina-ruy-barbosa.html

https://oplanetatv.clickgratis.com.br/noticias/bastidores/sera-a-minha-grande-vila-diz-liliacabral-sobre-papel-em-o-setimo-guardiao.html

https://oplanetatv.clickgratis.com.br/noticias/bastidores/tony-ramos-comemora-papel-em$\underline{\text { novela-de-aguinaldo-silva.html }}$

https://oplanetatv.clickgratis.com.br/noticias/bastidores/flavia-alessandra-volta-as-novelas-compersonagem-aspirante-a-celebridade.html

https://oplanetatv.clickgratis.com.br/noticias/celebridades/bruno-gagliasso-comemora-parceriacom-lilia-cabral.html

https://oplanetatv.clickgratis.com.br/noticias/bastidores/nao-sou-a-protagonista-absoluta-danovela-diz-dieckmann-sobre-o-7-guardiao.html

https://oplanetatv.clickgratis.com.br/noticias/bastidores/jose-loreto-comenta-triangulo-amorosocom-bruno-gagliasso-e-marina-ruy-barbosa.html

https://oplanetatv.clickgratis.com.br/noticias/bastidores/personagem-de-matheus-abreu-em-osetimo-guardiao-nao-gostara-de-usar-cuecas.html

https://oplanetatv.clickgratis.com.br/noticias/bastidores/o-setimo-guardiao-o-paraiso-deondina.html

https://oplanetatv.clickgratis.com.br/noticias/bastidores/o-setimo-guardiao-a-vila-valentina$\underline{\text { marsalla.html }}$

https://oplanetatv.clickgratis.com.br/noticias/bastidores/conheca-clotilde-a-personagem-deadriana-lessa-em-o-setimo-guardiao.html

https://oplanetatv.clickgratis.com.br/noticias/audiencia-da-tv/ailton-graca-interpreta-um-padreem-o-setimo-guardiao.html 
https://oplanetatv.clickgratis.com.br/noticias/bastidores/paulo-miklos-vivera-jurandir-em-osetimo-guardiao.html

https://oplanetatv.clickgratis.com.br/noticias/bastidores/direcao-muda-o-perfil-da-personagemde-laryssa-ayres-em-o-setimo-guardiao.html

https://oplanetatv.clickgratis.com.br/noticias/bastidores/o-setimo-guardiao-a-beata-mirtes-e-suadefesa-da-moral-e-dos-bons-costumes.html

https://oplanetatv.clickgratis.com.br/noticias/bastidores/o-setimo-guardiao-personagem-depaulo-vilhena-se-envolvera-com-prostituta-gaga.html

https://oplanetatv.clickgratis.com.br/noticias/bastidores/vanessa-giacomo-sera-nora-deelizabeth-savala-em-o-setimo-guardiao.html

https://oplanetatv.clickgratis.com.br/noticias/bastidores/papel-de-leticia-spiller-em-o-setimoguardiao-descobrira-a-fonte-da-juventude.html

https://oplanetatv.clickgratis.com.br/noticias/bastidores/personagem-de-viviane-araujo-seraobrigada-a-abandonar-a-filha-recem-nascida.html

https://oplanetatv.clickgratis.com.br/noticias/bastidores/o-setimo-guardiao-conheca-ospersonagens-de-heitor-martinez-e-isabela-garcia.html

https://oplanetatv.clickgratis.com.br/noticias/bastidores/theodoro-cochrane-sera-adamastor-emo-setimo-guardiao.html

https://oplanetatv.clickgratis.com.br/noticias/bastidores/o-visual-de-carol-duarte-para-o-setimoguardiao.html

https://oplanetatv.clickgratis.com.br/noticias/bastidores/caio-blat-surge-de-visual-novo-para-osetimo-guardiao.html

https://oplanetatv.clickgratis.com.br/noticias/bastidores/o-setimo-guardiao-ana-beatriznogueira-comemora-parceria-com-elizabeth-savalla.html

https://oplanetatv.clickgratis.com.br/noticias/bastidores/o-setimo-guardiao-o-casal-luz-egabriel.html

https://oplanetatv.clickgratis.com.br/noticias/bastidores/marcos-caruso-volta-a-tv-em-o-setimoguardiao.html

https://oplanetatv.clickgratis.com.br/noticias/bastidores/zeze-polessa-e-milu-em-o-setimoguardiao-a-nova-novela-das-nove.html

https://oplanetatv.clickgratis.com.br/noticias/bastidores/o-visual-de-paulo-rocha-para-viver$\underline{\text { medico-em-o-setimo-guardiao.html }}$

https://oplanetatv.clickgratis.com.br/noticias/bastidores/bruna-linzmeyer-caracterizada-para-anovela-o-setimo-guardiao.html

https://oplanetatv.clickgratis.com.br/noticias/bastidores/vila-de-o-setimo-guardiao-tocara-oterror-em-cidade-do-interior.html

https://oplanetatv.clickgratis.com.br/noticias/bastidores/viviane-araujo-defendera-mae-daprotagonista-de-o-setimo-guardiao.html 
https://oplanetatv.clickgratis.com.br/noticias/bastidores/leopoldo-pacheco-sera-um-enigmaticomorador-de-rua-em-o-setimo-guardiao.html

https://oplanetatv.clickgratis.com.br/noticias/bastidores/o-visual-de-dan-stulbach-para-o-setimoguardiao.html

https://oplanetatv.clickgratis.com.br/noticias/bastidores/fernanda-de-freitas-radicaliza-o-visualpara-o-setimo-guardiao.html

https://oplanetatv.clickgratis.com.br/noticias/bastidores/o-setimo-guardiao-milhem-cortazdefendera-delegado-que-possui-tara-por-lingeries.html

https://oplanetatv.clickgratis.com.br/noticias/bastidores/marcelo-serrado-comenta-sobrepersonagem-machista-de-o-setimo-guardiao.html

https://oplanetatv.clickgratis.com.br/noticias/bastidores/o-setimo-guardiao-felipe-hintze-estreiano-horario-nobre-defendendo-um-polic ial.html

https $\mathrm{s} /$ nilsonxavier.blogosfera.uol.com.br/2019/01/22/3a-vez-que-aguinaldo-prometeuma-boa-personagem-a-lilia-cabral-e-nao-cumpre/

https $/ /$ nilsonxavier.blogosfera.uol.com.br/2019/01/18/isabela-garcia-esta-tao-bem-emo-setimo-guardiao-que-da-gosto-de-ver/

https://f5.folha.uol.com.br/televisao/2019/05/setimo-guardiao-acaba-com-menos-realismofantastico-e-ascensao-de-personagens-secundarios.shtml

\section{Bastidores}

https://gshow.globo.com/novelas/o-setimo-guardiao/noticia/fonte-de-serro-azul-fica-dentro-degruta-cenografica-climatizada-confira-detalhes.ghtml

https://gshow.globo.com/novelas/o-setimo-guardiao/noticia/o-setimo-guardiao-cidadecenografica-de-serro-azul-tem-18-mil-metros-quadrados-e-fica-dentro-dos-estudios-globo.ghtml

https://gshow.globo.com/novelas/o-setimo-guardiao/noticia/o-setimo-guardiao-conta-com-izaanavitoria-caetano-veloso-e-rita-lee-em-sua-trilha-sonora-confira.ghtml

https://gshow.globo.com/novelas/o-setimo-guardiao/noticia/atores-de-o-setimo-guardiao-sedivertem-com-os-comentarios-na-web-sobre-a-estreia-da-novela.ghtml

https://gshow.globo.com/novelas/o-setimo-guardiao/noticia/musica-de-abertura-de-o-setimoguardiao-resgata-sucesso-da-decada-de-70.ghtml

https://gshow.globo.com/novelas/o-setimo-guardiao/noticia/estampa-floral-decote-ciganinha-echoker-estao-entre-as-tendencias-de-moda-em-o-setimo-guardiao.ghtml

https://gshow.globo.com/novelas/o-setimo-guardiao/noticia/gato-leon-descubra-como-sao-osbastidores-das-gravacoes-do-misterioso-personagem-de-o-setimo-guardiao.ghtml

https://gshow.globo.com/novelas/o-setimo-guardiao/noticia/gato-leon-descubra-como-sao-osbastidores-das-gravacoes-do-misterioso-personagem-de-o-setimo-guardiao.ghtml

https://oplanetatv.clickgratis.com.br/noticias/bastidores/diretor-artistico-explica-cortes-nosprimeiros-capitulos-de-o-setimo-guardiao.html 
https://gshow.globo.com/novelas/o-setimo-guardiao/playlist/o-setimo-guardiao-confira-videosde-bastidores-da-novela-das-9.ghtml

https://oplanetatv.clickgratis.com.br/noticias/bastidores/eduardo-moscovis-ainda-nao-foiconvocado-para-gravar-o-setimo-guardiao.html

https://oplanetatv.clickgratis.com.br/noticias/bastidores/o-novo-visual-de-nany-people-para-o$\underline{\text { setimo-guardiao.html }}$

https://oplanetatv.clickgratis.com.br/noticias/bastidores/eduardo-moscovis-avisa-quandosurgira-em-o-setimo-guardiao.html

https://oplanetatv.clickgratis.com.br/noticias/bastidores/confira-a-abertura-de-o-setimoguardiao-globo-da-creditos-aos-alunos-de-curso.html

https://oplanetatv.clickgratis.com.br/noticias/bastidores/luana-piovani-lamenta-nao-ter-sidoconfirmada-no-elenco-de-o-setimo-guardiao.html

https://oplanetatv.clickgratis.com.br/noticias/bastidores/o-setimo-guardiao-conheca-o-elenco-ea-musica-tema-de-abertura.html

https://oplanetatv.clickgratis.com.br/noticias/bastidores/conheca-a-musica-tema-de-abertura-deo-setimo-guardiao.html

https://oplanetatv.clickgratis.com.br/noticias/bastidores/o-setimo-guardiao-a-moda-atemporalde-serro-azul.html

https://oplanetatv.clickgratis.com.br/noticias/bastidores/o-setimo-guardiao-lilia-cabralcomemora-parceria-com-aguinaldo-silva.html

https://oplanetatv.clickgratis.com.br/noticias/bastidores/allan-fiterman-sera-o-diretor-geral-de-osetimo-guardiao.html

https://oplanetatv.clickgratis.com.br/noticias/bastidores/autor-publica-fotos-com-bastidores-dasgravacoes-de-o-setimo-guardiao.html

https $/ /$ gshow.globo.com/novelas/o-setimo-guardiao/noticia/milhem-cortaz-repercutecena-de-seu-personagem-so-de-calcinha-se-expor-nunca-e-confortavel-mas-estoumuito-feliz.ghtml

https:/gshow.globo.com/novelas/o-setimo-guardiao/noticia/antonio-calloni-contacomo-foi-gravar-morte-de-egid io-nunca-estou-preparado.ghtml

https//gshow.globo.com/novelas/o-setimo-guardiao/noticia/carol-duarte-fala-como-foigravar-cena-tensa-de-o-setimo-guardiao.ghtml

https:/gshow.globo.com/novelas/o-setimo-guardiao/noticia/com-dois-personagensmarcantes-nas-novelas-carol-duarte-comemora-oportunidades-na-tv.ghtml

https:/gshow.globo.com/novelas/o-setimo-guardiao/noticia/flavia-alessandra-contaque-se-diverte-com-otaviano-costa-ao-ver-cenas-picantes-de-rita-em-o-setimoguardiao.ghtml

https://gshow.globo.com/novelas/o-setimo-guardiao/noticia/theodoro-cochrane-celebrasucesso-aos-40-anos-e-parceria-com-jose-loreto.ghtml 
https://gshow.globo.com/Famosos/noticia/marina-ruy-barbosa-carolina-dieckmanngrazi-massafera-e-mais-famosos- loucos-por-gatos.ghtml

https:/gshow.globo.com/novelas/o-setimo-guardiao/noticia/paulo-vilhena-e-carolduarte-trocam-elogios-e-comentam-romance-de-personagens-em-o-setimoguardiao.ghtml

https $/ /$ gshow.globo.com/novelas/o-setimo-guardiao/noticia/flavia-alessandraenlouquece-web-exibindo-boa-forma.ghtml

https:/gshow.globo.com/novelas/o-setimo-guardiao/noticia/caio-manhente-celebraaprendizado-com-elizabeth-savala-tenho-tido-uma-aula-diariamente.ghtml

https $/ /$ noticiasdatv.uol.com.br/noticia/novelas/ator-de-o-setimo-guardiao-vive-gaypela-terceira-vez-na-tv-nao-me-agride--23553

https//gshow.globo.com/novelas/o-setimo-guardiao/noticia/lilia-cabral-e-tony-ramoscomentam-sequencia-do-ataque-de-valentina-a-olavo-em-o-setimo-guardiao.ghtml

https $/ /$ gshow.globo.com/novelas/o-setimo-guardiao/noticia/confira-os-bastidores-dabriga-de-mirtes-e-stela-em-o-setimo-guardiao.ghtml

https://gshow.globo.com/novelas/o-setimo-guardiao/noticia/nany-people-e-mulhertrans-em-o-setimo-guardiao-um-estranho-no-ninho-com-muita-cor-e-figurinoquente.ghtml

https:/oplanetatv.clickgratis.com.br/noticias/bastidores/eduardo-moscoviscaracterizado-para-o-setimo-guardiao.html

https $/ /$ noticiasdatv.uol.com.br/noticia/novelas/em-crise-o-setimo-guardiao-aceleramata-gato-e-ganha-novo-protagonista-24581

https:/oplanetatv.clickgratis.com.br/noticias/bastidores/conheca-o-novo-personagemde-o-setimo-guard iao.html

https:/oplanetatv.clickgratis.com.br/noticias/bastidores/paulo-betti-deixa-o-setimoguardiao-luiza-tome-ficara-na-novela-ate-o-fim.html

https $/ /$ oplanetatv.clickgratis.com.br/noticias/bastidores/direcao-da-globo-diz-que-autorde-o-setimo-guard lao-ignorou-pesquisas-internas.html

https://tvefamosos.uol.com.br/blog/nilsonxavier/2019/03/01/setimo-guardiao-tem-bastidoresmais-atraentes-que-a-propria-trama-da-novela/

https $/ /$ tvefamosos.uol.com.br/noticias/ooops/2019/03/14/globo-agradece-e-se-desculpacom-elenco-de-o-setimo-guardiao.htm

https://www.bol.uol.com.br/listas/morte-escandalo-e-processo-por-que-setimo-guardiao-enovela-mais-zicada.htm

\section{Repercussão/ Audiência}

https://contigo.uol.com.br/noticias/ultimas/o-setimo-guardiao-detalhe-da-vila-nos-primeiroscapitulos-vira-piada-nas-redes-sociais.phtml 
https://oplanetatv.clickgratis.com.br/noticias/audiencia-da-tv/a-audiencia-da-primeira-semanade-o-setimo-guardiao.html

https://observatoriodatelevisao.bol.uol.com.br/capitulo-da-novela/2018/10/globo-exibeprimeira-chamada-de-o-setimo-guardiao-e-surpreende-o-publico

https://oplanetatv.clickgratis.com.br/noticias/audiencia-da-tv/o-setimo-guardiao-perde-seispontos-de-audiencia-no-feriadao.html

https://oplanetatv.clickgratis.com.br/noticias/audiencia-da-tv/a-audiencia-do-capitulo-de-estreiade-o-setimo-guardiao.html

https://oplanetatv.clickgratis.com.br/blogs/curtas-e-quentes/apos-a-frustracao-com-segundo-solo-que-esperar-de-o-setimo-guardiao.html

https://gshow.globo.com/novelas/o-setimo-guardiao/noticia/memes-do-gato-leon-de-o-setimoguardiao-confira.ghtml

https://www.otvfoco.com.br/o-setimo-guardiao-registra-pior-audiencia-desde-a-estreia-confiraos-consolidados-de-sabado-24-11-18/

https://oplanetatv.clickgratis.com.br/noticias/bastidores/a-media-de-audiencia-ponderada-de-osetimo-guardiao-esta-abaixo-dos-30-pontos.html

https://oplanetatv.clickgratis.com.br/noticias/audiencia-da-tv/sem-futebol-o-setimo-guardiaoperde-publico-as-quartas.html

https://nilsonxavier.blogosfera.uol.com.br/2018/12/13/esta-gostando-do-7o-guardiao-veja-asmelhores-respostas-da-enquete/

https://noticiasdatv.uol.com.br/noticia/audiencias/o-setimo-guardiao-e-o-programa-mais-vistode-quinta-feira-confira-audiencias-24594

https://nilsonxavier.blogosfera.uol.com.br/2019/01/02/novelas-registram-as-piores-audienciasdos-ultimos-anos-em-epoca-de-festas/

https://nilsonxavier.blogosfera.uol.com.br/2018/12/19/em-noite-quente-setimo-guardiao-tem-apior-audiencia-de-uma-terca-feira/

https://nilsonxavier.blogosfera.uol.com.br/2018/12/13/esta-gostando-do-7o-guardiao-veja-asmelhores-respostas-da-enquete/

https://oplanetatv.clickgratis.com.br/noticias/audiencia-da-tv/pnt-o-setimo-guardiao-vai-super$\underline{\text { mal-no-nordeste.html }}$

https://tvefamosos.uol.com.br/blog/nilsonxavier/2019/03/07/dificil-torcer-pelos-personagensde-o-setimo-guardiao-nao-ha-encanto/

https://tvefamosos.uol.com.br/blog/nilsonxavier/2019/02/21/ate-feijao-e-mais-importante-quetony-ramos-em-o-setimo-guardiao/

https://tvefamosos.uol.com.br/blog/nilsonxavier/2019/02/07/o-setimo-guardiao-renderia-umaserie-ou-superserie-nunca-uma-novela/

https://tvefamosos.uol.com.br/blog/nilsonxavier/2019/02/05/ate-quando-as-novelas-seraoremendos-umas-das-outras/ 
https://tvefamosos.uol.com.br/blog/nilsonxavier/2019/02/01/dica-para-o-setimo-guardiaodeslanchar-mirtes-como-vila-da-trama-central/

https://www.otvfoco.com.br/globo-se-desespera-e-tenta-salvar-o-setimo-guardiao-apos-augeda-novela-fracassar/

http://www.observatoriodaimprensa.com.br/televisao/o-setimo-guardiao-uma-novelaesquecivel/

https://observatoriodatv.uol.com.br/noticias/2019/04/assim-como-o-setimo-guardiao-relembrenovelas-com-capitulos-finais-flopados

https://observatoriodatv.uol.com.br/audiencia-da-tv/2019/05/audiencia-o-setimo-guardiao-temsegundo-pior-ultimo-capitulo-da-historia-da-globo-as-21h

https://observatoriodatv.uol.com.br/audiencia-da-tv/2019/05/o-setimo-guardiao-e-a-quartanovela-menos-vista-da-historia-do-horario-nobre-da-globo

https://natelinha.uol.com.br/novelas/2019/05/17/globo-termina-o-setimo-guardiao-como-quartapior-audiencia-da-historia-128709.php

https://www1.folha.uol.com.br/ilustrada/2019/05/o-setimo-guardiao-chamou-mais-atencao-porsurubao-do-que-por-trama.shtml

\section{Autor}

https://gshow.globo.com/novelas/o-setimo-guardiao/playlist/confira-entrevista-de-aguinaldosilva-sobre-ser-autor.ghtml

https://oplanetatv.clickgratis.com.br/noticias/bastidores/conheca-aguinaldo-silva-o-autor-de-osetimo-guardiao.html

https://oplanetatv.clickgratis.com.br/noticias/bastidores/autor-de-o-setimo-guardiao-explica-atecnica-para-atores-se-destacarem.html

https://oplanetatv.clickgratis.com.br/noticias/bastidores/aguinaldo-silva-acredita-que-o-setimoguardiao-sera-a-sua-melhor-novela.html

https://kogut.oglobo.globo.com/noticias-da-tv/novelas/noticia/2020/01/aguinaldo-silva-deixaglobo-apos-mais-de-40-anos-de-emissora.html

\section{Crossover}

https://f5.folha.uol.com.br/televisao/2018/10/o-setimo-guardiao-de-aguinaldo-silva-fara$\underline{\text { referencias-as-ficticias-tubiacanga-e-greenville.shtml }}$

https:/gshow.globo.com/novelas/o-setimo-guardiao/noticia/luiza-tome-revela-que-recebeuconvite-de-aguinaldo-silva-para-voltar-a-atuar-em-o-setimo-guardiao.ghtml

https://gshow.globo.com/novelas/o-setimo-guardiao/noticia/paulo-betti-revive-personagem-emo-setimo-guardiao-e-faz-revelacao-ao-lado-de-luiza-tome.ghtml

https://gshow.globo.com/novelas/o-setimo-guardiao/noticia/luiza-tome-comemora-retorno-descarlet-em-o-setimo-guardiao-bateu-uma-nostalgia.ghtml

https://oplanetatv.clickgratis.com.br/noticias/bastidores/personagens-famosos-de-outrasnovelas-reaparecerao-em-o-setimo-guardiao.html 
https://oplanetatv.clickgratis.com.br/noticias/bastidores/jose-loreto-anuncia-o-setimo-guardiaoem-cena-de-espelho-da-vida.html 


\section{ANEXO B - ENTREVISTA DE GÊNERO FICCIONAL}

Nome:

1. Sobre o que trata a telenovela O Sétimo Guardião?

2. Você lê alguma revista ou acessa sites sobre a telenovela?

3. Você conversa sobre assuntos da telenovela com outras pessoas? Com que frequência? Onde são essas conversas? Offline ou online?

4. Você gosta da telenovela? Por quê?

5. O que você mais gosta na telenovela? Por quê?

6. O que você menos gosta na telenovela? Por quê?

7. Quais são os assuntos mais tratados na telenovela?

8. Existe algum assunto que é tratado na telenovela e que, na sua opinião, não deveria ser tratado?

9. Para você, a telenovela é cômica, dramática, de suspense, romântica ou de ação?

10. A telenovela apresenta cenas ou histórias que para você, são distante ou perto da realidade?

11. A telenovela tem efeitos especiais? Quais?

12. Para você a telenovela é de boa ou má qualidade?

13. Quais os aspectos que mais the chamam a atenção na telenovela?

14. Qual núcleo que você mais gosta da telenovela? Por quê?

15. Como a mulher é retratada na telenovela?

16. Como o homem é retratado na telenovela?

17. Qual personagem da telenovela você considera a típica mulher brasileira?

18. Qual personagem da telenovela você considera o típico homem brasileiro?

19. Você se identifica com algum personagem da telenovela?

20. Você se identifica com algum personagem de classe popular da telenovela? Por quê? Se for classe alta, é a mesma pergunta, mas sobre personagem de classe alta.

21. Conte a trajetória de um personagem de classe popular que the chama a atenção.

22. Quais eram as características deste personagem: família, escola, trabalho e aparência.

23. Conte a trajetória de um personagem de classe alta que the chama a atenção.

24. Quais eram as características deste personagem? Familia, escola, trabalho e aparência.

25. Qual ou quais as características desse personagem que você considera típica de pessoas de classe popular? - assinalar uma opção em cada alternativa.

\begin{tabular}{|l|l|}
\hline ( ) Roupas extravagantes & ( )Roupas discretas \\
\hline ( ) Roupas finas & ( ) Roupas simples \\
\hline ( ) Jeito de falar informal & ( ) Jeito de falar formal \\
\hline ( ) Modos formais à mesa & ( ) Modos informais à mesa \\
\hline ( ) Sexualidade liberada & ( ) Rexualidade conservadora \\
\hline ( ) Emotividade & ( ) Familia não planejada \\
\hline ( ) Planejamento familiar & $\begin{array}{l}\text { ( ) Tendência a pensar no } \\
\text { comunitário }\end{array}$ \\
\hline ( ) Tendência ao individualis mo & ( ) Trabalho manual \\
\hline
\end{tabular}




\begin{tabular}{|c|c|}
\hline $\begin{array}{c}\text { ( ) Submisso na relação com o } \\
\text { homem/mulher }\end{array}$ & $\begin{array}{l}\text { ( ) Igualitário na relação com o } \\
\text { homem/mulher }\end{array}$ \\
\hline
\end{tabular}

26. Qual ou quais as características dele que você considera típica de pessoas de classe alta? - Assinalar uma opção em cada alternativa.

\begin{tabular}{|c|c|}
\hline ( ) Roupas extravagantes & ( )Roupas discretas \\
\hline ( ) Jeito de falar informal & ) Jeito de falar formal \\
\hline ( ) Modos formais à mesa & ( ) Modos informais à mesa \\
\hline ( ) Sexualidade liberada & ( ) Sexualidade conservadora \\
\hline ( ) Emotividade & ( ) Racionalidade \\
\hline ( ) Planejamento familiar & ( ) Família não planejada \\
\hline ( ) Tendência ao individualismo & $\begin{array}{l}\text { ( ) Tendência a pensar no } \\
\text { comunitário }\end{array}$ \\
\hline ( ) Trabalho intelectual & ( ) Trabalho manual \\
\hline $\begin{array}{l}\text { ( ) Submisso na relação com o } \\
\text { homem/mulher }\end{array}$ & $\begin{array}{l}\text { ( ) Igualitária na relação com o } \\
\text { homem/mulher }\end{array}$ \\
\hline ( )Roupas finas & ( )Roupas simples \\
\hline
\end{tabular}

27. Aparecem cenas de sexo? O que você acha delas?

28. Você considera que a telenovela ajuda a entender o que é ser mulher/homem?

29. Você considera que a telenovela ajuda a pensar que mulher/homem você é?

30. Quais as suas telenovelas favoritas? Por quê?

31. Quais as características que você considera específicas da telenovela brasileira? 


\section{ANEXO C - ENTREVISTA DE HISTÓRIA DE VIDA}

\section{Nome:}

\section{Família}

1.Conflitos

2. Educação que recebeu dos pais

Exigências - refeições - televisão - férias - conselhos sobre o trabalho/futuro profissional

3. Personalidade dos pais - passivo, mandão

Liberdade para namorar, viajar sozinho

4. Organização da casa - exemplos - segue uma ordem dada, um planejamento

5. Sua relação com as regras

6. Relação da sua família com pessoas de nível econômico diferente do seu

\section{Família atual}

7.Conflitos

8. Educação que recebeu dos pais

Exigências - refeições - televisão - férias - conselhos sobre o trabalho/futuro profissional

9. Personalidade dos pais - passivo, mandão

Liberdade para namorar, viajar sozinho

10. Organização da casa - exemplos - segue uma ordem dada, um planejamento

11. Sua relação com as regras

12. Relação da sua família com pessoas de nível econômico diferente do seu

\section{Trabalho}

\section{Organização}

14. Dificuldades

15.Relação com as regras

16. Relação com colegas com nível socioeconômicos mais baixo ou mais alto

17. Relação com empregados- quais dificuldades e a que elas se devem?

\section{Escola}

18.Conflitos com colegas - quais conflitos mais comuns - devido raça, classe, aparência

19. Como avalia o desempenho dos professores - autoridade e falta de autoridade; competência

20. Como avalia o seu desempenho - estuda para as provas, estudante dedicado

21. Relação com a disciplina e as regras na escola

\section{Lazer}

22.Preferências por atividades coletivas ou individuais

23.Atividades sindicais que realiza 
24. Desenvolve atividades políticas?

25. Frequenta clubes?

26. Participa de outras formas associativas? Quais, o que faz?

\section{Características pessoais}

27.Como você se define?

28. O que você detesta em alguém? 
ANEXO D - ENTREVISTA DE HISTÓRIA DE VIDA CULTURAL

Cultura letrada

1. Ler

2. Escrever

Cultura oral

3. Conversar

4. Contar

Cultura musical

5. Cantar

6. Ouvir música Cultura artística

7. Assistir

8. Praticar Cultura midiática

9. Entreter

10. Informar

Cultura Tecnológica

11. Computadores

12. Games

13. Objetos eletrônicos

14. Internet Cultura de Lazer

15. Festas

16. Excursões, viagens

17. Clubes

18. Jogos 


\section{ANEXO E - QUESTIONÁRIO DO CONSUMO}

1. Nome:

2. Idade:

3. Endereço:

4. Bairro:

5. Número de pessoas que residem na casa:

6. Profissão:

Onde Trabalha?

7. Profissão do cônjuge:

Onde trabalha?

8. Religião:

9. Responsável pelo sustento da família:

10. Profissão da mãe:

11. Profissão do pai:

12. Profissão dos avós com os quais tem mais proximidade:

13. Filhos? Sim ( ) Não ( ) Quantos:

14. Escolaridade:
( ) Ensino Fundamental Incompleto
( ) Ensino Médio Incompleto
( ) Ensino Fundamental Completo
( ) Ensino Superior Incompleto
( ) Pós-graduação
( ) Ensino Médio Completo
( ) Ensino Superior Completo

15. Escolaridade dos familiares:

\begin{tabular}{|l|l|l|l|l|l|l|}
\hline \multicolumn{1}{|c|}{ Escolaridade } & pai & mãe & irmão & irmã & marido & filho \\
\hline $\begin{array}{l}\text { Ensino Fundamental } \\
\text { Incompleto }\end{array}$ & & & & & & \\
\hline Ensino Fundamental Completo & & & & & & \\
\hline Ensino Médio Incompleto & & & & & & \\
\hline Ensino Médio Completo & & & & & & \\
\hline Ensino Superior Incompleto & & & & & & \\
\hline Ensino Superior Completo & & & & & & \\
\hline Mestrado & & & & & & \\
\hline Doutorado & & & & & & \\
\hline
\end{tabular}

16. Estado Civil: ( ) Solteiro ( ) Casado ( ) Divorciado ( ) Viúvo ( ) União estável

17. Qual sua atividade de lazer favorita?

18. Frequência das atividades semanais no tempo livre

\begin{tabular}{|l|l|l|l|}
\hline \multicolumn{1}{|c|}{ Atividade } & Nunca & As vezes & Sempre \\
\hline Visitas parentes & & & \\
\hline Visitas amigos & & & \\
\hline Esporte & & & \\
\hline
\end{tabular}




\begin{tabular}{|l|l|l|l|}
\hline Bar & & & \\
\hline Clube & & & \\
\hline
\end{tabular}

19. Quantos aparelhos de comunicação tem na casa?
( ) Televisão
( ) Computador
( ) Telefone fixo
( ) Telefone celular
( ) Rádio

20. Qual o número de horas dedicadas à televisão?
( ) menos de $1 \mathrm{~h}$ ( ) entre $1 \mathrm{~h}$ e $2 \mathrm{~h}$ ( ) entre $2 \mathrm{~h}$ e $3 \mathrm{~h}$ ( ) entre $3 \mathrm{~h}$ e $4 \mathrm{~h}$ ( ) mais de $4 \mathrm{~h}$

21. Que companhia costuma ter quando assiste TV?
( ) família
( ) sozinho
( ) namorado(a), noivo(a)
( ) amigos

22. Qual o seu canal de televisão favorito? Por quê?

23. Qual seu programa favorito? Por quê?

24. Comparando a televisão com o livro, qual o que mais the agrada? Por quê?

25. Comparando a televisão com o teatro, qual o que mais lhe agrada? Por quê?

26. Comparando a televisão com o cinema, qual o que mais the agrada? Por quê?

27. Comparando a televisão com o Youtube, qual o que mais the agrada? Por quê?

28. Comparando a televisão com as redes sociais, qual o que mais the agrada? Quala rede social você está se referindo? Por quê?

29. Comparando a televisão com o Netflix, qual o que mais the agrada? Por quê?

30. Cite um livro que você esteja lendo no momento?

31. Cite uma peça de teatro que você tenha visto.

32. Cite um filme que você viu recentemente?

33. Qual seu sonho de consumo?

34. A televisão apresentou alguma situação a qual você quisesse fazer ou viver?

35. A televisão apresentou alguma coisa que você gostaria de ter? Em qual programa?

36. Qual sua forma preferida de lazer?

37. Três formatos de programa que mais gosta, em ordem de preferência?
( ) desenho ( ) documentário ( ) esporte ( ) entrevista
( ) filme ( ) humorístico ( ) auditório ( ) musical
( ) noticiário ( ) telenovela ( ) talk-show ( ) seriado
( ) reality show

38. Quais são os três canais de televisão mais assistidos:

( ) Globo
( ) MTV
( ) People and Arts
( ) Warner
( ) Telecines
( ) Band

( ) SBT
( ) Cartoon
( ) Sony
( ) National Geographic
( ) Outros quais:
( ) Record TV
( ) TNT

( ) Discovery

( ) Globo News

( ) Universal

( ) GNT

( ) Rede TV!

( ) Record TV 
39. Nome do jornal que costuma ler:

40. Frequência:

( ) diariamente

( ) de 2 a 3 vezes por semana

( ) 1 vez por semana

( ) fim de semana

( ) quinzenalmente

( ) mensalmente (1 x por mês)

( ) anualmente (1 x por mês)

41. Títulos das revistas que costuma ler:

42. Frequência da leitura de revistas

( ) diariamente

( ) de 2 a 3 vezes por semana

( )1 vez por semana

( ) fim de semana

( ) quinzenalmente

( ) mensalmente (1 x por mês)

( ) anualmente

43. Quantos livros extraescolares lê por ano?

44. Títulos ou autores que lembra:

45. Frequência com que lê livros?

( ) diariamente

( ) de 2 a 3 vezes por semana

( )1 vez por semana

( ) fim de semana

( ) quinzenalmente

( ) mensalmente (1 x por mês)

( ) anualmente

46. Frequência com que usa o computador:

( ) diariamente

( ) de 2 a 3 vezes por semana

( )1 vez por semana

( ) fim-de-semana

( ) quinzenalmente

( ) mensalmente ( 1 x por mês)

( ) anualmente

47. Quais emissoras de rádio você escuta:

48. Frequência:

( ) diariamente

( ) de 2 a 3 vezes por semana

( ) 1 vez por semana

( ) fim de semana

( ) quinzenalmente 
( ) mensalmente ( 1 x por mês)

( ) anualmente

49. Diga três estilos musicais preferidos
( ) axé
( ) clássica
( ) dance
( ) emo
( ) forró
( ) funk
( ) pagode
( ) samba
( ) sertanejo
) regionalista
( ) rap
( ) punk
( ) pop rock nacional
( ) pop rock internacional
( ) heavy metal
( ) hardcore
( ) reggae
( ) techno/eletrônica

50. Títulos de filmes que lembra:

51. Títulos de telenovelas e ou séries que você lembra:

52. Nome de atores que lembra:

53. Frequência com que assiste filmes:

( ) diariamente

( ) de 2 a 3 vezes por semana

( )1 vez por semana

( ) fim de semana

( ) quinzenalmente

( ) mensalmente (1 x por mês)

( ) anualmente

54. Você costuma assistir a telenovelas?
( ) Não
( ) $\operatorname{Sim}$
Quais?

55. O que você mais gosta nas telenovelas?

56. O que você menos gosta?

57. Frequência com que assiste telenovela/séries:

( ) diariamente

( ) de 2 a 3 vezes por semana

( )1 vez por semana

( ) fim de semana

( ) quinzenalmente

( ) mensalmente (1 x por mês)

( ) anualmente

58. Atividades de maior uso da internet em ordem decrescente (1/maior a 6/menor)

( ) e-mail

( ) trabalho

( ) Facebook 
( ) Instagram

( ) Twitter

( ) Youtube

( ) música

( ) leitura de jornais

( ) jogos

( ) baixar filmes

( ) consulta sites para obter conhecimento ou serviços

( ) Netflix e outros do tipo

59. Local de acesso à internet

( ) trabalho

( ) casa

( ) locais públicos Quais:

( ) escola

( ) casa de amigos

( ) celular

60. Tipo de informação buscada na internet

( ) notícias

( ) trabalho de aula

( ) cinema, shows

( ) bastidores de telenovelas, séries e filmes

( ) festas, bares, baladas

( ) empregos

( ) vida de celebridades

( ) cultural - museus, pesquisa sobre países, viagens

( ) humor

( ) relações sociais

61. Frequência a espetáculos artísticos:

\begin{tabular}{|l|l|l|l|l|l|l|}
\hline Espetáculo & $\begin{array}{c}1 \text { vez por } \\
\text { semana }\end{array}$ & mensal & quinzenal & anual & $\begin{array}{c}1 \text { vez ou 2 } \\
\mathrm{p} / \text { ano }\end{array}$ & nunca \\
\hline Teatro & & & & & & \\
\hline $\begin{array}{l}\text { Balé; } \\
\text { Dança }\end{array}$ & & & & & & \\
\hline $\begin{array}{l}\text { Exposições } \\
\text { de artes }\end{array}$ & & & & & & \\
\hline Shows & & & & & & \\
\hline Outro -qual & & & & & & \\
\hline
\end{tabular}

62. Cite uma viagem inesquecível?

63. Cite um dia inesquecível?

64. Diga um objeto que adora ter?

65. O que você mais gostaria de comprar hoje? 
